Prepared in cooperation with the Utah Division of Water Rights, City of Moab, Grand and San Juan Counties, Grand Water and Sewer Service Agency, Utah School and Institutional Trust Lands Administration, The Nature Conservancy, Utah Division of Wildlife Resources, Living Rivers, San Juan Spanish Valley Special Service District, U.S. Bureau of Land Management, and U.S. Forest Service

\title{
Evaluation of Groundwater Resources in the Spanish Valley Watershed, Grand and San Juan Counties, Utah
}

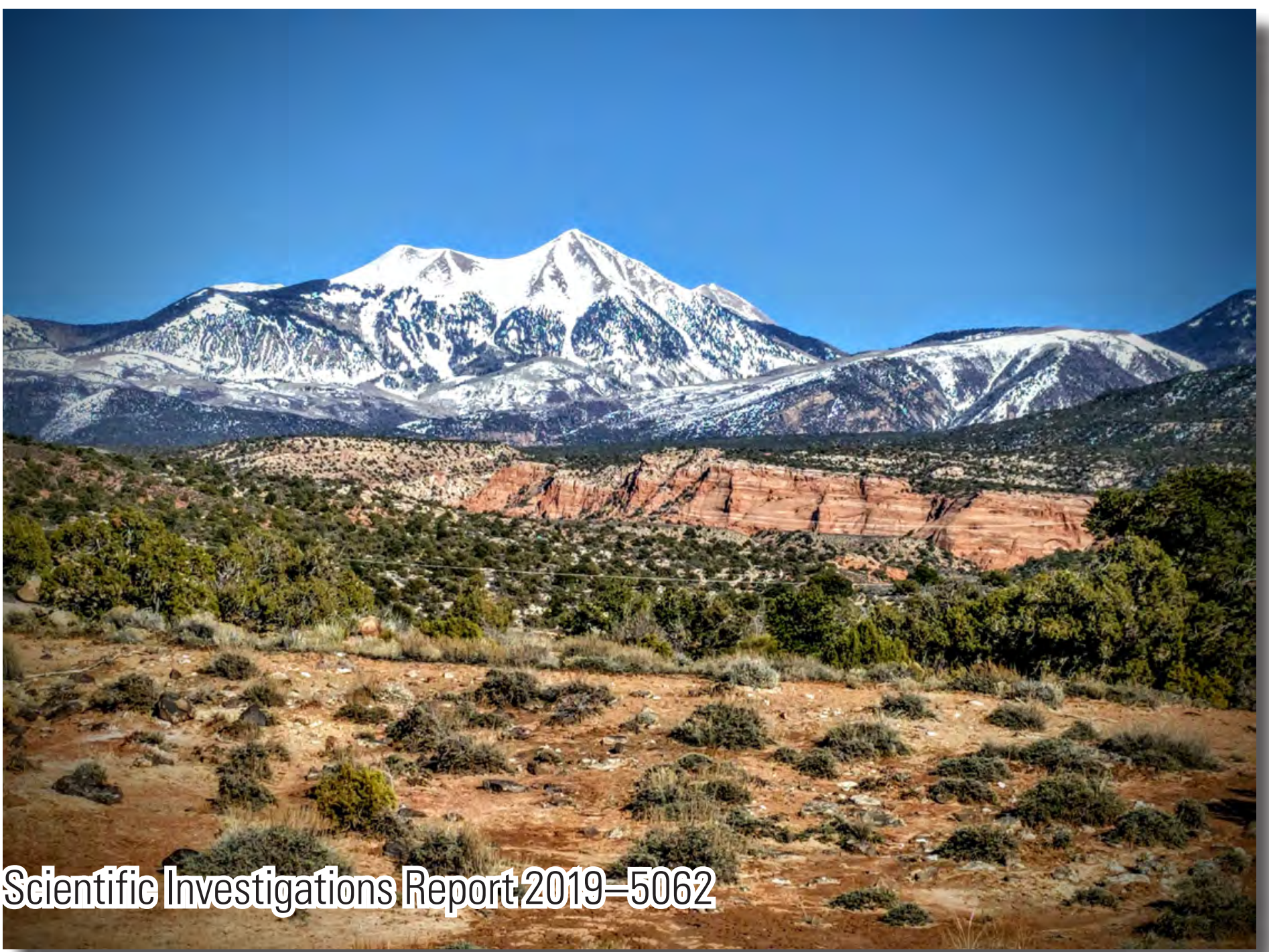

U.S. Department of the Interior U.S. Geological Survey 
Front cover: Spanish Valley looking east towards the La Sal Mountains. Photograph by Philip Gardner, U.S. Geological Survey, February 29, 2016.

Back cover: Spanish Valley near Ken's Lake looking east at the Sheley Tunnel. Photograph by Melissa Masbruch, U.S. Geological Survey, September 27, 2011. 


\section{Evaluation of Groundwater Resources in the Spanish Valley Watershed, Grand and San Juan Counties, Utah}

By Melissa D. Masbruch, Philip M. Gardner, Nora C. Nelson, Victor M. Heilweil, John E. Solder, Michael D. Hess, Timothy S. McKinney, Martin A. Briggs, and D. Kip Solomon

Prepared in cooperation with the Utah Division of Water Rights, City of Moab, Grand and San Juan Counties, Grand Water and Sewer Service Agency, Utah School and Institutional Trust Lands Administration, The Nature Conservancy, Utah Division of Wildlife Resources, Living Rivers, San Juan Spanish Valley Special Service District, U.S. Bureau of Land Management, and U.S. Forest Service

Scientific Investigations Report 2019-5062 


\title{
U.S. Department of the Interior DAVID BERNHARDT, Secretary
}

\author{
U.S. Geological Survey \\ James F. Reilly II, Director
}

U.S. Geological Survey, Reston, Virginia: 2019

For more information on the USGS - the Federal source for science about the Earth, its natural and living resources, natural hazards, and the environment-visit https://www.usgs.gov or call 1-888-ASK-USGS.

For an overview of USGS information products, including maps, imagery, and publications, visit https://store.usgs.gov.

Any use of trade, firm, or product names is for descriptive purposes only and does not imply endorsement by the U.S. Government.

Although this information product, for the most part, is in the public domain, it also may contain copyrighted materials as noted in the text. Permission to reproduce copyrighted items must be secured from the copyright owner.

Suggested citation:

Masbruch, M.D., Gardner, P.M., Nelson, N.C., Heilweil, V.M., Solder, J.E., Hess, M.D., McKinney, T.S.,

Briggs, M.A., and Solomon, D.K., 2019, Evaluation of groundwater resources in the Spanish Valley Watershed, Grand and San Juan Counties, Utah: U.S. Geological Survey Scientific Investigations Report 2019-5062, 86 p., https://doi.org/10.3133/sir20195062. 


\section{Acknowledgments}

A special thank you to Marc Stilson from the Utah Division of Water Rights for organizing numerous meetings between the U.S. Geological Survey and all cooperators on this report. 


\section{Contents}

Abstract

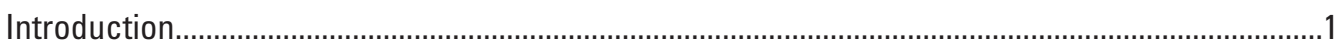

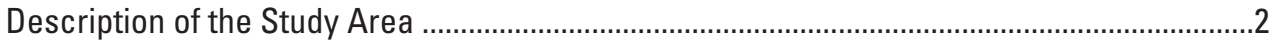

Purpose and Objectives.................................................................................................

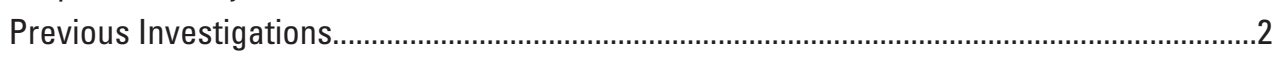

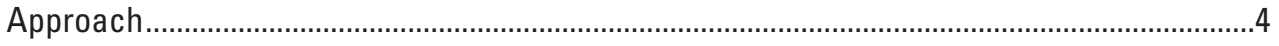

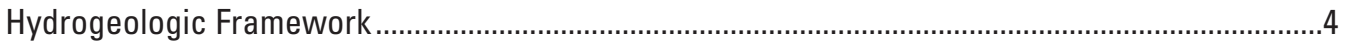

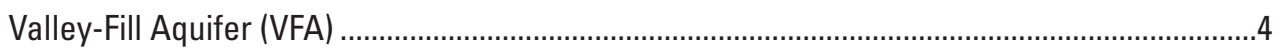

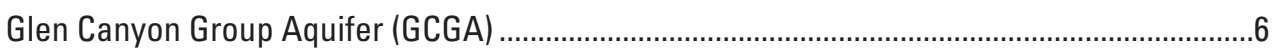

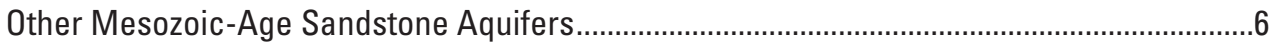

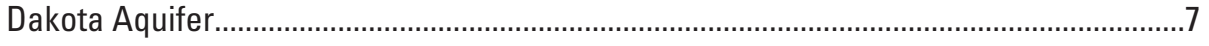

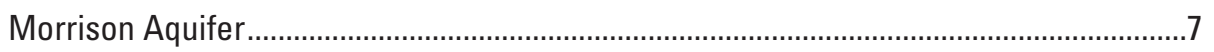

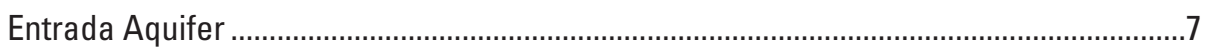

Sandstone Net-Infiltration Methods and Mapping ..................................................................

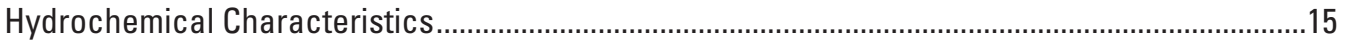

Environmental Tracer Geochemistry Background ...........................................................15

Stable Isotopes of Oxygen and Hydrogen .............................................................15

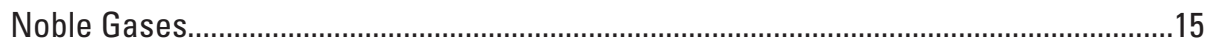

Tritium and Helium Isotopes................................................................................16

Chlorofluorocarbons and Sulfur Hexaflouride ..............................................................17

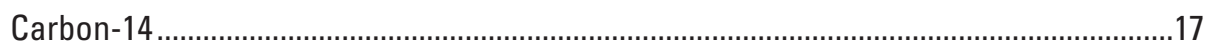

Vadose-Zone Environmental Tracers ............................................................................17

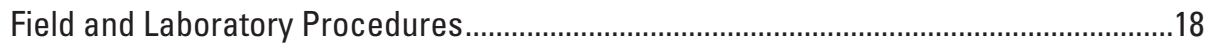

Chloride and Bromide ................................................................................................19

Tritium and Moisture Content ..................................................................................19

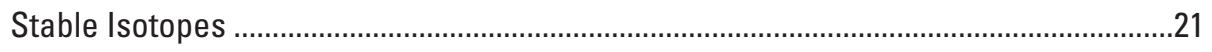

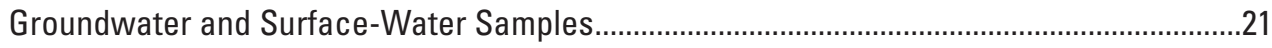

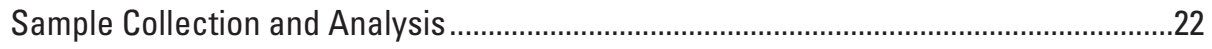

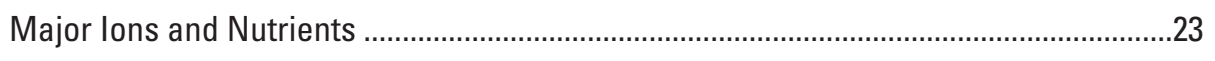

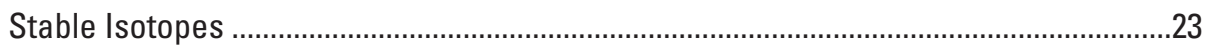

Dissolved Noble Gases ..........................................................................................

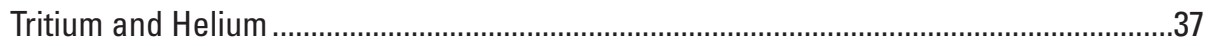

Chlorofluorocarbons and Sulfur Hexafluoride ...............................................................4

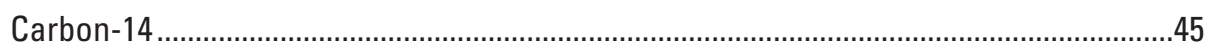

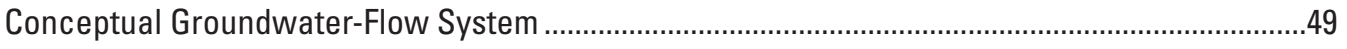

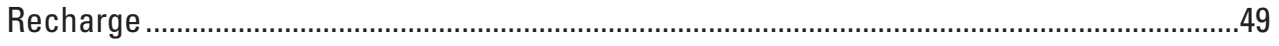

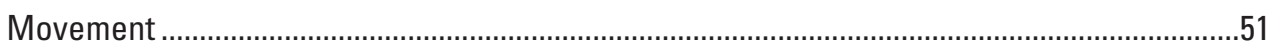

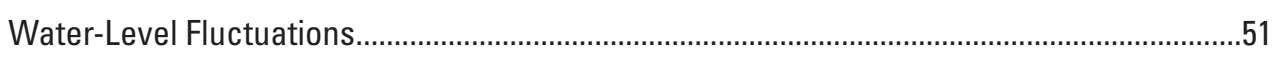

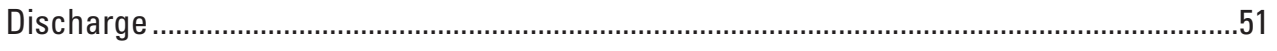

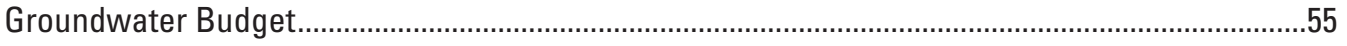

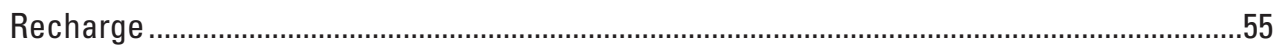

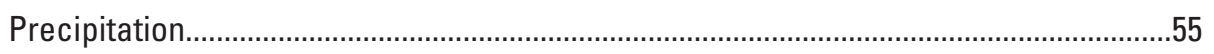

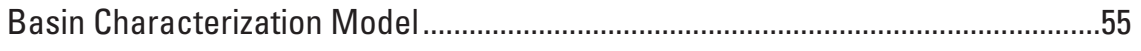

Sandstone Net-Infiltration Mapping.......................................................................56 
Unconsumed Irrigation From Well Withdrawals ..........................................................56

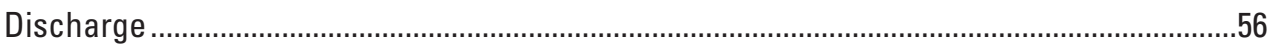

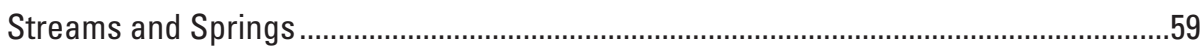

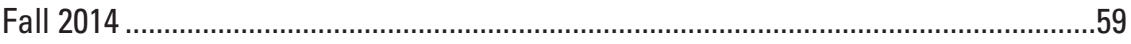

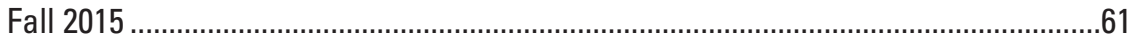

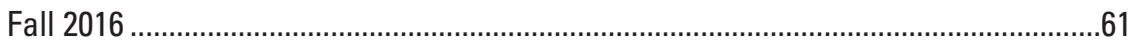

Summary of Base-Flow Groundwater Discharge Measurements ...........................64

Springs and Well Withdrawals for Culinary Use ..........................................................64

Well Withdrawals for Irrigation ...................................................................................64

Discharge as Subsurface Outflow to the Colorado River ................................................64

Geophysical Characterization of Shallow Groundwater Salinity ............................66

Drilling and Well Installation.............................................................................69

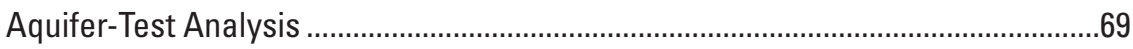

Estimates of Subsurface Outflow........................................................................72

Hydraulic-Gradient (Darcy-Flux) Method .....................................................72

Age-Gradient Method ………………..........................................................

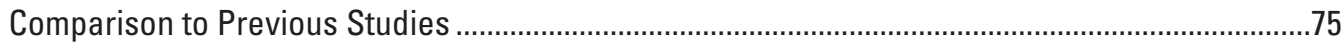

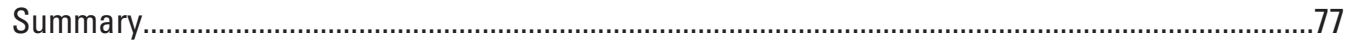

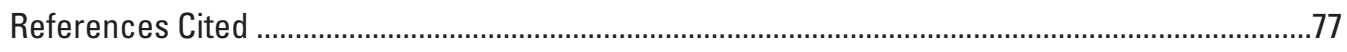

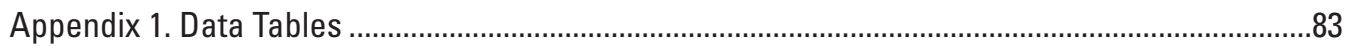

\section{Figures}

1. Map showing the location of the Spanish Valley study area, and the MoabSpanish Valley watershed, Grand and San Juan Counties, Utah.

2. Map showing soil coarseness for soils covering the Glen Canyon Group and Entrada Sandstone areas in the Moab-Spanish Valley watershed part of the Spanish Valley study area, Utah.

3. Map showing topographic slope of soil-covered areas of the Glen Canyon Group and Entrada Sandstone in the Moab-Spanish Valley watershed part of the Spanish Valley study area, Utah

4. Map showing downgradient influence flow paths on soils covering the Glen Canyon Group and Entrada Sandstone areas in the Moab-Spanish Valley watershed part of the Spanish Valley study area, Utah.

5. Map showing distribution of average annual precipitation on the Glen Canyon Group and Entrada Sandstone areas in the Moab-Spanish Valley watershed part of the Spanish Valley study area, Utah

6. Map showing distribution of estimated conceptual net-infiltration rates on the Glen Canyon Group and Entrada Sandstone areas in the Moab-Spanish Valley watershed part of the study area, and locations of borehole core sites used to calculate vadose-zone net-infiltration rates on the sandstone areas, Spanish Valley study area, Utah.

7. Graphs showing vadose-zone concentration profiles for chloride and tritium in leachate samples from cores collected at four borehole sites along Sand Flats Road, Spanish Valley study area, Utah

8. Trilinear diagram showing major-ion composition of selected samples from wells, springs, and one stream in the Spanish Valley study area, Utah. .26

9. Graph showing stable-isotope values of water samples collected during this study and by Nelson (2017) in the Spanish Valley study area, Utah. 
10. Graphs showing stable-isotope values of surface-water samples collected in Mill Creek and Pack Creek compared to the range of values observed in groundwater samples from the Glen Canyon Group aquifer and valley-fill aquifer in the Spanish Valley study area, Utah

11. Graph showing noble-gas recharge temperatures for groundwater compared to valley water-table temperatures in the Spanish Valley study area, Utah.

12. Map showing tritium-helium based age categories of selected samples from wells and springs in the Spanish Valley study area, Utah

13. Graph showing concentrations of chlorofluorocarbon-11 compared to chlorofluorocarbon-12 in selected groundwater samples from the Spanish Valley study area, Utah.

14. Graph showing concentrations of chlorofluorocarbon-12 compared to tritium in selected groundwater samples from the Spanish Valley study area, Utah

15. Graph showing concentrations of sulfur hexafluoride compared to tritium in selected groundwater samples from the Spanish Valley study area, Utah

16. Map showing concentrations of sulfur hexafluoride in groundwater samples from the Spanish Valley study area, Utah.

17. Graph showing carbon-14 activity compared to $\delta^{13} \mathrm{C}$ for groundwater samples from the Spanish Valley study area, Utah.

18. Schematic diagram showing conceptualization of the groundwater flow system and budget components for the Spanish Valley study area, Utah

19. Map showing location of wells in the study area that have long-term annual water-level records in the Spanish Valley study area, Utah

20. Graphs showing cumulative departure from average annual precipitation at Moab and annual water-level hydrographs in wells with long-term water-level records in the Spanish Valley study area, Utah.

21. Map showing the distribution of average annual in-place recharge estimated by the Basin Characterization Model in the Moab-Spanish Valley watershed part of the Spanish Valley study area, Utah.

22. Map showing the distribution of average annual runoff estimated by the Basin Characterization Model in the Moab-Spanish Valley watershed part of the Spanish Valley study area, Utah..

23. Map showing location of groundwater and stream discharge measurements made during fall 2014 in the Spanish Valley study area, Utah.

24. Map showing location of stream and spring discharge measurements made during fall 2015 in the Spanish Valley study area, Utah.

25. Map showing location of stream and spring discharge measurements made during fall 2016 in the Spanish Valley study area, Utah.

26. Chart showing groundwater discharge in the Spanish Valley study area, Utah .............65

27. Map showing mean apparent electrical conductivity obtained by frequencydomain electromagnetic survey and vertical electrical sounding points collected on and near the Colorado River in the Matheson Wetlands Preserve, Moab, Utah.......67

28. Graph showing the log of electrical conductivity with depth and vertical sounding points along line $A-A^{\prime}$

29. Graph showing results of modeled vertical electrical sounding data.

30. Map showing the locations of 12 new observation wells installed in the Matheson Wetlands Preserve, Spanish Valley study area, Utah .70

31. Graph showing lithologic logs for the new observation wells installed in the Matheson Wetlands Preserve, Spanish Valley study area, Utah. 
32. Graph showing transmissivity results from aquifer tests in the Matheson

Wetlands Preserve, Spanish Valley study area, Utah

33. Map showing the flownet used to calculate discharge to the Colorado River through the Matheson Wetlands Preserve using the hydraulic-gradient method, Spanish Valley study area, Utah.

34. Map showing the tritium/helium-3 and chlorofluorocarbon-12 apparent ages from valley-fill aquifer samples and the sample clusters used to calculate discharge to the Colorado River through the Matheson Wetlands Preserve using the agegradient method, Spanish Valley study area, Utah

\section{Tables}

1. Principal aquifers and confining units within the Spanish Valley study area, Utah..........5

2. Coarseness of soil types covering the Glen Canyon Group and Entrada Sandstone areas in the Moab-Spanish Valley watershed part of the Spanish Valley study area, Utah.

3. Summary of environmental tracers collected from vadose-zone borehole core samples from the Navajo Sandstone outcrop part of the Spanish Valley study area, Utah.

4. Field-measured water-quality parameters, stable isotopes of water, and dissolved-ion concentrations measured during the present study in selected samples from wells, springs, and streams in the Spanish Valley study area, Utah

5. Historical field-measured water-quality parameters and dissolved-ion concentrations in selected samples from wells, springs, and streams in the Spanish Valley study area, Utah.

6. Field-measured water-quality parameters, stable isotopes of water, and dissolved-ion concentrations of selected groundwater samples measured by Nelson (2017) in the lower part of the Spanish Valley study area, Utah

7. Field-measured water-quality parameters and stable isotopes of water from selected stream sites in the Spanish Valley study area, Utah

8. Dissolved noble-gas concentrations and related noble-gas temperature data for groundwater sampled in the Spanish Valley study area, Utah.

9. Stable- and radio-isotope data and industrial gas concentrations used to estimate ages of groundwater sampled in the Spanish Valley study area, Utah

10. Stable- and radio-isotope data and industrial gas concentrations measured by Nelson (2017) used to estimate ages of groundwater sampled in the Spanish Valley study area, Utah.

11. Annual 2014, 2015, and 2016, and average annual groundwater budgets for the Moab-Spanish Valley watershed part of the Spanish Valley study area, Utah

12. Summary of total measured base-flow groundwater discharge in the Spanish Valley study area, Utah

13. Summary of well withdrawals for irrigated crops in the Spanish Valley study area, Utah.

14. Summary of transmissivity results from aquifer tests in the Matheson Wetlands Preserve, Spanish Valley study area, Utah.

1-1. Selected attributes of groundwater, spring, and surface-water sites sampled in the Spanish Valley study area, Utah.

1-2. Selected attributes of wells and water levels used in constructing the waterlevel surface map for the Spanish Valley study area, Utah 


\section{Plates}

Available for downloading from https://doi.org/10.3133/sir20195062.

1. Surficial extent and cross sections of hydrogeologic units for selected locations in the Spanish Valley study area, Utah

2. Stiff diagrams showing major-ion composition from hydrogeologic units in the Spanish Valley study area, Utah

3. Water-level surface map and general direction of groundwater movement in the Spanish Valley study area, Utah

\section{Conversion Factors}

U.S. customary units to International System of Units

\begin{tabular}{|c|c|c|}
\hline Multiply & By & To obtain \\
\hline \multicolumn{3}{|c|}{ Length } \\
\hline inch (in.) & 2.54 & centimeter $(\mathrm{cm})$ \\
\hline inch (in.) & 25.4 & millimeter $(\mathrm{mm})$ \\
\hline foot (ft) & 0.3048 & meter $(\mathrm{m})$ \\
\hline mile (mi) & 1.609 & kilometer (km) \\
\hline \multicolumn{3}{|c|}{ Area } \\
\hline acre & 4,047 & square meter $\left(\mathrm{m}^{2}\right)$ \\
\hline acre & 0.4047 & hectare (ha) \\
\hline square foot $\left(\mathrm{ft}^{2}\right)$ & 0.09290 & square meter $\left(\mathrm{m}^{2}\right)$ \\
\hline square inch $\left(\mathrm{in}^{2}\right)$ & 6.452 & square centimeter $\left(\mathrm{cm}^{2}\right)$ \\
\hline square mile $\left(\mathrm{mi}^{2}\right)$ & 2.590 & square kilometer $\left(\mathrm{km}^{2}\right)$ \\
\hline \multicolumn{3}{|c|}{ Volume } \\
\hline ounce, fluid (fl. oz) & 0.02957 & liter $(\mathrm{L})$ \\
\hline pint (pt) & 0.4732 & liter (L) \\
\hline quart (qt) & 0.9464 & liter (L) \\
\hline gallon (gal) & 3.785 & liter $(\mathrm{L})$ \\
\hline gallon (gal) & 0.003785 & cubic meter $\left(\mathrm{m}^{3}\right)$ \\
\hline cubic inch $\left(\right.$ in $\left.^{2}\right)$ & 0.01639 & liter (L) \\
\hline cubic foot $\left(\mathrm{ft}^{3}\right)$ & 0.02832 & cubic meter $\left(\mathrm{m}^{3}\right)$ \\
\hline acre-foot (acre-ft) & 1,233 & cubic meter $\left(\mathrm{m}^{3}\right)$ \\
\hline \multicolumn{3}{|c|}{ Flow rate } \\
\hline acre-foot per day (acre-ft/d) & 0.01427 & cubic meter per second $\left(\mathrm{m}^{3} / \mathrm{s}\right)$ \\
\hline acre-foot per year (acre-ft/yr) & 1,233 & cubic meter per year $\left(\mathrm{m}^{3} / \mathrm{yr}\right)$ \\
\hline foot per second (ft/s) & 0.3048 & meter per second $(\mathrm{m} / \mathrm{s})$ \\
\hline foot per minute (ft/min) & 0.3048 & meter per minute $(\mathrm{m} / \mathrm{min})$ \\
\hline foot per hour (ft/h) & 0.3048 & meter per hour $(\mathrm{m} / \mathrm{h})$ \\
\hline foot per day (ft/d) & 0.3048 & meter per day $(\mathrm{m} / \mathrm{d})$ \\
\hline foot per year (ft/yr) & 0.3048 & meter per year (m/yr) \\
\hline cubic foot per second $\left(\mathrm{ft}^{3} / \mathrm{s}\right)$ & 0.02832 & cubic meter per second $\left(\mathrm{m}^{3} / \mathrm{s}\right)$ \\
\hline
\end{tabular}




\begin{tabular}{|c|c|c|}
\hline Multiply & By & To obtain \\
\hline \multicolumn{3}{|c|}{ Flow rate-Continued } \\
\hline cubic foot per day $\left(\mathrm{ft}^{3} / \mathrm{d}\right)$ & 0.02832 & cubic meter per day $\left(\mathrm{m}^{3} / \mathrm{d}\right)$ \\
\hline gallon per minute (gal/min) & 0.06309 & liter per second $(\mathrm{L} / \mathrm{s})$ \\
\hline gallon per day (gal/d) & 0.003785 & cubic meter per day $\left(\mathrm{m}^{3} / \mathrm{d}\right)$ \\
\hline inch per year (in/yr) & 25.4 & millimeter per year (mm/yr) \\
\hline mile per hour (mi/h) & 1.609 & kilometer per hour $(\mathrm{km} / \mathrm{h})$ \\
\hline \multicolumn{3}{|c|}{ Pressure } \\
\hline atmosphere, standard (atm) & 101.3 & kilopascal $(\mathrm{kPa})$ \\
\hline \multicolumn{3}{|c|}{ Density } \\
\hline pound per cubic foot $\left(\mathrm{lb} / \mathrm{ft}^{3}\right)$ & 16.02 & kilogram per cubic meter $\left(\mathrm{kg} / \mathrm{m}^{3}\right)$ \\
\hline pound per cubic foot $\left(\mathrm{lb} / \mathrm{ft}^{3}\right)$ & 0.01602 & gram per cubic centimeter $\left(\mathrm{g} / \mathrm{cm}^{3}\right)$ \\
\hline \multicolumn{3}{|c|}{ Specific capacity } \\
\hline gallon per minute per foot ([gal/min]/ft) & 0.2070 & liter per second per meter $([\mathrm{L} / \mathrm{s}] / \mathrm{m})$ \\
\hline \multicolumn{3}{|c|}{ Hydraulic conductivity } \\
\hline foot per day (ft/d) & 0.3048 & meter per day $(\mathrm{m} / \mathrm{d})$ \\
\hline \multicolumn{3}{|c|}{ Hydraulic gradient } \\
\hline foot per mile (ft/mi) & 0.1894 & meter per kilometer $(\mathrm{m} / \mathrm{km})$ \\
\hline \multicolumn{3}{|c|}{ Transmissivity } \\
\hline foot squared per day $\left(\mathrm{ft}^{2} / \mathrm{d}\right)$ & 0.09290 & meter squared per day $\left(\mathrm{m}^{2} / \mathrm{d}\right)$ \\
\hline
\end{tabular}

Temperature in degrees Celsius $\left({ }^{\circ} \mathrm{C}\right)$ may be converted to degrees Fahrenheit $\left({ }^{\circ} \mathrm{F}\right)$ as

$$
{ }^{\circ} \mathrm{F}=\left(1.8 \times{ }^{\circ} \mathrm{C}\right)+32 \text {. }
$$

Temperature in degrees Fahrenheit $\left({ }^{\circ} \mathrm{F}\right)$ may be converted to degrees Celsius $\left({ }^{\circ} \mathrm{C}\right)$ as

$$
{ }^{\circ} \mathrm{C}=\left({ }^{\circ} \mathrm{F}-32\right) / 1.8 .
$$

\section{Datum}

Vertical coordinate information is referenced to the North American Vertical Datum of 1988 (NAVD 88).

Horizontal coordinate information is referenced to the North American Datum of 1983 (NAD 83).

Altitude, as used in this report, refers to distance above the vertical datum.

\section{Supplemental Information}

Transmissivity: The standard unit for transmissivity is cubic foot per day per square foot times foot of aquifer thickness $\left(\left[\mathrm{ft}^{3} / \mathrm{d}\right] / \mathrm{ft}^{2}\right) \mathrm{ft}$. In this report, the mathematically reduced form, foot squared per day $\left(\mathrm{ft}^{2} / \mathrm{d}\right)$, is used for convenience.

Specific conductance is given in microsiemens per centimeter at 25 degrees Celsius $(\mu \mathrm{S} / \mathrm{cm}$ at $\left.25^{\circ} \mathrm{C}\right)$. 
Concentrations of chemical constituents in water are given in either milligrams per liter (mg/L) or micrograms per liter $(\mu \mathrm{g} / \mathrm{L})$.

Activities for radioactive constituents in water are given in picocuries per liter ( $\mathrm{pCi} / \mathrm{L}$ ).

Results for measurements of stable isotopes of an element (with symbol E) in water, solids, and dissolved constituents commonly are expressed as the relative difference in the ratio of the number of the less abundant isotope $(\mathrm{I} E)$ to the number of the more abundant isotope of a sample with respect to a measurement standard.

\section{Abbreviations}

$\begin{array}{ll}\text { BCM } & \text { Basin Characterization Model } \\ \text { CFCs } & \text { chlorofluorocarbons } \\ \text { DEM } & \text { Digital Elevation Model } \\ \text { DIC } & \text { Dissolved inorganic carbon } \\ \text { EPA } & \text { U.S. Environmental Protection Agency } \\ \text { FDEM } & \text { frequency-domain electromagnetic } \\ \text { GCGA } & \text { Glen Canyon Group aquifer } \\ \text { GIS } & \text { Geographic Information System } \\ \text { GWSSA } & \text { Grand Water and Sewer Service Agency } \\ \text { NWQL } & \text { National Water Quality Laboratory } \\ \text { PCD } & \text { Pack Creek drainage } \\ \text { pmC } & \text { percent modern carbon } \\ \text { SSURGO } & \text { Soil Survey Geographic Database } \\ \text { TDTP } & \text { tritium depth to peak } \\ \text { USGS } & \text { U.S. Geological Survey } \\ \text { VES } & \text { vertical electrical soundings } \\ \text { VFA } & \text { valley-fill aquifer }\end{array}$




\title{
Evaluation of Groundwater Resources in the Spanish Valley Watershed, Grand and San Juan Counties, Utah
}

\author{
By Melissa D. Masbruch, Philip M. Gardner, Nora C. Nelson, Victor M. Heilweil, John E. Solder, Michael D. \\ Hess, Timothy S. McKinney, Martin A. Briggs, and D. Kip Solomon'
}

\section{Abstract}

Groundwater resources in the Spanish Valley watershed in southern Utah were quantified for the first time since the early 1970s. The primary objectives of this study were (1) to better understand sources of recharge to, groundwater flow directions within, and discharge points for both the valley-fill and Glen Canyon Group aquifers (VFA and GCGA), and (2) to quantify groundwater budget components of the combined VFA and GCGA, including both recharge and discharge. Based on both groundwater chemistry (stable isotopes, major ions, and noble gases) and environmental tracers in vadosezone pore water of the Navajo Sandstone outcrop along Sand Flats Road, most recharge to the GCGA occurs high in the La Sal Mountains, and not on the sandstone outcrop area. The same groundwater chemistry and environmental tracer evidence from the saturated zone indicates that Pack Creek, rather than GCGA groundwater, is the primary source of recharge to the VFA. Groundwater recharge in the study area occurs mostly from infiltration of precipitation (in the form of snowmelt) at high altitudes. Additional recharge occurs from the infiltration of runoff along losing reaches of stream channels, or as unconsumed surface-water and groundwater irrigation. Average annual recharge to the Moab-Spanish Valley watershed part of the Spanish Valley study area was estimated to be between 9,550 and 30,000 acre-feet. Based on water-levels collected in the current study, groundwater in both the GCGA and the VFA generally moves downgradient parallel to the topographic slope of the watershed towards the Colorado River. Groundwater discharge measurements, and hydraulic-flux estimates at the lower end of Spanish Valley, provide a more robust estimate of the groundwater budget than evaluating recharge. The primary base-flow discharge components in the study area include groundwater discharge to gaining reaches of streams, groundwater discharge to springs, and well withdrawals. Based on 3 years of measurements (2014-16) and hydraulic-flux calculations at the lower end of Spanish Valley, total groundwater discharge was estimated to be 14,000 to 16,000 acre-feet per year (acre-ft/yr) for the entire watershed, or 13,000 to 15,000 acre-ft/yr, excluding the watershed areas of Grandstaff (formerly Negro Bill) and Ice Box Canyons (compared to the 1971 Sumsion estimate of 22,000 acre-ft/yr). The primary difference is this study's estimate of subsurface outflow to the Colorado River of only 300 to 1,000 acre-ft/yr, compared to $11,000 \mathrm{acre}-\mathrm{ft} / \mathrm{yr}$ estimated by Sumsion. Because the study period (2014-16) experienced above average precipitation for 2 of the 3 years, the discharge estimates may be slightly higher than long-term average annual discharge from the groundwater system.

\section{Introduction}

Future growth in the Spanish Valley, Utah, area is dependent on adequate water resources. With surface waters fully appropriated, future development must be met with additional groundwater development. There have been no regional efforts to refine the major groundwater budget components within the Spanish Valley area since the 1970s. With an arid climate and limited recharge, further study is needed to better understand the groundwater system and its boundaries, along with improved estimates of the most important groundwater budget components. This information will be useful to local and State water managers in evaluating how much additional development can be sustained by the aquifer system and for developing a groundwater management plan.

\footnotetext{
${ }^{1}$ University of Utah
} 


\section{Description of the Study Area}

The Spanish Valley study area, located in southeastern Utah, covers about 208 square miles ( $\mathrm{mi}^{2}$; fig. 1). Within the Spanish Valley study area, the Moab and Spanish valleys (hereafter referred to as Moab-Spanish Valley) encompass about $23 \mathrm{mi}^{2}$ (Steiger and Susong, 1997) and are located within a northwest-trending, elongate trough formed by the collapse of the Moab salt-cored anticline (Lowe and others, 2007); they are not topographically or geologically separable (Sumsion, 1971). In previous studies, the Spanish Valley area, which included both valleys, was defined as stopping at the topographic divide (or watershed boundary) between the Kane Springs Creek watershed and southern Spanish Valley. The current study area extended slightly southward of the topographic divide towards Kane Springs Creek (fig. 1) for the purpose of identifying the location of any potential groundwater divides between the Moab-Spanish Valley and Kane Springs Creek watersheds. The population of the Spanish Valley study area is about 5,500 (U.S. Census Bureau, 2010), with the majority living in the city of Moab.

Altitudes within the study area range from 3,950 feet (ft) at the Colorado River near Moab, to 12,645 ft at Mount Mellenthin in the La Sal Mountains. Because of the large range in altitude, the Spanish Valley area encompasses a wide variety of climatic conditions. Mean annual precipitation ranges from less than 9 inches (in.) near Moab, to more than 30 in. in the La Sal Mountains (Sumsion, 1971; Blanchard, 1990; Steiger and Susong, 1997). The mean annual temperature near Moab (altitude 4,000 ft) is about 13 degrees Celsius $\left({ }^{\circ} \mathrm{C}\right)$, whereas the mean annual temperature in the La Sal Mountains (altitude 9,580 ft) is about $4{ }^{\circ} \mathrm{C}$ (data from SNOTEL (Snow Telemetry) station number 572 accessed November 5, 2018, at https://wcc.sc.egov.usda.gov/nwce/ site? sitenum $=572 \&$ state $=u t)$.

Principal streams within the study area are Mill, North Fork Mill, and Pack Creeks (fig. 1) and flow from southeast to northwest from the La Sal Mountains to the Colorado River. These three creeks join near Moab to become Mill Creek, which then discharges to the Colorado River in lower Spanish Valley (Sumsion, 1971). Other streams include Kane Springs Creek, which flows from east to west between the southern La Sal Mountains and Hatch Wash (outside of the study area); a stream from an unnamed canyon, locally known as Icebox Canyon, located 2.7 miles (mi) northwest of the Utah Highway 128/U.S. Highway 191 intersection, which flows from southeast to northwest to the Colorado River; and a stream from Grandstaff Canyon (formerly named Negro Bill Canyon), which flows from southeast to northwest from the Porcupine Rim to the Colorado River.

Groundwater within the study area is used for domestic supply, stock watering, and irrigation. Groundwater use data from the Utah Division of Water Rights website (https://www.waterrights.utah.gov/wateruse/WaterUseList.asp, accessed December 12, 2016) report 2015 groundwater withdrawal estimates of 810 acre-feet (acre-ft; for culinary use) from Moab City Water, and 970 acre-ft (60 acre-ft for irrigation, 910 acre- $\mathrm{ft}$ for culinary) from the Grand County Water Conservancy District (also known as the Grand Water and Sewer Service Agency, or GWSSA). These two agencies are the main public water suppliers in the Spanish Valley area. There is little data on the number of and withdrawals from privately owned wells in the study area.

\section{Purpose and Objectives}

The purpose of this study was to evaluate groundwater resources within the Spanish Valley area of southeastern Utah. The primary objectives were (1) to better understand sources of recharge to, groundwater-flow directions within, and discharge points for both the valley-fill and Glen Canyon Group aquifers (VFA and GCGA), and (2) to quantify groundwater budget components of the combined VFA and GCGA, including both recharge and discharge.

\section{Previous Investigations}

There have been several previous hydrogeologic studies conducted in the Spanish Valley area and vicinity. Sumsion (1971) examined the geology and water resources of MoabSpanish Valley and surrounding areas, providing an estimate of average annual water yield, quantifying the amount of groundwater available for beneficial use, and evaluating the effect of use on groundwater storage. Eychaner (1977) developed a digital model of the same area using data from Sumsion (1971) to investigate the effects of a proposed area of artificial recharge near what is now Ken's Lake, and increased well withdrawals for irrigation. Blanchard (1990) provided a reconnaissance of groundwater conditions in the bedrock aquifers of Grand County and parts of San Juan County, with emphasis on bedrock aquifers in the Mill Creek-Spanish Valley area. Steiger and Susong (1997) presented a map of recharge areas and groundwater-quality data for the Spanish Valley area. Kovacs (2000) developed a numerical groundwater-flow model to investigate the effects of increased well withdrawals in an unincorporated area of Moab-Spanish Valley at the request of the GWSSA. Gardner (2004) investigated the hydrogeology and groundwater conditions within the Scott M. Matheson Wetlands Preserve, located between Moab and the Colorado River, using a suite of environmental tracers to characterize the VFA at the downgradient part of Moab Valley. Lowe and others (2007) summarized the geology, groundwater conditions, and groundwater quality in Moab-Spanish Valley to determine the potential effects of projected increases in septic-tank systems on water quality in the VFA, and modified the numerical groundwater-flow model developed by Kovacs (2000). 


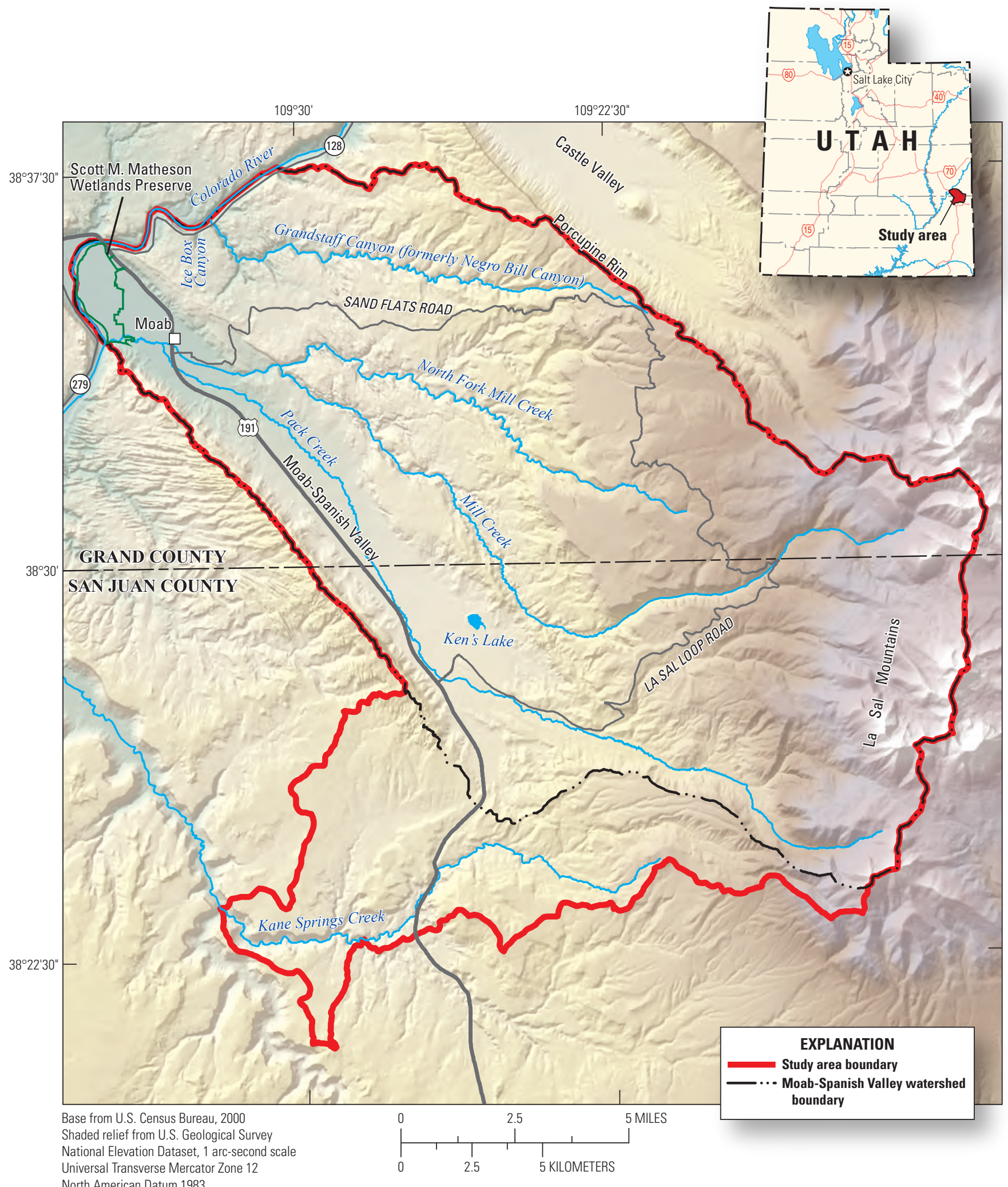

Figure 1. Location of the Spanish Valley study area, and the Moab-Spanish Valley watershed, Grand and San Juan Counties, Utah. 
Evaluation of Groundwater Resources in the Spanish Valley Watershed, Grand and San Juan Counties, Utah

\section{Approach}

The approach for investigation and meeting the purposes of this study included the following components: (1) providing a comprehensive hydrogeologic framework for the study area based on grouping geologic units into hydrogeologic units according to their capability to transmit or restrict the movement of groundwater; (2) constructing a preliminary net-infiltration map for outcrop areas of the Glen Canyon Group and Entrada Sandstone within the Moab-Spanish Valley watershed utilizing existing spatial data and information collected from newly drilled vadose-zone boreholes to evaluate recharge occurring in these areas; (3) collecting water samples from vadose-zone boreholes, wells, streams, and springs for geochemical analyses of major ions and selected trace elements, isotopic age-dating tracers, and noble gas recharge temperatures to improve understanding of the groundwater flow system; (4) making water-level measurements in wells to construct an updated water-level map used to evaluate likely directions of groundwater movement; (5) evaluating trends in groundwater levels; (6) making repeated discharge measurements from streams and springs during base-flow conditions to quantify the measurable amount of total discharge from the groundwater system; and (7) performing a geophysical characterization of shallow groundwater salinity and installing new monitoring wells at the terminal end of Moab-Spanish Valley, which were utilized to provide a revised estimate of subsurface groundwater discharge to the Colorado River. The combined analysis of these components allows for a comprehensive and updated conceptual model of groundwater flow and an updated groundwater budget for the Spanish Valley study area.

\section{Hydrogeologic Framework}

Based on studies by Rush and others (1982), Blanchard (1990), Freethey and Cordy (1991), Geldon (2003), and Lowe and others (2007), six aquifers and seven confining units were identified in the study area (table 1). Generally, the aquifers can be split into four types: (1) limestone aquifers of marine origin, (2) sandstone aquifers of eolian and marine origin, (3) sandstone and conglomerate aquifers of fluvial origin, and (4) valley-fill and other local aquifers in unconsolidated deposits. The permeability is a function of both the primary permeability from interstitial pore connectivity and secondary permeability created by karst features or faults and fractures. The vertical hydraulic connection between aquifers generally is restricted to strongly folded and fractured zones, which are concentrated along steeply dipping monoclines and in narrow regions encompassing igneous and salt intrusive masses (Jobin, 1962). The principal aquifers and confining units have varied in their aggregated classification between studies, and are not considered to be laterally or vertically homogeneous.

In the Spanish Valley area, there are two principal aquifers that currently supply the majority of irrigation and public supply water. The first is the VFA, which consists of unconsolidated Quaternary deposits (Sumsion, 1971; Lowe and others, 2007). The VFA is currently the principal groundwater source of irrigation water in the Spanish Valley area (Blanchard, 1990; Steiger and Susong, 1997; Lowe and others, 2007), although at one time it was the principal source of all groundwater used in Moab-Spanish Valley (Sumsion, 1971). The second is the GCGA, which consists of consolidated rocks of the Glen Canyon Group, namely the Lower Jurassic to Upper Triassic Wingate Sandstone, Kayenta Formation, and Navajo Sandstone (Blanchard, 1990; Freethey and Cordy, 1991; Lowe and others, 2007), and is the principal source of public drinking water (Blanchard, 1990; Steiger and Susong, 1997; Lowe and others, 2007). The water in the VFA is of slightly poorer quality than water in the GCGA, with higher total-dissolved solids concentrations (Steiger and Susong, 1997; Lowe and others, 2007).

Groundwater also has been developed in a group of several other Mesozoic-age sandstone aquifers including (from youngest to oldest): (1) the Dakota aquifer, which consists of the consolidated rocks of the Cretaceous Dakota Sandstone and the Burro Canyon Formation (Blanchard, 1990; Lowe and others, 2007); (2) the Morrison aquifer, which consists of consolidated rocks of the Upper Jurassic Salt Wash Member of the Morrison Formation (Lowe and others, 2007); and (3) the Entrada aquifer, which consists of consolidated rocks of the Middle Jurassic Moab Member of the Curtis Formation and the Middle Jurassic Slick Rock Member of the Entrada Sandstone (Blanchard, 1990; Lowe and others, 2007).

\section{Valley-Fill Aquifer (VFA)}

The VFA is composed of unconsolidated Quaternary-age deposits consisting of stream, alluvial fan, mass-movement (including glacial till), and eolian sand deposits (Steiger and Susong, 1997; Lowe and others, 2007). These deposits are composed of interbedded and lenticular deposits of sand, silt, and clay, and exist within the main lower-altitude basin of Moab-Spanish Valley (pl. 1). The average saturated thickness of the VFA in Moab-Spanish Valley is $70 \mathrm{ft}$, but in some places within the valley the saturated thickness can be more than $300 \mathrm{ft}$ (Sumsion, 1971; Lowe and others, 2007). 
Table 1. Principal aquifers and confining units within the Spanish Valley study area, Utah.

[Abbreviations: $\mathrm{ft}$, feet; $\mathrm{ft}^{2} / \mathrm{d}$, square feet per day; NR, not reported]

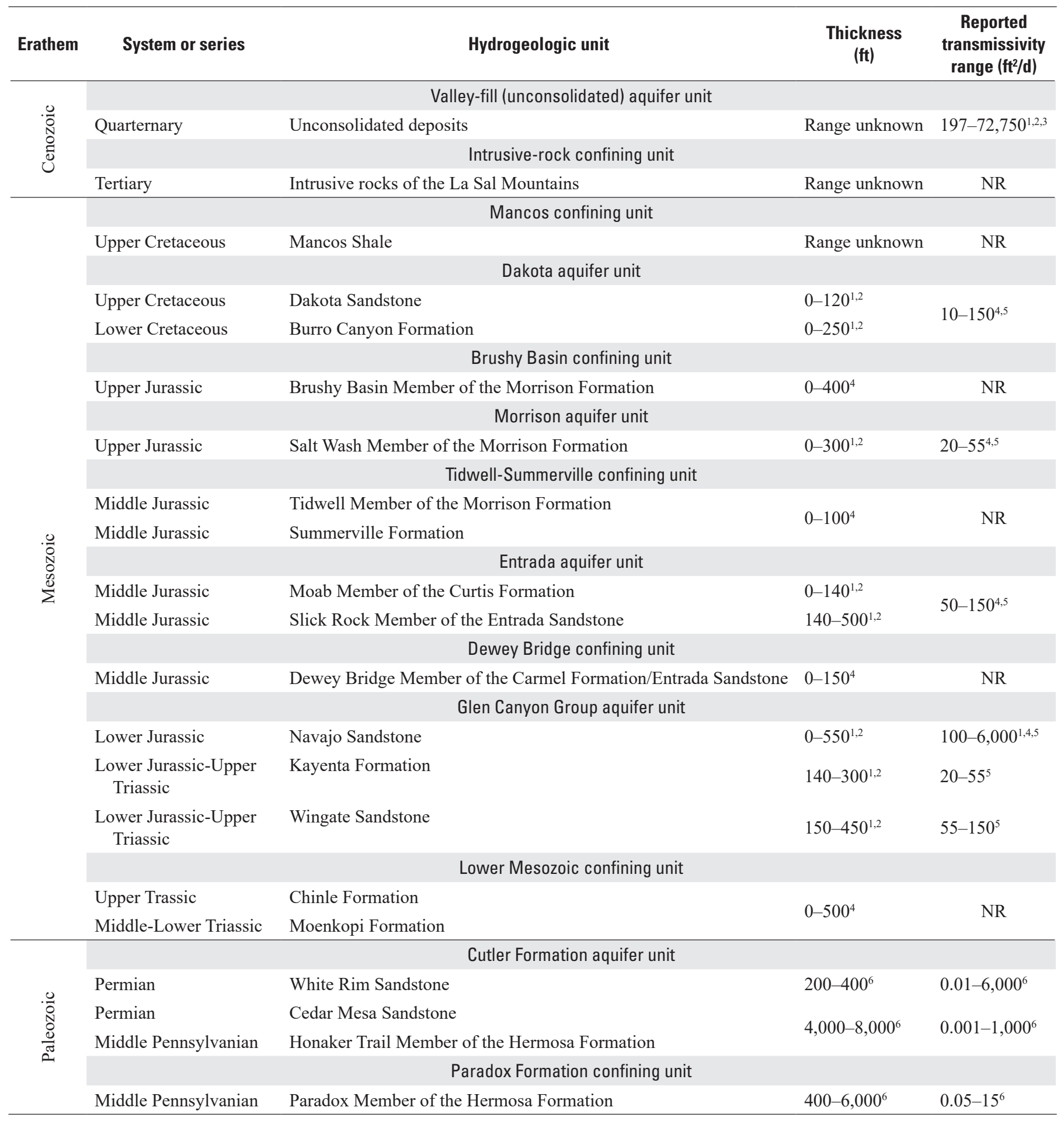

${ }^{1}$ Sumsion, 1971.

${ }^{2}$ Lowe and others, 2007.

${ }^{3}$ Current study.

${ }^{4}$ Freethey and Cordy, 1991.

${ }^{5}$ Jobin, 1962.

${ }^{6}$ Geldon, 2003. 
The VFA is classified as having a wide range of transmissivities (Lowe and others, 2007). Sumsion (1971) estimated transmissivities from 18 wells in the Moab-Spanish Valley ranging from 1,600 to 13,900 square feet per day $\left(\mathrm{ft}^{2} / \mathrm{d}\right)$, with an average of $6,000 \mathrm{ft}^{2} / \mathrm{d}$; based on aquifer data from pumping tests in basin-fill aquifers in other areas of Utah, Sumsion (1971) published a higher average value of about 10,000 ft²/d. Lowe and others (2007) estimated transmissivities from 32 wells (including those estimated by Sumsion, 1971) ranging from about 200 to $73,000 \mathrm{ft}^{2} / \mathrm{d}$, with an average of about $7,000 \mathrm{ft}^{2} / \mathrm{d}$. Estimated average transmissivities determined from aquifer tests at 12 new wells for the current study in and near the Matheson Wetlands Preserve ranged from about 90 to $5,400 \mathrm{ft}^{2} / \mathrm{d}$, with a median value of about $1,000 \mathrm{ft}^{2} / \mathrm{d}$ (see "Aquifer-Test Analysis" subsection under "Groundwater Budget" section in this report). Because there are no continuous layers of lowpermeability materials within the valley-fill deposits, the VFA is considered to be unconfined throughout most of MoabSpanish Valley (Sumsion, 1971), and is likely in hydraulic connection with the underlying GCGA along the eastern margin of the valley where the Lower Mesozoic confining unit is no longer continuous and outcropping (pl. 1).

\section{Glen Canyon Group Aquifer (GCGA)}

The GCGA consists of the Lower Jurassic- to Upper Triassic-age Wingate Sandstone, Kayenta Formation, and Navajo Sandstone (Rush and others, 1982; Blanchard, 1990; Freethey and Cordy, 1991; Lowe and others, 2007). The Wingate Sandstone is a well-sorted, very fine- to mediumgrained, calcareous, massively bedded, well-cemented, cross-bedded, eolian sandstone, and has a thickness of 150 to $450 \mathrm{ft}$ in the Spanish Valley area (Sumsion, 1971; Lowe and others, 2007). The Kayenta Formation is a very fine- to coarsegrained, locally conglomeratic, fluvial sandstone, siltstone and shale, and has a thickness of 140-300 ft (Sumsion, 1971; Lowe and others, 2007). The Navajo Sandstone is a wellrounded, well-sorted, fine- to medium-grained, cross-bedded eolian sandstone, and has a thickness of 0-550 ft (Sumsion, 1971; Lowe and others, 2007).

The Glen Canyon Group crops out along the northeastern and southwestern walls of Moab-Spanish Valley and to a large area east and northeast of Moab-Spanish Valley, and exists at depth below the unconsolidated deposits along the northeast margin of the valley floor (pl. 1; Doelling and others, 2002; Doelling, 2004). In many areas of the Colorado Plateau, the Kayenta Formation acts as a barrier to groundwater flow; in the Spanish Valley area, however, the unit is mainly composed of sandstone and provides hydraulic connection between the Navajo Sandstone and Wingate Formation
(Blanchard, 1990; Steiger and Susong, 1997). All three units are highly faulted and fractured, especially near the valley margins and along the flanks of the La Sal Mountains (pl. 1).

All three units in the Glen Canyon Group aquifer are classified as being moderately transmissive, which is further enhanced where fractures exist. Transmissivities of the aquifer range from less than 50 to $6,000 \mathrm{ft}^{2} / \mathrm{d}$ (Sumsion, 1971; Freethey and Cordy, 1991). Transmissivities for the Navajo Sandstone were estimated to range from 400 to $700 \mathrm{ft}^{2} / \mathrm{d}$ by Jobin (1962) and from 100 to 5,000 $\mathrm{ft}^{2} / \mathrm{d}$ by Freethey and Cordy (1991); Sumsion (1971) estimated transmissivities between 1,200 and 1,500 $\mathrm{ft}^{2} / \mathrm{d}$ in areas where the Navajo Sandstone is relatively unfractured, and up to $6,000 \mathrm{ft}^{2} / \mathrm{d}$ in areas where the Navajo Sandstone is highly fractured. These transmissivities for the Navajo Sandstone are similar to reported transmissivities from aquifer tests in other areas of the Navajo Sandstone (Heilweil and others, 2000). Transmissivities for the Kayenta Formation and the Wingate Sandstone were estimated by Jobin (1962) as ranging from 20 to $55 \mathrm{ft}^{2} / \mathrm{d}$, and 55 to $150 \mathrm{ft}^{2} / \mathrm{d}$, respectively. Near MoabSpanish Valley where the aquifer is connected to overlying formations and where the aquifer crops out, it is considered to be unconfined. Confined sections of the aquifer exist in the area surrounding Kane Springs and below the higher-altitude mesas to the east and southeast of Moab-Spanish Valley.

\section{Other Mesozoic-Age Sandstone Aquifers}

The Dakota, Morrison, and Entrada aquifers are important sources of groundwater to seeps and springs throughout the Spanish Valley area. These units occur locally along the flanks of the La Sal Mountains, along the topographic divide that is the southern boundary of MoabSpanish Valley, and in the Kane Springs area (pl. 1) (Doelling, 2004). These sandstone aquifers are often separated from one another by intervening confining units (table $1 ;$ pl. 1) such as (1) the Brushy Basin confining unit, which consists of the Upper Jurassic-age Brushy Basin Member of the Morrison Formation (Freethey and Cordy, 1991; Lowe and others, 2007), and separates the Dakota and Morrison aquifers; (2) the Tidwell-Summerville confining unit, which consists of the Middle Jurassic-age Summerville Formation and the Tidwell Member of the Morrison Formation (Rush and others, 1982; Lowe and others, 2007), and separates the Entrada and Morrison aquifers; and (3) the Dewey Bridge confining unit, which consists of the Middle Jurassic-age Dewey Bridge Member of the Carmel Formation/Entrada Sandstone (Rush and others, 1982; Lowe and others, 2007), and separates the Glen Canyon Group and Entrada aquifers. Discharge to the seeps and springs often occurs near the bases of these aquifers just above the intervening confining units. 


\section{Dakota Aquifer}

The Dakota aquifer consists of the Cretaceous-age Dakota Sandstone and Burro Canyon Formation. The Dakota Sandstone consists of sandstone and conglomerate, interbedded with siltstone, and has a thickness of 0 to $120 \mathrm{ft}$ in the Spanish Valley area (Sumsion, 1971; Lowe and others, 2007). The Burro Canyon Formation consists of sandstone and conglomerate interbedded with mudstone, and has a thickness of 0 to $250 \mathrm{ft}$ in the Spanish Valley area (Sumsion, 1971; Lowe and others, 2007). The Dakota aquifer is classified as being low to moderately transmissive, except where faulted or fractured where transmissivity is enhanced (Lowe and others, 2007). Jobin (1962) estimated transmissivities ranging between 55 and $150 \mathrm{ft}^{2} / \mathrm{d}$, and Freethey and Cordy (1991) estimated transmissivities ranging between 10 and $50 \mathrm{ft}^{2} / \mathrm{d}$. Recharge to the Dakota aquifer is likely from infiltration of precipitation that falls locally on areas where the aquifer crops out. Discharge from the aquifer occurs to seeps, springs, and flowing wells that typically discharge at less than 1 gallon per minute (gal/min) (Blanchard, 1990). Discharge also may occur to the underlying Morrison aquifer in areas where the Brushy Basin confining unit does not exist. Because the Dakota aquifer is not continuous throughout the Spanish Valley area, groundwater movement within the Dakota aquifer is likely towards localized discharge areas.

\section{Morrison Aquifer}

The Morrison aquifer consists of the Upper Jurassicage Salt Wash Member of the Morrison Formation. It is a well-sorted, fine- to medium-grained, fluvial cross-bedded sandstone, with less common conglomeratic sandstone interbedded with mudstone, and has a thickness of 0 to $300 \mathrm{ft}$ in the Spanish Valley area (Sumsion, 1971; Lowe and others, 2007). The Morrison aquifer is classified as having low transmissivity. Jobin (1962) estimated transmissivities ranging between 20 and $55 \mathrm{ft}^{2} / \mathrm{d}$, and Freethey and Cordy (1991) estimated transmissivities of less than $50 \mathrm{ft}^{2} / \mathrm{d}$. Similar to the Dakota aquifer, recharge is likely from infiltration of precipitation that falls locally on areas where the aquifer crops out, or in areas where the Brushy Basin confining unit does not exist between the overlying Dakota aquifer and the Morrison aquifer. Discharge from the aquifer occurs to seeps, springs, and flowing wells that typically discharge at less than $1 \mathrm{gal} / \mathrm{min}$ and are slightly saline (Blanchard, 1990; Lowe and others, 2007). Additionally, the Morrison Formation contains large quantities of uranium, and the groundwater can contain high concentrations of radionuclides (Blanchard, 1990).

Discharge may also occur to the underlying Entrada aquifer in areas where the Tidwell Member of the Morrison Formation and the Summerville Formation do not exist between the Morrison aquifer and the Entrada aquifer. Because the Morrison aquifer is not continuous throughout the Spanish Valley area, groundwater movement within the Morrison aquifer is likely towards localized discharge areas.

\section{Entrada Aquifer}

The Entrada aquifer consists of the Middle Jurassic-age Moab Member of the Curtis Formation and the Slick Rock Member of the Entrada Sandstone. The Moab Member of the Curtis Formation is a well-sorted, medium- to fine-grained, cross-bedded, eolian sandstone, and has a thickness of 0 to $140 \mathrm{ft}$ in the Spanish Valley area (Sumsion, 1971; Lowe and others, 2007). The Slick Rock Member of the Entrada Sandstone is a well-sorted, very fine- to medium-grained, cross-bedded sandstone of eolian or possibly shallow marine origin, and has a thickness of 140 to $500 \mathrm{ft}$ in the Spanish Valley area (Sumsion, 1971; Lowe and others, 2007). Both units of the Entrada aquifer are classified as being moderately transmissive. Jobin (1962) estimated transmissivities ranging between 55 and $150 \mathrm{ft}^{2} / \mathrm{d}$, and Freethey and Cordy (1991) estimated transmissivities ranging between 50 and $100 \mathrm{ft}^{2} / \mathrm{d}$ for the aquifer. Freethey and Cordy (1991) also estimated storage coefficients ranging between 0.0003 and 0.008 . Similar to the Dakota and Morrison aquifers, recharge is likely from infiltration of precipitation that falls locally on areas where the aquifer crops out, in areas where the Tidwell-Summerville confining unit does not exist between the overlying Morrison aquifer and the Entrada aquifer, or where the aquifer is mantled by unconsolidated deposits (Blanchard, 1990). Discharge from the aquifer occurs to wells, and to seeps and springs where the vertical hydraulic conductivity is decreased by contacts between crossbed sets or by the Dewey Bridge confining unit (Blanchard, 1990). Discharge also may occur to the underlying GCGA in areas where the Dewey Bridge confining unit does not exist between the Entrada aquifer and the GCGA, such as in the area to the east and northeast of Moab-Spanish Valley. Because the Entrada aquifer is not continuous throughout the Spanish Valley area, groundwater movement within the Entrada aquifer is likely towards localized discharge areas. 


\section{Sandstone Net-Infiltration Methods and Mapping}

Based on previous studies (Sumsion, 1971; Blanchard, 1990; Steiger and Susong, 1997), it was assumed that a substantial amount of recharge to the GCGA occurs along the 47,000-acre area where it crops out or is covered with thin soils within the study area. A preliminary net-infiltration (or groundwater recharge) map was constructed for the Glen Canyon Group and Entrada Sandstone areas within the Moab-Spanish Valley watershed part of the study area. The objectives of this map were (1) to identify areas of estimated low, medium, and high net infiltration, from which borehole locations were selected for vadose-zone environmental tracer collection to calculate point net-infiltration rates; and (2) to upscale these point measurements and estimate net infiltration for the entire outcrop area. For this report, net infiltration is defined as the infiltration of precipitation into the vadose zone beyond the maximum depth of the root zone. It is generally assumed that net infiltration is equal to groundwater recharge unless there are perched-water layers in the vadose zone; such perching would inhibit net infiltration, generally diverting it laterally towards incised drainages where it would discharge to springs and gaining stream reaches.

The net-infiltration map is a Geographic Information System (GIS)-based model that utilizes soils, topographic, precipitation, and outcrop data for predicting net infiltration to exposed and soil-covered areas of sandstone outcrops. It is based on a previous method used for predicting net infiltration to the Navajo Sandstone outcrop of Sand Hollow in southwestern Utah (Heilweil and McKinney, 2007). The GIS model determines the net-infiltration percentage of precipitation by using an empirical relation derived from leastsquares linear regression between three surficial parameters (soil coarseness, topographic slope, and downgradient distance from outcrop) that was calibrated to point-scale net-infiltration rates based on vadose-zone environmental tracer data. To estimate the spatial distribution of net-infiltration rates, a GIS grid of 9.3-square-meter $\left(\mathrm{m}^{2}\right)$ cells was constructed to represent the area of exposed and soil-covered sandstone outcrop areas. For soil-covered areas, separate GIS layers for soil coarseness, land-surface altitude, and bedrock outcrop data were developed to calculate net-infiltration ratios for each cell with the following equation from Heilweil and others (2007):

$$
\begin{aligned}
& R=0.178(A)+1.74 \times 10^{-4}(B)+1.07(C) \\
& -0.0273\left(A^{2}\right)-2.06 \times 10^{-6}\left(B^{2}\right)-3.14\left(C^{2}\right)
\end{aligned}
$$

where
$R \quad$ is the net-infiltration ratio, unitless;
$A \quad$ is the soil grain size, as the percent coarser than 0.15 millimeters;
$B$ is the downgradient distance from the sandstone outcrop, in meters; and
$C$ is the topographic slope, in percent.

These net-infiltration ratios were then multiplied by the average precipitation rate (in millimeters per year, or $\mathrm{mm} / \mathrm{yr}$ ) for each cell, resulting in a grid of estimated net-infiltration rates (in $\mathrm{mm} / \mathrm{yr}$ ).

Soil Survey Geographic Database (SSURGO) soil maps (U.S. Department of Agriculture Natural Resources Conservation Service, 2018) provided the basis for the GIS soil-coarseness layer. Soil-particle-size distributions provided with the SSURGO data did not coincide with the soil-coarseness parameter required for the net-infiltration model. Therefore, the SSURGO data were used for mapping soil types, but were supplemented by laboratory analysis of particle-size distributions to determine the soil coarseness for each of the 12 unique soil types in the outcrop area. Soil fractions ranged from 27 to 85 percent coarser than $0.15 \mathrm{~mm}$ for the different soil types (fig. 2). To evaluate spatial (horizontal and vertical) variability in soil coarseness within a soil unit, duplicate soil samples were collected at different locations and (or) depths for a subset of six of the sample types (table 2). In addition, one sample was split for analysis of replicates. The spatial variation and lab uncertainty were generally less than 10 percent.

The U.S. Geological Survey National Elevation Dataset 10-meter (m) Digital Elevation Model (DEM; National Center for Earth Resources Observation and Science, 1999) was used to calculate the topographic slope for each cell. The DEM data were hydrologically conditioned; artificial sinks and peaks were filled or leveled to remove inaccuracies resulting from errors in the creation of the DEM (McCoy and others, 2001). Slopes for each grid cell for the soil-covered parts of the Glen Canyon Group and Entrada Sandstone areas were calculated as vertical distance (or elevation change) divided by horizontal distance from the hydrologically conditioned DEM by using a three-cell by three-cell neighborhood surrounding each cell. The resulting GIS layer for the topographic-slope parameter has values ranging from about 0 to 30 percent (fig. 3). Based on field observations, areas with slopes of greater than 30 percent generally are not soil covered, and are assumed to be sandstone outcrops. 


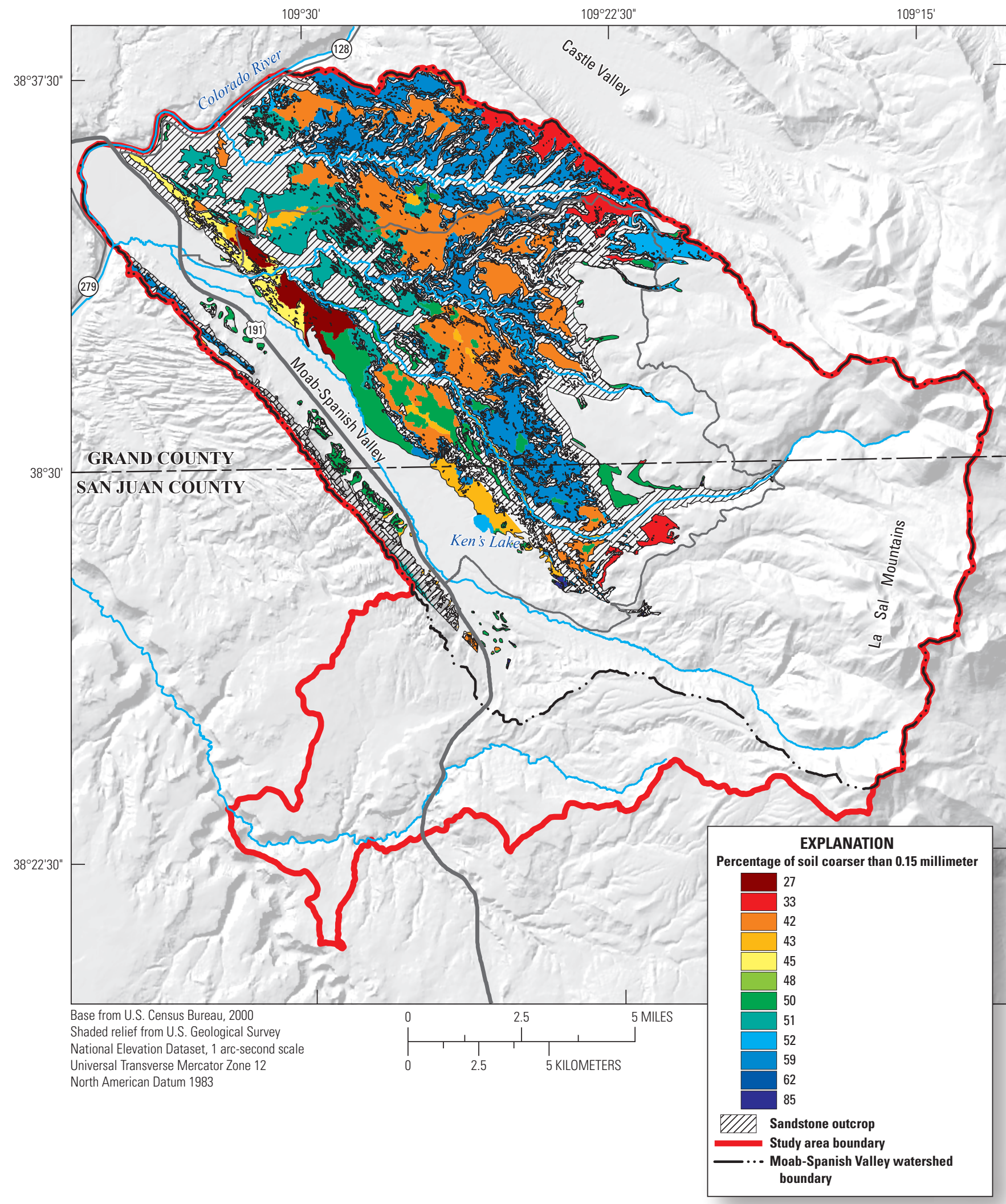

Figure 2. Soil coarseness for soils covering the Glen Canyon Group and Entrada Sandstone areas in the Moab-Spanish Valley watershed part of the Spanish Valley study area, Utah. 
Table 2. Coarseness of soil types covering the Glen Canyon Group and Entrada Sandstone areas in the Moab-Spanish Valley watershed part of the Spanish Valley study area, Utah.

[Latitude and longitude are referenced to the North American Datum of 1983. Abbreviations: ID, identification; mm, millimeters; 1vmf, Moenkopi-rock outcrop complex, 1- to 15-percent slopes; 1vm7, Mido loamy fine sand, dry, 2- to 8-percent slopes; 1vn3, rock outcrop-Ustic Torripsamments complex, 2to 15-percent slopes; 1vmy, Rizno, dry-rock outcrop complex, 3- to 15-percent slopes; 1vmz, rock outcrop; 1vn2, rock outcrop-Rizno, dry complex, 3- to 15-percent slopes; 1vnx, Ustic Torriorthents-Lithic Torriorthents, warmrock outcrop complex, 10- to 80-percent slopes; 1vmx, Rizno-rock outcrop complex, 3- to 15-percent slopes; 1vkn, Ustic Torriorthents-Ustollic Calciorthids complex, 10 - to 60-percent slopes; $1 \mathrm{vn} 0$, rock outcrop-Moenkopi complex, 3- to 15-percent slopes; 1vn1, rock outcrop-Rizno complex, 3- to 15-percent slopes; 1vkx, Bond-Rizno fine sandy loams, 3- to 15-percent slopes]

\begin{tabular}{clccc}
\hline $\begin{array}{c}\text { Sample } \\
\text { ID }\end{array}$ & Soil type ${ }^{1,2}$ & $\begin{array}{c}\text { Latitude } \\
\text { (decimal } \\
\text { degrees) }\end{array}$ & $\begin{array}{c}\text { Longitude } \\
\text { (decimal } \\
\text { degrees) }\end{array}$ & $\begin{array}{c}\text { Percent } \\
\text { coarser than } \\
\mathbf{0 . 1 5 ~ m m ~}\end{array}$ \\
\hline 150353 & 1vmf & 38.573152 & -109.526574 & 27.2 \\
150354 & 1vm7 & 38.575810 & -109.528202 & 43.2 \\
150355 & 1vn3_a & 38.575198 & -109.519509 & 53.4 \\
150356 & 1vn3_b & 38.582140 & -109.512415 & 48.0 \\
150357 & 1vmy & 38.574517 & -109.452918 & 42.5 \\
150358 & 1vmz & 38.584310 & -109.389253 & 48.3 \\
150359 & 1vn2_a & 38.439034 & -109.434231 & 59.1 \\
150360 & 1vn2_b & 38.439034 & -109.434231 & 64.1 \\
150361 & 1vn2_b & 38.439034 & -109.434231 & 59.0 \\
& (replicate) & & & \\
150362 & 1vnx & 38.437340 & -109.437712 & 61.5 \\
150363 & 1vmx_shallow & 38.426563 & -109.435186 & 30.5 \\
150364 & 1vmx_deep & 38.426563 & -109.435186 & 35.8 \\
150365 & 1vkn & 38.405260 & -109.447216 & 85.1 \\
150366 & 1vn0_shallow & 38.549155 & -109.505647 & 43.1 \\
150367 & 1vn0_deep & 38.549155 & -109.505647 & 47.0 \\
150368 & 1vn1_shallow & 38.573924 & -109.358758 & 40.4 \\
150369 & 1vn1_deep & 38.573924 & -109.358758 & 62.6 \\
150370 & 1vkx_shallow & 38.574950 & -109.355627 & 43.6 \\
150372 & 1vkx_deep & 38.574950 & -109.355627 & 52.9 \\
\hline
\end{tabular}

1" a" and "_b" indicate duplicate samples collected of the same type at different locations

${ }^{2}$ "_shallow" and "_deep" indicate soil collection at land surface or 1 meter depth, respectively.
Exposed sandstone areas were extracted from the soils coverage to make a separate GIS raster layer for calculating downgradient distances from outcrops. Surfacewater flow paths from all outcrop areas were determined with a downgradient influence algorithm (Tarboton, 1997) that calculates flow direction as the path from each GIS grid cell to its steepest downgradient neighboring cell. The downgradient influence flow paths (fig. 4) were calculated by applying the downgradient influence algorithm only to flow paths originating from outcrop areas. These flow paths show where runoff from exposed sandstone would flow during precipitation events in order to account for the higher netinfiltration rates that would occur at locations of soil-covered sandstone because of this ephemeral surface-water flow. The resulting GIS raster layer is a grid of downgradient distance values from outcrop areas to each soil-covered cell along a downgradient flow path. A maximum value of $200 \mathrm{~m}$ was used for this distance-from-outcrop parameter.

The three processed GIS raster data layers (soil coarseness, topographic slope, and downgradient distance) were applied as parameters in equation 1 by using the Map Algebra computational programming language (McCoy and others, 2001) to determine net-infiltration ratios for soil-covered areas of the Glen Canyon Group and Entrada Sandstone. These net-infiltration ratios were then multiplied by estimated annual precipitation data to obtain net-infiltration rates for each soil-covered grid cell. For areas of exposed sandstone, a constant net-infiltration ratio of 0.10 was used. This outcrop net-infiltration ratio was estimated from the tritium-based net-infiltration data from Sand Hollow and previous Navajo Sandstone infiltration studies near the Dirty Devil River (Danielson and Hood, 1984).

The net-infiltration ratios of both the soil-covered and exposed outcrop areas were then multiplied by annual precipitation to estimate net-infiltration rates. Estimated precipitation data are based on 30-year (1971-2000) average annual PRISM (Parameter-elevation Regressions on Independent Slopes Model) data (Spatial Climate Analysis Service, 2004). The PRISM average annual precipitation values for each grid cell ranged from 221 to $692 \mathrm{~mm} / \mathrm{yr}$ (fig. 5).

The resulting conceptual net-infiltration map (fig. 6) is presented in generalized terms of estimated low, medium, and high rates. This map was then used for determining the locations of boreholes for the collection of environmental tracers for calculating vadose-zone net-infiltration rates at these points. 


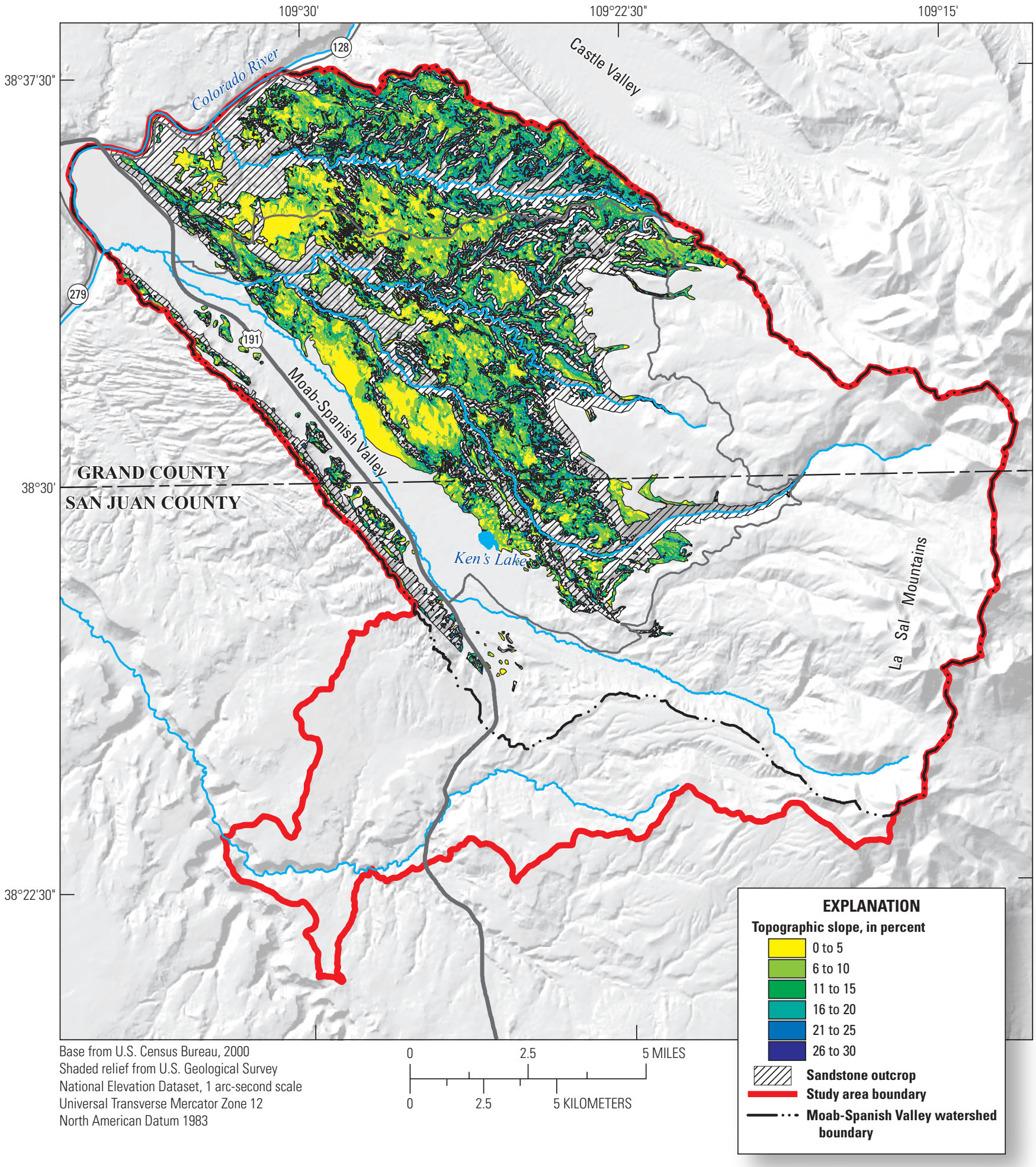

Figure 3. Topographic slope of soil-covered areas of the Glen Canyon Group and Entrada Sandstone in the Moab-Spanish Valley watershed part of the Spanish Valley study area, Utah. 


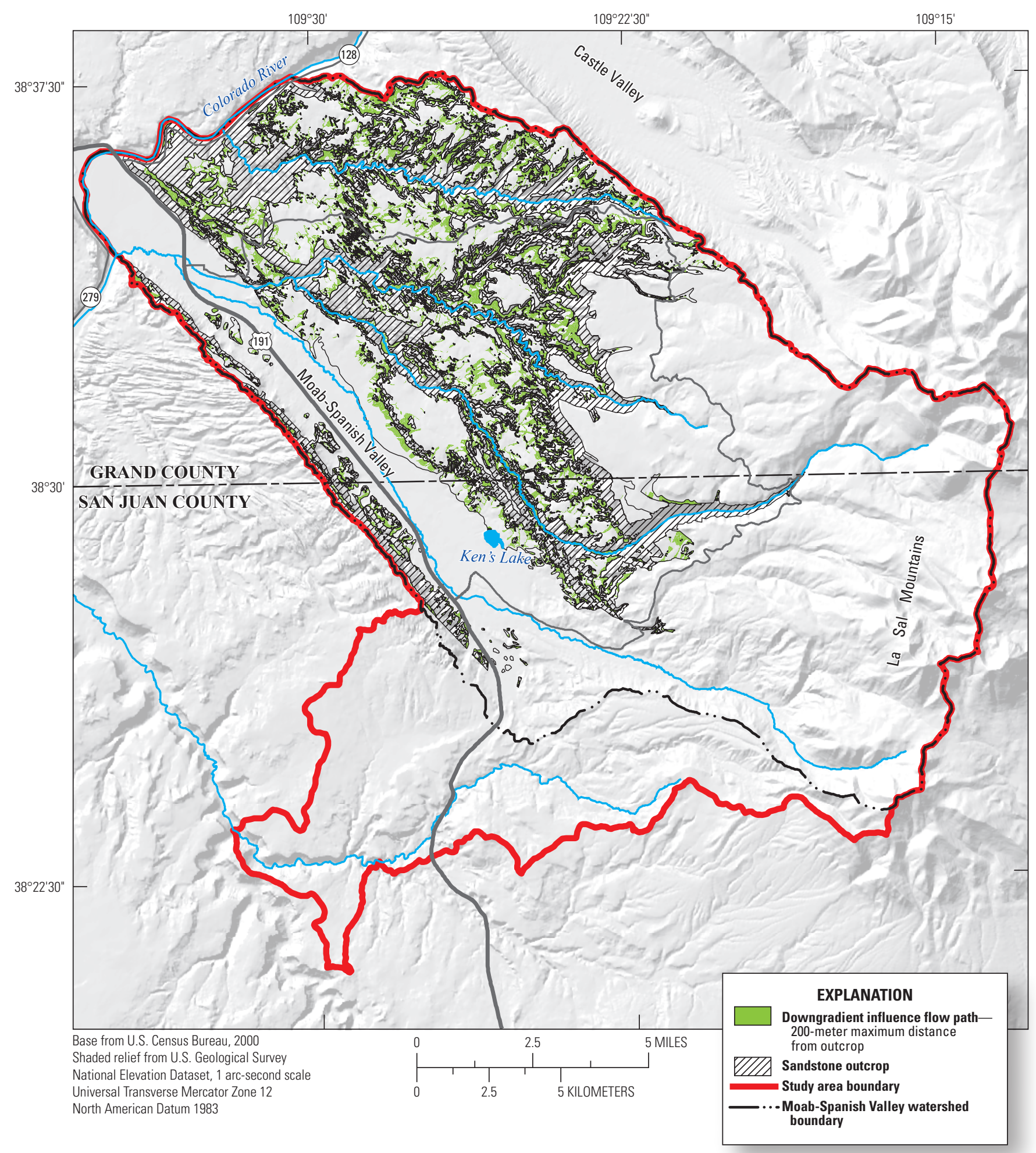

Figure 4. Downgradient influence flow paths on soils covering the Glen Canyon Group and Entrada Sandstone areas in the MoabSpanish Valley watershed part of the Spanish Valley study area, Utah. 


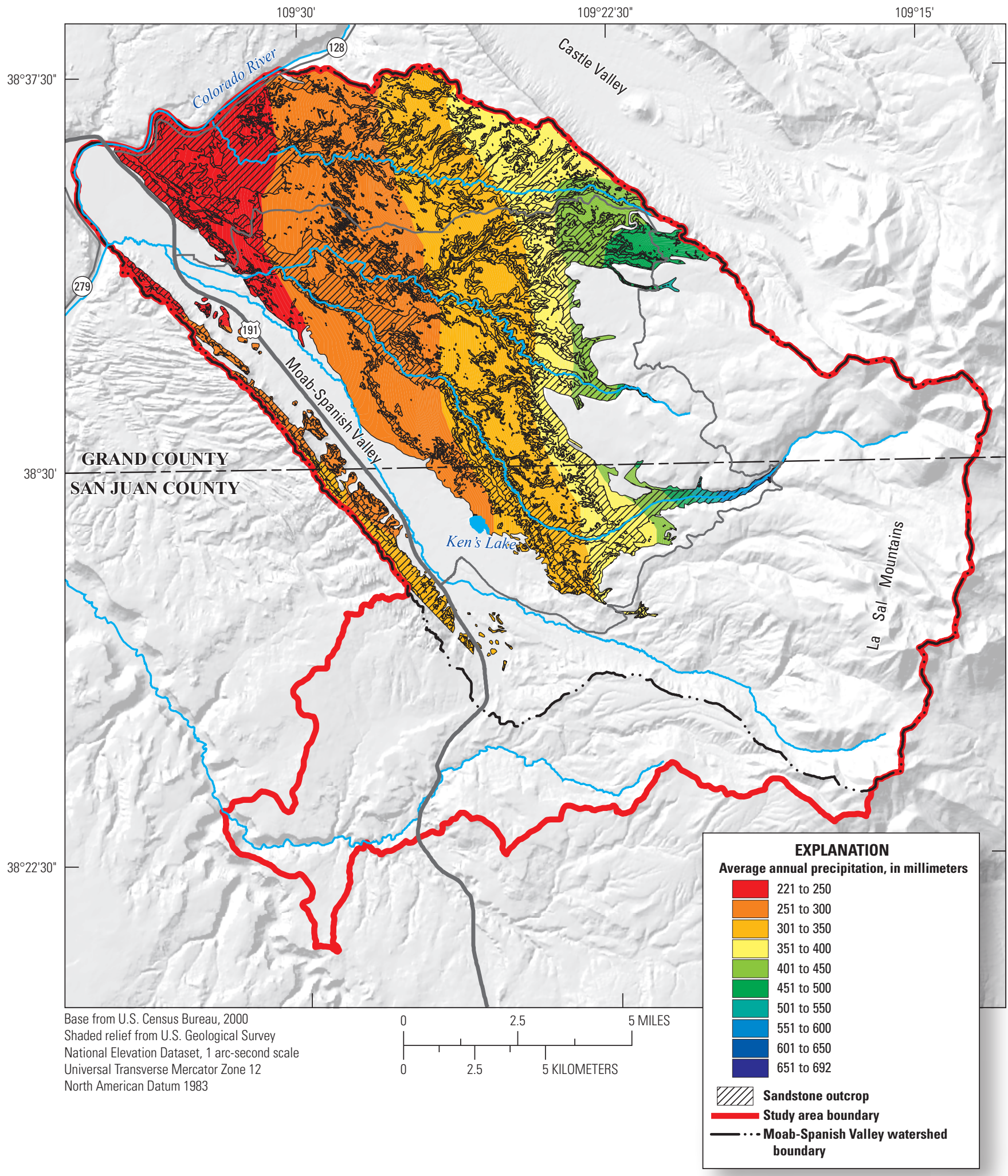

Figure 5. Distribution of average annual (1971-2000) precipitation on the Glen Canyon Group and Entrada Sandstone areas in the Moab-Spanish Valley watershed part of the Spanish Valley study area, Utah. 


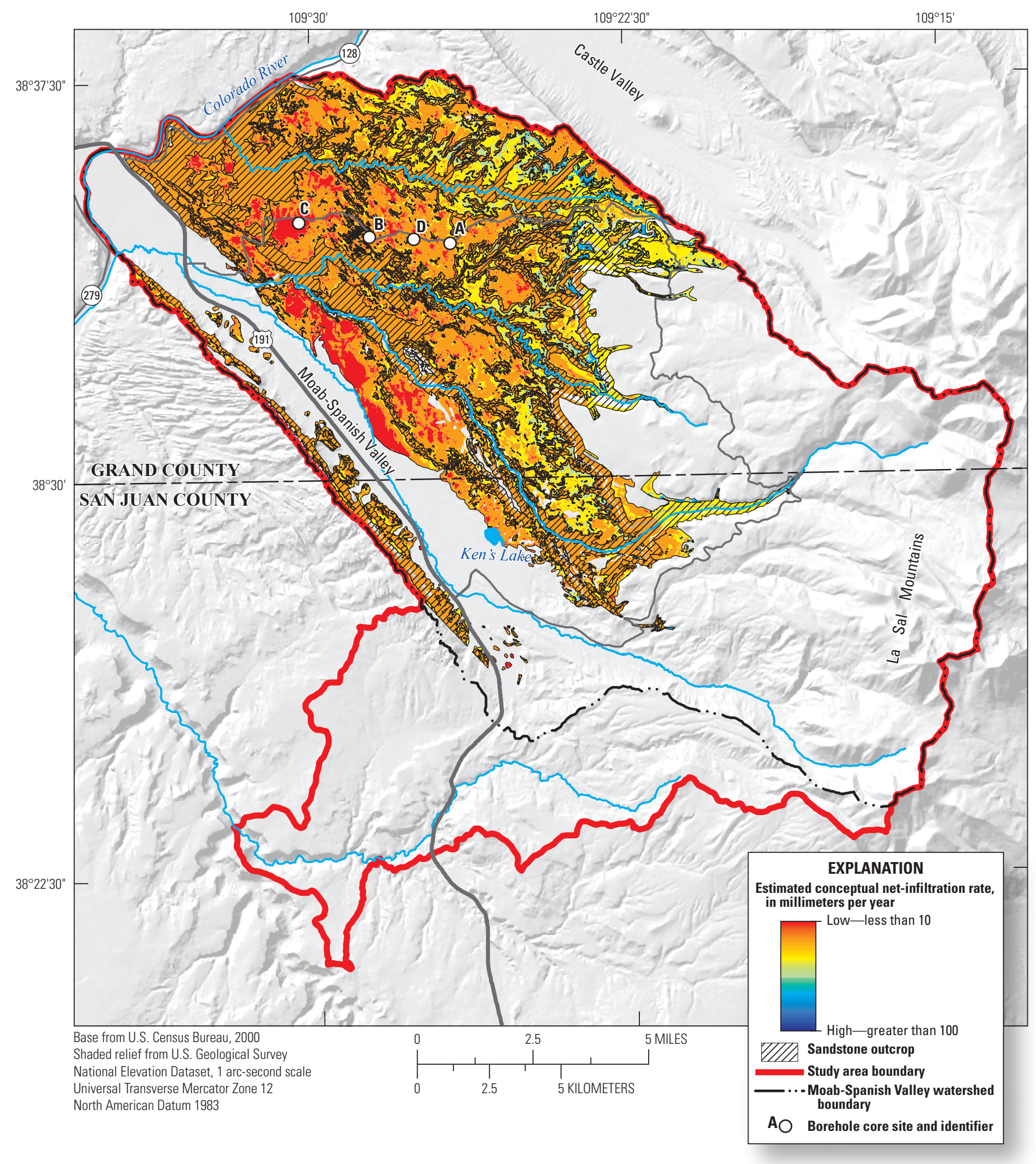

Figure 6. Distribution of estimated (pre-calibrated) conceptual net-infiltration rates on the Glen Canyon Group and Entrada Sandstone areas in the Moab-Spanish Valley watershed part of the study area, and locations of borehole core sites used to calculate vadose-zone net-infiltration rates on the sandstone areas, Spanish Valley study area, Utah. 


\section{Hydrochemical Characteristics}

\section{Environmental Tracer Geochemistry Background}

Environmental tracers were measured in water from both the vadose and saturated zones, and from streams within the study area. Environmental tracer data were used to investigate rates and sources of recharge and groundwater flow paths, to evaluate groundwater ages (traveltimes), and to support the development of a conceptual model describing flow through the groundwater system.

\section{Stable Isotopes of Oxygen and Hydrogen}

Stable isotope ratios of oxygen $\left({ }^{18} \mathrm{O}\right.$ and $\left.{ }^{16} \mathrm{O}\right)$ and hydrogen $\left({ }^{2} \mathrm{H}\right.$, or deuterium [D], and $\left.{ }^{1} \mathrm{H}\right)$ in water were analyzed to evaluate recharge sources and mixing between these sources in areas of convergent groundwater flow. Stable isotopes are analyzed by measuring the ratio of the heavier, less abundant isotopes $\left({ }^{18} \mathrm{O}\right.$ or $\left.\mathrm{D}\right)$ to the lighter, more abundant isotope $\left({ }^{16} \mathrm{O}\right.$ or $\left.{ }^{1} \mathrm{H}\right)$ and are reported as differences relative to a known standard. The isotope ratios are reported as delta $(\delta)$ values expressed as parts per thousand (permil, or \%o). The $\delta$ value for an isotope ratio, $R$, is determined by:

$$
\delta R=\left(\left[\frac{R_{\text {sample }}}{R_{\text {standard }}}\right]-1\right) \times 1,000
$$

where

$$
\begin{aligned}
& \delta R \quad \text { is the } \delta \text { value for a specific isotope in the } \\
& R_{\text {sample }} \quad \text { is the ratio of the less abundant isotope to the }
\end{aligned}
$$

The reference standard used in this report is Vienna Standard Mean Ocean Water (VSMOW; Craig, 1961b; Coplen, 1994).

The proportional variation in $\mathrm{D}$ and ${ }^{18} \mathrm{O}$ results in isotopic compositions of precipitation (and groundwater sourced from precipitation) that plot along a linear trend referred to as a meteoric water line when $\delta \mathrm{D}$ is plotted against $\delta^{18} \mathrm{O}$. The trend line for worldwide precipitation defines the Global Meteoric Water Line (GMWL; Dansgaard, 1964) and is described by the equation:

$$
\delta D=8\left(\delta^{18} O\right)+d
$$

where

$$
\begin{aligned}
& \delta D \quad \text { is the } \delta \text { value for hydrogen, in parts per } \\
& \text { thousand; } \\
& \delta^{18} O \quad \text { is the } \delta \text { value for oxygen, in parts per } \\
& \text { thousand; and } \\
& d \quad \text { is defined as the D excess (Dansgaard, 1964), } \\
& \text { in parts per thousand. The mean global } \\
& \text { value for } d \text { in freshwater is } 10 \text { (Craig, } \\
& \text { 1961a). }
\end{aligned}
$$

Depending on atmospheric conditions and sources of precipitation, isotopic data from specific areas may plot along a trend line that is above or below the GWML, generally referred to as a local meteoric water line, that better represents water in a drier climatic setting like that of the current study area (Welch and Preissler, 1986).

\section{Noble Gases}

Dissolved noble-gas samples $\left({ }^{20} \mathrm{Ne},{ }^{40} \mathrm{Ar},{ }^{84} \mathrm{Kr}\right.$, and $\left.{ }^{129} \mathrm{Xe}\right)$ were used to determine noble-gas recharge temperatures (NGTs, assumed to equal the temperature of groundwater recharge as it crosses the water table) to differentiate between mountain recharge and valley recharge. Noble gases dissolved in groundwater are primarily of atmospheric origin, and their concentrations are a function of their solubility (with the possible addition of excess air) at the temperature, pressure, and salinity conditions present as recharge crosses the water table. Because most noble-gas concentrations are geochemically inert, unlike physical temperatures and age tracers that change with time, noble-gas concentrations and, therefore, groundwater NGTs, should be preserved along the length of a groundwater flow path. A complete discussion of how these gases are used as groundwater tracers is included in Stute and Schlosser (2000). 
For this study, the noble-gas concentrations were interpreted using the closed-system equilibration (CE) model (Aeschbach-Hertig and others, 2000; Kipfer and others, 2002). In addition to recharge temperature, the CE model also calculates the dimensionless ratio of the total volume of trapped (moist) air at the pressure and temperature of the free atmosphere to the volume of water beneath the water table $\left(\mathrm{A}_{\mathrm{e}}\right)$ and a fractionation factor for partial dissolution of trapped air bubbles (F). Recharge altitude (the proxy for barometric pressure) is an unknown parameter, a typical situation in locations with a high topographic gradient. Because recharge temperature $\left(\mathrm{T}_{\mathrm{r}}\right)$ and recharge altitude $\left(\mathrm{H}_{\mathrm{r}}\right)$ are correlated, a range of NGTs (assumed to equal $\mathrm{T}_{\mathrm{r}}$ ) was estimated for each sample, as described by Manning and Solomon (2003) and Manning (2011). This method uses a minimum recharge altitude $\left(\mathrm{H}_{\min }\right)$, typically that of the sample site, to calculate a maximum noble-gas recharge temperature ( $\left.\mathrm{NGT}_{\max }\right)$. Conversely, the maximum possible recharge (water-table) altitude $\left(\mathrm{H}_{\max }\right)$ is used to calculate a minimum noble-gas recharge temperature $\left(\mathrm{NGT}_{\min }\right.$ ). For this study, $\mathrm{H}_{\max }$ was estimated to be $9,800 \mathrm{ft}$ for all samples based on evaluation of mapped exposures of high-altitude Glen Canyon Group rocks in the La Sal Mountains. The recharge parameters (NGT, $A_{e}$, and F) were evaluated using this range of recharge altitudes with a standard Newton inversion technique to minimize the error-weighted misfit $\left(\chi^{2}\right)$ between measured and modeled dissolved-gas concentrations (AeschbachHertig and others, 1999; Manning and Solomon, 2003). A $\chi^{2}$ probability threshold of 3.84 , based on four measured gases and three recharge parameters $(\mathrm{P}>0.05)$, was used to define good model fits for NGT, $\mathrm{A}_{\mathrm{e}}$, and F. Uncertainty in NGTs due to noble-gas measurement precision is generally 0.5 to $1.5^{\circ} \mathrm{C}$ (Manning and Solomon, 2003; Manning, 2009; Masbruch and others, 2012).

\section{Tritium and Helium Isotopes}

Tritium and helium isotopes were used in this study to examine the age of groundwater samples. Tritium $\left({ }^{3} \mathrm{H}\right)$ is a radioactive isotope of hydrogen with a half-life of 12.32 years that decays to tritiogenic helium-3 $\left({ }^{3} \mathrm{He}_{\text {trit }}\right)$. Tritium is present in water as part of the water molecule, whereas its decay product, ${ }^{3} \mathrm{He}_{\text {trit }}$, exists as a noble gas dissolved in water. During the 1950s and 1960s, large amounts of ${ }^{3} \mathrm{H}$ were released into the atmosphere and introduced into the hydrologic cycle by above-ground thermonuclear weapons testing. As a result, ${ }^{3} \mathrm{H}$ concentrations in precipitation in the northern hemisphere during 1963-64 peaked at three orders of magnitude above natural concentrations (Michel, 1989).

Concentrations of ${ }^{3} \mathrm{H}$ and ${ }^{3} \mathrm{He}_{\text {trit }}$ can be used to determine the apparent age of groundwater that is less than about 60 years old. These ages are referred to as "apparent" because they can differ from the true mean age of the sample if it contains a mixture of water of different ages. Mixtures of modern (post-mid-1950s recharge) and pre-modern (pre-mid1950 s recharge) water typically have apparent ${ }^{3} \mathrm{H} /{ }^{3} \mathrm{He}$ trit ages that represent the age of the young fraction of the sample because dilution with pre-modern water will leave the ratio of ${ }^{3} \mathrm{H}$ to ${ }^{3} \mathrm{He}_{\text {trit }}$ virtually unchanged. Further details of this groundwater dating method are presented in Solomon and Cook (2000).

Although ${ }^{3} \mathrm{H}$ in modern precipitation was not measured during this study, modern recharge is assumed to contain 6 to 9 tritium units (TU) based on reconstructing initial ${ }^{3} \mathrm{H}$ concentrations $\left({ }^{3} \mathrm{H}+{ }^{3} \mathrm{He}_{\text {trit }}\right)$ for mountain springs in the eastern Great Basin with estimated subsurface traveltimes of several years or less (Gardner and Heilweil, 2014). In a sample of premodern groundwater, ${ }^{3} \mathrm{H}$ will have decayed from background "prebomb" concentrations of about 6 to $9 \mathrm{TU}$ to less than $0.3 \mathrm{TU}$, which is approaching the analytical detection limit. Samples collected during this study having concentrations of $0.4 \mathrm{TU}$ or less (accounting for a typical analytical uncertainty of $0.1 \mathrm{TU}$ ) were interpreted to contain no modern water.

In addition to ${ }^{3} \mathrm{He}$ derived from ${ }^{3} \mathrm{H}$ decay, groundwater also accumulates dissolved helium as it is produced from the radioactive decay of naturally occurring uranium- and thorium-series elements in aquifer solids ("crustal He") and from the upward advection and (or) diffusion of primordial helium from the mantle ("mantle He"). Crustal- and mantlesourced He are collectively referred to as "terrigenic He" $\left(\mathrm{He}_{\text {terr }} ;\right.$ Solomon, 2000). Crustal- and mantle-sourced He are distinguishable by their relative abundance of ${ }^{3} \mathrm{He}$ and ${ }^{4} \mathrm{He}$ isotopes. These values are generally expressed as a ${ }^{3} \mathrm{He} /{ }^{4} \mathrm{He}$ ratio (R) relative to the atmospheric ${ }^{3} \mathrm{He} /{ }^{4} \mathrm{He}$ ratio $\left(R_{a}\right)$. Because crustal He has an $R / R_{a}$ value of approximately 0.02 and mantle $\mathrm{He}$ has an $\mathrm{R} / \mathrm{R}_{\mathrm{a}}$ value of approximately 10 to 30 , the $R / R_{a}$ of a water sample provides information on the relative amount of crustal and mantle sources of $\mathrm{He}_{\text {terr }}$. Modern groundwater has an $\mathrm{R} / \mathrm{R}_{\mathrm{a}}$ value approximately equal to 1 , indicating that it contains atmospheric solubility concentrations of He. In most aquifers, crustal He makes up the majority of the $\mathrm{He}_{\text {terr }}$. Where this is the case, the $\mathrm{R} / \mathrm{R}_{\mathrm{a}}$ value of groundwater will fall below 1 as it acquires $\mathrm{He}_{\text {terr }}$ from time spent in contact with aquifer materials. Because $\mathrm{He}_{\text {terr }}$ concentrations generally increase with increasing residence time, dissolved ${ }^{4} \mathrm{He}_{\text {terr }}$ concentrations have been used as a semiquantitative tool for dating groundwater with ages from 1,000 to more than 1,000,000 years (Mazor and Bosch, 1992; Solomon, 2000). No attempts were made to accurately date groundwater in this study using ${ }^{4} \mathrm{He}_{\text {terr }}$, because crustal $\mathrm{He}_{\text {terr }}$ production rates are highly variable and substantial additional data would have been required to constrain these rates within the study area. Solomon (2000) reported average crustal ${ }^{4} \mathrm{He}_{\text {terr }}$ production rates ranging from 0.28 to 2.4 microcubic centimeters per cubic meters per year at standard temperature and pressure $\left(\mu \mathrm{ccSTP} \mathrm{m}^{-3} \mathrm{yr}^{-1}\right)$. At these rates, groundwater should not acquire significant concentrations of ${ }^{4} \mathrm{He}_{\text {terr }}$ (more than about $2 \times 10^{-8}$ cubic centimeters of gas at standard temperature and pressure, per gram of water; $\mathrm{ccSTP} / \mathrm{g}$ ) until it has been in contact with aquifer materials for more than about 1,000 years. Even without precise knowledge of local ${ }^{4} \mathrm{He}_{\text {terr }}$ production rates, ${ }^{4} \mathrm{He}_{\text {terr }}$ concentrations in excess of atmospheric solubility are useful as qualitative measures of groundwater age. 


\section{Chlorofluorocarbons and Sulfur Hexaflouride}

Atmospheric chlorofluorocarbons (CFCs) and sulfur hexafluoride $\left(\mathrm{SF}_{6}\right.$ ) were used to evaluate the age of modern (post-mid-1950s recharge) groundwater or identify a component of modern water in a mixed signal. Atmospheric concentrations of CFCs (CFC-11, CFC-12, CFC-113) increased in a quasi-exponential fashion from the 1950s through the 1980s before it was recognized that CFCs contributed to the degradation of the ozone layer (Plummer and Busenberg, 2000). Subsequent reductions in production have led to decreasing atmospheric CFC concentrations over approximately the last 30 years. Atmospheric concentrations of $\mathrm{SF}_{6}$ have steadily increased since 1970 (Busenberg and Plummer, 2000) and have a long atmospheric lifetime (about 3,200 years; Land and Huff, 2009) making it a useful age tracer for young groundwater. Both CFC and $\mathrm{SF}_{6}$ concentrations are subject to potential anthropogenic and natural contamination and degradation. For example, $\mathrm{SF}_{6}$ is produced naturally in fluorite deposits and volcanic or hydrothermal terrains (Harnish and Eisenhauer, 1998; Busenberg and Plummer, 2000) while CFCs can be degraded in anaerobic sulfate reducing conditions (Cook and others, 2006). $\mathrm{CFC}$ and $\mathrm{SF}_{6}$ concentrations were corrected for excess air using the calculated value $\left(\mathrm{A}_{\mathrm{e}}\right)$ from noble gas modeling as described previously, and were not corrected for the potential unsaturated-zone lag time (Cook and Solomon, 1995).

\section{Carbon-14}

Carbon-14 $\left({ }^{14} \mathrm{C}\right)$ is a naturally occurring radioactive isotope that is useful for dating groundwater ranging from several hundred to more than 30,000 years. The method of ${ }^{14} \mathrm{C}$ dating is based on determining the initial ${ }^{14} \mathrm{C}$ concentration and the predictable rate of radioactive decay of ${ }^{14} \mathrm{C}$. Kalin (2000) and Han and Plummer (2016) provide comprehensive descriptions of the radiocarbon groundwater dating method.

In this study, the ${ }^{14} \mathrm{C}$ activity (effective concentration) of dissolved inorganic carbon (DIC) was used to estimate the age of a pre-modern component of sampled groundwater. Unadjusted ages were calculated from non-normalized ${ }^{14} \mathrm{C}$ activities of DIC using the Libby half-life (5,568 years), assuming an initial ${ }^{14} \mathrm{C}$ activity $\left(\mathrm{A}_{\mathrm{o}}\right)$ of 100 percent modern carbon $(\mathrm{pmC})$. The uncertainty in unadjusted radiocarbon ages is approximately several thousand years.

In systems with active carbonate geochemistry, a correction of ${ }^{14} \mathrm{C}$ activity accounts for processes other than radioactivity that affect the ${ }^{14} \mathrm{C}$ activity. DIC in precipitation is in equilibrium with atmospheric carbon dioxide $\left(\mathrm{CO}_{2}\right)$, but as precipitation infiltrates through the subsurface, the atmospheric ${ }^{14} \mathrm{C}$ activity is altered by isotopic and mass exchange with $\mathrm{CO}_{2}$, minerals, and organic carbon in the soilzone and saturated aquifer. As the non-atmospheric carbon sources have a ${ }^{14} \mathrm{C}$ activity less than $100 \mathrm{pmC}$, the exchange processes create an apparent dilution of the atmospheric signal. The purpose of the correction is to determine the ${ }^{14} \mathrm{C}$ activity of DIC at the time of recharge below the water table $\left(\mathrm{A}_{\mathrm{o}}\right)$ and is required to obtain accurate radiocarbon ages. This is accomplished by use of models that attempt to quantify the extent of geochemical evolution by tracking the stable carbon isotope ratio $\left(\delta^{13} \mathrm{C}\right)$ of the carbon sources and sample water.

Single-sample ${ }^{14} \mathrm{C}$ geochemical isotopic mass balance corrections used in this study (Han and Plummer, 2016) depend on differences in stable carbon isotope signatures of the carbon sources other than precipitation. Stable carbon isotope ratios $\left(\delta^{13} \mathrm{C}\right)$ in unsaturated zone $\mathrm{CO}_{2}$ and aquifer carbonate (calcite cement) were measured in this study to better constrain these geochemical corrections. Values of $-15.7 \%$ for $\delta^{13} \mathrm{C}$ and $100 \mathrm{pmC}$ for ${ }^{14} \mathrm{C}$ for $\mathrm{CO}_{2}$ were used in the unsaturated zone, and $-5.5 \%$ for $\delta^{13} \mathrm{C}$ and $0 \mathrm{pmC}$ for $\mathrm{CO}_{2}$ were used for aquifer carbonates. Following the graphical method of Han and others (2012, fig. 1, table 1) the appropriateness of an open (free exchange with atmosphere) or closed (below the water table limiting gas exchange with atmosphere) system equilibration assumption was evaluated for each sample. The graphical method also indicated possible geochemical evolution pathways resulting from geochemical processes alone. The so called "zero age" line defines regions of the diagnostic plots where no significant radioactive decay of ${ }^{14} \mathrm{C}$ is likely to have taken place. The revised Fontes and Garnier model (Han and others, 2012) was used to calculate the final corrected ${ }^{14} \mathrm{C}$ concentration.

\section{Vadose-Zone Environmental Tracers}

Chloride $(\mathrm{Cl})$ concentrations in atmospheric deposition and pore water (both within the vadose zone and beneath the water table) are often used for estimating rates of net infiltration (or recharge) using the $\mathrm{Cl}$ mass balance (CMB) method (Allison and Hughes, 1978; Allison, 1988; Allison and others, 1994). A simplified form of the CMB method from Wood and Sanford (1995) is:

$$
q_{C M B}=\frac{[C l]_{d e p}}{[C l]_{p w}} P
$$

where

$$
\begin{array}{cl}
q_{C M B} & \begin{array}{c}
\text { is the net-infiltration or recharge rate, in units } \\
\text { of length per time; } \\
\text { is the average } \mathrm{Cl} \text { concentration of atmospheric } \\
\text { deposition, in units of mass per cubic } \\
\text { length; }
\end{array} \\
{[\mathrm{Cl}]_{\text {dep }}} & \begin{aligned}
\text { is the average } \mathrm{Cl} \text { concentration of pore water, } \\
\text { in units of mass per cubic length; and }
\end{aligned} \\
\mathrm{Cl}]_{p w} & \begin{array}{c}
\text { is the precipitation rate, in units of length per } \\
\text { time. }
\end{array}
\end{array}
$$


Atmospheric $\mathrm{Cl}$ deposition includes $\mathrm{Cl}$ in both precipitation and dry dust accumulation. Including dry $\mathrm{Cl}$ deposition is important because it accounts for 50 to 90 percent of total $\mathrm{Cl}$ deposition in southeastern Utah (National Atmospheric Deposition Program, 2016). Whereas wet deposition is monitored weekly at Canyonlands National Park, Sand Hollow is the nearest location with published total $\mathrm{Cl}$ deposition. Measured total (wet plus dry) $\mathrm{Cl}$ deposition at Sand Hollow in southwestern Utah is 0.8 milligrams per liter $(\mathrm{mg} / \mathrm{L}$; Heilweil and others, 2006). The CMB method assumes that $\mathrm{Cl}$ deposition is constant with respect to time, there is no surfacewater $\mathrm{Cl}$ run-on or runoff at each borehole site, and all porewater $\mathrm{Cl}$ is of atmospheric origin.

The Navajo Sandstone is a clean, well-sorted, eolian sandstone containing no known evaporite or other salt deposits. However, because of the possibility of upward advective movement into the Navajo Sandstone of Cl-rich brines from underlying formations containing evaporite deposits, as documented at other study sites in Utah (Kimball, 1992; Naftz and others, 1997; Heilweil and others, 2000), Cl-to-bromide $(\mathrm{Br})$ ratios were determined to evaluate potential $\mathrm{Cl}$ contributions from geologic sources. Such geologic sources of $\mathrm{Cl}$ typically have $\mathrm{Cl}-\mathrm{Br}$ ratios exceeding 1,000 and the ratios increase with increasing groundwater $\mathrm{Cl}$ concentration (Davis and others, 1998).

Vadose-zone tritium concentrations also were used for evaluating net-infiltration rates using the tritium depth to peak (TDTP) method (Allison and Hughes, 1978; Allison, 1988; Allison and others, 1994). The peak ${ }^{3} \mathrm{H}$ in precipitation from above-ground nuclear testing in 1963 was originally three orders of magnitude above concentrations from natural ${ }^{3} \mathrm{H}$ production. The TDTP method calculates the long-term netinfiltration rate, $q_{T D T P}$, based on depth below land surface of the $1963{ }^{3} \mathrm{H}$ precipitation peak (for example, 52 years in 2015; Cook and others, 1994) using the equation:

$$
q_{T D T P}=\frac{z}{t} \theta_{v}
$$

where

$$
\begin{array}{cc}
q_{\text {TDTP }} & \begin{array}{c}
\text { is the net-infiltration rate, in units of length } \\
\text { per time; }
\end{array} \\
z & \begin{array}{c}
\text { is the depth below land surface, in units of } \\
\text { length, of the } 1963{ }^{3} \mathrm{H} \text { precipitation peak; }
\end{array} \\
t & \begin{array}{c}
\text { is the length of time between the } 1963{ }^{3} \mathrm{H} \\
\text { peak and the sample collection time; and }
\end{array} \\
\theta_{v} & \begin{array}{c}
\text { is the depth-weighted volumetric water } \\
\text { content of the vadose zone, unitless, } \\
\text { between land surface and the }{ }^{3} \mathrm{H} \text { peak. }
\end{array}
\end{array}
$$

The TDTP method assumes one-dimensional movement of water through the vadose zone and that volumetric water content throughout the profile does not change with time.

\section{Field and Laboratory Procedures}

Collection of vadose-zone core samples for environmental tracers was attempted at four borehole sites in areas of low and medium estimated net-infiltration rates along Sand Flats Road (fig. 6). No locations in areas with high estimated net-infiltration rates were accessible by road for the drill rig. Sites A (38.573889 N, $-109.443972 \mathrm{~W})$ and $\mathrm{D}(38.576222 \mathrm{~N},-109.459722 \mathrm{~W})$ were in areas with vegetated (sagebrush, juniper) sand dunes having no evidence of surface-water run-on (assumed to have only diffuse infiltration) at higher altitudes of 5,440 and 5,160 ft, respectively, with average annual precipitation rates of 310 and $290 \mathrm{~mm} / \mathrm{yr}$, respectively. Site B (38.578139 N, $-109.477833 \mathrm{~W}$ ) was located beneath an ephemeral wash (assumed to have focused infiltration) at an intermediate altitude of 4,950 ft, with an average annual precipitation rate of $270 \mathrm{~mm} / \mathrm{yr}$. Site C (38.5820 N, $-109.506222 \mathrm{~W})$ was in an area of vegetated (rabbitbrush, sagebrush) sand dunes having no evidence of surface-water run-on (assumed to have only diffuse infiltration) and a lower altitude of $4,710 \mathrm{ft}$, with an average annual precipitation of $250 \mathrm{~mm} / \mathrm{yr}$. Based on vadosezone studies of the Navajo Sandstone at Sand Hollow near St. George, Utah (Heilweil and others, 2006), it had been assumed that net-infiltration rates would be high beneath the ephemeral wash (site B) and low beneath the lower-altitude vegetated sand dunes. However, perched water above a thin ( 8 centimeters, or $\mathrm{cm}$ ) and very hard sandstone layer (likely indurated with silica cement) was encountered at a depth of about $45 \mathrm{ft}$ at both sites A and D. Loss of circulation beneath this depth in both holes prevented further drilling. These perched layers indicate that infiltration is likely impeded from moving downward towards the water table at these two sites.

Vadose-zone $\mathrm{Cl},{ }^{3} \mathrm{H}$, and stable isotope ratios of water $\left(\delta^{18} \mathrm{O}\right.$ and $\left.\delta \mathrm{D}\right)$ were analyzed from both pore waters and leachates of 16 core samples from the four borehole sites: seven depths at site B $(30,45,65,85,105,125,145 \mathrm{ft})$, seven depths at site $\mathrm{C}(30,50,70,90,105,130,150 \mathrm{ft})$, and one depth each at sites A and D (bottom of each borehole at $45 \mathrm{ft}$ ). Vadose-zone $\mathrm{Br}$ also was analyzed from a subset of 10 core samples. In addition, water from the perched lens below the bottom of borehole $\mathrm{D}(50 \mathrm{ft})$ also was analyzed.

To minimize contamination of the pore waters, cores were collected with a triple-tube continuous coring system with air as the drilling fluid. To minimize evaporative loss of water, the core samples were immediately heat-sealed in the field using a layered aluminum/plastic laminate. 
In the laboratory, each core sample was removed from its protective packaging, crushed, and split into three parts for analysis of (1) $\mathrm{Cl}$ and $\mathrm{Br},(2)^{3} \mathrm{H}$, and (3) $\delta^{18} \mathrm{O}$ and $\delta \mathrm{D}$. For $\mathrm{Cl}$ and $\mathrm{Br}$ analysis, samples were quickly weighed (to avoid evaporative loss), then oven-dried at $105^{\circ} \mathrm{C}$ for 24 hours to determine gravimetric water content. Based on replicate measurements, the uncertainty in gravimetric water content measurements is about 10 percent of the measured water content. Gravimetric water content was converted to volumetric water content assuming a bulk density of 1,980 kilograms per cubic meter $\left(\mathrm{kg} / \mathrm{m}^{3}\right)$ for the Navajo Sandstone (Heilweil and others, 2006). A sub-sample of about 200 milligrams $(\mathrm{mg})$ of dried sandstone was then added to an equal mass (about $200 \mathrm{mg}$ ) of de-ionized water and mixed vigorously by hand for 10 minutes to leach the salts. This leachate was left 24 hours for the suspended sediment to settle out and then filtered to 0.45 micrometers $(\mu \mathrm{m})$. A small subset of samples in which these sediments remained suspended also were centrifuged at 2,500 revolutions per minute (rpm) for 20 minutes to remove silts. $\mathrm{Cl}$ and $\mathrm{Br}$ concentrations in porewater leachates were analyzed at the U.S. Geological Survey National Water Quality Laboratory (NWQL) in Denver, Colorado, with reporting levels of 0.04 and $0.02 \mathrm{mg} / \mathrm{L}$, respectively. Pore-water $\mathrm{Cl}$ and $\mathrm{Br}$ concentrations were then calculated from the leachate concentration and core watercontent measurements.

For ${ }^{3} \mathrm{H}$ analysis, approximately 2 kilograms $(\mathrm{kg})$ of sample was quickly sealed in a stainless steel flask to avoid evaporative loss. Pore waters were then extracted by cryodistillation at the University of Utah's Dissolved Gas Service Center (DGSC). Pore-water tritium sample volumes were generally around 50 milliliters $(\mathrm{mL})$. Tritium concentrations in these vadose-zone pore waters were analyzed at the DGSC on a mass spectrometer after utilizing the helium in-growth method (Clarke and others, 1976), with a holding time of about 26 weeks.

For $\delta^{18} \mathrm{O}$ and $\delta \mathrm{D}$ analysis, the crushed sandstone was quickly sealed in 16-dram glass bottles with polyseal cone lids to avoid evaporative loss. Pore waters were then extracted by cryodistillation at the University of Utah's Stable Isotope Ratio Facility for Environmental Research (SIRFER).

Borehole cores were collected at sites B and C to depths of about $150 \mathrm{ft}$ (fig. 6). Unfortunately, cores were only collected to a depth of about $45 \mathrm{ft}$ at sites A and D, where perched water was encountered; this water prevented drilling beneath this depth because the air-based drilling and coring method only works in relatively low moisture content vadose zones (fig. 6). The perched zone was located immediately above an extremely well-cemented and hard layer, which likely had a low permeability and caused this perching.

\section{Chloride and Bromide}

Lab-reported $\mathrm{Cl}$ concentrations in leachate samples ranged from 0.35 to $5.6 \mathrm{mg} / \mathrm{L}$. Based on the measured gravimetric water content of each sample, these measured values were converted to pore-water $\mathrm{Cl}$ concentrations, ranging from 13 to $250 \mathrm{mg} / \mathrm{L}$ (table 3). The profiles of these results are shown in figure 7. Chloride concentrations beneath site B (ephemeral wash) were higher and more variable than site $\mathrm{C}$ (diffuse infiltration) and the CMB method could not be used because of the likelihood of run-on of $\mathrm{Cl}$ into the wash. $\mathrm{Cl}$ concentrations were relatively high at the maximum depth of sites A and D (about $50 \mathrm{ft}$ ) where perched water was encountered, indicating $\mathrm{Cl}$ concentrations were affected by evapotranspiration and low recharge rates at these sites.

Lab-reported $\mathrm{Br}$ concentrations in leachate samples were used to calculate $\mathrm{Cl}$ - $\mathrm{Br}$ ratios, which ranged from 25 to 274 (table 3), with an average of 120. This is consistent with the reported range of $\mathrm{Cl}-\mathrm{Br}$ ratios in atmospheric deposition of 100 to 200 for the southwestern United States (Davis and others, 1998). These results support the assumption that all $\mathrm{Cl}$ in the vadose zone of the Sand Flats area has an atmospheric (rather than geologic) source.

The net-infiltration rate for site $\mathrm{C}$ was calculated with the $\mathrm{CMB}$ method (eq. 4). An average vadose-zone $\mathrm{Cl}$ concentration of about $19 \mathrm{mg} / \mathrm{L}$ was calculated in pore water from seven samples from 30 to $150 \mathrm{ft}$ deep (table 3 ). The estimated concentration of atmospheric $\mathrm{Cl}$ deposition in Spanish Valley was estimated to be about $0.8 \mathrm{mg} / \mathrm{L}$, based on previous studies in southwestern Utah (Heilweil and others, 2006). Using this value in equation 4 , the calculated CMB net-infiltration rate was about $14 \mathrm{~mm} / \mathrm{yr}$. Because of the perched water encountered at depths of about $50 \mathrm{ft}, \mathrm{CMB}$ netinfiltration rates were not meaningful for sites $\mathrm{A}$ and $\mathrm{D}$ and, therefore, were not calculated. Because of the likely run-on of $\mathrm{Cl}$ during precipitation events at site $\mathrm{B}$ (ephemeral wash), a CMB net-infiltration rate also was not calculated.

\section{Tritium and Moisture Content}

Vadose-zone pore waters from boreholes within the Sand Flats area had ${ }^{3} \mathrm{H}$ concentrations ranging from about 0.1 to $7.5 \mathrm{TU}$ (table 3 ). Uncertainty in the pore-water tritium analysis ranged from 0.04 to $0.45 \mathrm{TU}$. The tritium profile at site $\mathrm{C}$ (diffuse infiltration) had a peak of about 7.5 TU at a depth of $90 \mathrm{ft}$ (fig. 7). In contrast, the tritium profile at site B (ephemeral wash) shows concentrations of less than $1 \mathrm{TU}$ at all depths (fig. 7). 
Table 3. Summary of environmental tracers collected from vadose-zone borehole core samples from the Navajo Sandstone outcrop part of the Spanish Valley study area, Utah.

[Abbreviations: ID, identification; ft, feet; $\mathrm{Cl}$, chloride; $\mathrm{mg} / \mathrm{L}$, milligrams per liter; $\mathrm{Br}$, bromide; ${ }^{3} \mathrm{H}$, tritium; $\mathrm{TU}$, tritium units; $\delta \mathrm{D}_{\mathrm{vsmow}}$, ratio of ratio of deuterium or hydrogen-2 to hydrogen-1 in sample to ratio of deuterium or hydrogen-2 to hydrogen-1 in reference, which is Vienna Standard Mean Ocean Water; permil, parts per thousand; $\delta^{18} \mathrm{O}_{\mathrm{vsmow}}$, ratio of ratio of oxygen-18 to oxygen-16 in sample to ratio of oxygen-18 to oxygen-16 in reference, which is Vienna Standard Mean Ocean Water; - , no data; NA, not applicable]

\begin{tabular}{lcccccccc}
\hline \multicolumn{1}{c}{ Sample ID } & $\begin{array}{c}\text { Depth } \\
\text { (ft) }\end{array}$ & $\begin{array}{c}\text { Volumetric } \\
\text { water content }\end{array}$ & $\begin{array}{c}\text { Pore water } \mathbf{C l} \\
\text { (mg/L) }\end{array}$ & $\mathbf{C l / B r}$ & $\begin{array}{c}{ }^{3} \mathbf{H} \\
\text { (TU) }\end{array}$ & $\begin{array}{c}{ }^{3} \mathbf{H} \text { error } \\
\text { (TU) }\end{array}$ & $\begin{array}{c}\mathbf{\delta}_{\text {vsmow }} \\
\text { (permil) }\end{array}$ & $\begin{array}{c}\boldsymbol{\delta}^{18} \mathbf{O}_{\text {vsmow }} \\
\text { (permil) }\end{array}$ \\
\hline A9 & $45-50$ & 0.085 & 83.37 & 48 & 4.60 & 0.21 & -97.0 & -11.8 \\
B6 & $30-35$ & 0.079 & 113.37 & 82 & 0.87 & 0.09 & -95.2 & -12.5 \\
B9 & $45-50$ & 0.043 & 250.42 & 180 & 0.38 & 0.13 & -98.9 & -12.9 \\
B13 & $65-70$ & 0.038 & 61.06 & 95 & 0.13 & 0.10 & -96.4 & -12.7 \\
B17 & $85-90$ & 0.036 & 41.52 & - & 0.24 & 0.08 & -93.0 & -12.2 \\
B21 & $105-110$ & 0.063 & 37.33 & 25 & 0.17 & 0.08 & -93.9 & -12.0 \\
B25 & $125-130$ & 0.053 & 180.67 & 45 & 0.50 & 0.06 & -95.5 & -11.9 \\
B29 & $145-150$ & 0.069 & 28.99 & 182 & 0.21 & 0.05 & -98.1 & -11.7 \\
C6 & $30-35$ & 0.061 & 28.74 & 71 & 3.67 & 0.21 & -94.8 & -10.1 \\
C10 & $50-55$ & 0.078 & 18.26 & - & 5.44 & 0.33 & -98.1 & -11.4 \\
C14 & $70-75$ & 0.065 & 16.13 & - & 6.31 & 0.34 & -92.2 & -9.8 \\
C18 & $90-95$ & 0.064 & 14.85 & - & 7.47 & 0.45 & -99.6 & -11.4 \\
C21 & $105-110$ & 0.091 & 22.79 & 274 & 0.36 & 0.08 & -97.2 & -11.2 \\
C21 (replicate) & $105-110$ & 0.097 & 10.35 & - & - & - & -96.9 & -11.0 \\
C26 & $130-135$ & 0.046 & 17.18 & - & 0.33 & 0.07 & -92.5 & -9.7 \\
C30 & $150-155$ & 0.051 & 13.28 & - & 0.30 & 0.11 & -95.5 & -10.8 \\
D9_perched & $40-45$ & NA & 173.97 & 154 & 3.47 & 0.14 & -92.7 & -11.6 \\
D10 & $45-50$ & 0.098 & 79.84 & 166 & 0.43 & 0.04 & -93.2 & -10.3 \\
\hline
\end{tabular}

Measured vadose-zone gravimetric water content of the 16 vadose-zone core samples ranged from 1.8 to 5.1 percent. Multiplying by a bulk density of 1.98 grams per cubic centimeter $\left(\mathrm{g} / \mathrm{cm}^{3}\right)$ based on previously published data (90 core measurements of the Navajo Sandstone in southwestern Utah; Heilweil and others, 2006), calculated volumetric water contents ranged from about 4 to 10 percent. The average vadose-zone volumetric water content was about 6 percent for seven depths at the ephemeral wash site (B) and about 7 percent for seven depths at the diffuse infiltration site (C). This was in contrast to a previous Navajo Sandstone study (Heilweil and others, 2006) that showed higher moisture content in the vadose zone beneath ephemeral washes and areas receiving runoff compared to diffuse infiltration sites not receiving runoff. At the Sand Flats sites, the volumetric water content at the $50-\mathrm{ft}$ depth was between 8 and 10 percent for the three diffuse infiltration sites (A, C, D), compared to 4 percent beneath the ephemeral wash (site B).

The TDTP method (eq. 5) was used to calculate the net-infiltration (recharge) rate for site $\mathrm{C}$. With the depth of the peak at $90 \mathrm{ft}$, a traveltime of 52 years between the 1963 atmospheric tritium peak and the 2015 sampling year, and an average volumetric moisture content of 6.8 percent from land surface to $90 \mathrm{ft}$, the net-infiltration rate was $35 \mathrm{~mm} / \mathrm{yr}$. A netinfiltration rate could not be calculated for site B since there is no identifiable peak tritium concentration in the profile. The low ${ }^{3} \mathrm{H}$ concentrations and water content throughout the profile at site $\mathrm{B}$, however, indicated very low net infiltration, which was unexpected because ephemeral washes typically have higher infiltration rates than elsewhere in desert landscapes due to focusing of flow (Stonestrom and others, 2003).

Although no perched water was observed during drilling at site $\mathrm{B}$, it is possible that there is a low permeability layer limiting downward infiltration, as indicated by the low vadosezone tritium concentrations. In contrast to previous sandstone infiltration studies (Heilweil and Solomon, 2004; Heilweil and others, 2006; Heilweil and others, 2007), this indicates higher recharge rates at the diffuse site and little focused recharge occurring beneath the wash. 

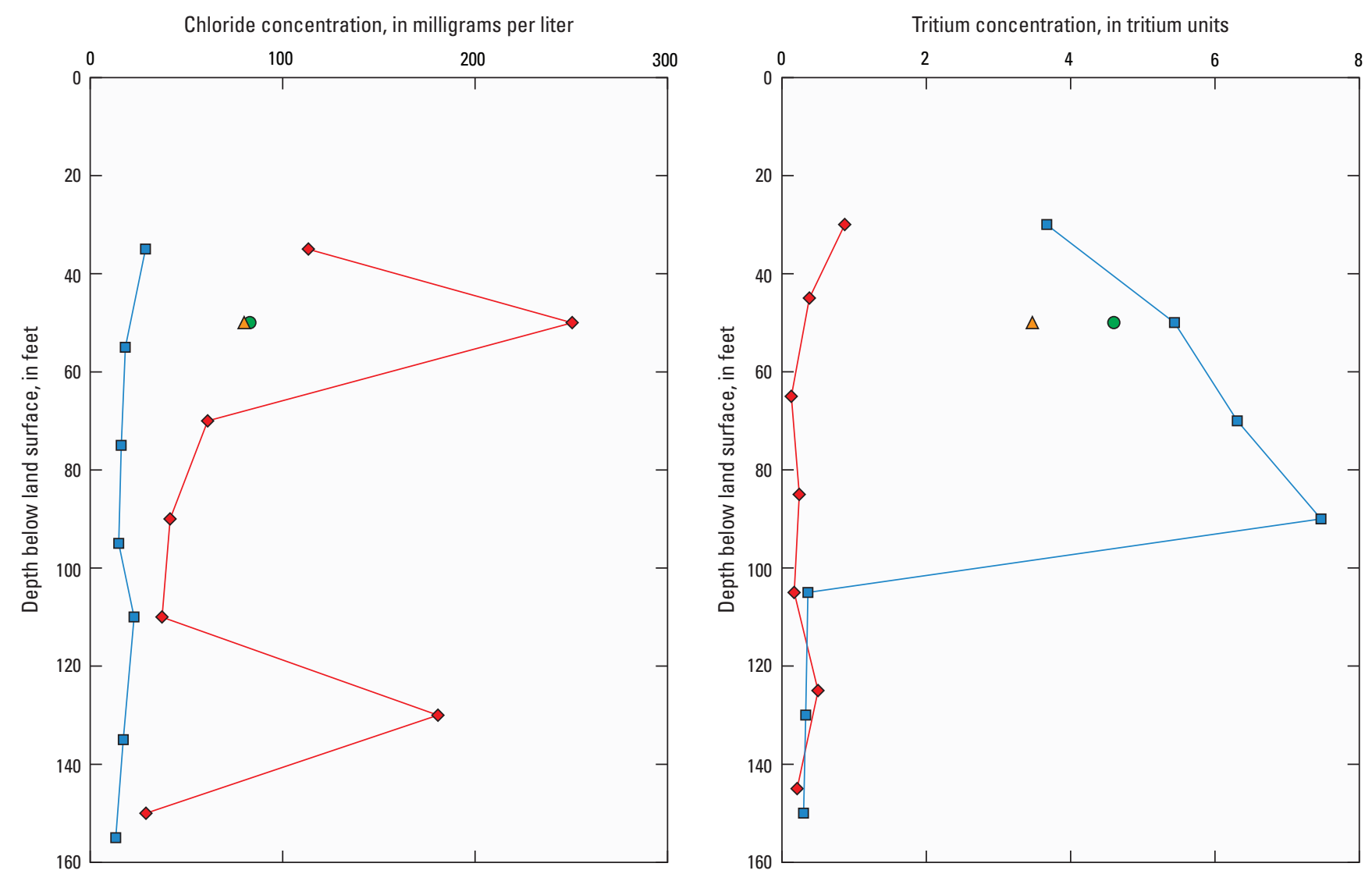

\section{EXPLANATION}

Site A Core-Diffuse infiltration-Higher altitude Site B Core-Ephemeral wash

Site C Core-Diffuse infiltration-Lower altitude

Site D Core-Diffuse infiltration-Medium altitude

Figure 7. Vadose-zone concentration profiles for chloride (left) and tritium (right) in leachate samples from cores collected at four borehole sites along Sand Flats Road, Spanish Valley study area, Utah.

\section{Stable Isotopes}

Vadose-zone $\delta \mathrm{D}$ and $\delta^{18} \mathrm{O}$ ranged from about -92 to $-99 \%$ and about -10 to $-13 \%$, respectively (table 3 ). These data are discussed below in the context of the surface-water and groundwater stable isotopic data in the "Stable Isotopes" subsection of the "Groundwater and Surface-Water Samples" section of this report.

\section{Groundwater and Surface-Water Samples}

Water samples were collected from 51 sites in the Spanish Valley study area that included domestic, municipal, and irrigation wells, 9 perennial springs, and 4 stream locations. These samples also were analyzed for a suite of environmental tracers that included the stable isotope ratios of $\delta^{18} \mathrm{O}, \delta \mathrm{D}$, and carbon $\left(\delta^{13} \mathrm{C}\right.$, ratio of carbon-13 to carbon- 12$)$, dissolved noble gases $\left({ }^{3} \mathrm{He} ;{ }^{4} \mathrm{He}\right.$; neon, $\mathrm{Ne}$; argon, Ar; krypton, $\mathrm{Kr}$; xenon, $\mathrm{Xe}$ ), dissolved industrial gases ( $\mathrm{SF}_{6}$, and $\mathrm{CFCs}$ ), and radioactive isotopes of carbon $\left({ }^{14} \mathrm{C}\right)$ and hydrogen $\left({ }^{3} \mathrm{H}\right)$. Water samples from these sites were analyzed for major ions and nutrients to characterize general chemistry and waterquality patterns, and to evaluate groundwater source areas and flow paths within the study area. ${ }^{3} \mathrm{H} /{ }^{3} \mathrm{He}, \mathrm{SF}_{6}, \mathrm{CFCs}$, and ${ }^{14} \mathrm{C}$ were used for groundwater dating. 
Results of the analyses of dissolved concentrations of major ions, nutrients, stable and radio isotopes, dissolvedgases and related noble-gas temperature data are presented in the following sections. To clarify their description, many of the samples are grouped into four categories based primarily on their geographic location or, in the case of groundwater, the aquifer that they are associated with. These categories are as follows: (1) Glen Canyon Group aquifer waters (GCGA) are groundwater samples collected from wells and springs within Glen Canyon Group rocks in the vicinity of the northeast margin of Moab-Spanish Valley; (2) Pack Creek drainage waters (PCD) are surface and groundwater samples collected either from Pack Creek or from wells and springs in the Pack Creek watershed above Moab-Spanish Valley (generally above $5,700 \mathrm{ft}$ in altitude); (3) Valley-fill aquifer waters (VFA) are groundwater samples issuing from wells and springs screened in alluvial material or underlying bedrock within the middle of Moab-Spanish Valley; and (4) Lower valley-fill aquifer waters (LVFA) are groundwater samples collected at the lowest altitudes of Moab-Spanish Valley, located between $500 \mathrm{~W}$ Street (in Moab) and the Colorado River near irrigated lands and the Matheson Wetlands Preserve (wetland). It is important to note that Pack Creek stream samples during base-flow periods were assumed to represent groundwater discharge to Pack Creek higher in the basin.

\section{Sample Collection and Analysis}

Water samples were collected from wells using either a portable or dedicated submersible pump. Samples were collected from springs under natural, free-flowing conditions. Wells that required pumping were purged of a minimum of three casing volumes of water prior to sample collection and water was collected from an outlet as close to the wellhead as possible.

Field parameters measured during water-sample collection included specific conductance, $\mathrm{pH}$, temperature, dissolved oxygen, and total dissolved-gas pressure. These parameters were measured using a calibrated multi-meter probe following USGS protocols (Wilde and Radtke, 1998). Samples for dissolved major ions and nutrients were filtered with a 0.45 -micron filter. The cation subsample was preserved with nitric acid. Dissolved major-ion and nutrient analyses were performed by the USGS NWQL in Denver, Colorado.

Unfiltered samples for stable isotopes of oxygen and hydrogen were collected in 60-mL glass containers, sealed with polyseal caps leaving no air space, and analyzed by SIRFER at the University of Utah. The 2-standard deviation $(\sigma)$ uncertainty of oxygen and hydrogen isotopic measurements is 0.2 and $2 \%$, respectively. Unfiltered samples for ${ }^{3} \mathrm{H}$ were collected in 500-mL or 1-liter (L) polyethylene bottles, sealed with no air space in the container, and analyzed by the University of Utah DGSC in Salt Lake City. The detection limit of ${ }^{3} \mathrm{H}$ was reported to be $0.1 \mathrm{TU}$ and the analytical precision was generally better than $0.2 \mathrm{TU}$ but as high as $0.6 \mathrm{TU}$. Samples for carbon- $14\left({ }^{14} \mathrm{C}\right)$ and stable isotopes of carbon were filtered ( 0.45 micron) and collected in $500-\mathrm{mL}$ or $1-\mathrm{L}$ glass bottles. The bottles were filled from the bottom and allowed to overflow for several volumes in order to rinse the bottles while minimizing contact with the air, sealed with polyseal caps, and analyzed at the National Ocean Sciences Accelerator Mass Spectrometry Facility (NOSAMS) at the Woods Hole Oceanographic Institution in Woods Hole, Massachusetts. Analytical error for ${ }^{14} \mathrm{C}$ was less than $0.5 \mathrm{pmC}$, and for $\delta^{13} \mathrm{C}$ was $0.3 \%$ or better.

Noble-gas samples were collected either as water samples sealed in copper tubes as described by Stute and Schlosser (2000) or as gas samples collected with diffusion samplers similar to those described by Sanford and others (1996) and Gardner and Solomon (2009). The copper tube method consists of attaching a 76-cm-long section of 1-cm-diameter copper tubing to a sampling port at the wellhead, allowing the tube to flush with well water until all air bubbles have been evacuated, then sealing both ends with clamps. The diffusion sampler method was used at wells and springs where either in situ placement or uninterrupted flow using a flowthrough chamber was possible for a minimum of 24 hours. The diffusion sampler is constructed of 30 -millimeter- $(\mathrm{mm})$ diameter copper tubing and a semipermeable gas diffusion membrane. The flow-through chamber is an airtight chamber connected to a discharge point at the wellhead, allowing water to flow through the chamber and past the membrane. After 24 hours, when the gases in the diffusion sampler had equilibrated with the dissolved gases in the sample water, the sampler was removed from the well or spring and immediately sealed. All dissolved-gas concentrations were analyzed by the University of Utah DGSC using both quadrupole and sector-field mass spectrometers. The analysis from copper-tube samples directly provides the concentrations of each gas dissolved in the water sample. Analysis using diffusion samplers provides the relative mole fractions of gases dissolved in a sample; the dissolved-gas concentrations were calculated using Henry's Law relations and field measurements of total dissolved-gas pressure and water temperature. Analytical uncertainties $(1 \sigma)$ for ${ }^{3} \mathrm{He},{ }^{4} \mathrm{He}, \mathrm{Ne}$, $\mathrm{Ar}, \mathrm{Kr}$, and $\mathrm{Xe}$ were 2 percent, 1 percent, 2 percent, 1 percent, 5 percent, and 5 percent, respectively.

Samples for $\mathrm{SF}_{6}$ and CFCs were collected unfiltered in duplicate 1-L amber glass bottles with polyseal cone-lined cap and in triplicate $125-\mathrm{mL}$ glass bottles with a foil-lined cap, respectively. The samples were collected by submerging the bottle and using a short section of copper tubing to fill from the bottom of the bottle to minimize exposure to the atmosphere. Each sample was allowed to overflow for at least three bottle volumes in order to rinse the bottles while minimizing contact with the air as per USGS protocols (https://water.usgs.gov/lab accessed May 21, 2019). All samples were analyzed by the University of Utah DGSC. Analytical error was less than 5 percent for both $\mathrm{SF}_{6}$ and CFCs. 


\section{Major lons and Nutrients}

The concentration of total dissolved solids (TDS) for waters sampled during this study ranged from 116 to $1,270 \mathrm{mg} / \mathrm{L}$ (table 4), and 11 of the sites had dissolved-solids concentrations that exceeded the Environmental Protection Agency (EPA) secondary standard of $500 \mathrm{mg} / \mathrm{L}$ for drinkingwater quality (U.S. Environmental Protection Agency, 2018). Eight of these samples $(2,3,7,10,12,13,17$, and 18) were groundwater samples from wells and springs located within Moab-Spanish Valley, southeast of the town of Moab. Of the remaining three samples, two (22 and 23) were surface-water samples from Pack Creek and one (16) was a groundwater sample from a shallow well located along upper Pack Creek at an altitude of 6,100 ft. Groundwater samples from the GCGA $(1,4,5,6,8,11$, and 19) had dissolved-solids concentrations that ranged from 129 to $213 \mathrm{mg} / \mathrm{L}$. Surface-water samples from two sites along Mill Creek (20 and 21) had dissolvedsolids concentrations of 116 and $137 \mathrm{mg} / \mathrm{L}$, respectively.

Ten of the eleven high-TDS waters $(2,3,7,12,13,16$, $17,18,22$, and 23) also exceeded the EPA secondary standard of $250 \mathrm{mg} / \mathrm{L}$ for sulfate (table 4). One surface-water sample from Pack Creek (22), collected in November 2015, exceeded the EPA secondary standard of $50 \mathrm{mg} / \mathrm{L}$ for manganese with a value of $59.2 \mathrm{mg} / \mathrm{L}$. It is worth noting that a sample collected at the same site in June 2016 , contained only $7.78 \mathrm{mg} / \mathrm{L}$ of manganese. No other samples collected during this study had concentrations exceeding EPA drinking water standards for the constituents analyzed.

When groundwater and surface-water samples from Moab-Spanish Valley are categorized according to their dominant dissolved constituents, most fall along a continuum between calcium-bicarbonate $\left(\mathrm{CaHCO}_{3}\right)$ and calcium-sulfate $\left(\mathrm{CaSO}_{4}\right)$ type waters (fig. 8). Samples collected during this study were plotted on a trilinear diagram along with selected samples previously collected (1933-2011) by the USGS (table 5) and samples collected by Nelson (2017; table 6). These data indicate that GCGA samples constitute a clear $\mathrm{CaHCO}_{3}$ end member and that PCD samples group near the extreme $\mathrm{CaSO}_{4}$-dominant waters. Nearly all VFA and LVFA samples plot somewhere between these groups, indicating the possibility that they represent mixtures of the two. Four LVFA samples that fall outside of this pattern are sodiumchloride- $(\mathrm{NaCl})$ dominant waters that are influenced by the Paradox Formation-derived brine, which underlies the shallow groundwater system beneath the Matheson Wetland adjacent to the Colorado River (Gardner, 2004).

Stiff diagrams plotted on a map of the study area illustrate the spatial patterns of major-ion chemistry (pl. 2). In addition to indicating the chemical water type, the overall size of each stiff diagram is indicative of its dissolved-solids concentration. Groundwater samples from the GCGA (sites 1, 4, 5, 6, 8, 11, H8, H10, H12, H16, H17, H19, H23, and H30; tables 4 and 5 ) are distinctly different from samples representing PCD groundwater (sites 16, 22, H3, H21, H22, and H28; tables 4 and 5), which are considerably higher in dissolved solids, particularly sulfate. The high $\mathrm{SO}_{4}$ in the $\mathrm{PCD}$ end-member waters is likely derived from the dissolution of evaporite minerals associated with the Mancos Shale, which crops out in places and directly underlies much of the Pack Creek drainage above Moab-Spanish Valley (pl. 2).

Stiff diagrams show an evolution of major-ion chemistry moving down Spanish Valley in a southeast-northwest direction, the same general direction of groundwater movement in the valley (pl. 2 and pl. 3). Many of the waters throughout the middle of the valley appear to be similar to the waters located in the Pack Creek drainage above (upgradient of) Moab-Spanish Valley (PCD waters). These waters seem to have experienced some degree of dilution by Glen Canyon Group waters, lowering their dissolved-solids concentration as indicated by the variable overall size of the stiff diagrams. The chemical similarity and direction of groundwater movement derived from the water-level contours indicates that much of the groundwater in Moab-Spanish Valley originated in the upper Pack Creek watershed or as seepage losses from Pack Creek in the upper part of the valley. Farther down-valley, stiff figures show an increase in magnesium content, possibly related to contact with Mesozoic-age shales that are more prominent in that area, particularly along the southwest valley margin (pl. 2). A significant increase in dissolved solids at the low end of the valley is attributed to the influence of Paradox Formation evaporite minerals and Paradox brine that underlies the valley aquifer near the Colorado River (pl. 2). Outcrops of Paradox Formation cap rock can be seen along both sides of the lower valley (pl. 2). Several LFVA samples with higher overall dissolved-solids concentration were omitted from plate 2 to more clearly illustrate the chemical signatures of source waters and groundwater mixing within the aquifer system.

\section{Stable Isotopes}

Stable-isotope compositions of samples collected by the USGS, and VFA and LVFA groundwater samples collected by Nelson (2017), are plotted together for comparison (fig. 9). All groundwater and surface-water samples plot along a trend that approximates the GMWL (Craig, 1961a) or a regional "Utah" meteoric water line defined by Kendall and Coplen (2001), indicating that the waters are of meteoric origin. Stableisotope compositions of all groundwater and surface-water samples (with the exception of Ice Box Canyon, USGS site ID 383626109322401 ) ranged from -113 to $-99 \%$ and from -15.5 to $-13.6 \%$ for $\delta \mathrm{D}$ and $\delta^{18} \mathrm{O}$, respectively (table 4 ). In general, samples sourced from precipitation falling at higher altitudes and (or) during the winter should be isotopically lighter (more negative values) and plot lower and farther to the left along the global and Utah meteoric water lines, whereas samples sourced from precipitation falling at lower altitudes and (or) during the summer should be isotopically heavier (less negative values) and plot higher and farther to the right (fig. 9). Waters with more negative values (isotopically lighter) are said to be more "depleted" because they contain fewer of the heavy stable isotopes. 
Table 4. Field-measured water-quality parameters, stable isotopes of water, and dissolved-ion concentrations measured during the present study in selected samples from wells, springs, and streams in the Spanish Valley study area, Utah.

[See appendix table 1-1 for additional information. Values in red exceed U.S. Environmental Protection Agency secondary standards for drinking water quality. Abbreviations: ID, identification;

USGS, U.S. Geological Survey; ${ }^{\circ} \mathrm{C}$, degrees Celsius; $\mu \mathrm{S} / \mathrm{cm}$, microsiemens per centimeter at 25 degrees Celsius; $\mathrm{mg} / \mathrm{L}$, milligrams per liter; $\delta^{18} \mathrm{O}$, ratio of ratio of oxygen- 18 to oxygen- 16 in sample to ratio of oxygen-18 to oxygen-16 in reference; permil, parts per thousand; $\delta \mathrm{D}$, ratio of ratio of deuterium or hydrogen-2 to hydrogen- 1 in sample to ratio of deuterium or hydrogen- 2 to hydrogen-1 in reference; $\mathrm{CaCO}_{3}$, calcium carbonate; $\mathrm{SiO}_{2}$, silicon dioxide; $\mu \mathrm{g} / \mathrm{L}$, micrograms per liter; $<$, less than; - , no data]

\begin{tabular}{|c|c|c|c|c|c|c|c|c|c|c|c|c|}
\hline Sample ID & USGS site number & $\begin{array}{l}\text { Sample date } \\
\text { (mm/dd/yyyy) }\end{array}$ & $\begin{array}{c}\text { Water } \\
\text { temperature } \\
\left({ }^{\circ} \mathrm{C}\right)\end{array}$ & $\begin{array}{c}\mathrm{pH} \\
\text { (standard } \\
\text { units) }\end{array}$ & 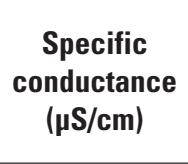 & $\begin{array}{l}\text { Dissolved } \\
\text { oxygen } \\
\text { (mg/L) }\end{array}$ & $\begin{array}{c}\delta^{180} 0 \\
\text { (permil) }\end{array}$ & $\begin{array}{c}\delta D \\
\text { (permil) }\end{array}$ & $\begin{array}{c}\text { Total } \\
\text { dissolved } \\
\text { solids } \\
\text { (mg/L) }\end{array}$ & $\begin{array}{c}\text { Alkalinity } \\
\text { (mg/L) as } \\
\mathrm{CaCO}_{3}\end{array}$ & $\begin{array}{l}\text { Calcium } \\
\text { (mg/L) }\end{array}$ & $\begin{array}{l}\text { Magnesium } \\
(\mathrm{mg} / \mathrm{L})\end{array}$ \\
\hline 1 & 383545109335701 & $05 / 11 / 2015$ & 17.6 & 7.5 & 297 & 6.6 & -15.3 & -111 & 176 & 106 & 29.3 & 12.3 \\
\hline 2 & 383238109302501 & $05 / 11 / 2015$ & 14.9 & 6.9 & 1,650 & 4.5 & -14.4 & -106 & 1,270 & 173 & 181 & 61.7 \\
\hline 3 & 383148109292201 & $05 / 11 / 2015$ & 15.0 & 6.8 & 958 & 0.7 & -14.2 & -105 & 674 & 204 & 116 & 35.4 \\
\hline 4 & 383224109284701 & $05 / 12 / 2015$ & 15.5 & 7.8 & 260 & 8.4 & -15.3 & -111 & 160 & 100 & 32.1 & 11.2 \\
\hline 5 & 383224109294401 & $05 / 12 / 2015$ & 15.2 & 7.6 & 348 & 7.2 & -15.2 & -110 & 223 & 118 & 41.2 & 14.9 \\
\hline 5 (replicate) & 383224109294401 & $05 / 12 / 2015$ & - & - & - & - & -15.2 & -110 & 217 & 118 & 41.6 & 15.3 \\
\hline 6 & 383149109284601 & $05 / 12 / 2015$ & 15.4 & 7.8 & 278 & 8.2 & -15.2 & -110 & 185 & 99.1 & 32.4 & 12.1 \\
\hline 7 & 383312109322701 & $05 / 12 / 2015$ & 15.8 & 7.4 & 992 & 7.9 & -15.0 & -110 & 760 & 141 & 105 & 49.0 \\
\hline 8 & 383312109263501 & $05 / 12 / 2015$ & 12.6 & 7.5 & 222 & 6.9 & -15.5 & -113 & 141 & 96.5 & 23.9 & 11.7 \\
\hline 9 & 383457109245401 & $05 / 13 / 2015$ & 15.0 & 7.3 & 370 & 6.4 & -13.9 & -106 & 223 & 180 & 49.5 & 17.2 \\
\hline 10 & 383043109282401 & 05/13/2015 & 15.7 & 7.0 & 862 & 8.2 & -13.8 & -103 & 594 & 198 & 99.0 & 32.0 \\
\hline 11 & 383113109281201 & $05 / 13 / 2015$ & 16.1 & 7.8 & 337 & 8.3 & -15.1 & -110 & 213 & 109 & 36.9 & 14.4 \\
\hline 12 & 383340109314301 & 05/13/2015 & 16.5 & 7.1 & 1,170 & 7.2 & -14.6 & -107 & 875 & 206 & 140 & 50.3 \\
\hline 13 & 382849109255901 & $05 / 14 / 2015$ & 17.3 & 7.3 & 855 & 8.4 & -14.9 & -108 & 613 & 154 & 116 & 23.2 \\
\hline 14 & 383026109200301 & $06 / 16 / 2015$ & 9.0 & 6.3 & 682 & 0.1 & -15.2 & -113 & 453 & 233 & 82.3 & 20.1 \\
\hline 15 & 383308109224601 & $06 / 15 / 2015$ & 15.0 & 7.3 & 300 & 0.0 & -15.4 & -111 & 176 & 127 & 34.9 & 18.1 \\
\hline 16 & 382621109214001 & $06 / 15 / 2015$ & 11.5 & 6.7 & 1,120 & 6.2 & -15.0 & -109 & 853 & 168 & 174 & 32.4 \\
\hline 17 & 382929109272101 & $06 / 16 / 2015$ & 17.0 & 6.9 & 1,080 & 6.9 & -14.7 & -107 & 812 & 144 & 158 & 31.4 \\
\hline 18 & 383024109283801 & $06 / 17 / 2015$ & 17.5 & 6.9 & 980 & 5.3 & -14.9 & -109 & 734 & 146 & 143 & 30.2 \\
\hline 19 & 383537109303001 & $11 / 19 / 2015$ & - & 7.9 & 222 & - & -15.3 & -112 & 129 & 103 & 25.7 & 12.3 \\
\hline 20 & 382959109182501 & $11 / 18 / 2015$ & - & 7.9 & 175 & - & -14.9 & -107 & 116 & 78.8 & 28.9 & 4.88 \\
\hline 21 & 09184000 & $06 / 17 / 2015$ & 21.5 & 8.0 & 222 & 6.7 & -14.4 & -105 & 137 & 105 & 31.6 & 9.27 \\
\hline 22 & 382645109230701 & $06 / 16 / 2015$ & 13.3 & 7.8 & 310 & 9.7 & -14.3 & -101 & 202 & 75.5 & 47.9 & 6.59 \\
\hline 22 & 382645109230701 & $11 / 18 / 2015$ & - & 7.8 & 1,270 & - & -14.9 & -108 & 1,010 & 157 & 213 & 36.3 \\
\hline 23 & 383414109331701 & $11 / 20 / 2015$ & - & 7.8 & 1,390 & - & -14.1 & -104 & 1,070 & 206 & 168 & 59.6 \\
\hline \multicolumn{9}{|c|}{ U.S. Environmental Protection Agency secondary standard } & 500 & & & \\
\hline
\end{tabular}


Table 4. Field-measured water-quality parameters, stable isotopes of water, and dissolved-ion concentrations measured during the present study in selected samples from wells, springs, and streams in the Spanish Valley study area, Utah.-Continued

[See appendix table 1-1 for additional information. Values in red exceed U.S. Environmental Protection Agency secondary standards for drinking water quality. Abbreviations: ID, identification;

USGS, U.S. Geological Survey; ${ }^{\circ} \mathrm{C}$, degrees Celsius; $\mu \mathrm{S} / \mathrm{cm}$, microsiemens per centimeter at 25 degrees Celsius; $\mathrm{mg} / \mathrm{L}$, milligrams per liter; $\delta^{18} \mathrm{O}$, ratio of ratio of oxygen-18 to oxygen- 16 in sample to ratio of oxygen-18 to oxygen-16 in reference; permil, parts per thousand; $\delta \mathrm{D}$, ratio of ratio of deuterium or hydrogen- 2 to hydrogen-1 in sample to ratio of deuterium or hydrogen- 2 to hydrogen-1 in reference; $\mathrm{CaCO}$, calcium carbonate; $\mathrm{SiO}_{2}$, silicon dioxide; $\mu \mathrm{g} / \mathrm{L}$, micrograms per liter; $<$, less than; - , no data]

\begin{tabular}{|c|c|c|c|c|c|c|c|c|c|c|c|c|}
\hline Sample ID & USGS site number & $\begin{array}{l}\text { Sample date } \\
\text { (mm/dd/yyyy) }\end{array}$ & $\begin{array}{c}\text { Sodium } \\
\text { (mg/L) }\end{array}$ & $\begin{array}{l}\text { Potassium } \\
\text { (mg/L) }\end{array}$ & $\begin{array}{c}\text { Chloride } \\
\text { (mg/L) }\end{array}$ & $\begin{array}{l}\text { Sulfate } \\
\text { (mg/L) }\end{array}$ & $\begin{array}{c}\text { Silica } \\
\text { (mg/L) } \\
\text { as } \mathrm{SiO}_{2}\end{array}$ & $\begin{array}{c}\text { Fluoride } \\
\text { (mg/L) }\end{array}$ & $\begin{array}{c}\text { Bromide } \\
\text { (mg/L) }\end{array}$ & $\begin{array}{l}\text { Iron, water } \\
(\mu \mathrm{g} / \mathrm{L})\end{array}$ & $\begin{array}{c}\text { Manganese } \\
(\mu \mathrm{g} / \mathrm{L})\end{array}$ & $\begin{array}{c}\text { Nitrate plus } \\
\text { nitrite (mg/L) } \\
\text { as nitrogen }\end{array}$ \\
\hline 1 & 383545109335701 & $05 / 11 / 2015$ & 11.7 & 1.53 & 9.48 & 32.8 & 9.20 & 0.15 & $<0.030$ & $<4.0$ & $<0.20$ & 0.215 \\
\hline 2 & 383238109302501 & $05 / 11 / 2015$ & 114 & 3.54 & 51.0 & 665 & 15.5 & 0.27 & 0.292 & 13.3 & $<0.20$ & 4.230 \\
\hline 3 & 383148109292201 & $05 / 11 / 2015$ & 45.9 & 2.54 & 22.2 & 281 & 15.0 & 0.23 & 0.122 & 43.5 & 5.13 & 3.620 \\
\hline 4 & 383224109284701 & $05 / 12 / 2015$ & 5.78 & 1.07 & 1.71 & 35.7 & 9.20 & 0.13 & $<0.030$ & $<4.0$ & $<0.20$ & 0.237 \\
\hline 5 & 383224109294401 & $05 / 12 / 2015$ & 9.62 & 1.22 & 5.92 & 58.6 & 9.90 & 0.12 & 0.031 & $<4.0$ & $<0.20$ & 0.375 \\
\hline 5 (replicate) & 383224109294401 & $05 / 12 / 2015$ & 9.81 & 1.26 & 5.91 & 58.6 & 9.90 & 0.12 & 0.032 & $<4.0$ & $<0.20$ & 0.436 \\
\hline 6 & 383149109284601 & $05 / 12 / 2015$ & 8.04 & 1.19 & 2.92 & 42.9 & 9.40 & 0.14 & $<0.030$ & $<4.0$ & $<0.20$ & 0.221 \\
\hline 7 & 383312109322701 & $05 / 12 / 2015$ & 45.5 & 2.80 & 17.9 & 383 & 12.4 & 0.45 & 0.071 & 4.6 & $<0.20$ & 1.49 \\
\hline 8 & 383312109263501 & $05 / 12 / 2015$ & 4.87 & 0.82 & 2.37 & 17.3 & 7.50 & 0.11 & $<0.030$ & $<4.0$ & $<0.20$ & 0.340 \\
\hline 9 & 383457109245401 & $05 / 13 / 2015$ & 5.72 & 1.59 & 7.78 & 13.6 & 10.1 & 0.21 & 0.088 & $<4.0$ & $<0.20$ & 0.509 \\
\hline 10 & 383043109282401 & $05 / 13 / 2015$ & 43.7 & 2.65 & 24.5 & 223 & 14.6 & 0.18 & 0.145 & 16.5 & 0.35 & 3.84 \\
\hline 11 & 383113109281201 & $05 / 13 / 2015$ & 12.2 & 1.37 & 7.06 & 57.8 & 10.0 & 0.17 & $<0.030$ & 4.0 & $<0.20$ & 0.354 \\
\hline 12 & 383340109314301 & $05 / 13 / 2015$ & 52.9 & 3.21 & 41.1 & 397 & 16.4 & 0.39 & 0.137 & 49.9 & 5.33 & 1.96 \\
\hline 13 & 382849109255901 & $05 / 14 / 2015$ & 41.2 & 1.98 & 8.46 & 297 & 13.2 & 0.32 & $<0.060$ & 17.5 & 1.06 & 0.449 \\
\hline 14 & 383026109200301 & $06 / 16 / 2015$ & 48.3 & 3.10 & 5.23 & 145 & 14.8 & 0.24 & 0.072 & 63.9 & 36.6 & $<0.04$ \\
\hline 15 & 383308109224601 & $06 / 15 / 2015$ & 2.79 & 1.80 & 0.79 & 33.7 & 9.60 & 0.25 & $<0.030$ & 42.6 & 36.0 & $<0.04$ \\
\hline 16 & 382621109214001 & $06 / 15 / 2015$ & 43.9 & 2.00 & 11.2 & 443 & 19.4 & 0.74 & $<0.060$ & 12.7 & 0.37 & 0.129 \\
\hline 17 & 382929109272101 & $06 / 16 / 2015$ & 47.6 & 2.77 & 17.5 & 416 & 12.0 & 0.30 & 0.140 & 7.1 & 0.23 & 3.32 \\
\hline 18 & 383024109283801 & $06 / 17 / 2015$ & 43.8 & 2.21 & 14.8 & 369 & 13.9 & 0.39 & $<0.060$ & 49.5 & 3.09 & 0.822 \\
\hline 19 & 383537109303001 & $11 / 19 / 2015$ & 3.17 & 1.01 & 1.94 & 12.3 & 7.75 & 0.13 & 0.020 & $<4.0$ & $<0.20$ & 0.380 \\
\hline 20 & 382959109182501 & $11 / 18 / 2015$ & 2.39 & 0.57 & 0.80 & 13.7 & 8.28 & 0.28 & $<0.010$ & 4.4 & 1.30 & 0.236 \\
\hline 21 & 09184000 & $06 / 17 / 2015$ & 3.97 & 0.95 & 1.62 & 12.7 & 7.50 & 0.15 & $<0.030$ & 21.4 & 13.3 & 0.080 \\
\hline 22 & 382645109230701 & $06 / 16 / 2015$ & 8.30 & 0.72 & 2.19 & 77.6 & 8.40 & 0.15 & $<0.030$ & 17.0 & 7.73 & 0.100 \\
\hline 22 & 382645109230701 & $11 / 18 / 2015$ & 53.2 & 2.41 & 14.3 & 553 & 17.9 & 0.77 & $<0.030$ & $<16.0$ & 59.2 & 0.044 \\
\hline 23 & 383414109331701 & $11 / 20 / 2015$ & 80.6 & 4.48 & 39.8 & 505 & 15.8 & 0.40 & 0.193 & 12.6 & 15.0 & 1.65 \\
\hline \multicolumn{5}{|c|}{ U.S. Environmental Protection Agency secondary standard } & 250 & 250 & & 2 & & 300 & 50 & \\
\hline
\end{tabular}




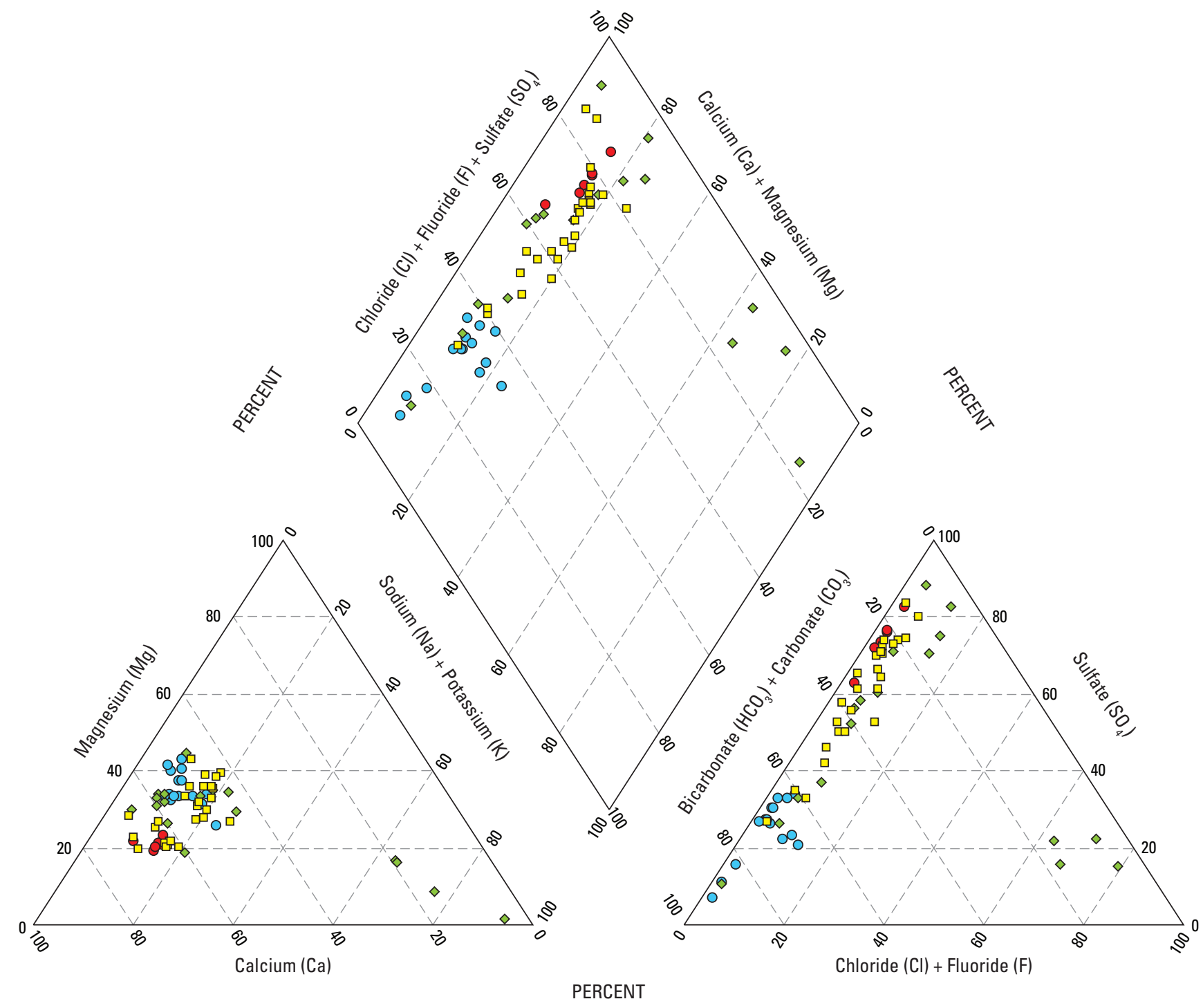

EXPLANATION

- Glen Canyon Group aquifer groundwater

- Pack Creek drainage groundwater

$\square$ Valley-fill aquifer groundwater

$\diamond$ Lower valley-fill aquifer groundwater

Figure 8. Major-ion composition of selected samples from wells, springs, and one stream (at base flow) in the Spanish Valley study area, Utah. 
Table 5. Historical (1933-2011) field-measured water-quality parameters and dissolved-ion concentrations in selected samples from wells, springs, and streams in the Spanish Valley study area, Utah.

[Abbreviations: ID, identification; USGS, U.S. Geological Survey; ${ }^{\circ} \mathrm{C}$, degrees Celsius; $\mu \mathrm{S} / \mathrm{cm}$, microsiemens per centimeter at 25 degrees Celsius; $\mathrm{mg} / \mathrm{L}$, milligrams per liter; $\mathrm{HCO}_{3}^{-}$, bicarbonate; $\mathrm{SiO}_{2}$, silicon dioxide; $\mu \mathrm{g} / \mathrm{L}$, micrograms per liter; —, no data]

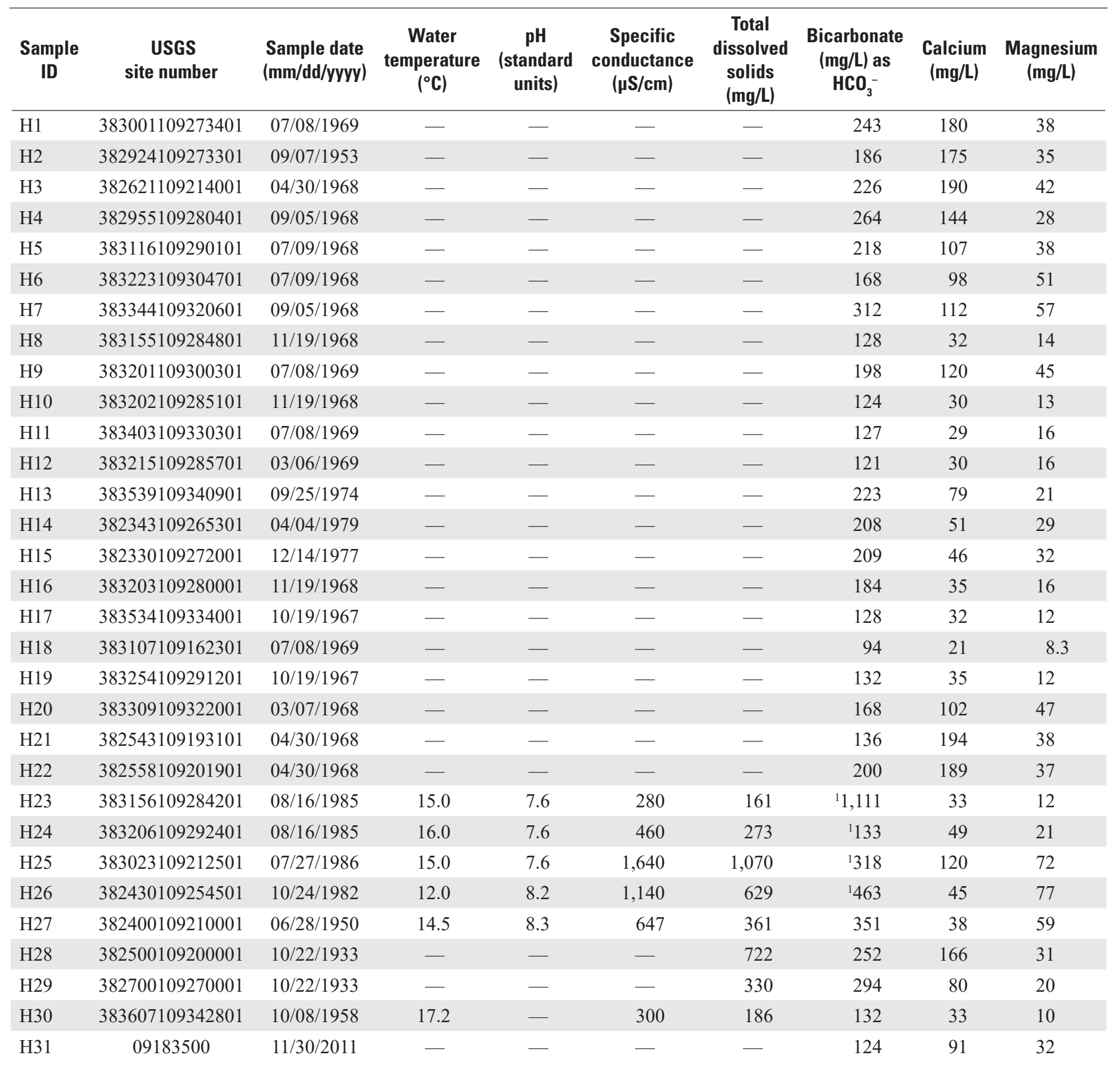


Table 5. Historical (1933-2011) field-measured water-quality parameters and dissolved-ion concentrations in selected samples from wells, springs, and streams in the Spanish Valley study area, Utah.-Continued

[Abbreviations: ID, identification; USGS, U.S. Geological Survey; ${ }^{\circ} \mathrm{C}$, degrees Celsius; $\mu \mathrm{S} / \mathrm{cm}$, microsiemens per centimeter at 25 degrees Celsius; mg/L, milligrams per liter; $\mathrm{HCO}_{3}^{-}$, bicarbonate; $\mathrm{SiO}_{2}$, silicon dioxide; $\mu \mathrm{g} / \mathrm{L}$, micrograms per liter; -, no data]

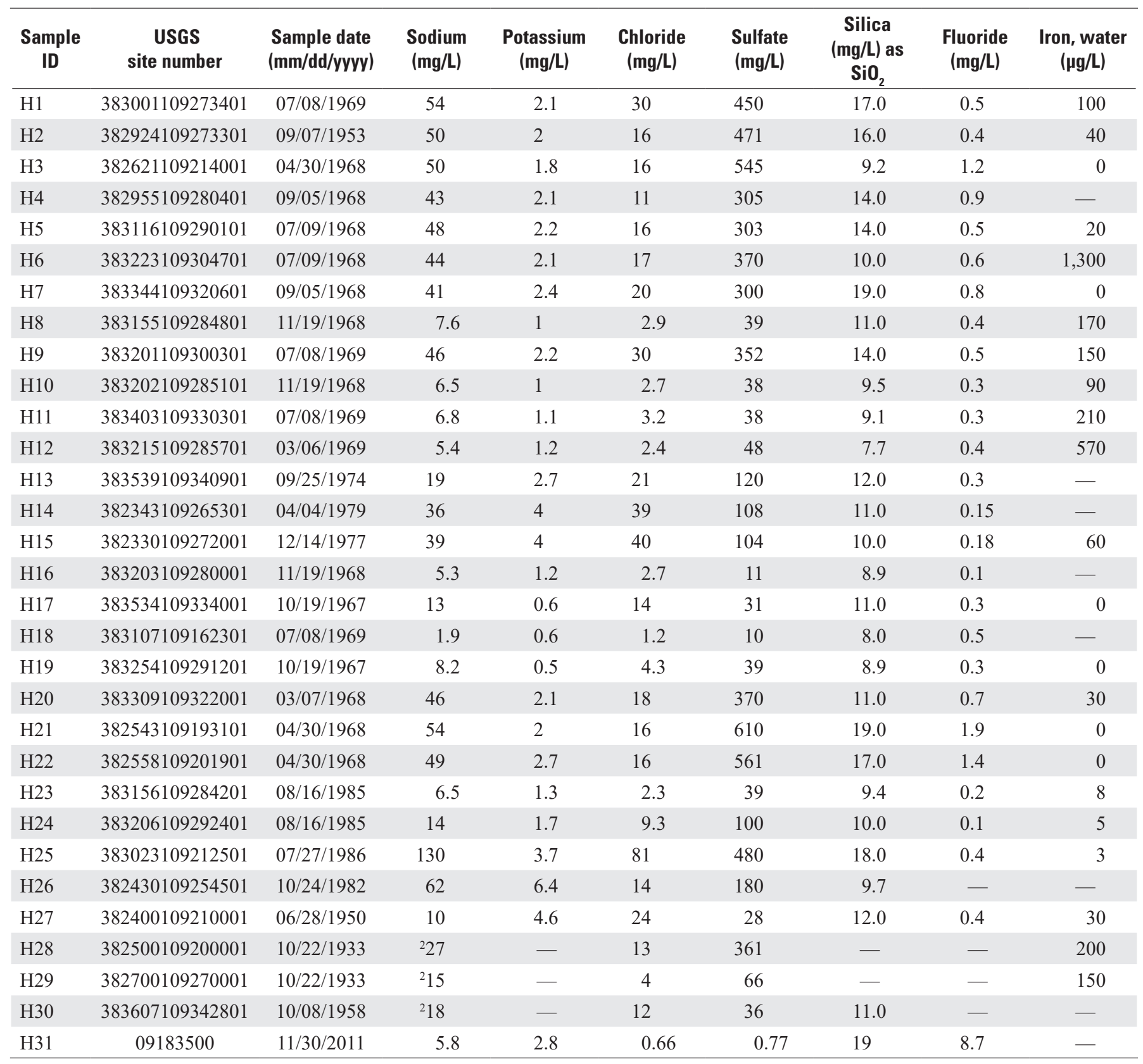

${ }^{1}$ Bicarbonate estimated as 1.19 multiplied by laboratory reported acid neutralizing capacity.

${ }^{2}$ Value reported as the sum of sodium plus potassium; potassium is assumed to be less than 10 percent of this sum. 
Table 6. Field-measured water-quality parameters, stable isotopes of water, and dissolved-ion concentrations of selected groundwater samples measured by Nelson (2017) in the lower part of the Spanish Valley study area, Utah.

[See appendix table 1-1 for additional information. Abbreviations: ID, identification; USGS, U.S. Geological Survey; ${ }^{\circ} \mathrm{C}$, degrees Celsius; $\mu \mathrm{S} / \mathrm{cm}$, microsiemens per centimeter at 25 degrees Celsius; $\mathrm{mg} / \mathrm{L}$, milligrams per liter; $\delta^{18} \mathrm{O}$, ratio of ratio of oxygen- 18 to oxygen- 16 in sample to ratio of oxygen-18 to oxygen-16 in reference; permil, parts per thousand; $\delta \mathrm{D}$, ratio of ratio of deuterium or hydrogen-2 to hydrogen- 1 in sample to ratio of deuterium or hydrogen- 2 to hydrogen-1 in reference; $\mathrm{HCO}_{3}^{-}$, bicarbonate; ODL, over detection limit]

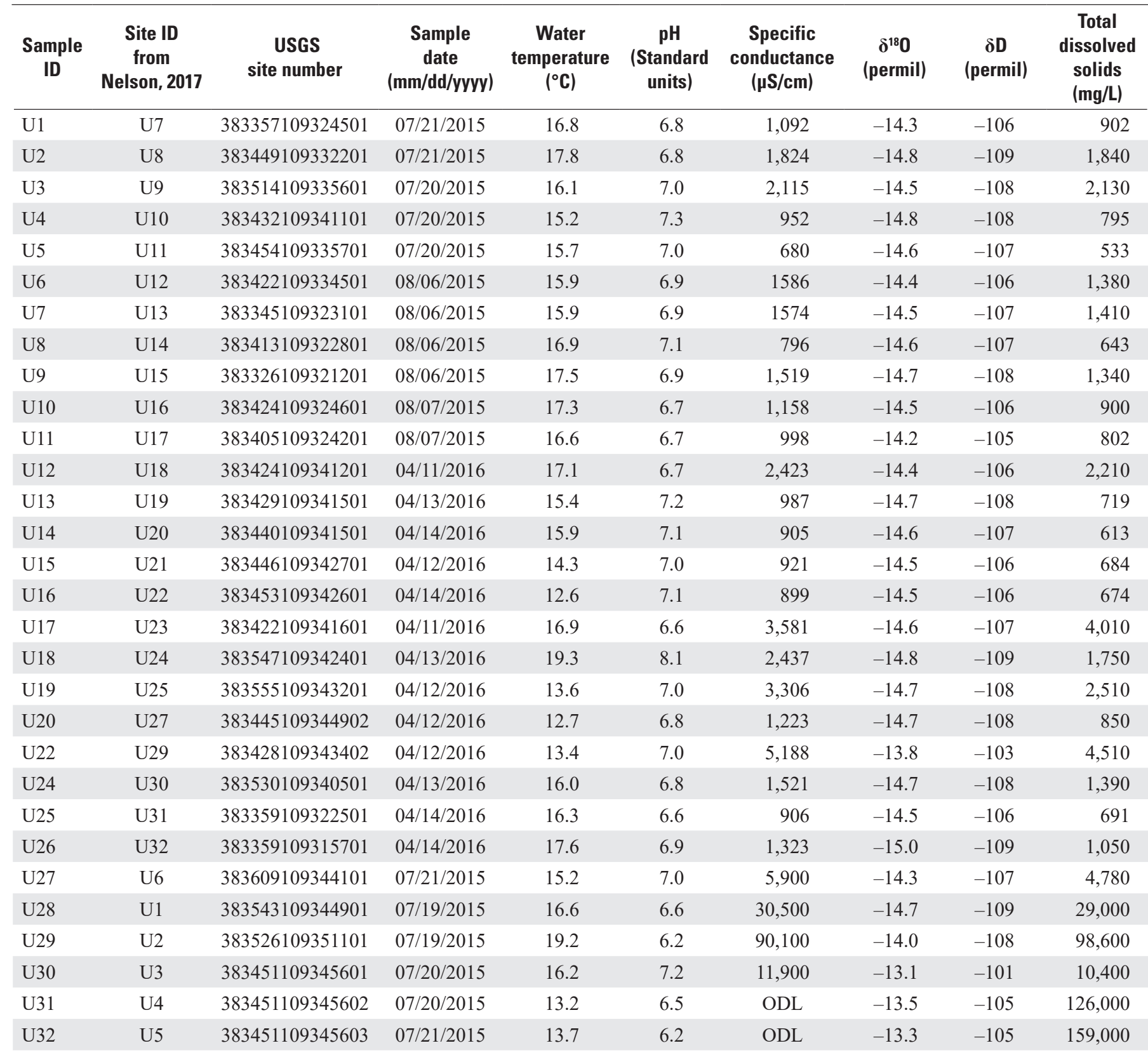


Table 6. Field-measured water-quality parameters, stable isotopes of water, and dissolved-ion concentrations of selected groundwater samples measured by Nelson (2017) in the lower part of the Spanish Valley study area, Utah.—Continued

[See appendix table 1-1 for additional information. Abbreviations: ID, identification; USGS, U.S. Geological Survey; ${ }^{\circ} \mathrm{C}$, degrees Celsius; $\mu \mathrm{S} / \mathrm{cm}$, microsiemens per centimeter at 25 degrees Celsius; $\mathrm{mg} / \mathrm{L}$, milligrams per liter; $\delta^{18} \mathrm{O}$, ratio of ratio of oxygen- 18 to oxygen- 16 in sample to ratio of oxygen- 18 to oxygen-16 in reference; permil, parts per thousand; $\delta \mathrm{D}$, ratio of ratio of deuterium or hydrogen-2 to hydrogen-1 in sample to ratio of deuterium or hydrogen-2 to hydrogen-1 in reference; $\mathrm{HCO}_{3}$; bicarbonate; $\mathrm{ODL}$, over detection limit]

\begin{tabular}{|c|c|c|c|c|c|c|c|c|c|c|}
\hline $\begin{array}{l}\text { Sample } \\
\text { ID }\end{array}$ & $\begin{array}{c}\text { Site ID } \\
\text { from } \\
\text { Nelson, } 2017\end{array}$ & $\begin{array}{c}\text { USGS } \\
\text { site number }\end{array}$ & $\begin{array}{c}\text { Sample } \\
\text { date } \\
\text { (mm/dd/yyyy) }\end{array}$ & $\begin{array}{c}\text { Bicarbonate } \\
\text { (mg/L) as } \\
\mathrm{HCO}_{3}^{-}\end{array}$ & $\begin{array}{c}\text { Calcium } \\
\text { (mg/L) }\end{array}$ & $\begin{array}{l}\text { Magnesium } \\
(\mathrm{mg} / \mathrm{L})\end{array}$ & $\begin{array}{l}\text { Sodium } \\
\text { (mg/L) }\end{array}$ & $\begin{array}{l}\text { Potassium } \\
\text { (mg/L) }\end{array}$ & $\begin{array}{l}\text { Chloride } \\
\text { (mg/L) }\end{array}$ & $\begin{array}{l}\text { Sulfate } \\
(\mathrm{mg} / \mathrm{L})\end{array}$ \\
\hline U1 & U7 & 383357109324501 & $07 / 21 / 2015$ & 329 & 173 & 42 & 36 & 3 & 28 & 292 \\
\hline $\mathrm{U} 2$ & U8 & 383449109332201 & $07 / 21 / 2015$ & 237 & 325 & 82 & 27 & 4 & 32 & 1,130 \\
\hline U3 & U9 & 383514109335601 & $07 / 20 / 2015$ & 151 & 382 & 106 & 30 & 4 & 54 & 1,410 \\
\hline U4 & $\mathrm{U} 10$ & 383432109341101 & $07 / 20 / 2015$ & 257 & 142 & 45 & 23 & 2 & 24 & 302 \\
\hline U5 & U11 & 383454109335701 & $07 / 20 / 2015$ & 366 & 71 & 41 & 13 & 2 & 5 & 36 \\
\hline U6 & U12 & 383422109334501 & $08 / 06 / 2015$ & 285 & 181 & 82 & 79 & 4 & 48 & 704 \\
\hline U7 & U13 & 383345109323101 & $08 / 06 / 2015$ & 263 & 204 & 78 & 59 & 4 & 48 & 754 \\
\hline U8 & U14 & 383413109322801 & $08 / 06 / 2015$ & 278 & 86 & 39 & 32 & 3 & 24 & 181 \\
\hline U9 & U15 & 383326109321201 & 08/06/2015 & 263 & 175 & 72 & 79 & 6 & 42 & 701 \\
\hline U10 & U16 & 383424109324601 & 08/07/2015 & 280 & 114 & 64 & 53 & 5 & 58 & 326 \\
\hline U11 & U17 & 383405109324201 & 08/07/2015 & 383 & 162 & 28 & 29 & 3 & 32 & 167 \\
\hline U12 & U18 & 383424109341201 & $04 / 11 / 2016$ & 232 & 274 & 111 & 179 & 6 & 170 & 1,240 \\
\hline U13 & U19 & 383429109341501 & $04 / 13 / 2016$ & 219 & 127 & 43 & 24 & 2 & 22 & 281 \\
\hline U14 & U20 & 383440109341501 & $04 / 14 / 2016$ & 206 & 117 & 42 & 17 & 2 & 22 & 209 \\
\hline U15 & $\mathrm{U} 21$ & 383446109342701 & $04 / 12 / 2016$ & 333 & 124 & 42 & 19 & 2 & 21 & 143 \\
\hline U16 & $\mathrm{U} 22$ & 383453109342601 & $04 / 14 / 2016$ & 363 & 116 & 42 & 20 & 2 & 19 & 112 \\
\hline U17 & $\mathrm{U} 23$ & 383422109341601 & $04 / 11 / 2016$ & 206 & 601 & 114 & 234 & 7 & 283 & 2,560 \\
\hline U18 & $\mathrm{U} 24$ & 383547109342401 & $04 / 13 / 2016$ & 298 & 23 & 5 & 506 & 4 & 696 & 219 \\
\hline U19 & $\mathrm{U} 25$ & 383555109343201 & $04 / 12 / 2016$ & 378 & 143 & 74 & 544 & 9 & 925 & 440 \\
\hline $\mathrm{U} 20$ & $\mathrm{U} 27$ & 383445109344902 & $04 / 12 / 2016$ & 223 & 136 & 55 & 49 & 5 & 36 & 345 \\
\hline $\mathrm{U} 22$ & $\mathrm{U} 29$ & 383428109343402 & $04 / 12 / 2016$ & 263 & 195 & 68 & 1,100 & 13 & 2,260 & 605 \\
\hline $\mathrm{U} 24$ & $\mathrm{U} 30$ & 383530109340501 & $04 / 13 / 2016$ & 166 & 260 & 52 & 37 & 3 & 56 & 816 \\
\hline $\mathrm{U} 25$ & U31 & 383359109322501 & $04 / 14 / 2016$ & 335 & 125 & 33 & 27 & 2 & 17 & 152 \\
\hline U26 & U32 & 383359109315701 & $04 / 14 / 2016$ & 151 & 139 & 66 & 75 & 6 & 78 & 538 \\
\hline $\mathrm{U} 27$ & U6 & 383609109344101 & $07 / 21 / 2015$ & 327 & 237 & 128 & 905 & 12 & 2,220 & 951 \\
\hline $\mathrm{U} 28$ & U1 & 383543109344901 & 07/19/2015 & 311 & 1,120 & 206 & 6,650 & 67 & 19,900 & 683 \\
\hline U29 & $\mathrm{U} 2$ & 383526109351101 & 07/19/2015 & 227 & 2,620 & 693 & 24,300 & 179 & 66,300 & 4,270 \\
\hline $\mathrm{U} 30$ & U3 & 383451109345601 & $07 / 20 / 2015$ & 366 & 202 & 68 & 2,550 & 52 & 6,260 & 882 \\
\hline U31 & U4 & 383451109345602 & $07 / 20 / 2015$ & 317 & 1,910 & 554 & 32,400 & 667 & 84,900 & 5,350 \\
\hline U32 & U5 & 383451109345603 & $07 / 21 / 2015$ & 201 & 1,980 & 664 & 41,100 & 969 & 108,000 & 6,140 \\
\hline
\end{tabular}




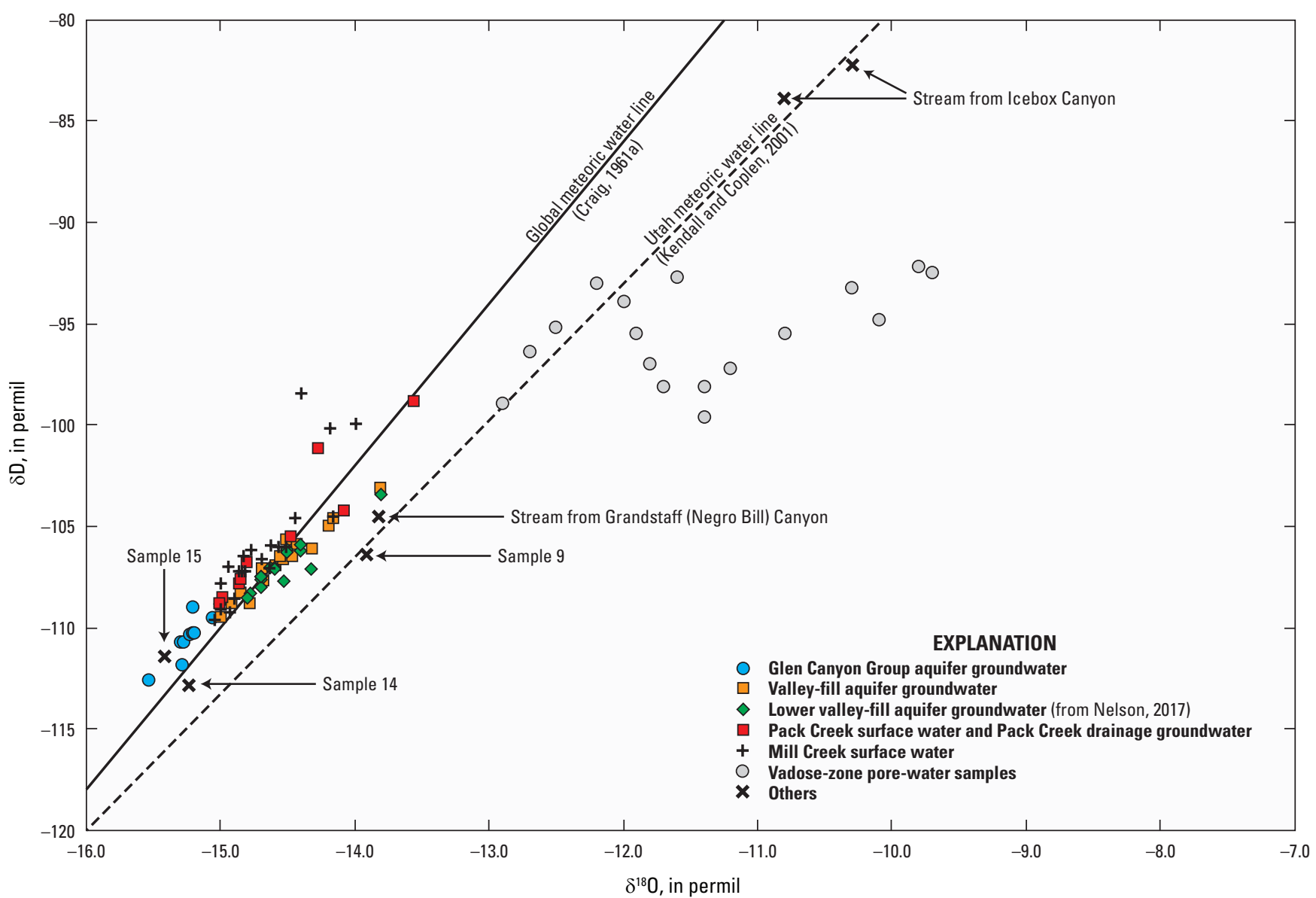

Figure 9. Stable-isotope values of water samples collected during this study and by Nelson (2017) in the Spanish Valley study area, Utah.

Waters representing the GCGA are isotopically lighter than most other waters. All GCGA samples had $\delta \mathrm{D}$ and $\delta^{18} \mathrm{O}$ values of less than -109 and $-15.0 \%$, respectively, indicating that high-altitude precipitation is the source of recharge to this aquifer. Two other samples that fall into this isotopic category were 14 and 15 (fig. 9). Even though these sites may not be hydraulically connected to the GCGA, their location in the watershed (altitudes of between 7,000 and 8,000 ft) ensures that they represent recharge from high-altitude precipitation.
Waters representing the PCD group of samples had values ranging from -109 to $-99 \%$ and -15.0 to $-13.6 \%$ for $\delta \mathrm{D}$ and $\delta^{18} \mathrm{O}$, respectively, indicating that high-altitude precipitation is the source for some, but not all, of these samples. Furthermore, the most depleted PCD samples did not overlap with the least depleted GCGA samples, indicating that a distinctly higher-altitude catchment is the source of the recharge to the GCGA. The PCD group spans nearly the same isotopic range with respect to $\delta \mathrm{D}$ and $\delta^{18} \mathrm{O}$ as all samples representing VFA and LVFA groundwaters (tables 4 and 6), and all samples of Mill Creek surface water (table 7). 
Table 7. Field-measured water-quality parameters and stable isotopes of water from selected stream sites in the Spanish Valley study area, Utah.

[See appendix table 1-1 for additional information. Abbreviations: USGS, U.S. Geological Survey; ft, feet; ${ }^{\circ} \mathrm{C}$, degrees Celsius; $\mu \mathrm{S} / \mathrm{cm}$, microsiemens per centimeter at 25 degrees Celsius; $\delta^{18} \mathrm{O}$, ratio of ratio of oxygen-18 to oxygen-16 in sample to ratio of oxygen-18 to oxygen-16 in reference; permil, parts per thousand; $\delta \mathrm{D}$, ratio of ratio of deuterium or hydrogen-2 to hydrogen-1 in sample to ratio of deuterium or hydrogen-2 to hydrogen-1 in reference; - , no data]

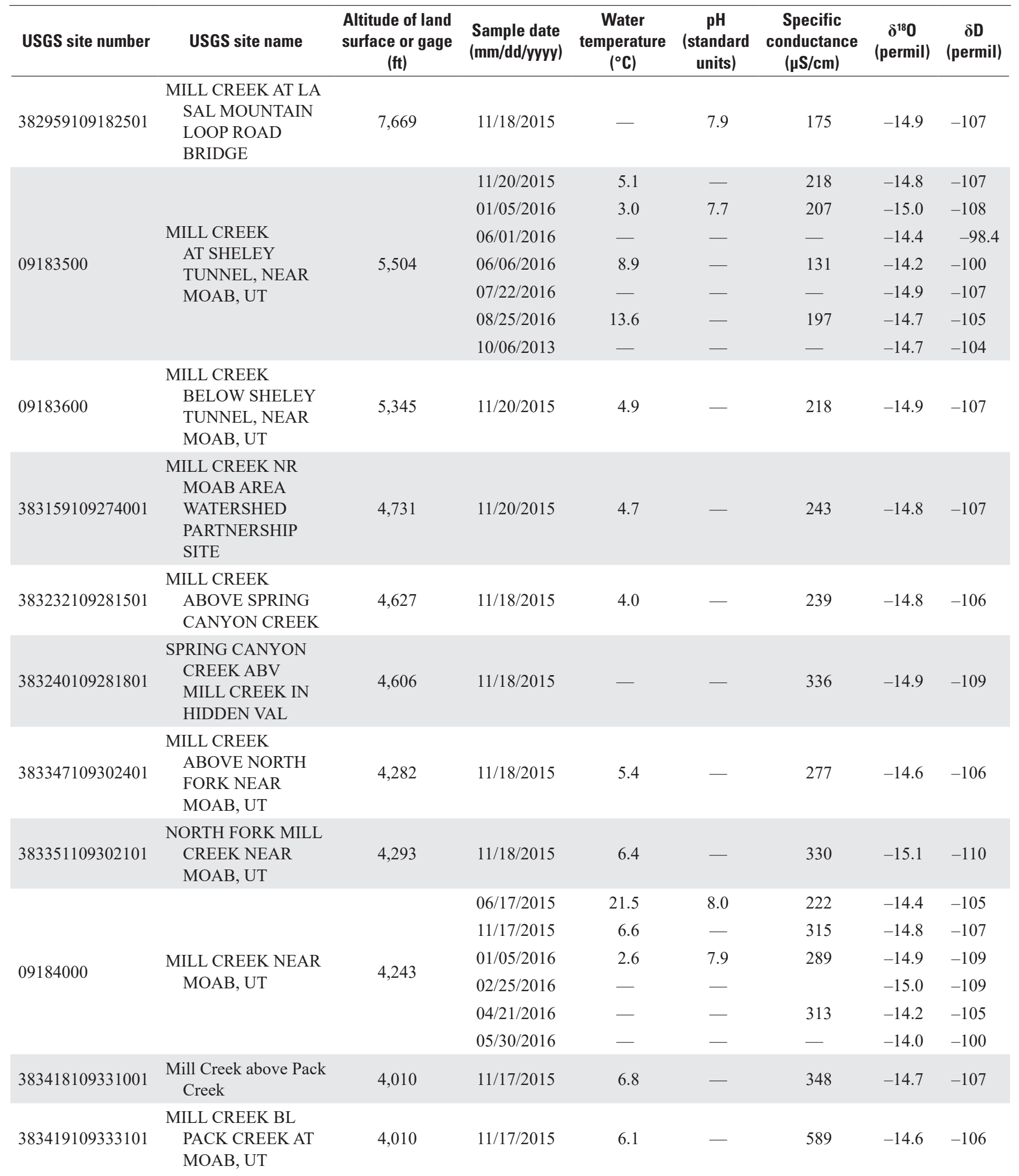


Table 7. Field-measured water-quality parameters and stable isotopes of water from selected stream sites in the Spanish Valley study area, Utah.-Continued

[See appendix table 1-1 for additional information. Abbreviations: USGS, U.S. Geological Survey; ft, feet; ${ }^{\circ} \mathrm{C}$, degrees Celsius; $\mu \mathrm{S} / \mathrm{cm}$, microsiemens per centimeter at 25 degrees Celsius; $\delta^{18} \mathrm{O}$, ratio of ratio of oxygen-18 to oxygen-16 in sample to ratio of oxygen-18 to oxygen-16 in reference; permil, parts per thousand; $\delta \mathrm{D}$, ratio of ratio of deuterium or hydrogen-2 to hydrogen-1 in sample to ratio of deuterium or hydrogen-2 to hydrogen- 1 in reference; - , no data]

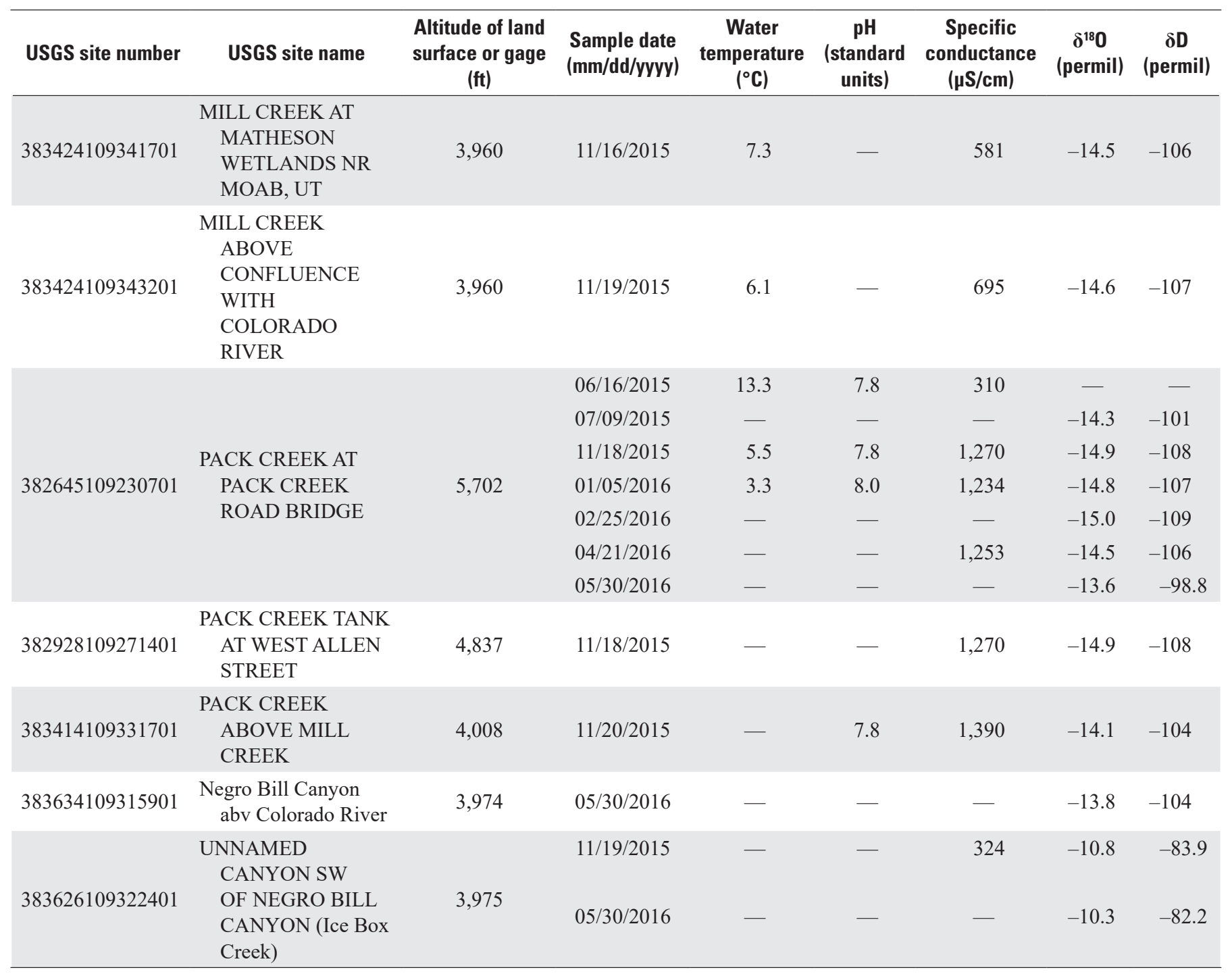

Samples from a spring high on Sand Flats road (sample 9, table 4) and from Negro Bill Wash (table 7) had $\delta \mathrm{D}$ values of -106 and $-104 \%$ and $\delta^{18} \mathrm{O}$ values of -13.9 and $-13.8 \%$, respectively. These samples were both collected within or along the edge of the Negro Bill Canyon watershed that originates at around $7,000 \mathrm{ft}$, where it abuts the steep escarpment that forms the southwest margin of Castle Valley (pl. 2). These samples may represent the value of the bulk precipitation that directly recharges approximately the northern third of the Glen Canyon Group-capped mesa northeast of Moab-Spanish Valley, specifically the area between the Negro Bill Canyon watershed and the northwesttrending margin of the Glen Canyon Group mesa that abuts Castle Valley. The isotope values from the Negro Bill Canyon surface-water sample indicate that groundwater in this section of Glen Canyon Group rocks drains into Negro Bill Canyon to supply base flow. This assumption is based on only one sample from May 30, 2016, and would require additional sampling of the creek to verify. A sample collected from Morning Glory Arch Spring (sample 19, table 4) on November 19, 2015, a south-side tributary to Negro Bill Canyon, located within about $1 \mathrm{mi}$ of its mouth, is clearly GCGA water. This indicates that, whereas the water from the spring is part of the GCGA, the bulk of the groundwater that makes up the base flow to the creek in Negro Bill Canyon is not. Therefore, a groundwater divide likely exists, possibly along or south of the watershed upstream from Morning Glory Arch Spring. South of this divide, the Glen Canyon Group rocks are hydraulically connected to the primary GCGA that receives its recharge from high in the La Sal Mountains, whereas north of this divide, the Glen Canyon Group rocks are likely recharged from a lower-altitude source. 
Samples of water collected from Glen Canyon Group rocks in selected areas provide evidence that local recharge is not a significant contributor to the primary GCGA. Stableisotope compositions of vadose-zone pore-water samples (table 3), extracted from sandstone cores collected from boreholes drilled along the Sand Flats Road, are included in this analysis for comparison to groundwater sampled elsewhere in the study area (fig. 9). The vadose-zone samples exhibit a mixture of meteoric and evaporated isotopic signatures that are significantly heavier $\left(\delta^{18} \mathrm{O}\right.$ of -12.9 to $-9.7 \%$ ) than any groundwater samples from the GCGA, the VFA, or the LVFA. Their range of isotopic values indicates that their source is local precipitation, and the evaporative signature above the water table is consistent with lowinfiltration rates. Additionally, two samples were collected from Ice Box Canyon (table 7), a low-flow perennial stream flowing from a small (less than 1-mi-long) drainage in Glen Canyon Group rocks adjacent to the Colorado River and isolated from the larger GCGA. These samples, collected 6 months apart, are the isotopically heaviest samples encountered (fig. 9), indicating that the source of water to this stream is also local (low-altitude) precipitation. The difference in stable-isotope composition between the vadose zone and Ice Box Canyon samples, compared to samples from the larger GCGA, indicate that precipitation over the large Glen Canyon Group outcrop extending from the La Sal Mountains to the Colorado River is not a significant contributor of recharge to the primary GCGA.

Samples of water from one location on Pack Creek and two locations on Mill Creek were collected over approximately a 1 -year period to observe the isotopic compositions of the streams during base flow and runoff periods. These data are plotted with time and compared to the range of isotopic values observed in GCGA and all VFA and LVFA groundwaters (fig. 10). This was primarily done to evaluate whether stream loss from either creek might provide significant groundwater recharge to any part of the study area. It is clear from figure 10 that the isotopic signature of the stream water varies seasonally and becomes isotopically heavier (less negative) during periods of high stream-flow (associated with snow-melt) runoff. The isotopically lighter (more negative) samples collected during base flow likely indicate groundwater draining into the stream that was recharged at higher altitudes than the average altitude of the composite snowpack during peak melt. It is also apparent that none of the stable-isotope ratios of streamflow samples intersect the region of the isotopically lighter stable-isotope ratios of GCGA samples at any point during the year, providing strong evidence that GCGA groundwater originates as recharge from distinctly higher altitudes in the watershed than even the groundwater that provides base flow to these streams. The range of isotopic values seen in the streams over two cycles of peak flow and base flow clearly intersects the values observed in VFA groundwater, indicating that losing portions of either of these streams could provide recharge to the VFA.

\section{Dissolved Noble Gases}

Dissolved noble-gas concentrations and NGTs are presented for 18 sample sites in table 8 . The range of possible NGT values calculated for each of the sites is shown on figure 11, in which the left and right points for each sample represent $\mathrm{NGT}_{\min }$ and $\mathrm{NGT}_{\max }$, respectively. In this study, the complete set of estimated CE model parameters and fit $\left(\mathrm{A}_{\mathrm{e}}, \mathrm{F}\right.$, and sum of $\chi^{2}$ ) are presented only for the $\mathrm{H}_{\min }-\mathrm{NGT}_{\max }$ solution pair for each sample; the parameters $\left(\mathrm{A}_{\mathrm{e}}\right.$ and $\left.\mathrm{F}\right)$ and measure of model fit $\left(\chi^{2}\right)$ are similar for the remaining H-NGT pairs for each sample. In addition, water-table temperature data from mountain altitudes was measured at only one spring. This is insufficient to provide detailed constraints on modeled $\mathrm{NGT}_{\max }$ and $\mathrm{NGT}_{\min }$ values. Therefore, average NGT ( $\mathrm{NGT}_{\text {avg }}$ ) was simply calculated as the NGT value derived from the average altitude between the sample altitude and 9,842 ft.

Because NGTs represent estimates of recharge temperature (the water-table temperature at the location of recharge), they are compared to valley water-table temperatures to identify areas where groundwater consists of mountain rather than valley recharge. Domenico and Schwartz (1998) noted that shallow water-table temperatures (and thus, recharge temperatures, $T_{\mathrm{r}}$ ) are generally close to, but slightly warmer (about 1 to $2{ }^{\circ} \mathrm{C}$ ) than, the mean annual air temperature at the land surface for typical water-table depths of less than $65 \mathrm{ft}$. Because air temperatures and, thus, watertable temperatures decrease with increasing altitude, modern (or Holocene) mountain recharge should have $\mathrm{T}_{\mathrm{r}}$ values that are cooler than the temperature of the water table in adjacent valleys. Groundwater temperatures range from 12.6 to $19.3^{\circ} \mathrm{C}$ and average $15.9^{\circ} \mathrm{C}$ from 25 valley wells with water depths less than $300 \mathrm{ft}$ (samples U1-U27, table 6). These temperatures verify that water-table temperatures on average are about $2{ }^{\circ} \mathrm{C}$ warmer than mean annual air temperatures at Moab of $13.8^{\circ} \mathrm{C}$ (U.S. climate data, accessed August 31, 2017, at http://www.usclimatedata.com/climate/moab/utah/ united-states/usut0165). The discharge temperature of $9.0^{\circ} \mathrm{C}$ at one shallow mountain spring (sample 14), at an altitude of $7,909 \mathrm{ft}$, illustrates that mountain water-table temperatures are significantly cooler.

Values of $\mathrm{NGT}_{\text {min }}$ and $\mathrm{NGT}_{\max }$ for the study area range from 1.9 to $13.0^{\circ} \mathrm{C}$ and from 3.6 to $19.0^{\circ} \mathrm{C}$, respectively (fig. 11 and table 8). $\mathrm{NGT}_{\text {avg }}$ were cooler than valley watertable temperatures for 14 of the 18 samples $(1,2,3,5,6,8,10$, $11,12,13,14,15,16$, and 17), and within the range of valley recharge for 4 of the samples $\left(4,7,9\right.$, and 18; fig. 11). NGT ${ }_{\text {max }}$ also were cooler than valley water-table temperatures for 12 of the 14 samples mentioned above (all but samples 2 and 3), indicating that most groundwater recharge occurs either in the mountains or at a higher altitude in the valley where the water table is notably cooler. 

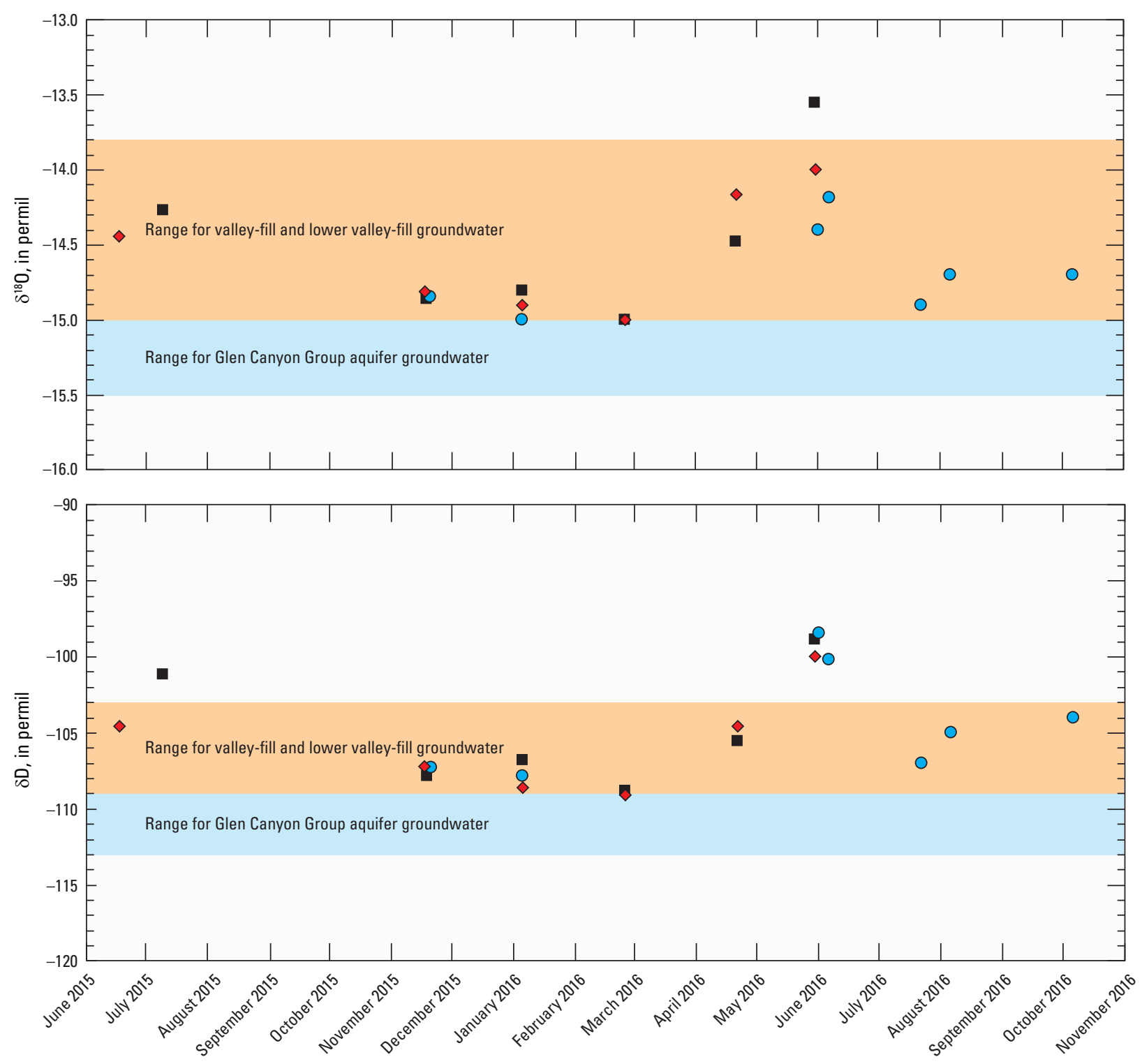

EXPLANATION

O Mill Creek at Sheley Tunnel, near Moab, Utah

$\diamond$ Mill Creek near Moab, at Powerhouse Dam

- Pack Creek at Pack Creek Road Bridge

Figure 10. Stable-isotope values of surface-water samples collected in Mill Creek and Pack Creek compared to the range of values observed in groundwater samples from the Glen Canyon Group aquifer and valley-fill aquifer in the Spanish Valley study area, Utah.

A spring at 5,900 $\mathrm{ft}$ adjacent to the upper part of the Sand Flats Road (sample 9) had a measured discharge temperature of $15.0^{\circ} \mathrm{C}$, and an $\mathrm{NGT}_{\min }-\mathrm{NGT}_{\max }$ range of 12.1 to $14.3^{\circ} \mathrm{C}$. This spring emanates from a topographically isolated highaltitude outcrop of the Glen Canyon Group above the altitude of the road, constraining its recharge location to within about $2 \mathrm{mi}$ and below 7,500 ft. The water-table temperature measured in a shallow alluvial well at $6,100 \mathrm{ft}$ in the PCD (sample 16) was $11.5^{\circ} \mathrm{C}$ where the full range of NGTs for the same well was 6.5 to $8.3^{\circ} \mathrm{C}$, indicating that groundwater recharge occurs to alluvium at high altitudes along Pack
Creek. The temperature of discharge measured at a spring just above 7,900 $\mathrm{ft}$ in the La Sal Mountains (sample 14) was $9.0^{\circ} \mathrm{C}$, and the $\mathrm{NGT}_{\text {min }}-\mathrm{NGT}_{\text {max }}$ range of that spring was 7.9 to $8.8^{\circ} \mathrm{C}$, indicating that it was recharged not far above its outlet and that NGTs less than $9.0^{\circ} \mathrm{C}$ likely occur above about 8,000 $\mathrm{ft}$ in the La Sal Mountains. This small group of measured temperatures and modeled NGTs from springs above the valley floor provide important examples of, and plausible constraints on, the water-table temperature relation to altitude within the study area. 
[See appendix table 1-1 for additional information. Sample method: CT, copper tube; DS, diffusion sampler. Abbreviations: ID, identification; USGS, U.S. Geological Survey; ${ }^{\circ} \mathrm{C}$, degrees Celsius; $\mathrm{mm} \mathrm{Hg}$, millimeters of mercury; $\mathrm{ccSTP} / \mathrm{g}$, cubic centimeters at standard temperature and pressure per gram of water; $\mathrm{H}_{\text {min }}$, minimum recharge altitude, which is the altitude at which the sample was collected; $\mathrm{ft}$, feet; $\mathrm{NGT}_{\text {mox }}$, maximum noble-gas temperature calculated using $\mathrm{H}_{\mathrm{m}} ; \mathrm{A}$, dimensionless ratio of the total volume of trapped (moist) air at the pressure and temperature of the free atmosphere to the volume of water; F, fractionation factor for partial dissolution of trapped air bubbles; $\Sigma \chi^{2}$, sum of error-weighted misfit for each of the noble gases; $\mathrm{H}_{\text {avg }}$, average recharge altitude; NGT $\mathrm{avg}_{\text {, }}$ average noble-gas recharge temperature; $\mathrm{H}_{\max }$, maximum recharge altitude; $\mathrm{NGT}_{\min }$, minimum noble-gas recharge temperature]

\begin{tabular}{|c|c|c|c|c|c|c|c|c|c|c|c|c|c|c|c|c|c|}
\hline \multirow[b]{2}{*}{$\begin{array}{c}\text { Sample } \\
\text { ID }\end{array}$} & \multirow[b]{2}{*}{$\begin{array}{c}\text { USGS } \\
\text { site number }\end{array}$} & \multirow[b]{2}{*}{$\begin{array}{l}\text { Sample } \\
\text { method }\end{array}$} & \multirow{2}{*}{$\begin{array}{c}\text { Water } \\
\text { temperature } \\
\left({ }^{\circ} \mathrm{C}\right)\end{array}$} & \multirow{2}{*}{$\begin{array}{l}\text { Dissolved } \\
\text { gas } \\
\text { pressure } \\
(\mathrm{mm} \mathrm{Hg})\end{array}$} & \multicolumn{4}{|c|}{ Dissolved noble-gas concentrations } & \multicolumn{9}{|c|}{ Modeled recharge parameters } \\
\hline & & & & & $\begin{array}{c}\text { Neon } \\
\text { (ccSTP/g) }\end{array}$ & $\begin{array}{c}\text { Argon } \\
\text { (ccSTP/g) }\end{array}$ & $\begin{array}{l}\text { Krypton } \\
\text { (ccSTP/g) }\end{array}$ & $\begin{array}{c}\text { Xenon } \\
\text { (ccSTP/g) }\end{array}$ & $\begin{array}{l}\mathbf{H}_{\min } \\
\text { (ft) }\end{array}$ & $\begin{array}{l}\text { NGT }_{\text {max }} \\
\left({ }^{\circ} \mathrm{C}\right)\end{array}$ & $\begin{array}{c}A_{e} \\
\text { (unitless) }\end{array}$ & $\begin{array}{c}\mathbf{F} \\
\text { (unitless) }\end{array}$ & $\Sigma \chi^{2}$ & $\begin{array}{l}H_{\text {avg }} \\
(\mathrm{ft})\end{array}$ & $\begin{array}{c}\mathrm{NGT}_{\text {avg }} \\
\left({ }^{\circ} \mathrm{C}\right)^{-}\end{array}$ & $\begin{array}{c}\mathbf{H}_{\max } \\
(\mathrm{ft})\end{array}$ & $\begin{array}{l}\mathrm{NGT}_{\text {min }} \\
\left({ }^{\circ} \mathrm{C}\right)\end{array}$ \\
\hline 1 & 383545109335701 & $\mathrm{CT}$ & 17.6 & 665 & $1.59 \times 10^{-7}$ & $3.18 \times 10^{-4}$ & $7.34 \times 10^{-8}$ & $1.02 \times 10^{-8}$ & 4,057 & 11.9 & 0.0003 & ${ }^{1} 3.00$ & 0.88 & 6,950 & 8.9 & 9,842 & 7.6 \\
\hline 2 & 383238109302501 & $\mathrm{CT}$ & 14.9 & - & $2.25 \times 10^{-7}$ & $3.72 \times 10^{-4}$ & $8.18 \times 10^{-8}$ & $1.11 \times 10^{-8}$ & 4,360 & 12.7 & 0.0379 & 0.68 & 0.00 & 7,101 & 10.2 & 9,842 & 7.6 \\
\hline 3 & 383148109292201 & DS & 15.0 & 699 & $2.03 \times 10^{-7}$ & $3.33 \times 10^{-4}$ & $7.07 \times 10^{-8}$ & $1.02 \times 10^{-8}$ & 4,484 & 14.5 & 0.0235 & 0.73 & 0.68 & 7,163 & 12.0 & 9,842 & 9.4 \\
\hline 4 & 383224109284701 & $\mathrm{CT}$ & 15.5 & 692 & $1.69 \times 10^{-7}$ & $2.86 \times 10^{-4}$ & $8.79 \times 10^{-8}$ & $8.71 \times 10^{-9}$ & 4,670 & 19.0 & 0.2461 & 0.92 & 0.00 & 7,256 & 19.1 & 9,842 & 13.0 \\
\hline 5 & 383224109294401 & DS & 15.2 & 667 & $1.76 \times 10^{-7}$ & $3.34 \times 10^{-4}$ & $7.14 \times 10^{-8}$ & $1.07 \times 10^{-8}$ & 4,470 & 11.2 & 0.1117 & 0.95 & 3.62 & 7,156 & 9.7 & 9,842 & 8.1 \\
\hline 5 (replicate) & 383224109294401 & DS & 15.2 & 667 & $1.72 \times 10^{-7}$ & $3.19 \times 10^{-4}$ & $7.14 \times 10^{-8}$ & $1.04 \times 10^{-8}$ & 4,470 & 12.3 & 0.0991 & 0.97 & 0.52 & 7,156 & 10.4 & 9,842 & 8.0 \\
\hline 6 & 383149109284601 & DS & 15.4 & 655 & $1.82 \times 10^{-7}$ & $3.14 \times 10^{-4}$ & $7.21 \times 10^{-8}$ & $1.08 \times 10^{-8}$ & 4,571 & 12.5 & 0.0008 & 0.00 & 1.40 & 7,207 & 9.1 & 9,842 & 5.7 \\
\hline 7 & 383312109322701 & DS & 15.8 & 651 & $1.64 \times 10^{-7}$ & $2.93 \times 10^{-4}$ & $6.57 \times 10^{-8}$ & $9.46 \times 10^{-9}$ & 4,209 & 15.3 & 0.1110 & 1.00 & 0.19 & 7,026 & 12.7 & 9,842 & 10.0 \\
\hline 8 & 383312109263501 & DS & 12.6 & 636 & $1.76 \times 10^{-7}$ & $3.32 \times 10^{-4}$ & $7.69 \times 10^{-8}$ & $1.08 \times 10^{-8}$ & 4,907 & 10.7 & 0.1339 & 0.94 & 0.16 & 7,375 & 9.6 & 9,842 & 9.7 \\
\hline 9 & 383457109245401 & DS & 15.0 & 600 & $1.68 \times 10^{-7}$ & $3.03 \times 10^{-4}$ & $6.28 \times 10^{-8}$ & $8.85 \times 10^{-9}$ & 5,897 & 14.3 & 0.0870 & 0.91 & 3.64 & 7,870 & 13.2 & 9,842 & 12.1 \\
\hline 10 & 383043109282401 & $\mathrm{CT}$ & 15.7 & 745 & $2.23 \times 10^{-7}$ & $3.58 \times 10^{-4}$ & $7.90 \times 10^{-8}$ & $1.16 \times 10^{-8}$ & 4,647 & 9.4 & 0.0047 & 0.30 & 0.00 & 7,245 & 7.0 & 9,842 & 4.7 \\
\hline 11 & 383113109281201 & $\mathrm{CT}$ & 16.1 & 688 & $1.78 \times 10^{-7}$ & $3.09 \times 10^{-4}$ & $7.35 \times 10^{-8}$ & $1.09 \times 10^{-8}$ & 4,673 & 11.8 & 0.0006 & 0.00 & 1.37 & 7,258 & 8.7 & 9,842 & 5.7 \\
\hline 12 & 383340109314301 & $\mathrm{CT}$ & 16.5 & 791 & $2.15 \times 10^{-7}$ & $3.51 \times 10^{-4}$ & $7.81 \times 10^{-8}$ & $1.08 \times 10^{-8}$ & 4,155 & 12.2 & 0.0142 & 0.64 & 0.00 & 6,999 & 9.6 & 9,842 & 7.0 \\
\hline 13 & 382849109255901 & $\mathrm{CT}$ & 17.3 & 710 & $1.84 \times 10^{-7}$ & $3.15 \times 10^{-4}$ & $7.28 \times 10^{-8}$ & $1.03 \times 10^{-8}$ & 5,022 & 11.9 & 0.0010 & 0.00 & 0.02 & 7,432 & 9.4 & 9,842 & 7.2 \\
\hline 14 & 383026109200301 & DS & 9.0 & 540 & $1.69 \times 10^{-7}$ & $3.28 \times 10^{-4}$ & $7.52 \times 10^{-8}$ & $1.03 \times 10^{-8}$ & 7,909 & 8.8 & 0.1297 & 0.88 & 1.91 & 8,876 & 8.4 & 9,842 & 7.9 \\
\hline 15 & 383308109224601 & $\mathrm{CT}$ & 15.0 & 725 & $2.31 \times 10^{-7}$ & $3.99 \times 10^{-4}$ & $8.76 \times 10^{-8}$ & $1.31 \times 10^{-8}$ & 6,981 & 3.6 & 0.0201 & 0.56 & 0.00 & 8,412 & 2.8 & 9,842 & 1.9 \\
\hline 16 & 382621109214001 & $\mathrm{CT}$ & 11.5 & 631 & $1.63 \times 10^{-7}$ & $3.27 \times 10^{-4}$ & $7.90 \times 10^{-8}$ & $1.09 \times 10^{-8}$ & 6,112 & 8.3 & 0.1387 & 0.99 & 0.61 & 7,977 & 7.4 & 9,842 & 6.5 \\
\hline 17 & 382929109272101 & $\mathrm{CT}$ & 17.0 & 681 & $1.73 \times 10^{-7}$ & $3.23 \times 10^{-4}$ & $7.59 \times 10^{-8}$ & $1.06 \times 10^{-8}$ & 4,826 & 11.6 & 0.1347 & 0.96 & 0.03 & 7,334 & 10.7 & 9,842 & 11.0 \\
\hline 18 & 383024109283801 & CT & 17.5 & 753 & $1.91 \times 10^{-7}$ & $3.46 \times 10^{-4}$ & $7.85 \times 10^{-8}$ & $1.11 \times 10^{-8}$ & 4,680 & 13.6 & 0.4590 & 0.85 & 0.00 & 7,261 & 13.7 & 9,842 & 6.6 \\
\hline
\end{tabular}

${ }^{1}$ Value of $\mathrm{F}$ greater than 1 indicates that this sample may have undergone degassing. However, comparison to the unfractionated excess-air (UA) model results shows no significant difference in calculated NGT values. 


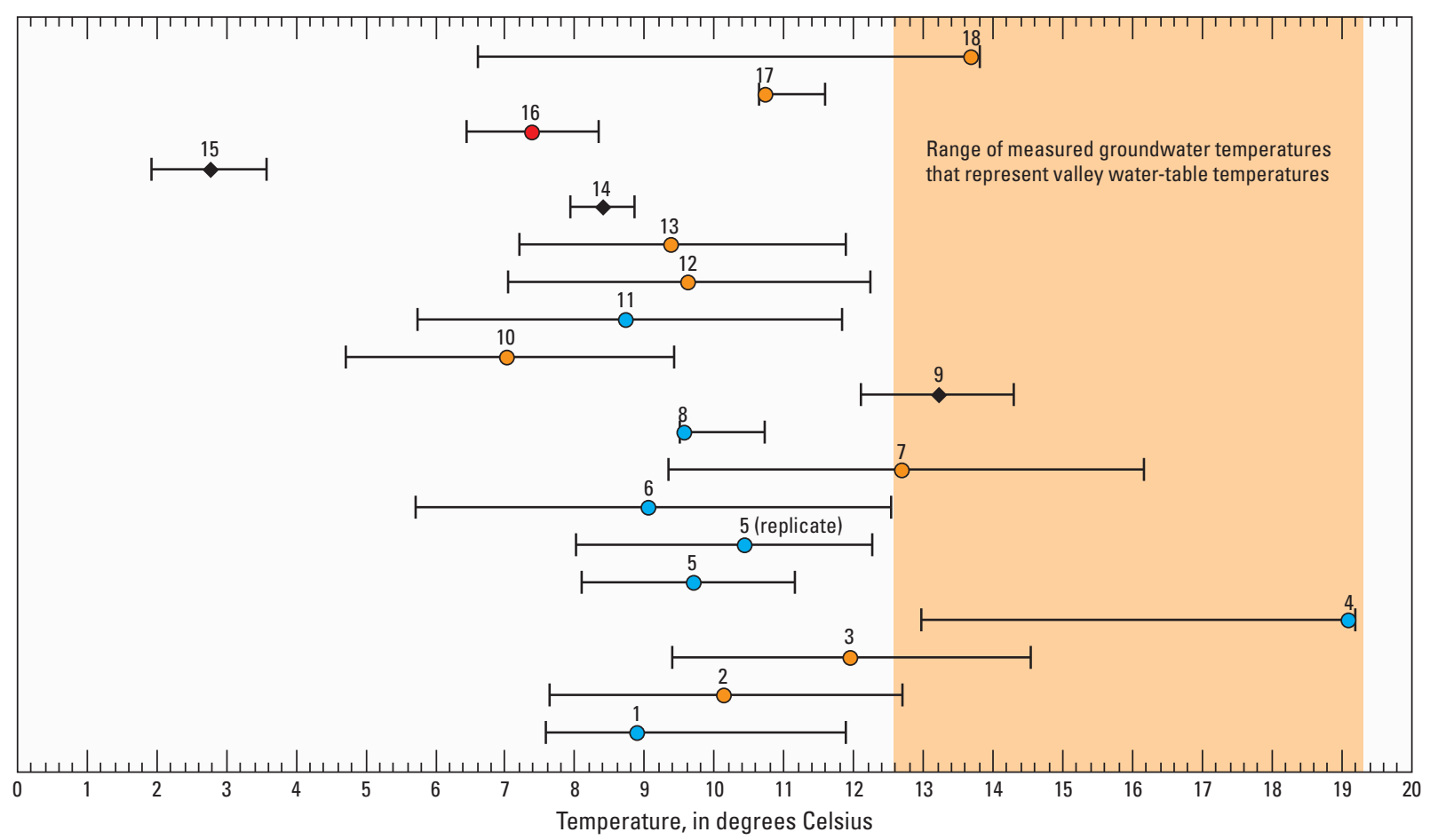

EXPLANATION

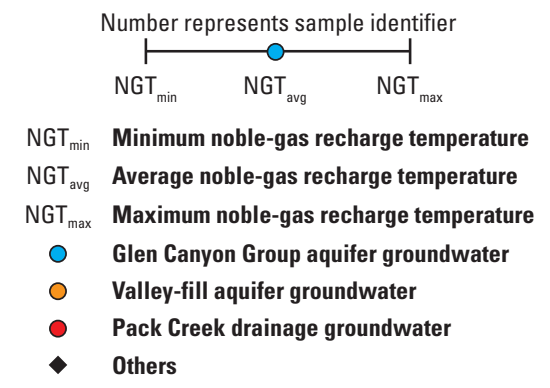

Figure 11. Noble-gas recharge temperatures for groundwater compared to valley water-table temperatures in the Spanish Valley study area, Utah.

$\mathrm{NGT}_{\text {avg }}$, the mid-point for each sample displayed on figure 11, is calculated by assuming that the recharge altitude $\left(\mathrm{H}_{\mathrm{r}}\right)$ is equal to the mean altitude between the sample site and 9,842 ft, assumed to be the highest altitude that recharge occurs within the study area. The $\mathrm{NGT}_{\text {avg }}$ values were less than measured sample water temperatures for all but one of the samples collected (sample 4, table 8), which was expected assuming recharge occurred at a higher altitude than the altitude of sample collection. The $\mathrm{NGT}_{\max }$ and $\mathrm{NGT}_{\text {arg }}$ values for sample 4 were higher than measured water temperature for that sample, indicating that the noble gas sample was compromised during collection and should be disregarded as an outlier.

$\mathrm{NGT}_{\text {arg }}$ of the seven GCGA waters (excluding sample 4) ranged from 8.7 to $10.4{ }^{\circ} \mathrm{C}$, with an average of $9.4^{\circ} \mathrm{C}$. NGT of the eight VFA waters ranged from 7.0 to $13.7^{\circ} \mathrm{C}$, with an average of $10.7^{\circ} \mathrm{C}$. Despite the overlap in the range of values between GCGA and VFA groundwater, the GCGA waters generally had cooler NGTs, signifying that groundwater in
Moab-Spanish Valley likely contains integrated mixtures of water recharged from separate source areas with different altitudes. The only sample representing PCD source water was sample 16, with an $\mathrm{NGT}_{\text {avg }}$ value of $7.4^{\circ} \mathrm{C}$, confirming that high-altitude recharge occurs in the PCD.

\section{Tritium and Helium}

Groundwater ${ }^{3} \mathrm{H}$ concentrations ranged from below detection (about $0.1 \mathrm{TU}$ ) to $5.1 \mathrm{TU}$ and clearly identified "modern" water ( ${ }^{3} \mathrm{H}$ greater than $\left.1 \mathrm{TU}\right)$ at 28 of the 49 sample sites within the study area (tables 9 and 10). ${ }^{4} \mathrm{He}_{\text {terr }}$ concentrations ranged from below detection to $9.37 \times 10^{-6} \mathrm{ccSTP} / \mathrm{g}$, and $\mathrm{R} / \mathrm{R}_{\mathrm{a}}$ values ranged from 0.07 to 2.05. The high end of the ${ }^{4} \mathrm{He}_{\text {terr }}$ concentrations and low end of the $\mathrm{R} / \mathrm{R}_{\mathrm{a}}$ values clearly indicate that some of the samples contained water that is older than water that can be dated using the ${ }^{3} \mathrm{H} /{ }^{3} \mathrm{He}_{\text {trit }}$ method. 
Table 9. Stable- and radio-isotope data and industrial gas concentrations used to estimate ages of groundwater sampled in the Spanish Valley study area, Utah.

[See appendix table 1-1 for additional information. Pre-modern, groundwater that recharged prior to the mid-1950s; Modern mixture, sample that contains a mixture of pre-modern and modern groundwater. Abbreviations: ID, identification; USGS, U.S. Geological Survey; TU, tritium units; ccSTP/g, cubic centimeters per gram of water at standard temperature and pressure; ${ }^{3} \mathrm{H}$, tritium; ${ }^{3} \mathrm{He}$, tritiogenic helium-3; BP, before present; $\mathrm{SF}$, sulfur hexafluoride; pptv, parts per trillion, volume; CFC, chlorofluorocarbon; pmC, percent modern carbon; $\delta^{13} \mathrm{C}$, ratio of ratio of carbon-13 to carbon-12 in sample to ratio of carbon-13 to carbon-12 in reference; permil, parts per thousand; A, initial carbon-14 of groundwater total dissolved inorganic carbon; <, less than; \pm , plus or minus; - - no data]

\begin{tabular}{|c|c|c|c|c|c|c|c|c|c|}
\hline $\begin{array}{l}\text { Sample } \\
\text { ID }\end{array}$ & $\begin{array}{c}\text { USGS } \\
\text { site number }\end{array}$ & $\begin{array}{l}\text { Tritium and } \\
\text { precision } \\
\text { (TU) }\end{array}$ & $\begin{array}{c}\text { 'R/Ra } \\
\text { (unitless) }\end{array}$ & $\begin{array}{l}\text { Measured } \\
\text { helium-4 } \\
\text { (ccSTP/g) }\end{array}$ & $\begin{array}{l}{ }^{2} \text { Terrigenic } \\
\text { helium-4 } \\
\text { (ccSTP/g) }\end{array}$ & $\begin{array}{l}\text { Tritiogenic } \\
\text { helium-3 } \\
\text { (TU) }\end{array}$ & $\begin{array}{c}\text { Apparent }{ }^{3} \mathrm{H} /{ }^{3} \mathrm{He} \\
\text { age (years } \mathrm{BP} \text { ) or } \\
\text { categorical age }\end{array}$ & $\begin{array}{c}\mathrm{SF}_{6} \\
\text { (pptv) }\end{array}$ & $\begin{array}{l}\text { Apparent } \\
\text { SF }_{6} \text { age } \\
\text { (years BP) }\end{array}$ \\
\hline 1 & 383545109335701 & $0.33 \pm 0.09$ & 0.64 & $6.26 \times 10^{-8}$ & $2.40 \times 10^{-8}$ & 1.0 & Pre-modern & 3.9 & 18.9 \\
\hline 2 & 383238109302501 & $2.1 \pm 0.16$ & 1.14 & $6.47 \times 10^{-8}$ & $9.66 \times 10^{-9}$ & 10.6 & 34.1 & 0.3 & 43.4 \\
\hline 3 & 383148109292201 & $3.9 \pm 0.27$ & 1.35 & $5.92 \times 10^{-8}$ & $1.07 \times 10^{-8}$ & 17.3 & Modern mixture & 0.5 & 38.9 \\
\hline 4 & 383224109284701 & $0.75 \pm 0.10$ & 0.86 & $5.26 \times 10^{-8}$ & $1.27 \times 10^{-8}$ & 3.0 & Modern mixture & 0.1 & 60.4 \\
\hline 5 (replicate) & 383224109294401 & $0.17 \pm 0.06$ & 0.82 & $5.55 \times 10^{-8}$ & $2.38 \times 10^{-8}$ & 7.4 & Pre-modern & 0.1 & 51.4 \\
\hline 6 & 383149109284601 & $0.38 \pm 0.25$ & 0.88 & $4.97 \times 10^{-8}$ & $7.10 \times 10^{-9}$ & 0.6 & Pre-modern & 3.2 & 21.9 \\
\hline 7 & 383312109322701 & $0.33 \pm 0.06$ & 1.00 & $4.09 \times 10^{-8}$ & $2.10 \times 10^{-9}$ & 1.1 & Pre-modern & - & - \\
\hline 8 & 383312109263501 & $2.3 \pm 0.17$ & 1.05 & $4.023 \times 10^{-8}$ & $-4.68 \times 10^{-10}$ & 0.8 & 6.3 & 0.2 & 47.4 \\
\hline 12 & 383340109314301 & $1.8 \pm 0.15$ & 1.00 & $5.37 \times 10^{-8}$ & $3.26 \times 10^{-9}$ & 2.2 & 13.2 & 3.6 & 19.9 \\
\hline 13 & 382849109255901 & $5.1 \pm 0.37$ & 1.17 & $4.33 \times 10^{-8}$ & $-1.02 \times 10^{-11}$ & 4.4 & 11.1 & 1.4 & 31.4 \\
\hline 14 & 383026109200301 & $2.7 \pm 0.21$ & 1.04 & $3.70 \times 10^{-8}$ & $-2.44 \times 10^{-9}$ & -0.4 & $<1$ & 0.4 & 40.7 \\
\hline 15 & 383308109224601 & $0.05 \pm 0.04$ & 0.55 & $1.16 \times 10^{-7}$ & $6.03 \times 10^{-8}$ & 4.5 & Pre-modern & 0.2 & 46.5 \\
\hline 16 & 382621109214001 & $2.7 \pm 0.19$ & 0.96 & $4.14 \times 10^{-8}$ & $3.77 \times 10^{-9}$ & 1.5 & 8.7 & 0.3 & 42.2 \\
\hline 17 & 382929109272101 & $3.6 \pm 0.46$ & 1.22 & $4.34 \times 10^{-8}$ & $3.43 \times 10^{-9}$ & 7.4 & 20.0 & 0.1 & 50.0 \\
\hline 18 & 383024109283801 & $0.29 \pm 0.06$ & 0.83 & $6.46 \times 10^{-8}$ & $1.97 \times 10^{-8}$ & 4.9 & Pre-modern & - & - \\
\hline 19 & 383537109303001 & $0.53 \pm 0.04$ & - & - & - & - & - & - & - \\
\hline
\end{tabular}


Table 9. Stable- and radio-isotope data and industrial gas concentrations used to estimate ages of groundwater sampled in the Spanish Valley study area, Utah.-Continued

[See appendix table 1-1 for additional information. Pre-modern, groundwater that recharged prior to the mid-1950s; Modern mixture, sample that contains a mixture of pre-modern and modern groundwater. Abbreviations: ID, identification; USGS, U.S. Geological Survey; TU, tritium units; ccSTP/g, cubic centimeters per gram of water at standard temperature and pressure; ${ }^{3} \mathrm{H}$, tritium; ${ }^{3} \mathrm{He}$, tritiogenic helium-3; BP, before present; $\mathrm{SF}_{6}$, sulfur hexafluoride; pptv, parts per trillion, volume; $\mathrm{CFC}$, chlorofluorocarbon; pmC, percent modern carbon; $\delta^{13} \mathrm{C}$, ratio of ratio of carbon- 13 to carbon-12 in sample to ratio of carbon-13 to carbon-12 in reference; permil, parts per thousand; A, initial carbon-14 of groundwater total dissolved inorganic carbon; <, less than; \pm , plus or minus; - - no data]

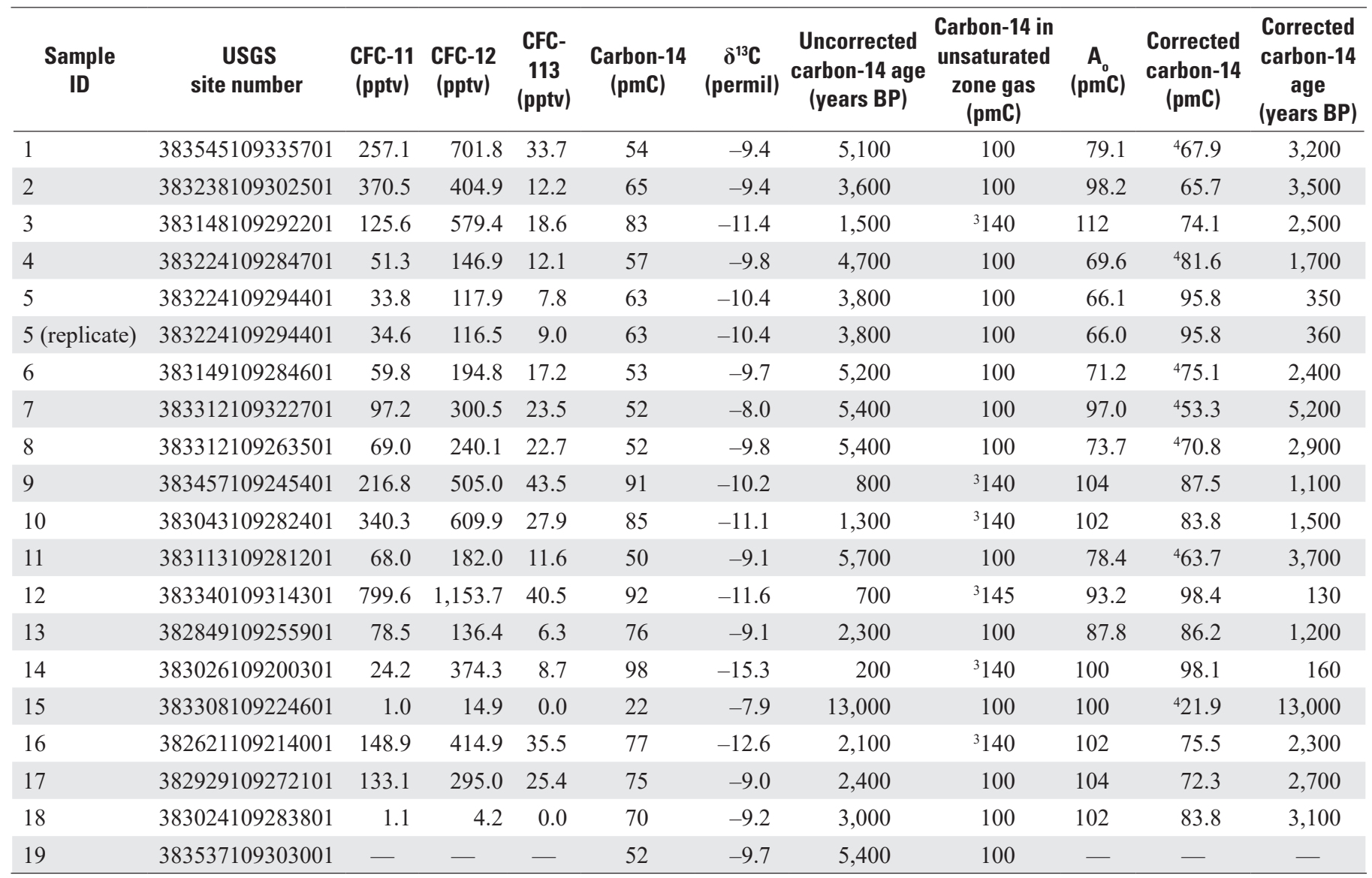

${ }^{1} \mathrm{R}$ is the ${ }^{3} \mathrm{He} /{ }^{4} \mathrm{He}$ ratio of the sample, and $\mathrm{Ra}$ is the ${ }^{3} \mathrm{He} /{ }^{4} \mathrm{He}$ ratio of air $\left(1.384 \times 10^{-6}\right)$.

${ }_{2}^{2}$ Interpreted value derived using the closed-equilibrium dissolved-gas model (Aeschbach-Hertig and others, 2000; Kipfer and others, 2002).

${ }^{3}$ Unsaturated zone gas was changed to greater than $100 \mathrm{pmC}$, representing the presence of elevated carbon-14 activities associated with above-ground nuclear testing; geochemical models using $100 \mathrm{pmC}$ unsaturated zone gas activities for these samples produced negative ages.

${ }^{4}$ Reasonably well-defined carbon-14 "single-sample" analytical correction. Falls below "zero-age" line as defined by Han and others (2012).

Tritium and tritiogenic helium samples are categorized as containing (1) mostly modern water, (2) a mixture of modern and pre-modern water, or (3) all pre-modern water (fig. 12). Waters were characterized as mostly modern if they had ${ }^{3} \mathrm{H}$ concentrations greater than $1 \mathrm{TU}, \mathrm{R} / \mathrm{R}_{\mathrm{a}}$ values of greater than 0.95 , and low ${ }^{4} \mathrm{He}_{\text {terr }}$ concentrations (generally less than $1.00 \times 10^{-8} \mathrm{ccSTP} / \mathrm{g}$ ), and as pre-modern if they had ${ }^{3} \mathrm{H}$ concentrations less than $0.4 \mathrm{TU}$. As expected, most of the premodern waters had $\mathrm{R} / \mathrm{R}_{\mathrm{a}}$ values of less than 0.95 , and ${ }^{4} \mathrm{He}_{\text {terr }}$ concentrations greater than $1.00 \times 10^{-8} \mathrm{ccSTP} / \mathrm{g}$. Waters were characterized as a mixture of modern and pre-modern if any of the following were true: (1) they had ${ }^{3} \mathrm{H}$ concentrations greater than $0.4 \mathrm{TU}$ and less than $1.0 \mathrm{TU}$, and $\mathrm{R} / \mathrm{R}_{\mathrm{a}}$ values of less than 0.95 or, (2) they had ${ }^{3} \mathrm{H}$ concentrations greater than $1 \mathrm{TU}$, and notably elevated concentrations of ${ }^{4} \mathrm{He}_{\text {terr }}$ (generally greater than $1.00 \times 10^{-8} \mathrm{ccSTP} / \mathrm{g}$ ), regardless of the $\mathrm{R} / \mathrm{R}_{\mathrm{a}}$ value. It is difficult to assign an absolute limit on ${ }^{4} \mathrm{He}_{\text {terr }}$ concentrations for this characterization because it is determined based on values that are not precisely known (for example, the excess air content of the water sample and the accumulation rate of terrigenic helium). However, elevated ${ }^{4} \mathrm{He}_{\text {terr }}$ indicates water that has been in contact with aquifer materials for significantly longer than is required for ${ }^{3} \mathrm{H}$ to decay to below detection limits, thus indicating the presence of a pre-modern fraction. 
Table 10. Stable- and radio-isotope data and industrial gas concentrations measured by Nelson (2017) used to estimate ages of groundwater sampled in the Spanish Valley study area, Utah.

[See appendix table 1-1 for additional information. Pre-modern, groundwater that recharged prior to the mid-1950s; Modern mixture, sample that contains a mixture of pre-modern and modern groundwater. Abbreviations: ID, identification; USGS, U.S. Geological Survey; TU, tritium units; ccSTP/g, cubic centimeters per gram of water at standard temperature and pressure; ${ }^{3} \mathrm{H}$, tritium; ${ }^{3} \mathrm{He}$, tritiogenic helium-3; BP, before present; $\mathrm{SF}$, sulfur hexafluoride; pptv, parts per trillion, volume; $\mathrm{CFC}$, chlorofluorocarbon; pmC, percent modern carbon; $\delta^{13} \mathrm{C}$, ratio of ratio of carbon-13 to carbon-12 in sample to ratio of carbon-13 to carbon-12 in reference; permil, parts per thousand; -, no data; \pm , plus or minus]

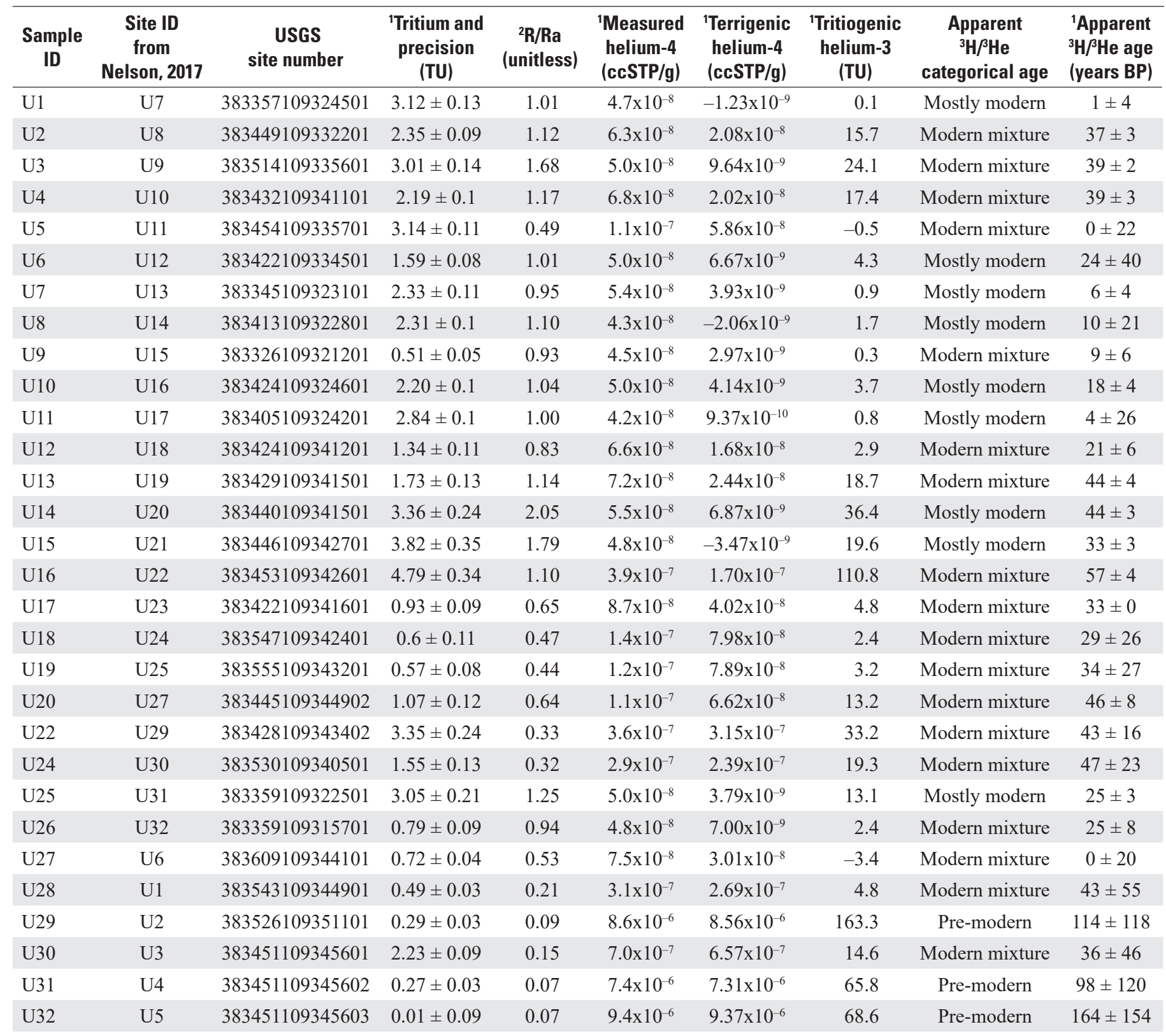


Table 10. Stable- and radio-isotope data and industrial gas concentrations measured by Nelson (2017) used to estimate ages of groundwater sampled in the Spanish Valley study area, Utah.-Continued

[See appendix table 1-1 for additional information. Pre-modern, groundwater that recharged prior to the mid-1950s; Modern mixture, sample that contains a mixture of pre-modern and modern groundwater. Abbreviations: ID, identification; USGS, U.S. Geological Survey; TU, tritium units; ccSTP/g, cubic centimeters per gram of water at standard temperature and pressure; ${ }^{3} \mathrm{H}$, tritium; ${ }^{3} \mathrm{He}$, tritiogenic helium-3; BP, before present; $\mathrm{SF}_{6}$, sulfur hexafluoride; pptv, parts per trillion, volume; CFC, chlorofluorocarbon; pmC, percent modern carbon; $\delta^{13} \mathrm{C}$, ratio of ratio of carbon-13 to carbon- 12 in sample to ratio of carbon-13 to carbon-12 in reference; permil, parts per thousand; -, no data; \pm , plus or minus]

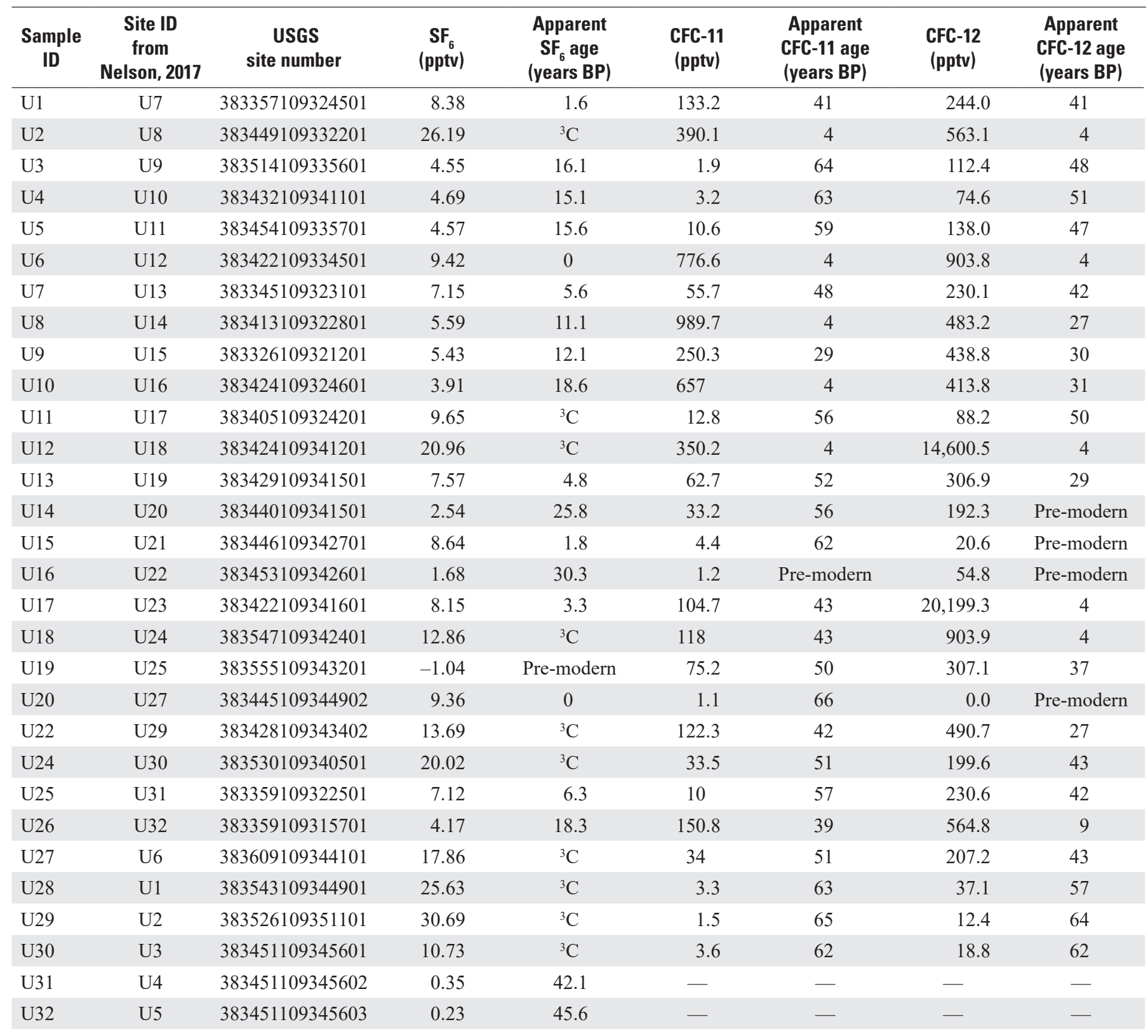


Table 10. Stable- and radio-isotope data and industrial gas concentrations measured by Nelson (2017) used to estimate ages of groundwater sampled in the Spanish Valley study area, Utah.-Continued

[See appendix table 1-1 for additional information. Pre-modern, groundwater that recharged prior to the mid-1950s; Modern mixture, sample that contains a mixture of pre-modern and modern groundwater. Abbreviations: ID, identification; USGS, U.S. Geological Survey; TU, tritium units; ccSTP/g, cubic centimeters per gram of water at standard temperature and pressure; ${ }^{3} \mathrm{H}$, tritium; ${ }^{3} \mathrm{He}$, tritiogenic helium-3; $\mathrm{BP}$, before present; $\mathrm{SF}_{6}$, sulfur hexafluoride; pptv, parts per trillion, volume; $\mathrm{CFC}$, chlorofluorocarbon; pmC, percent modern carbon; $\delta^{13} \mathrm{C}$, ratio of ratio of carbon-13 to carbon-12 in sample to ratio of carbon-13 to carbon-12 in reference; permil, parts per thousand; -, no data; \pm , plus or minus]

\begin{tabular}{|c|c|c|c|c|c|c|c|}
\hline $\begin{array}{l}\text { Sample } \\
\text { ID }\end{array}$ & $\begin{array}{c}\text { Site ID } \\
\text { from } \\
\text { Nelson, } 2017\end{array}$ & $\begin{array}{c}\text { USGS } \\
\text { site number }\end{array}$ & $\begin{array}{c}\text { CFC-113 } \\
\text { (pptv) }\end{array}$ & $\begin{array}{l}\text { Apparent } \\
\text { CFC-13 age } \\
\text { (years BP) }\end{array}$ & $\begin{array}{c}\text { Carbon-14 } \\
(\mathrm{pmC})\end{array}$ & $\begin{array}{c}\boldsymbol{\delta}^{13} \mathbf{C} \\
\text { (permil) }\end{array}$ & $\begin{array}{c}\text { Uncorrected } \\
\text { carbon-14 age } \\
\text { (years BP) }\end{array}$ \\
\hline U1 & $\mathrm{U} 7$ & 383357109324501 & 26.0 & 36 & - & - & - \\
\hline $\mathrm{U} 2$ & U8 & 383449109332201 & 13.9 & 41 & - & - & - \\
\hline U3 & U9 & 383514109335601 & 0.0 & 74 & - & - & - \\
\hline $\mathrm{U} 4$ & U10 & 383432109341101 & 0.0 & 74 & - & - & - \\
\hline U5 & U11 & 383454109335701 & 2.3 & 65 & 95 & -14.33 & 410 \\
\hline U6 & U12 & 383422109334501 & 35.7 & 34 & - & - & - \\
\hline U7 & U13 & 383345109323101 & 5.0 & 48 & - & - & - \\
\hline U8 & U14 & 383413109322801 & 30.4 & 35 & - & - & - \\
\hline U9 & U15 & 383326109321201 & 32.3 & 35 & - & - & - \\
\hline U10 & U16 & 383424109324601 & 31.7 & 35 & - & - & - \\
\hline U11 & U17 & 383405109324201 & 2.3 & 59 & - & - & - \\
\hline U12 & U18 & 383424109341201 & 32.2 & 35 & - & - & - \\
\hline U13 & U19 & 383429109341501 & 15.0 & 55 & - & - & - \\
\hline U14 & $\mathrm{U} 20$ & 383440109341501 & 9.5 & 56 & - & - & - \\
\hline U15 & $\mathrm{U} 21$ & 383446109342701 & 2.3 & 54 & - & - & - \\
\hline U16 & $\mathrm{U} 22$ & 383453109342601 & 2.0 & 58 & - & - & - \\
\hline U17 & $\mathrm{U} 23$ & 383422109341601 & 9.2 & 44 & - & - & - \\
\hline U18 & $\mathrm{U} 24$ & 383547109342401 & 72.1 & 32 & - & - & - \\
\hline U19 & $\mathrm{U} 25$ & 383555109343201 & 22.3 & 39 & - & - & - \\
\hline $\mathrm{U} 20$ & $\mathrm{U} 27$ & 383445109344902 & 1.4 & 61 & - & - & - \\
\hline $\mathrm{U} 22$ & U29 & 383428109343402 & 32.9 & 35 & - & - & - \\
\hline $\mathrm{U} 24$ & U30 & 383530109340501 & 7.4 & 46 & - & - & - \\
\hline $\mathrm{U} 25$ & U31 & 383359109322501 & 1.9 & 65 & - & - & - \\
\hline U26 & U32 & 383359109315701 & 40.8 & 33 & - & - & - \\
\hline U27 & U6 & 383609109344101 & 0.8 & 67 & 85 & -10.88 & 1,400 \\
\hline $\mathrm{U} 28$ & U1 & 383543109344901 & 0.6 & 68 & - & - & - \\
\hline U29 & $\mathrm{U} 2$ & 383526109351101 & 0.0 & 74 & - & - & - \\
\hline U30 & U3 & 383451109345601 & 0.5 & 69 & - & - & - \\
\hline U31 & $\mathrm{U} 4$ & 383451109345602 & - & - & - & - & - \\
\hline U32 & U5 & 383451109345603 & - & - & 3.3 & -8.1 & 28,000 \\
\hline
\end{tabular}

${ }^{1}$ Data from Nelson, 2017, tables 5 and 7.

${ }^{2} \mathrm{R}$ is the ${ }^{3} \mathrm{He} /{ }^{4} \mathrm{He}$ ratio of the sample, and $\mathrm{Ra}$ is the ${ }^{3} \mathrm{He} /{ }^{4} \mathrm{He}$ ratio of air $\left(1.384 \times 10^{-6}\right)$.

${ }^{3}$ Suspected contamination from naturally occurring crustal sulfur hexafluoride; therefore, age not calculated. 


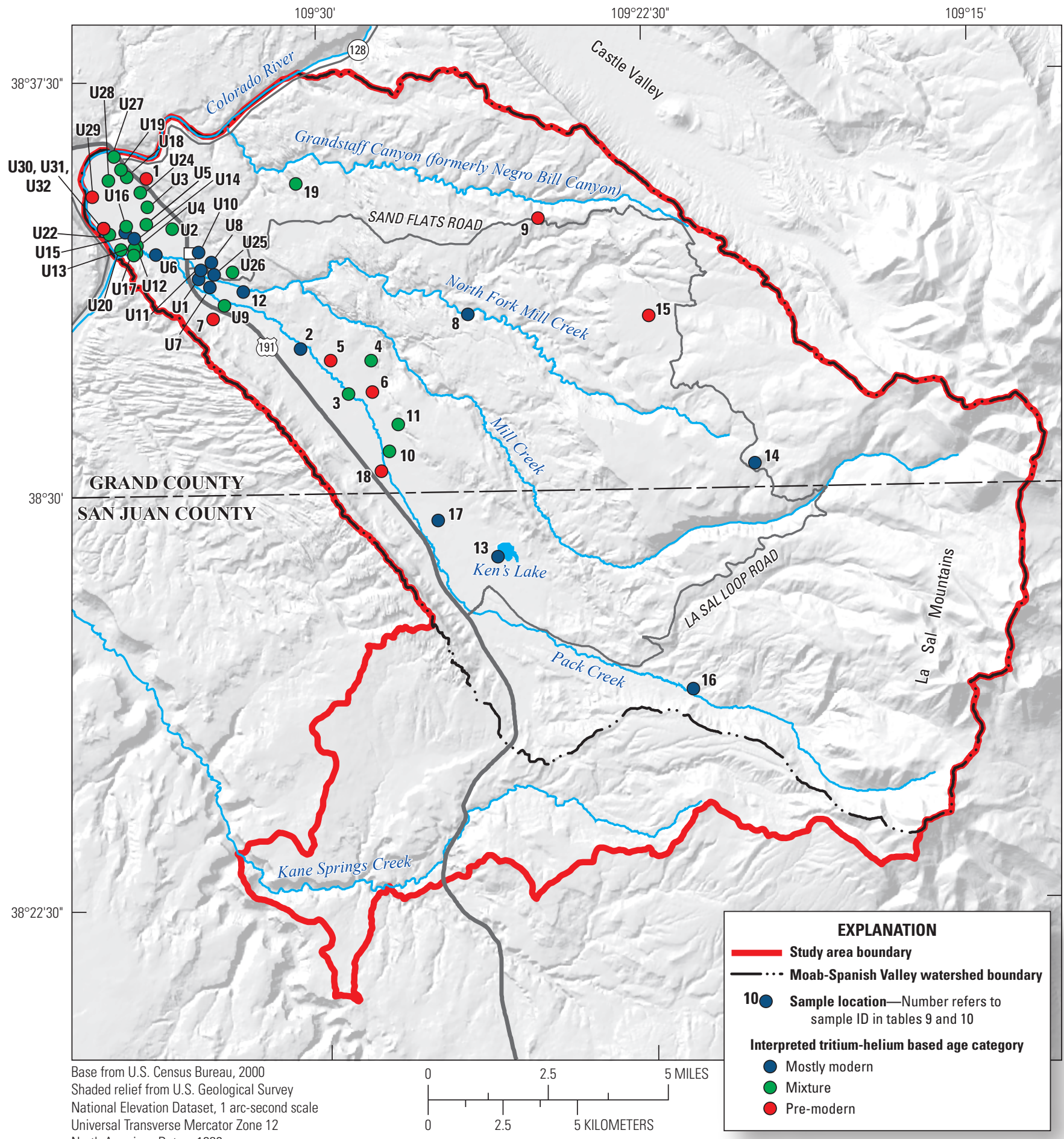

Figure 12. Tritium-helium based age categories of selected samples from wells and springs in the Spanish Valley study area, Utah. 
Tritium to tritiogenic helium-3 ratios were used to calculate apparent ${ }^{3} \mathrm{H} /{ }^{3} \mathrm{He}$ ages for 13 groundwater samples from the GCGA and VFA categorized as mostly modern (table 9). Ages were not calculated for waters characterized as mixtures of modern and pre-modern waters because they are not likely to represent the bulk age of the samples and are unreliable for samples containing elevated terrigenic helium. ${ }^{3} \mathrm{H} /{ }^{3} \mathrm{He}$ ages for the modern groundwaters range from less than 1 to 34.1 years (table 9). Apparent ${ }^{3} \mathrm{H} /{ }^{3} \mathrm{He}$ ages and their uncertainties were calculated for all LVFA samples collected by Nelson (2017; table 10).

Four GCGA samples were categorized as pre-modern (1, 5, 5 (replicate), and 6), three were mixtures of modern and pre-modern $(4,11$, and 19$)$, and one was mostly modern (8), with a ${ }^{3} \mathrm{H} /{ }^{3} \mathrm{He}$ age of 6.3 years (table 9; fig. 12). Sample 4 is from a high-yield well screened in the GCGA and located along the northeast margin of the valley and within about $0.5 \mathrm{mi}$ of Mill Creek, where it could be intercepting a fraction of younger valley-fill groundwater or Mill Creek surface water. Sample 19 is from a spring located near the downgradient end of the GCGA flow system that may contain a small fraction of local (modern) recharge. Sample 8 is from a spring located high in the left-hand fork drainage of Mill Creek and the young age indicates either that recharge to this spring occurs nearby or that flow to this spring occurs through a highly transmissive fracture zone resulting in a short subsurface traveltime. The pre-modern age of most GCGA groundwaters indicates that the residence time of groundwater in this aquifer is predominantly greater than about 60 years at a minimum.

Samples from one mountain spring (14) and one shallow mountain well (16) that were collected in proximity to high-altitude recharge areas were categorized as mostly modern and had ${ }^{3} \mathrm{H} /{ }^{3} \mathrm{He}$ ages of less than 1 and 8.7 years, respectively. Groundwater sampled throughout the VFA in Moab-Spanish Valley is predominantly modern or a modern mixture, most often containing ${ }^{3} \mathrm{H}$ concentrations greater than $1 \mathrm{TU}$ (fig. 12). Five samples with pre-modern waters exist in the valley, generally along the valley margins ( 7 , $18, \mathrm{U} 29, \mathrm{U} 31$, and U32). These samples are distinct in that they are from a bedrock spring (7), a well completed in bedrock underlying the alluvial aquifer (18), or are samples of Paradox Formation brines that underlie fresh water near the Colorado River (U29, U31, and U32). The clear pattern of age categories showing younger water in the VFA and older water in the GCGA provides additional evidence that much of the VFA groundwater is sourced from somewhere other than the GCGA and that it contains, at most, a fraction of GCGA-derived groundwater.

\section{Chlorofluorocarbons and Sulfur Hexafluoride}

Groundwater CFC-11, CFC-12, and CFC-113 concentrations ranged from 1.0 to $989.7,0.0$ to 20,199.3, and 0.0 to 43.5 parts per trillion, volume (pptv), respectively (equivalent atmospheric concentrations; tables 9 and 10). CFC cross-plots are informative regarding potential degradation or contamination of specific CFCs in the groundwater system (fig. 13). If no degradation or contamination occurred, measured CFC concentrations should fall within the region bound by the blue (piston flow), the green (exponential mixing), and the red (binary mixture of older or pre-modern CFC-free groundwater and 2015 recharge) curves of expected air-equilibrated concentrations. CFC-11 concentrations were lower than expected relative to CFC-12 concentrations for most samples with measured data points falling to the right and below the expected air-equilibrated curves (fig. 13). The same pattern (data points falling to the right and below the expected air-equilibrated curves) was observed in plots of CFC-113 compared to CFC-12. Lower than expected concentrations of CFC-11 and CFC-113 may have been caused by preferential microbial degradation under anaerobic conditions, as previously described by Plummer and Busenberg (2000). Only four samples (9, 15, 17, and 18) plot near or within the envelope created by the blue (piston flow) and red (binary mixing) lines (fig. 13), indicating noncontaminated or non-degraded CFC-11.

A cross-plot of CFC-12 and ${ }^{3} \mathrm{H}$ was used to evaluate CFC-12 contamination from non-atmospheric sources. Assuming ${ }^{3} \mathrm{H}$ is conservative and atmospherically sourced, figure 14 shows that several samples are outside (to the left) of the region bounded by red (binary mixing) and blue (piston flow) air-equilibrated curves, indicating CFC-12 contamination. This finding is corroborated by figure 13 where samples $(1,2$, and 10) plot above expected atmosphericsolubility concentrations indicating contamination of both CFC-11 and CFC-12. Because of potential contamination of all CFCs and degradation of CFC-11 and CFC-113, CFCs were selected as tracers in final age models only after careful consideration and when multiple tracers were in good agreement.

Groundwater $\mathrm{SF}_{6}$ concentrations corrected for excess-air range from less than 0 to $3.9 \mathrm{pptv}$ (equivalent atmospheric concentrations; table 9). A cross-plot of $\mathrm{SF}_{6}$ and ${ }^{3} \mathrm{H}$ was used to evaluate $\mathrm{SF}_{6}$ contamination from non-atmospheric sources (fig. 15). Six samples $(1,6,9,11,12$, and 15) plotted to the left and outside the area bound by the blue (piston flow) and red (binary mixing) air-equilibrated curves, and therefore contained excess $\mathrm{SF}_{6}$. Data collected by Nelson (2017) (fig. 16; table 10), showed an increase in this excess $\mathrm{SF}_{6}$ at the lower (northern) end of Spanish Valley. A possible source is naturally occurring crustal $\mathrm{SF}_{6}$, as documented in other studies (Koh and others, 2007). Because of this excess, $\mathrm{SF}_{6}$ was only used for dating of a small number of sites in the upper part of the study area. 


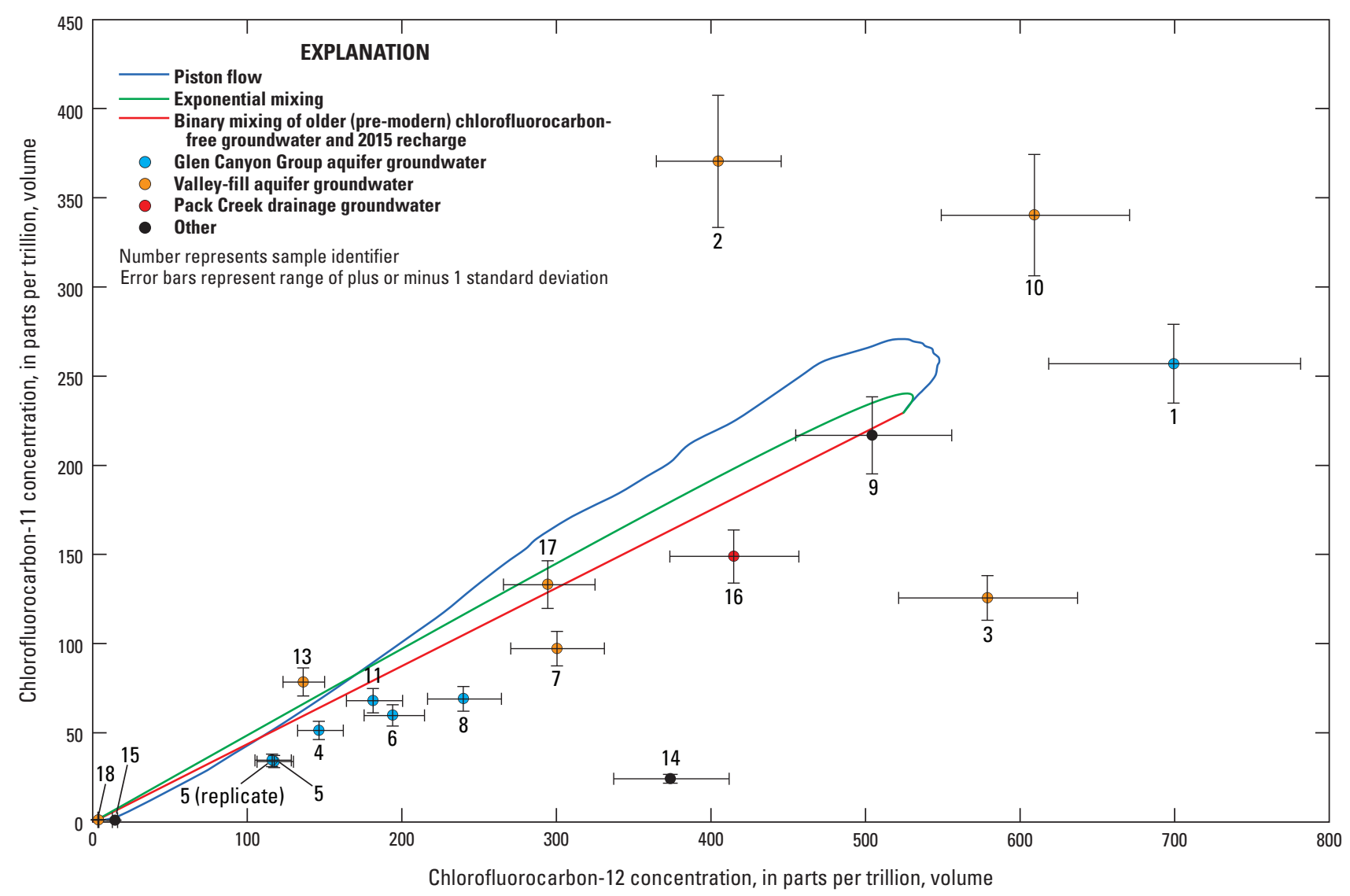

Figure 13. Concentrations of chlorofluorocarbon-11 compared to chlorofluorocarbon-12 in selected groundwater samples from the Spanish Valley study area, Utah.

\section{Carbon-14}

Carbon-14 activity measured from DIC in groundwater samples from 22 sites within the study area range from 3.3 to $98 \mathrm{pmC}$, giving unadjusted radiocarbon ages from 200 to 28,000 years old (tables 9 and 10 ). GCGA groundwater samples $(1,4,5,6,8,11$, and 19) had a narrow range of ${ }^{14} \mathrm{C}$ values of 50 to $63 \mathrm{pmC}$ and corresponding unadjusted ages of 3,800 to 5,700 years. GCGA groundwater sampled from a spring in the upper part of Left-Hand Fork of Mill Creek (8) had $52 \mathrm{pmC}$ of ${ }^{14} \mathrm{C}$ and an unadjusted radiocarbon age of 5,400 years, indicating that it contains a component of pre-modern water, despite being categorized as mostly modern based on ${ }^{3} \mathrm{H}$ and ${ }^{3} \mathrm{He}$. Except for one bedrock spring that discharges along the southwest valley margin (sample 7; $52 \mathrm{pmC}$ ), samples from the VFA had ${ }^{14} \mathrm{C}$ values from 65 to $95 \mathrm{pmC}$ and corresponding unadjusted ages of 410 to 3,600 years. The consistently higher ${ }^{14} \mathrm{C}$ and younger unadjusted ages of the VFA groundwater when compared to GCGA groundwater provide yet another line of evidence that the VFA receives substantial recharge from a source other than the GCGA.

Two samples (15 and U32; tables 9 and 10) stand out as having notably lower ${ }^{14} \mathrm{C}$ pmC and older unadjusted radiocarbon ages than most of the other samples. Sample 15 is from a deep bedrock well located on Wilson Mesa. Water from this well had only $22 \mathrm{pmC}$ of ${ }^{14} \mathrm{C}$ and an unadjusted age of 13,000 years, indicating that it may not be in connection with the adjacent (down-gradient) GCGA to the west, which consistently contains water with twice the ${ }^{14} \mathrm{C} \mathrm{pmC}$ that is half the age. Sample U32 is from a well completed in valley-fill sediments saturated with a brine derived from the Paradox Formation that underlies freshwater near the Colorado River. This brine sample has only $3.3 \mathrm{pmC}$ of ${ }^{14} \mathrm{C}$ and an unadjusted age of 28,000 years, indicating that the brine is likely stagnant beneath the active, overlying freshwater aquifer. On the other hand, samples from two springs (9 and 14) and one shallow well (16), thought to be near their respective recharge areas, had high ${ }^{14} \mathrm{C}$ values of 91,98 , and $77 \mathrm{pmC}$, respectively, as expected for waters with relatively short residence times. Patterns of uncorrected ${ }^{14} \mathrm{C}$ ages and relative groundwater are useful in characterizing aquifer systems. GCGA groundwater is markedly older (average uncorrected age $\pm 1 \sigma=4,900 \pm 730$ years) than water from the VFA (1,600 $\pm 1,100$ years), except for one spring (sample 7) discharging from bedrock along the southwest margin of the valley that is hydraulically disconnected from the GCGA on the northeast side of the valley. 


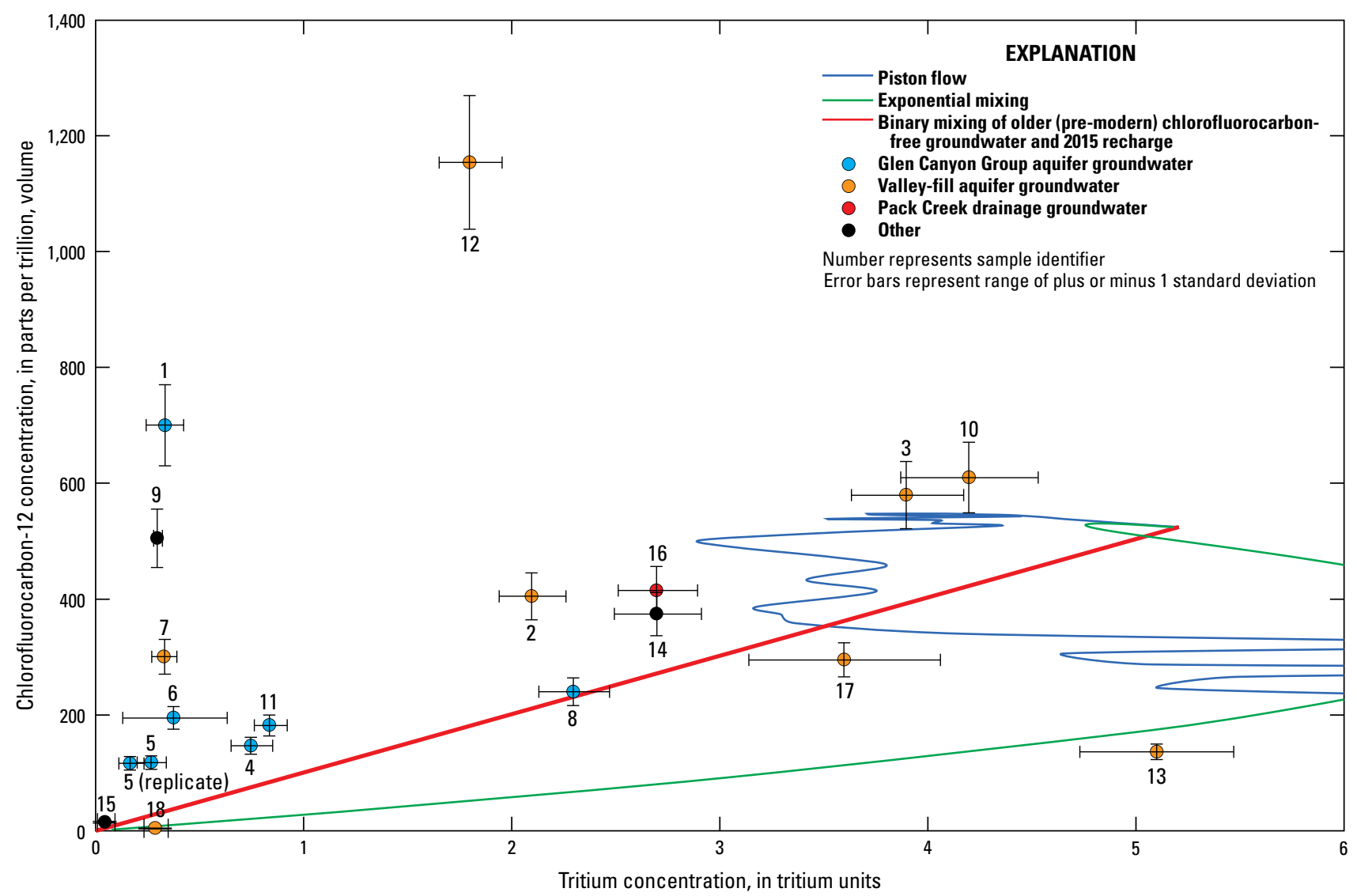

Figure 14. Concentrations of chlorofluorocarbon-12 compared to tritium in selected groundwater samples from the Spanish Valley study area, Utah.

Prior to the use of ${ }^{14} \mathrm{C}$ in determination of absolute ages, geochemical corrections of ${ }^{14} \mathrm{C}$ are likely needed. A correlation between $\delta^{13} \mathrm{C}$ enrichment (values becoming less negative) and decreasing ${ }^{14} \mathrm{C}$ pmC (fig. 17) indicates that significant watercarbonate mineral reactions occur in these aquifers and that unadjusted radiocarbon ages are likely biased old. A notable result of the comparison is that GCGA waters plot together in a cluster below the dominant pattern, with GCGA waters having lower ${ }^{14} \mathrm{C}$ values than all other samples with similar $\delta^{13} \mathrm{C}$ (fig. 17). This could indicate that less water-carbonate mineral reaction occurs in the sandstone of the GCGA than elsewhere in the study area, and that bias in uncorrected ${ }^{14} \mathrm{C}$ age is not as large for GCGA groundwater.

Geochemical processes other than radio-decay affected groundwater ${ }^{14} \mathrm{C}$ activities in the study area and unadjusted ${ }^{14} \mathrm{C}$ ages are likely biased old. Following the graphical interpretations of Han and others (2012), all of the samples were likely most affected by open-system conditions with free exchange between soil gas and atmosphere. Corrected final ${ }^{14} \mathrm{C}$ concentrations were calculated using the appropriate formulation (open or closed system) of the revised Fontes and Garnier model (table 9). Seven samples (1, 4, 6, 7, 8,11 , and 15) plotted below the so called zero-age line (Han and Plummer, 2016), indicating high confidence in the corrected ${ }^{14} \mathrm{C}$ age.
Preliminary modeling results indicated a negative age (measured ${ }^{14} \mathrm{C}$ greater than modeled ${ }^{14} \mathrm{C}$ at the water table) for some of the samples $(3,9,10,12,14$, and 16) indicating an over-correction of final ${ }^{14} \mathrm{C}$ concentrations. Temporal variability in ${ }^{14} \mathrm{C}$ of unsaturated zone $\mathrm{CO}_{2}$ resulting from atmospheric variability, and thus uncertainty in geochemical model inputs, is one possible explanation. An unsaturated zone gas value of $140 \mathrm{pmC}$ used for five of these sites (table 9) was based on reconstructed atmospheric concentrations of ${ }^{14} \mathrm{C}$ (Jurgens and others, 2012), and represents a component of 'bomb-pulse' atmospheric ${ }^{14} \mathrm{C}$ in the sampled groundwater. A value of $145 \mathrm{pmC}$ was used for the remaining sample (12) to bring the measured ${ }^{14} \mathrm{C}$ to a value less than the initial modeled ${ }^{14} \mathrm{C}$. More detailed investigation and modeling to improve conceptualization and ${ }^{14} \mathrm{C}$ geochemical corrections was beyond the scope of this study. Despite the uncertainty in specific geochemical processes, the clear signal of nonatmospheric ${ }^{14} \mathrm{C}$ (fig. 17) indicates that the use of corrected ${ }^{14} \mathrm{C}$ concentrations in the calculation of estimated groundwater age is likely an improvement over using uncorrected ${ }^{14} \mathrm{C}$ concentrations. 


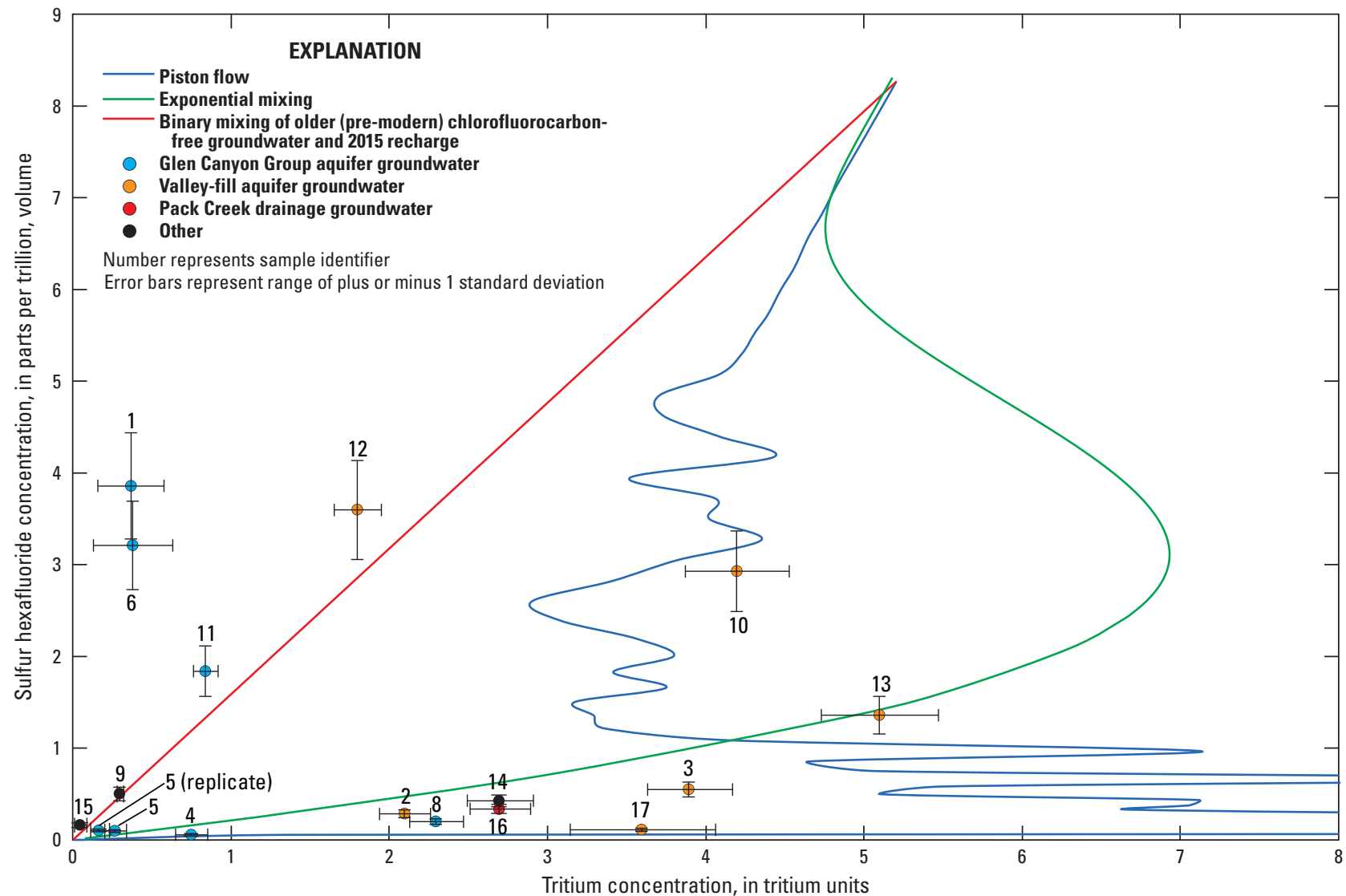

Figure 15. Concentrations of sulfur hexafluoride compared to tritium in selected groundwater samples from the Spanish Valley study area, Utah. 


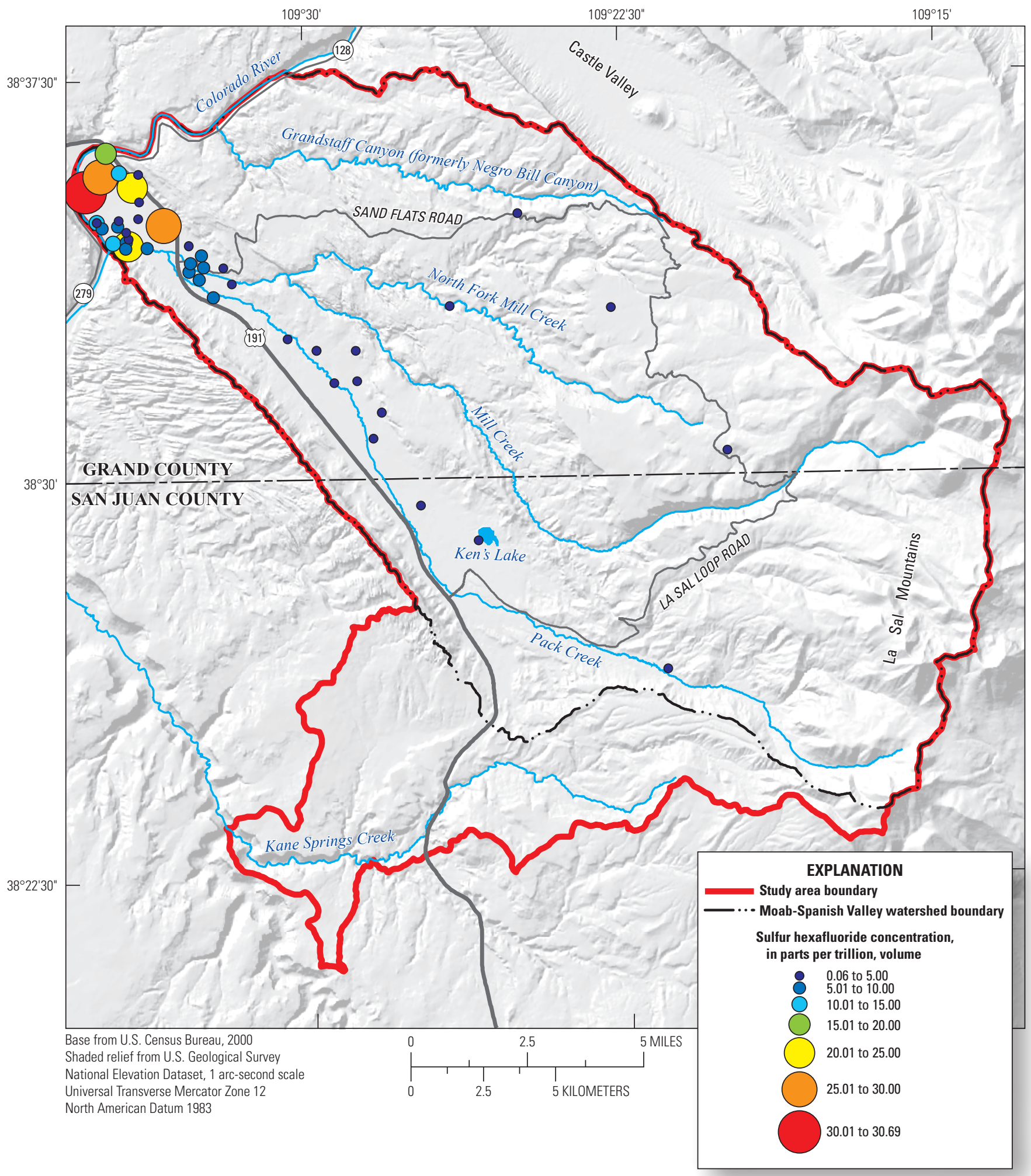

Figure 16. Concentrations of sulfur hexafluoride in groundwater samples from the Spanish Valley study area, Utah. 


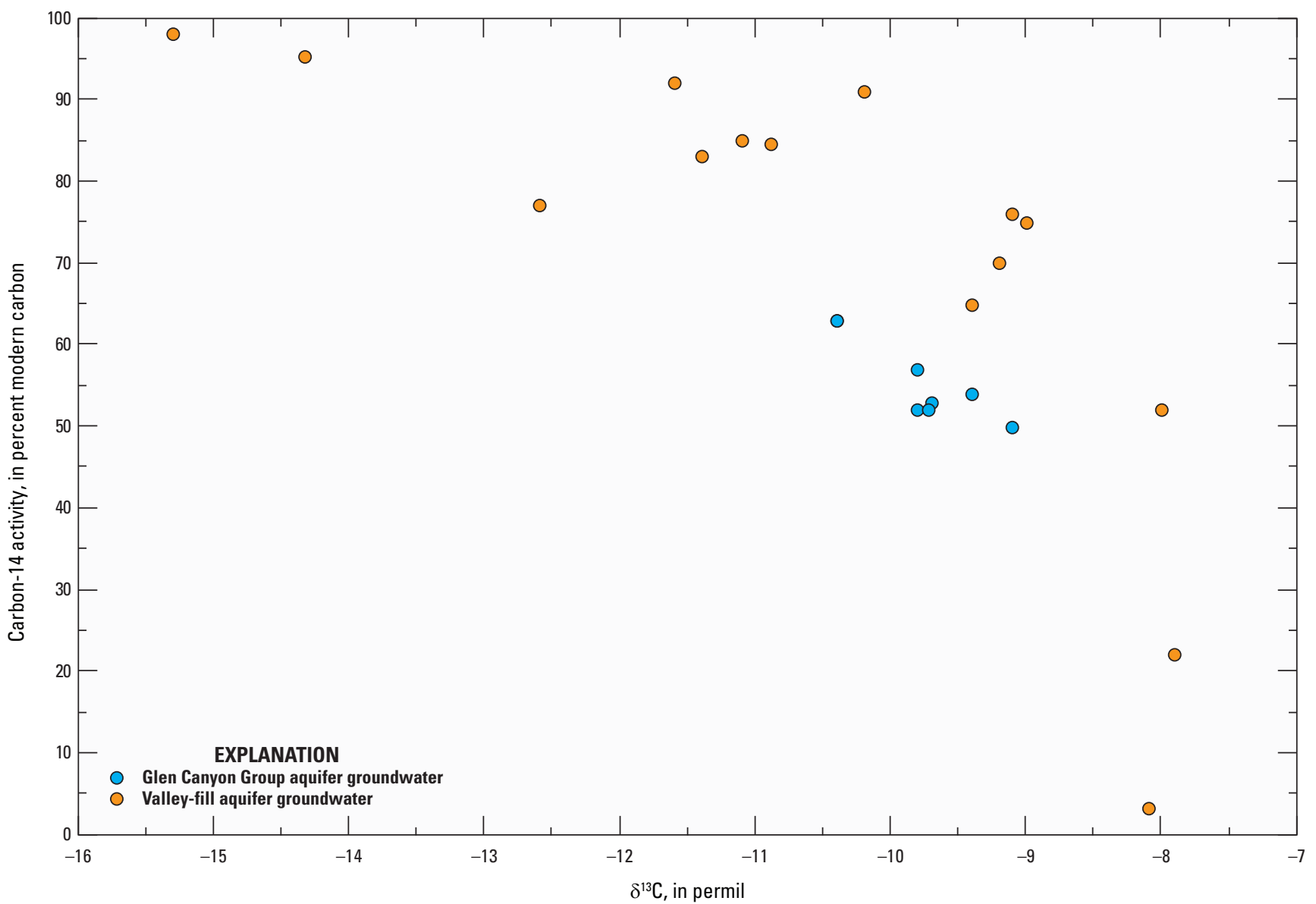

Figure 17. Carbon-14 $\left({ }^{14} \mathrm{C}\right)$ activity compared to $\delta^{13} \mathrm{C}$ for groundwater samples from the Spanish Valley study area, Utah.

\section{Conceptual Groundwater-Flow System Recharge}

The current study considers all forms of recharge to and discharge from the groundwater system, including the La Sal Mountains. This is illustrated by considering the fate of recharge from direct infiltration of mountain precipitation (fig. 18, R1). Part of this recharge moves directly through the subsurface from the mountain block into the adjacent GCGA and PCD. Another part of this recharge becomes groundwater discharge to streams (fig. 18, D1). A fraction of this mountainblock groundwater discharge is consumptively lost to evapotranspiration, both in the mountains and as this water enters the valley in streams, and a fraction of the remaining water in the streams, combined with surface-water runoff becomes recharge to the VFA (fig. 18, R2). Groundwater in the GCGA and VFA ultimately discharges in the valley lowlands to streams and springs (fig. 18, D1 and D2), wells (fig. 18, D3), as evapotranspiration (fig. 18, D4), or as subsurface outflow to the Colorado River (fig. 18, D5).
Precipitation within the study area is the primary source of groundwater recharge. The majority of precipitation comes as winter snowfall on the mountain ranges, with lesser amounts falling as rain. Although recharge to both the GCGA and the VFA originates as precipitation, the GCGA and the VFA have distinct geochemical characteristics, which indicate that there are separate sources and (or) mechanisms of recharge to each aquifer, and that there is limited connectivity between the GCGA and the VFA. The environmental tracers and geochemistry previously described help to (1) characterize and group waters; (2) provide insight into what type of geology was encountered; (3) indicate the altitude and temperature of recharge; and (4) determine the age of the groundwater (or the elapsed time since recharge).

Recharge to the GCGA occurs as direct infiltration of precipitation at high altitudes in the La Sal Mountains, likely from snowmelt (fig. 18, R1). This is shown by the stable isotope ratios of $\delta \mathrm{D}$ and $\delta^{18} \mathrm{O}$ for the GCGA (fig. 9), which are isotopically lighter than most other samples analyzed during this study. Precipitation falling directly on the Sand Flats area does not contribute significantly to GCGA recharge. 
Groundwater budget = R1 + R2 - D1 - D2 - D3 - D4 - D5

$\mathrm{R} 1=$ Recharge from precipitation

R2 = Recharge from runoff, losing reaches of streams, and unconsumed surface-water and groundwater irrigation

D1 = Discharge to gaining reaches of streams

D2 = Discharge to springs

D3 = Discharge to well withdrawals

D4 = Discharge to evapotranspiration

D5 = Discharge to subsurface outflow to Colorado River

\section{EXPLANATION \\ $\leftarrow$ Recharge \\ $\leftarrow$ Discharge \\ $\leftarrow$ Direction of groundwater flow}

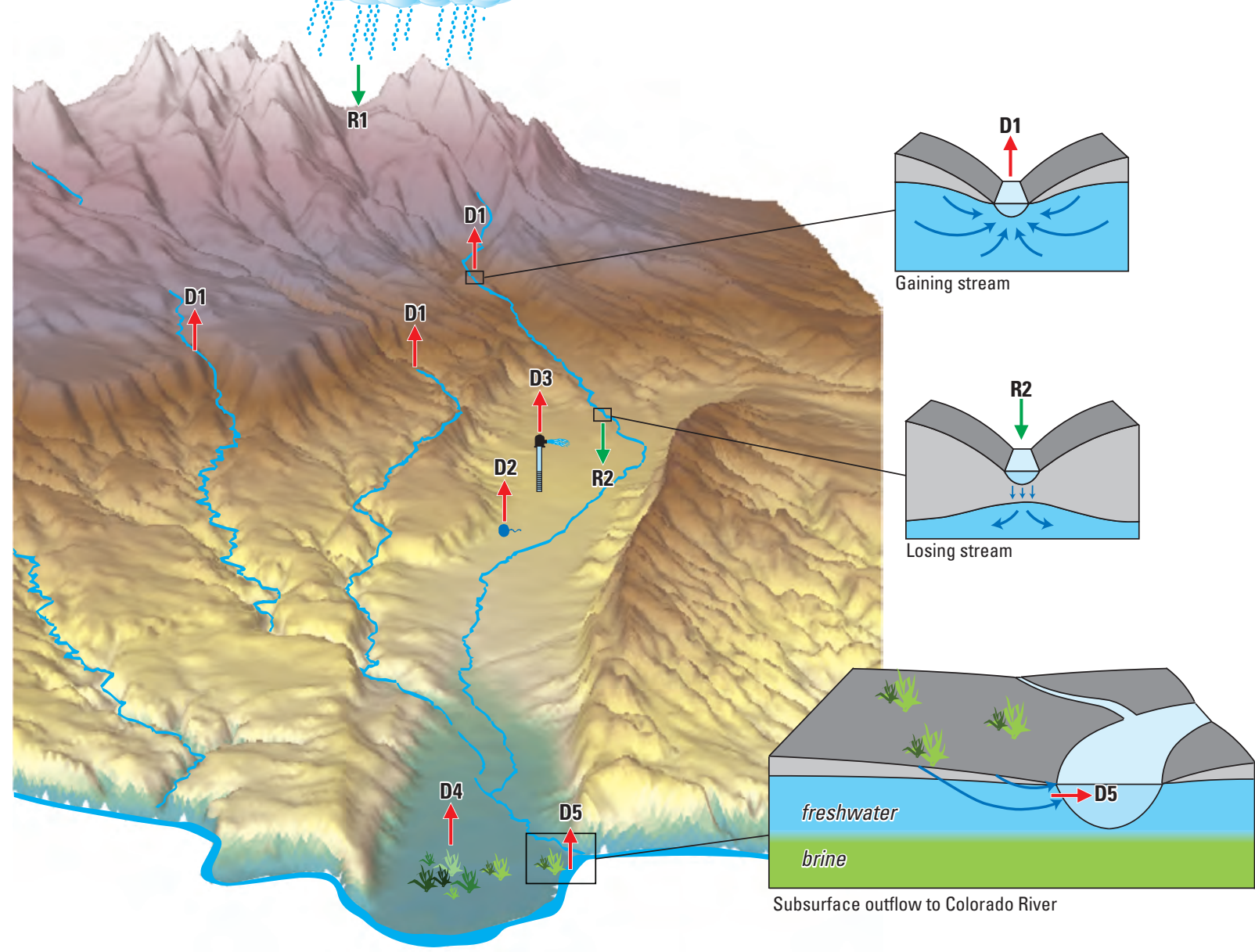

Figure 18. Conceptualization of the groundwater flow system and budget components for the Spanish Valley study area, Utah. 
Recharge to the VFA occurs largely from losing reaches of Pack Creek or from water recharging in the Pack Creek drainage (fig. 18, R2); the geochemical type of the VFA groundwater $\left(\mathrm{CaSO}_{4}\right)$ is similar to water from Pack Creek (pl. 2). Some mixing of GCGA water with VFA water in the valley is possible, as is evident from dilution along the eastern margin of the valley, or lower TDS down valley (pl. 2). Noble gas temperatures indicate that precipitation falling directly on the valley floor provides little to no recharge to the VFA (fig. 11), but rather that groundwater recharged at higher altitudes than the valley floor. Recharge to the VFA also can occur from unconsumed surface-water or groundwater irrigation (fig. 18, R2).

\section{Movement}

A water-level surface map was developed for the study area to show general directions of groundwater movement (pl. 3). Control points used in the water-level map include (1) water levels measured in 77 wells in February and March 2016; (2) stream altitudes from gaining sections of Mill Creek, North Fork Mill Creek, and surface water in Negro Bill canyon, and from losing sections of upper Pack Creek; and (3) spring altitudes. For wells that were completed at multiple depths, the water level from the shallowest depth was used in the water-level surface map.

General directions of groundwater movement in the VFA and in the GCGA are from the southeast to the northwest towards the Matheson Wetlands and the Colorado River. In the VFA, groundwater flow is away from Pack Creek in the upper section of the drainage where it is a losing stream, and towards Pack Creek in the lower sections of the drainage where it is a gaining stream. In the Matheson Wetlands, flow is towards the northwest in the upgradient part of the wetlands, and then turns towards the west and southwest towards the Colorado River in the downgradient part of the wetlands. In the upper PCD, flow is also towards the northwest, whereas in the Kane Springs Creek drainage, flow is generally to the southwest. The water-level data indicate a potential groundwater divide between the Pack Creek and Kane Springs Creek drainages. There also is a difference in geochemical water types between PCD groundwater $\left(\mathrm{CaSO}_{4} ; \mathrm{pl} .2\right)$ and Kane Springs Creek drainage groundwater $\left(\mathrm{CaCO}_{3} ; \mathrm{pl} .2\right)$. Because of the lack of water-level data in this area, however, the location of the divide cannot be precisely determined.

\section{Water-Level Fluctuations}

The locations of 10 wells with long-term (26 years or greater) annual spring season water-level records are shown in figure 19. Hydrographs of spring season water-levels in these wells are shown in figure 20. Wells 1, 3, 4, and 9 are completed in the VFA. Wells 6, 7, 8, and 10 are completed in the GCGA. The aquifer of completion for wells 2 and 5 are unknown; well logs were unavailable for these two wells. Well logs for other wells near wells 2 and 5, however, indicate that the wells are likely completed in the VFA.

A graph of the cumulative departure from average annual precipitation at Moab, Utah is also shown in figure 20 (data accessed September 25, 2017, at https://wrcc.dri.edu/ cgi-bin/cliMAIN.pl?ut5733). A positive departure (or greater than annual precipitation) for a year results in an upward trending segment in the graph; a negative departure (or less than average precipitation) for a year results in a downward trending segment in the graph. Annual spring season water levels in the study area generally respond to fluctuations in precipitation, but can lag about 1 or 2 years. Water levels generally declined during the 1970 s, corresponding to a period of below average precipitation in the area (fig. 20). Most of the wells showed water levels increasing in the 1980s, and had maximum levels in 1989, corresponding to a large increase in precipitation to near-average or above-average conditions in the mid-to-late 1980s (fig. 20). Water levels generally increased or remained constant during the 1990s, and then declined from the early to mid-2000s, corresponding to a slight decrease in precipitation (fig. 20). Water levels generally increased slightly or remained constant from 2005 to 2011, and then declined steadily until 2015, corresponding to a decrease in precipitation (fig. 20). Between 2015 and 2017, water levels in most wells increased slightly, corresponding to an increase in precipitation (fig. 20).

\section{Discharge}

Discharge from the groundwater system for both the GCGA and VFA occurs as discharge to streams or base flow (fig. 18, D1), springs (fig. 18, D2), well withdrawals (fig. 18, D3), by evapotranspiration mainly along the stream reaches or in the wetland (fig. 18, D4), and as subsurface outflow to the Colorado River (fig. 18, D5). The majority of discharge within the study area occurs as discharge to streams and springs. 


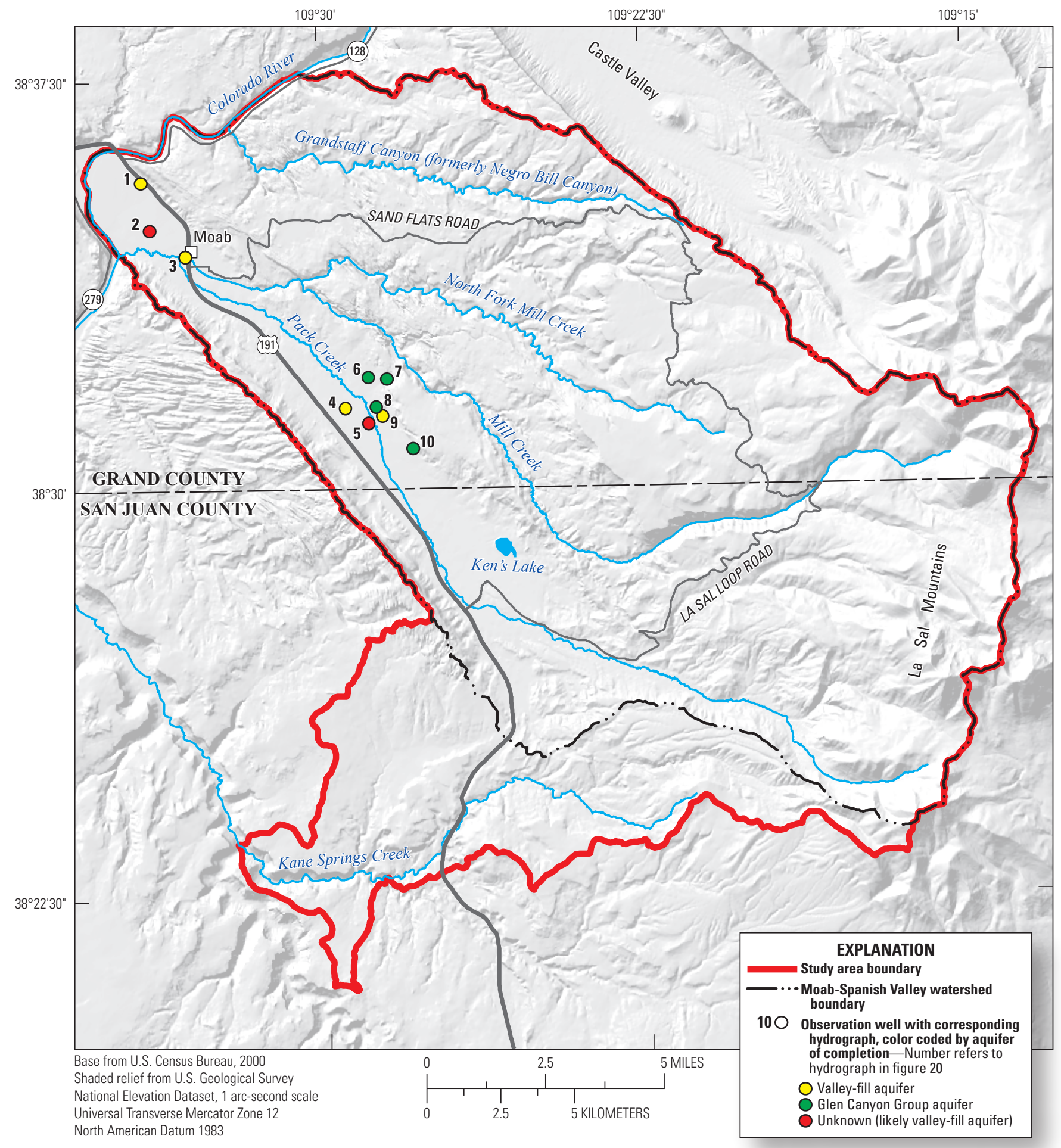

Figure 19. Location of wells in the study area that have long-term (26 years or greater) annual (spring season) water-level records in the Spanish Valley study area, Utah. 

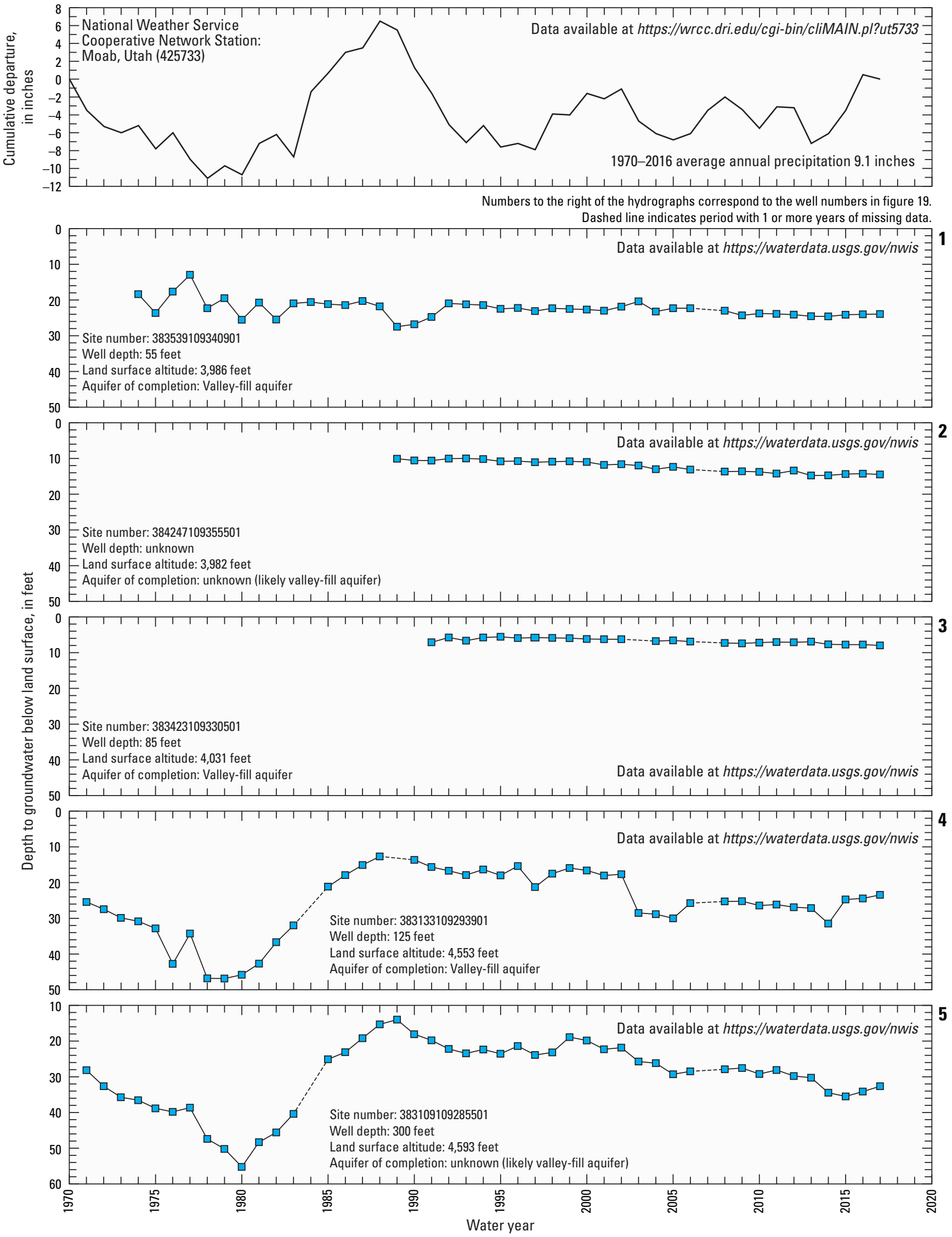

Figure 20. Cumulative departure from average annual precipitation at Moab and annual (spring season) water-level hydrographs in wells with long-term (26 years or greater) water-level records in the Spanish Valley study area, Utah. 

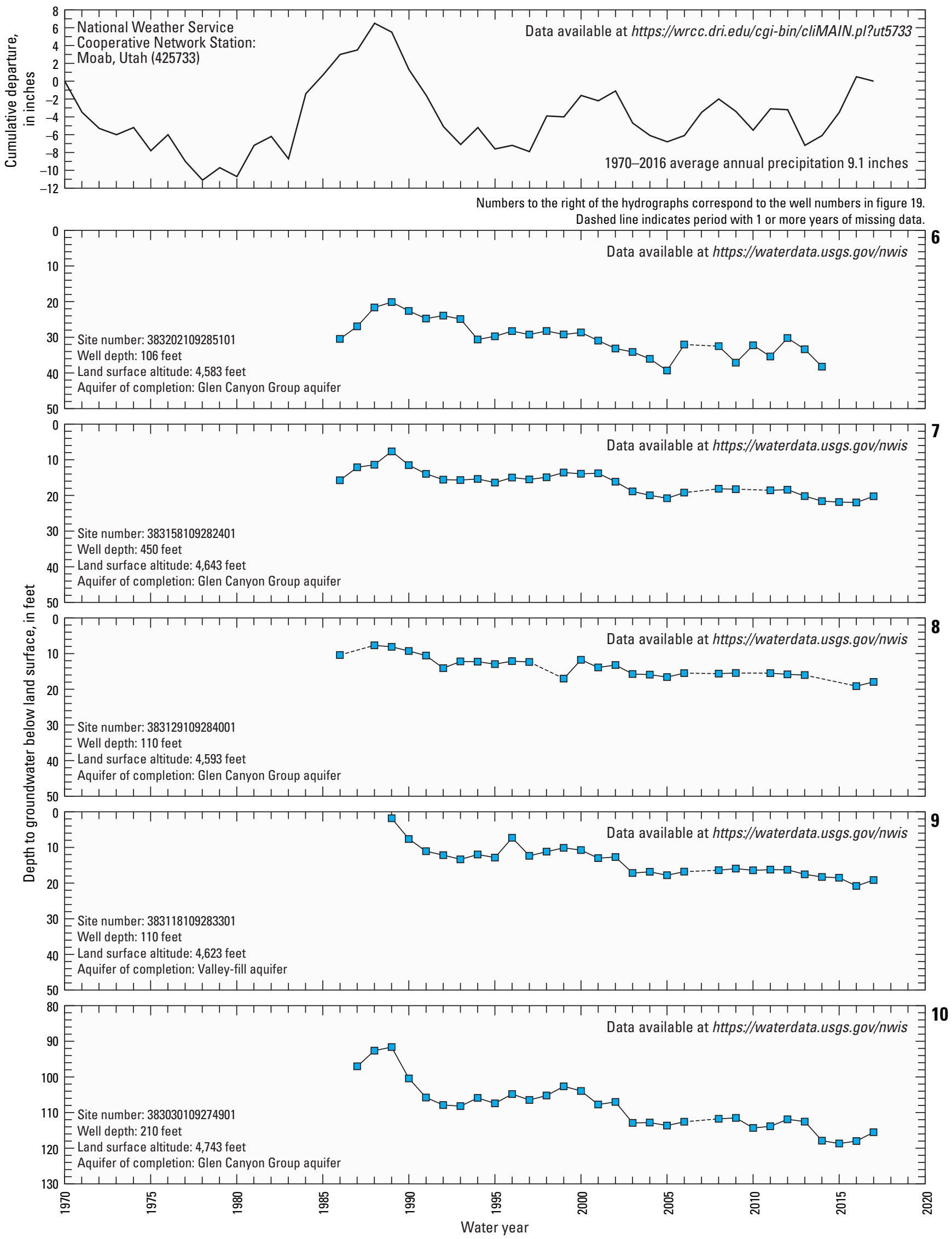

Figure 20. Cumulative departure from average annual precipitation at Moab and annual (spring season) water-level hydrographs in wells with long-term (26 years or greater) water-level records in the Spanish Valley study area, Utah.-Continued 


\section{Groundwater Budget}

The groundwater budget for the current study was compiled from a number of different estimates and methods. Groundwater budget components were estimated only for the Moab-Spanish Valley watershed part of the study area, based on the assumption that a groundwater divide is present between the Moab-Valley watershed and the Kane Springs Creek watershed (table 11). Average annual recharge estimates from precipitation are from 1940-2012, while discharge estimates were a combination of spring and streamflow measurements made during the fall of 2014, 2015, and 2016, reported spring and well withdrawals for 2014, 2015, and 2016, and subsurface outflow estimates made using data collected in the wetland in 2015 and 2016. Annual precipitation at Moab, Utah (data accessed September 25, 2017, at https://wrcc.dri.edu/cgi-bin/cliMAIN.pl?ut5733) in 2013-15 was 12 to 44 percent above average, whereas annual precipitation in 2016 was about 6 percent below average. Because precipitation was above average for most of the study period, discharge estimates may be slightly higher than long-term average annual discharge amounts for the groundwater system.

\section{Recharge}

\section{Precipitation}

Two different methods of estimating recharge from precipitation were used in this study. The first method, known as the Basin Characterization Model (BCM), was used to determine estimates of recharge for the entire Moab-Spanish
Valley watershed part of the study area. The second method estimated recharge over areas of the Glen Canyon Group and Entrada Sandstone using the net-infiltration map in combination with the CMB and TDTP methods of estimating net-infiltration at the borehole sites (see sections "Chloride and Bromide" and "Tritium and Moisture Content" under "VadoseZone Environmental Tracers" in this report).

\section{Basin Characterization Model}

A regional-scale water-balance method, known as the BCM (Flint and Flint, 2007) developed for the Upper Colorado River Basin (A. Flint, written commun., November 2014) was used to provide estimates of average annual recharge from direct infiltration of precipitation (in-place recharge) and runoff. The BCM is a distributed parameter water-balance accounting model used to identify areas having climatic and geologic conditions that allow for precipitation to become potential in-place recharge or runoff, and to provide estimates of each (Flint and others, 2011; Masbruch and others, 2011). BCM in-place recharge is calculated as the volume of water per time that percolates through the soil zone past the root zone and becomes net infiltration to consolidated rock or unconsolidated deposits. Runoff is the volume of water per time that runs off the surface, and may (1) infiltrate the subsurface, (2) undergo evapotranspiration further downslope, or (3) become streamflow that can, in turn, recharge the unconsolidated deposits from infiltration beneath the stream channels, irrigation canals, and (or) fields irrigated with surface water (Masbruch and others, 2011). The BCM does not track or route runoff. The BCM calculations are made on a $270-\mathrm{m}$ grid for each water year from 1940 to 2012.

Table 11. Annual 2014, 2015, and 2016, and average annual groundwater budgets for the Moab-Spanish Valley watershed part of the Spanish Valley study area, Utah.

[Annual volume in acre-feet per year, rounded. Abbreviation: N/A, not applicable]

\begin{tabular}{|c|c|c|c|c|c|}
\hline Recharge & 2014 & 2015 & 2016 & $\begin{array}{c}\text { Average } \\
\text { annual }\end{array}$ & $\begin{array}{c}\text { Uncertainty } \\
\text { (percent) }\end{array}$ \\
\hline Direct infiltration of precipitation (in-place recharge) ${ }^{1}$ & N/A & $\mathrm{N} / \mathrm{A}$ & $\mathrm{N} / \mathrm{A}$ & 9,000 to 27,000 & ${ }^{2} 50$ \\
\hline Unconsumed irrigation from well withdrawals & 25 to 125 & 8 to 40 & 9 to 45 & N/A & unknown \\
\hline Total: & & & & 9,550 to 30,000 & \\
\hline Streams and springs (base flow) & 10,600 & 11,700 & 10,200 & N/A & ${ }^{3} 5$ \\
\hline Springs and well withdrawals for culinary use & 2,400 & 3,000 & 3,300 & $\mathrm{~N} / \mathrm{A}$ & unknown \\
\hline Well withdrawals for irrigation (net depletion) & 250 & 80 & 89 & N/A & unknown \\
\hline Subsurface outflow & N/A & N/A & $\mathrm{N} / \mathrm{A}$ & 300 to 1,000 & ${ }^{4} 40-50$ \\
\hline
\end{tabular}

${ }^{1}$ Represents average annual values of in-place recharge and recharge from runoff from 1940-2012 from the Basin Characterization Model.

${ }^{2}$ Based on sensitivity analysis of the Basin Charactrization Model documented in Flint and others (2011) and Masbruch and others (2011).

${ }^{3}$ Average of assumed measurement error.

${ }^{4}$ Based on average error of transmissivity estimates for hydraulic-gradient method, and errors in age difference and distance for the age-gradient method. 
In-place recharge is calculated at the location as it occurs in the BCM (fig. 21). The highest amounts of in-place recharge occur in the La Sal Mountains with lesser amounts occurring along the margins or in Moab-Spanish Valley. Sensitivity analyses of BCM in-place recharge rates indicate that the uncertainties of these rates are about 50 percent (Flint and others, 2011; Masbruch and others, 2011). Thus, the average annual (1940-2012) in-place recharge calculated by the BCM in the Moab-Spanish Valley watershed was between 9,000 and 27,000 acre-ft (table 11).

The BCM calculates runoff where it originates (fig. 22). The highest amounts of runoff originate in the La Sal Mountains, especially in areas where the Tertiary intrusive volcanics are at or near the surface (pl. 1). The BCM does not route runoff; however, runoff that originates at higher altitudes likely becomes streamflow and recharges areas along losing reaches of the streams or farther down in the valley where surface water is used for irrigation. The average annual (1940-2012) total runoff calculated by the BCM in the Moab-Spanish Valley watershed was about 5,100 acre-ft. The amount of runoff that infiltrates the subsurface and recharges the groundwater system is typically calculated as a percentage of the total BCM runoff, and can be difficult to determine. Previous studies that have used the BCM (Hevesi and others, 2003; Belcher and others, 2004; San Juan and others, 2004; Masbruch and others, 2011) have assumed recharge from runoff percentages of 10 to 50 percent, depending on how much irrigation is supplied from surface water. Furthermore, irrigation with surface water is assumed to increase recharge because the water is removed from armored natural stream channels and spread onto fields (Masbruch, 2011). Irrigation return flow studies near Milford, Utah, showed that recharge on flood-irrigated fields can be as high as 50 percent of the applied irrigation (Susong, 1995). Using this range of 10 to 50 percent, the average annual recharge from runoff, which includes recharge from losing reaches of streams and from the infiltration of unconsumed surface-water irrigation, is assumed to be between 510 and 2,550 acre- $\mathrm{ft}$ (table 11).

\section{Sandstone Net-Infiltration Mapping}

Net-infiltration (recharge) rates on the sandstone outcrop areas, unfortunately, could only be determined at one of the four borehole core sites (site C, fig. 6). The perched water encountered at a depth of about $50 \mathrm{ft}$ at sites $\mathrm{A}$ and $\mathrm{D}$ and the low tritium concentrations at site B indicates little or no infiltration is occurring at these locations (fig. 6). The net-infiltration rate at site $\mathrm{C}$ is estimated to range from 14 to 35 millimeters per year ( $\mathrm{mm} / \mathrm{yr}$ ), based on the CMB and TDTP methods, respectively. The estimated GIS-based netinfiltration rate at this site $(20 \mathrm{~mm} / \mathrm{yr}$, or about 10 percent of precipitation) is within this range. This indicates that the GIS-based net-infiltration mapping method developed for southwestern Utah is applicable for the Glen Canyon Group and Entrada Sandstone outcrop areas in the Spanish Valley study area without perched water. Unfortunately, the map could not be adequately calibrated because of only one calibration point. In contrast, the net-infiltration map for southwestern Utah was calibrated by net-infiltration rates from 11 borehole sites. Also, the GIS method cannot be used for ephemeral washes such as site B. Recharge to the GCGA from infiltration of precipitation on the exposed sandstone outcrop areas, therefore, could not be estimated using the GIS-based methods. Additional borehole environmental tracer data are needed to evaluate the extent of perching in the sandstone outcrop area. The combination of perched water in the vadose zone (sites A and D) and low infiltration beneath the ephemeral wash (site B), however, indicate that the amount of recharge is less than the approximately 10 percent of precipitation estimated for the Navajo Sandstone outcrop area of southwestern Utah. The infiltration that accumulates in the perched zone found at sites A and D likely moves laterally towards canyon walls where it discharges to springs and hanging gardens. This finding is consistent with the depleted stable-isotope signatures of the GCGA groundwater samples (fig. 9), indicating that little recharge to the aquifer occurs along the lower-altitude outcrop areas.

\section{Unconsumed Irrigation From Well Withdrawals}

It is assumed that some part of the well withdrawals used for irrigation recharges the aquifer system as infiltration of unconsumed irrigation water applied to fields. This irrigation return flow is difficult to quantify and varies on a number of factors including the type of irrigation (sprinkler compared to flood) and local soil properties. Irrigation return flow studies have reported that between about 10 and 50 percent of water used for irrigation in similar climatic and hydrologic settings is not consumed by crops and becomes recharge to the groundwater system (Feltis, 1967; Clark and Appel, 1985; Stolp, 1994; Susong, 1995). Irrigated fields in the study area use both sprinkler and flood type irrigation. Using the range of 10 to 50 percent, the total annual amount of recharge from unconsumed irrigation from well withdrawals from 2014-16 ranged from 8 to 125 acre-ft (table 11).

\section{Discharge}

Groundwater discharge to streams and lower Spanish Valley spring flow measurements were made in the fall and represent base flow conditions. These estimates, therefore, represent a minimum estimate of groundwater discharge to streams and the lower valley springs. Higher amounts of base flow may occur during times of higher streamflow, such as during the snowmelt period. Separating the groundwaterderived part of this higher streamflow, however, is extremely difficult, especially in snowmelt-dominated regions where standard graphical base-flow separation techniques do not work. Likewise, higher spring flows may occur at other times of the year, as the yearly snowmelt-derived recharge pulse moves through the groundwater system. 


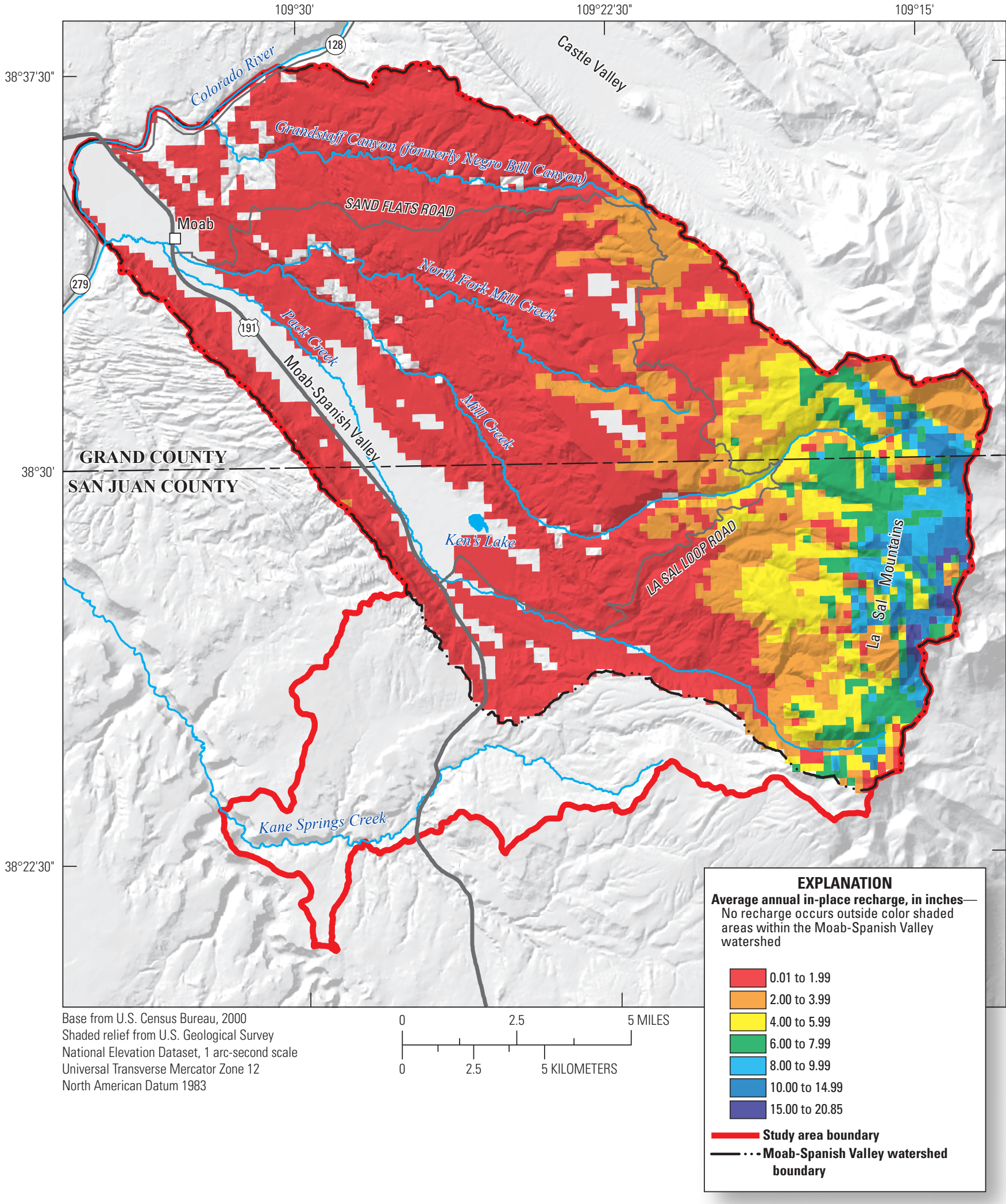

Figure 21. Distribution of average annual (1940-2012) in-place recharge estimated by the Basin Characterization Model in the MoabSpanish Valley watershed part of the Spanish Valley study area, Utah. 


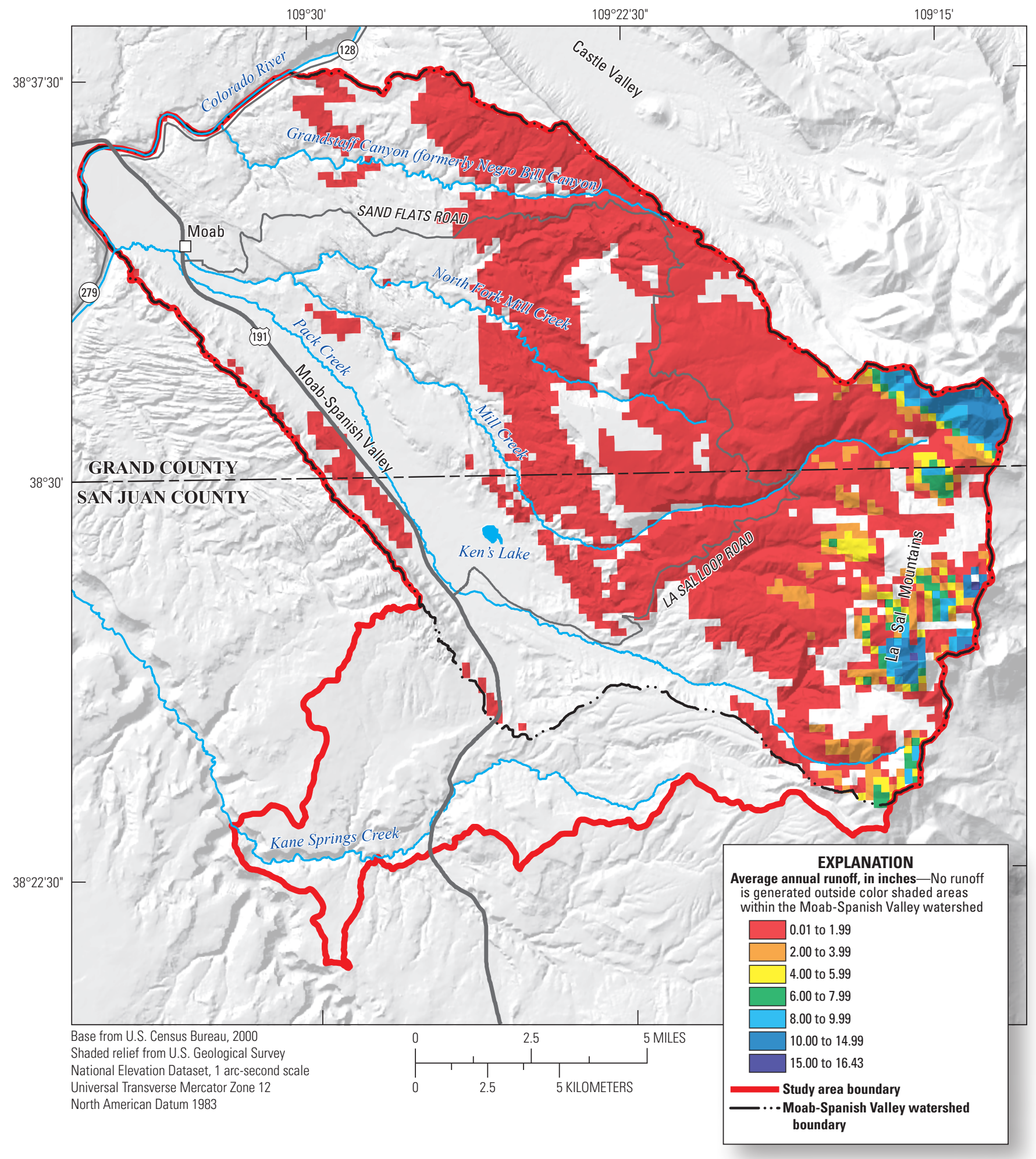

Figure 22. Distribution of average annual (1940-2012) runoff estimated by the Basin Characterization Model in the Moab-Spanish Valley watershed part of the Spanish Valley study area, Utah. 
It is likely that during spring and summer, some part of the groundwater discharging to streams is being intercepted and consumptively used (or evapotranspired; ETg) by vegetation along the stream channel. Because these measurements were made during the time of year when discharge to ETg is not occurring, the streams also were capturing groundwater that might otherwise have gone to ETg, so the stream measurements include the ETg component. Similarly, subsurface outflow to the lower part of the valley might provide some water for ETg in the wetlands, or subsurface flow to the Colorado River, or both. The subsurface outflow estimate, therefore, also included the ETg component for the wetland. Because the ETg estimates are inherently present in the discharge to streams and subsurface outflow estimates, independent estimates of ETg were not made for this study.

\section{Streams and Springs}

Stream measurements, and measurements of springs in lower Spanish Valley discharging directly to the Colorado River were made during the fall (November and December) of 2014, 2015, and 2016 to quantify observable groundwater discharge from the Moab-Spanish Valley watershed part of the study area during base flow conditions. There was no significant precipitation for several days prior to each measurement period, cool temperatures (below freezing each night) indicated that consumptive use by phreatophytic vegetation (ETg) was not significant, and there were no irrigation diversions or return flows (there is no surface-water irrigation from October 31 to March 15 of each year). It was assumed that all streamflow during these base flow periods was derived from groundwater discharge.

During this time of year, all springs in Spanish Valley either (1) discharge into Mill Creek and lower Pack Creek, (2) flow into the Matheson Wetlands and are assumed to eventually reach the Colorado River, or (3) are captured for culinary use. Although Moab City stores spring-water in two tanks that occasionally overflow into Mill Creek during the cooler months, these tanks were partially drained prior to streamflow measurements to ensure that no overflows occurred during the seepage studies. Spring discharge captured for culinary use is metered year round by Moab City and reported to the Utah Division of Water Rights. Discharge amounts for these springs are discussed in the section "Springs and Well Withdrawals for Culinary Use."

\section{Fall 2014}

Differential stream flow measurements were made on Mill Creek and Pack Creek during November and December 2014 to quantify groundwater discharge to streams in lower Spanish Valley. On December 1, 2014, streamflow at Mill Creek at Sheley Tunnel (MC-7, fig. 23) was $6.1 \pm 0.6$ cubic feet per second $\left(\mathrm{ft}^{3} / \mathrm{s}\right)$ and streamflow at Mill Creek below Sheley Tunnel (MC-8, fig. 23) was $6.6 \pm 0.7 \mathrm{ft}^{3} / \mathrm{s}$, indicating no diversions were occurring to
Ken's Lake (Mark Sovine, Grand Water and Sewer Service Agency, oral commun., December 1, 2014). On the same day, a measurement of $8.7 \pm 0.4 \mathrm{ft}^{3} / \mathrm{s}$ on Mill Creek at Powerhouse Dam (MC-21, fig. 23) where it first enters Spanish Valley, and a measurement of $8.6 \pm 0.4 \mathrm{ft}^{3} / \mathrm{s}$ just above the confluence with Pack Creek 2.6 mi downstream (MC-23, fig. 23) indicated no groundwater discharge to this reach of Mill Creek. The reach was walked and visually inspected to confirm no other surface-water inflows or diversions were occurring.

Differential stream measurements were also made along a 1-mi reach of Mill Creek from below the confluence with Pack Creek to Mill Creek at Matheson Wetlands. The reach was walked and visually inspected to confirm no other surface-water inflows or diversions were occurring. On November 12, 2014, identical replicate measurements of $7.2 \pm 0.4 \mathrm{ft}^{3} / \mathrm{s}$ were made on Mill Creek below Pack Creek (MC-24, fig. 23), and about $8.4 \mathrm{ft}^{3} / \mathrm{s}$ (replicate measurements of $8.3 \pm 0.4$ and $8.4 \pm 0.4 \mathrm{ft}^{3} / \mathrm{s}$ ) was measured at the pedestrian bridge at Matheson Wetlands (MC-25, fig. 23) indicating about $1.2 \mathrm{ft}^{3} / \mathrm{s}$ of groundwater discharge to the stream. These measurements were repeated on December 1, 2014, with $10.9 \pm 0.6 \mathrm{ft}^{3} / \mathrm{s}$ at Mill Creek below Pack Creek (MC24, fig. 23) and an average of $12.1 \pm 0.6 \mathrm{ft}^{3} / \mathrm{s}$ at Matheson Wetlands (replicate measurements of $12.4 \pm 0.6$ and $11.9 \pm 0.6 \mathrm{ft}^{3} / \mathrm{s}$; MC-25, fig. 23), again showing a gain of about $1.2 \mathrm{ft}^{3} / \mathrm{s}$.

About $1.7 \mathrm{ft}^{3} / \mathrm{s}$ of groundwater discharge to lower Pack Creek (either as direct gain to the stream or as nearstream springs flowing into the creek) was quantified by differential streamflow measurements during November and December 2014. The 5.9-mi reach was walked to confirm the absence of surface-water diversions; 11 near-stream springs were observed to flow into Pack Creek. Flow in the creek was observed to begin in the stream channel just across from the intersection of East Bench Road and South Creekside Lane at $38^{\circ} 31^{\prime} 40.7^{\prime \prime} \mathrm{N}$ and $109^{\circ} 29^{\prime}$ '2.1' W (PC-0, fig. 23). The streambed was dry above that location, indicating that all flow in Pack Creek in November and December of 2014 was groundwater discharge. During November 18-21, 2014, streamflow measurements on Pack Creek were made at Shumway Lane (replicate measurements of $1.4 \pm 0.1$ and $1.4 \pm 0.1 \mathrm{ft}^{3} / \mathrm{s}$; PC-1, fig. 23), at Pack Creek Campground (replicate measurements of $1.6 \pm 0.1$ and $1.6 \pm 0.1 \mathrm{ft}^{3} / \mathrm{s}$; PC-2, fig. 23), and just above the confluence with Mill Creek (replicate measurements of $1.8 \pm 0.1$ and $1.8 \pm 0.1 \mathrm{ft}^{3} / \mathrm{s}$; PC-3, fig. 23). On December 1, 2014, the same section was flowing, with $1.7 \pm 0.1 \mathrm{ft}^{3} / \mathrm{s}$ (identical replicate measurements) just above the confluence with Mill Creek. The total groundwater discharge to Mill Creek was assumed to be the $12.1 \mathrm{ft}^{3} / \mathrm{s}$ measured at MC-25 (average of replicate measurements).

Streamflow in the other streams flowing directly to the Colorado River-streams in Negro Bill and Ice Box Canyons (NB and IB, fig. 23)—was measured on November 21, 2014. Replicate streamflow measurements in the stream from Negro Bill Canyon were $1.8 \pm 0.1 \mathrm{ft}^{3} / \mathrm{s}$ and $1.7 \pm 0.1 \mathrm{ft}^{3} / \mathrm{s}$; $0.02 \pm 0.002 \mathrm{ft}^{3} / \mathrm{s}$ was measured in the stream from Ice Box Canyon. 


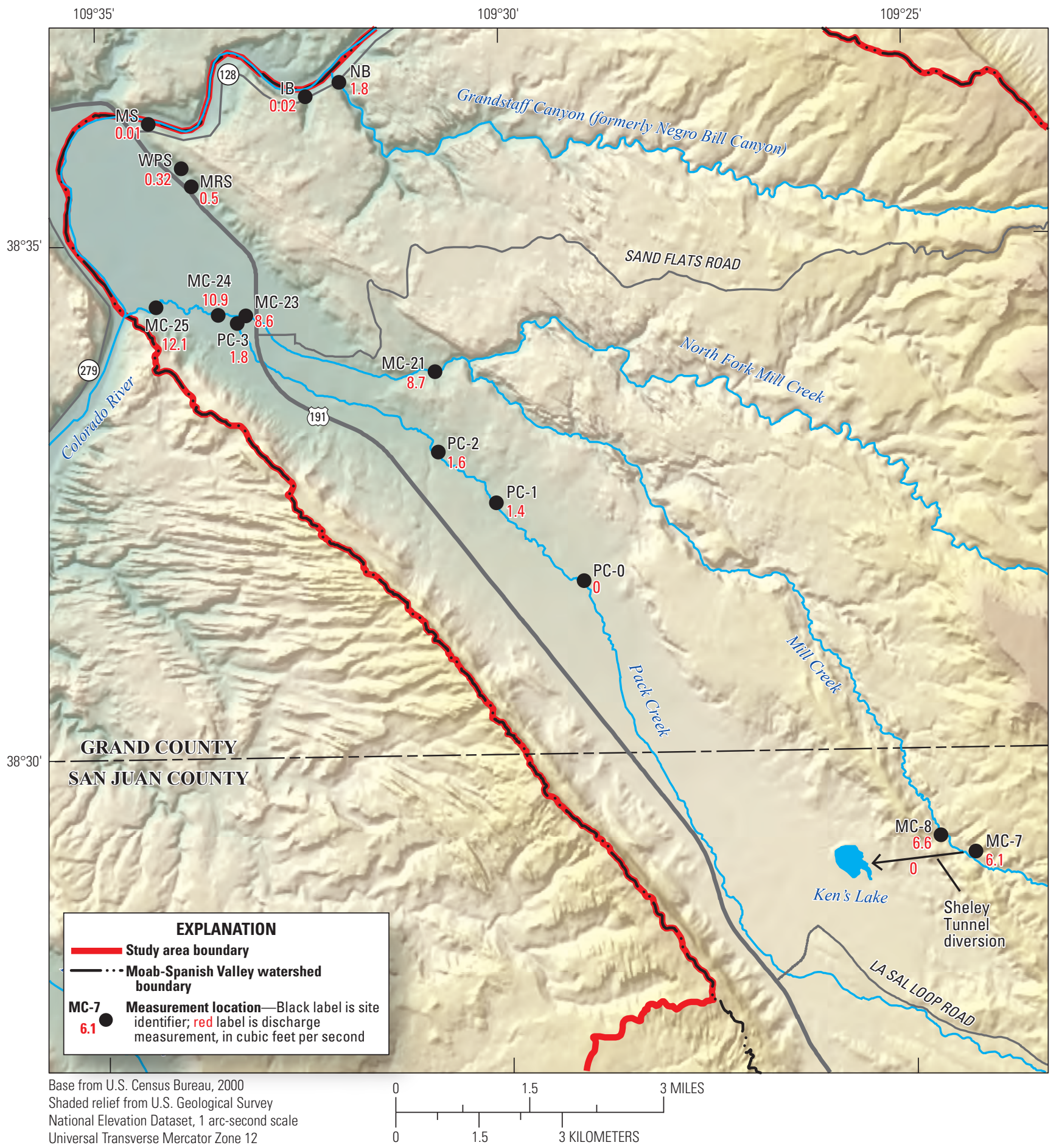

Universal Transverse Mercator Zone 12

North American Datum 1983

Figure 23. Location of groundwater and stream discharge measurements made during fall 2014 in the Spanish Valley study area, Utah. 
Measurements of springs discharging directly to the Colorado River totaled about $0.8 \mathrm{ft}^{3} / \mathrm{s}$. These included the combination of discharge from site MRS $\left(0.5 \pm 0.1 \mathrm{ft}^{3} / \mathrm{s}\right.$ on November 21, 2014; fig. 23), site WPS $\left(0.32 \pm 0.03 \mathrm{ft}^{3} / \mathrm{s}\right.$ on April 2, 2015; fig. 23), and site MS $\left(0.01 \pm 0.001 \mathrm{ft}^{3} / \mathrm{s}\right.$ on November 19, 2014; fig. 23). Site WPS could not be accessed during fall 2014, but it was assumed that discharge from this spring is relatively constant with time.

Total measurable discharge from the Spanish Valley groundwater system during November 12-December 1, 2014, was estimated to be about $14.7 \mathrm{ft}^{3} / \mathrm{s}(10,600 \mathrm{acre}-\mathrm{ft} / \mathrm{yr})$. This included flow from lower Mill Creek into the Colorado River $\left(12.1 \mathrm{ft}^{3} / \mathrm{s}\right)$, springs in lower Spanish Valley flowing directly to the Colorado River $\left(0.8 \mathrm{ft}^{3} / \mathrm{s}\right.$ ), and other streams (Negro Bill and Ice Box Canyons) flowing directly to the Colorado River $\left(1.8 \mathrm{ft}^{3} / \mathrm{s}\right)$.

\section{Fall 2015}

Differential stream flow measurements were again made on Mill Creek and lower Pack Creek during November 2015. Streamflow at Mill Creek below Sheley Tunnel (MC-8, fig. 24) was relatively steady during November 10-19, 2015, generally varying from 3 to $4 \mathrm{ft}^{3} / \mathrm{s}$. Although there was an increase in streamflow at Mill Creek at Sheley Tunnel (MC-7, fig. 24) above the diversion to Ken's Lake to above $8 \mathrm{ft}^{3} / \mathrm{s}$ from November 10-15, 2015, from a small precipitation event, streamflow on Mill Creek below Sheley Tunnel was held relatively steady by diversions to Ken's Lake. Also, pressure transducers installed to measure stream stage along lower Mill Creek only showed relatively small changes during the measurement period. On November 17, 2015, measured streamflow at Mill Creek at Sheley Tunnel (MC-7, fig. 24) and below the Sheley Tunnel (MC-8, fig. 24) was $7.7 \pm 0.4 \mathrm{ft}^{3} / \mathrm{s}$ and $3.2 \pm 0.2 \mathrm{ft}^{3} / \mathrm{s}$, respectively, indicating a diversion of $4.5 \mathrm{ft}^{3} / \mathrm{s}$ to Ken's Lake (confirmed by independent diversion measurements by Grand Water and Sewer Service Agency [Mark Sovine, written commun., November 2015]). On November 18, 2015, $2.55 \pm 0.2 \mathrm{ft}^{3} / \mathrm{s}$ was measured on Mill Creek above Spring Canyon (MC-15; fig. 24), indicating $0.5 \mathrm{ft}^{3} / \mathrm{s}$ of stream loss as groundwater recharge between MC-8 and MC-15. Further downstream, $3.0 \pm 0.3 \mathrm{ft}^{3} / \mathrm{s}$ was measured on Mill Creek below Spring Canyon at MC-16 (consistent with the $0.3 \mathrm{ft}^{3} / \mathrm{s}$ measured entering Mill Creek from Spring Canyon at MCT-1; fig. 24) and $3.6 \pm 0.3 \mathrm{ft}^{3} / \mathrm{s}$ was measured on Mill Creek at MC-19 (fig. 24) above the confluence with North Fork, indicating a stream gain (groundwater discharge) of $0.6 \mathrm{ft}^{3} / \mathrm{s}$ between $\mathrm{MC}-16$ and MC-19. On November 17, $2015,7.7 \pm 0.4 \mathrm{ft}^{3} / \mathrm{s}$ was measured at MC-21 (consistent with $4.0 \mathrm{ft}^{3} / \mathrm{s}$ entering from North Fork at NF-13; fig. 24), $7.6 \pm 0.6 \mathrm{ft}^{3} / \mathrm{s}$ was measured at MC-23 (fig. 24), $9.3 \pm 0.5 \mathrm{ft}^{3} / \mathrm{s}$ was measured at MC-24 (consistent with $1.8 \pm 0.1 \mathrm{ft}^{3} / \mathrm{s}$ entering from Pack Creek measured at PC-3; fig. 24), and $9.0 \pm 0.4 \mathrm{ft}^{3} / \mathrm{s}$ was measured at MC-25 (fig. 24). Thus, the section from MC-24 to MC-25 was not a gaining reach in
November 2015 (in contrast to the $1.2 \mathrm{ft}^{3} / \mathrm{s}$ gain measured in 2014). Although there was a small decline in streamflow $\left(0.3 \mathrm{ft}^{3} / \mathrm{s}\right)$ between MC-24 and MC-25, the total groundwater discharge to Mill Creek was assumed to be the $9.3 \mathrm{ft}^{3} / \mathrm{s}$ measured at MC-24.

Streamflow measurements made on November 19, 2015, in the other streams flowing directly to the Colorado River were $1.49 \pm 0.12 \mathrm{ft}^{3} / \mathrm{s}$ in the stream from Negro Bill Canyon and $0.02 \pm 0.001 \mathrm{ft}^{3} / \mathrm{s}$ in the stream from Ice Box Canyon (NB and IB, fig. 24). Measurements of springs discharging directly to the Colorado River totaled about $0.9 \mathrm{ft}^{3} / \mathrm{s}$. This includes the combination of discharge from site MRS $\left(0.70 \pm 0.06 \mathrm{ft}^{3} / \mathrm{s}\right.$ on November 16, 2015, fig. 24) and site WPS $\left(0.19 \pm 0.02 \mathrm{ft}^{3} / \mathrm{s}\right.$ on November 17, 2015, fig. 24).

Total measurable discharge from the Spanish Valley groundwater system during November 17-19, 2015, was estimated to be about $16.2 \mathrm{ft}^{3} / \mathrm{s}(11,700$ acre-ft/yr). This included the diversion to Ken's Lake $\left(4.5 \mathrm{ft}^{3} / \mathrm{s}\right)$, flow from lower Mill Creek into the Colorado River $\left(9.3 \mathrm{ft}^{3} / \mathrm{s}\right)$, springs in lower Spanish Valley flowing directly to the Colorado River $\left(0.9 \mathrm{ft}^{3} / \mathrm{s}\right)$, and other streams (Negro Bill Wash and Ice Box Canyon) flowing directly to the Colorado River $\left(1.5 \mathrm{ft}^{3} / \mathrm{s}\right)$.

\section{Fall 2016}

Differential stream-flow measurements were again made on Mill Creek and lower Pack Creek during November 7-9, 2016. Streamflow at Sheley Tunnel above the diversion to Ken's Lake (MC-7, fig. 25) averaged $7.6 \mathrm{ft}^{3} / \mathrm{s}$, with small fluctuations between 7.5 and $7.8 \mathrm{ft}^{3} / \mathrm{s}$. Streamflow on Mill Creek below Sheley Tunnel (MC-8, fig. 25) was relatively steady at about $3.6 \mathrm{ft}^{3} / \mathrm{s}$, declining slightly from 3.7 to $3.4 \mathrm{ft}^{3} / \mathrm{s}$ during that period, indicating a diversion of about $4 \mathrm{ft}^{3} / \mathrm{s}$ to Ken's Lake.

On November 9, 2016, $2.94 \pm 0.15 \mathrm{ft}^{3} / \mathrm{s}$ was measured on Mill Creek near the Moab Area Water Partnership (MAWP) monitoring site (MC-MAWP, fig. 25), indicating about $0.6 \mathrm{ft}^{3} / \mathrm{s}$ loss to the Navajo Sandstone along the reach below the Sheley Tunnel to this location. Further downstream, about $0.5 \mathrm{ft}^{3} / \mathrm{s}$ of loss occurred along Mill Creek between Hidden Valley and Mill Creek based on measurements at MC-14 Modified and MC-15 of $2.77 \pm 0.22 \mathrm{ft}^{3} / \mathrm{s}$ and $2.30 \pm 0.18 \mathrm{ft}^{3} / \mathrm{s}$, respectively (fig. 25). At MC-21, $6.01 \pm 0.30 \mathrm{ft}^{3} / \mathrm{s}$ was measured, including $3.37 \pm 0.17 \mathrm{ft}^{3} / \mathrm{s}$ contribution from North Fork (NF-13; fig. 25). About $0.3 \mathrm{ft}^{3} / \mathrm{s}$ of loss occurred along Mill Creek as it first entered Spanish Valley based on a measurement of $5.66 \pm 0.45 \mathrm{ft}^{3} / \mathrm{s}$ at MC-23, just above the confluence with Pack Creek (fig. 25). With Pack Creek contributing $1.39 \pm 0.07 \mathrm{ft}^{3} / \mathrm{s}$ (PC-3; fig. 25), total flow below the confluence at MC-24 was $7.04 \pm 0.35 \mathrm{ft}^{3} / \mathrm{s}$ (fig. 25). A slight gain of $0.3 \mathrm{ft}^{3} / \mathrm{s}$ occurred between the Pack Creek confluence and MC-25 (7.38 $\pm 0.37 \mathrm{ft}^{3} / \mathrm{s}$; fig. 25). The total groundwater discharge to Mill Creek was assumed to be the $7.4 \mathrm{ft}^{3} / \mathrm{s}$ measured at MC-25. 


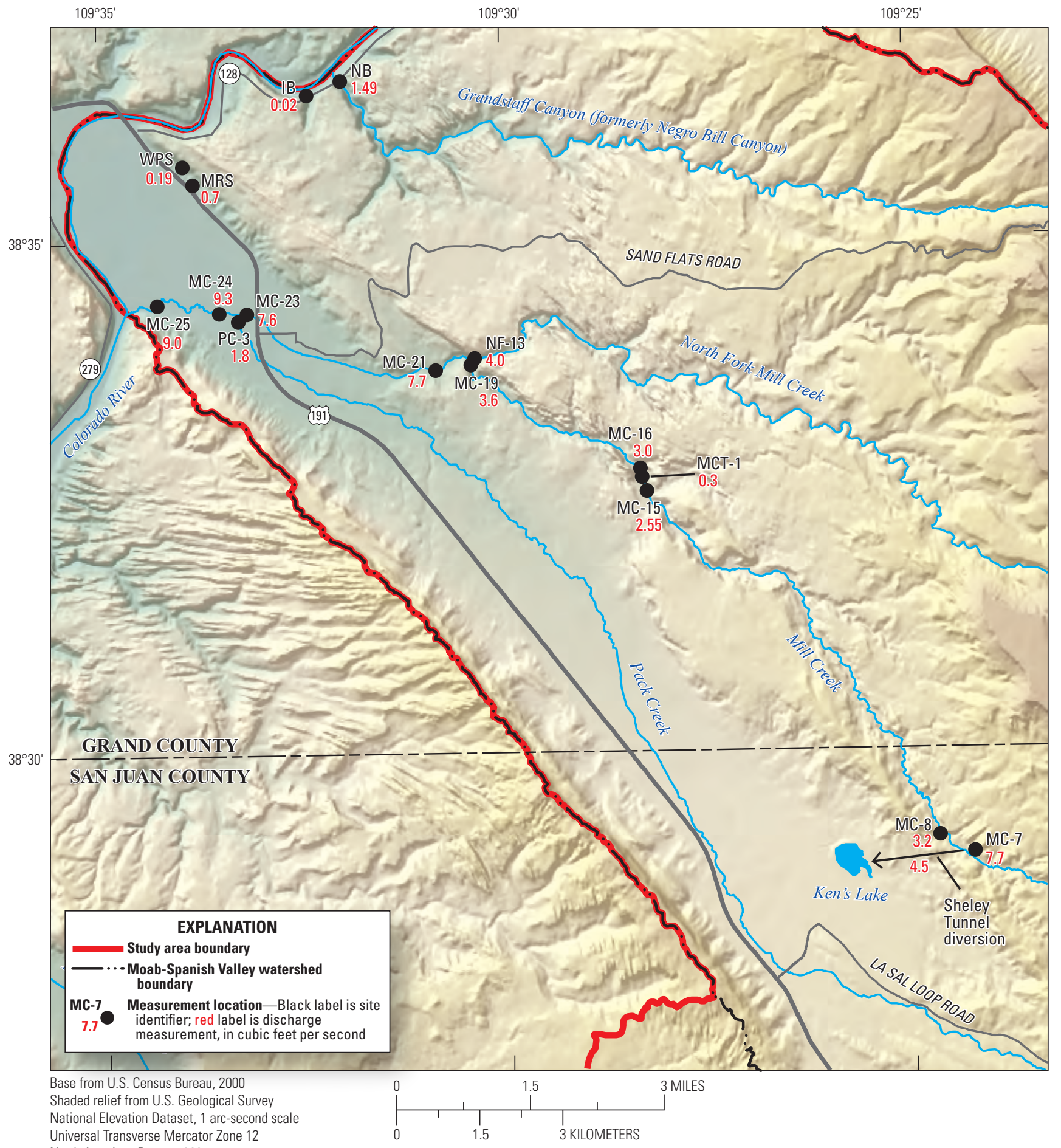

Universal Transverse Mercator Zone 12

Figure 24. Location of stream and spring discharge measurements made during fall 2015 in the Spanish Valley study area, Utah. 


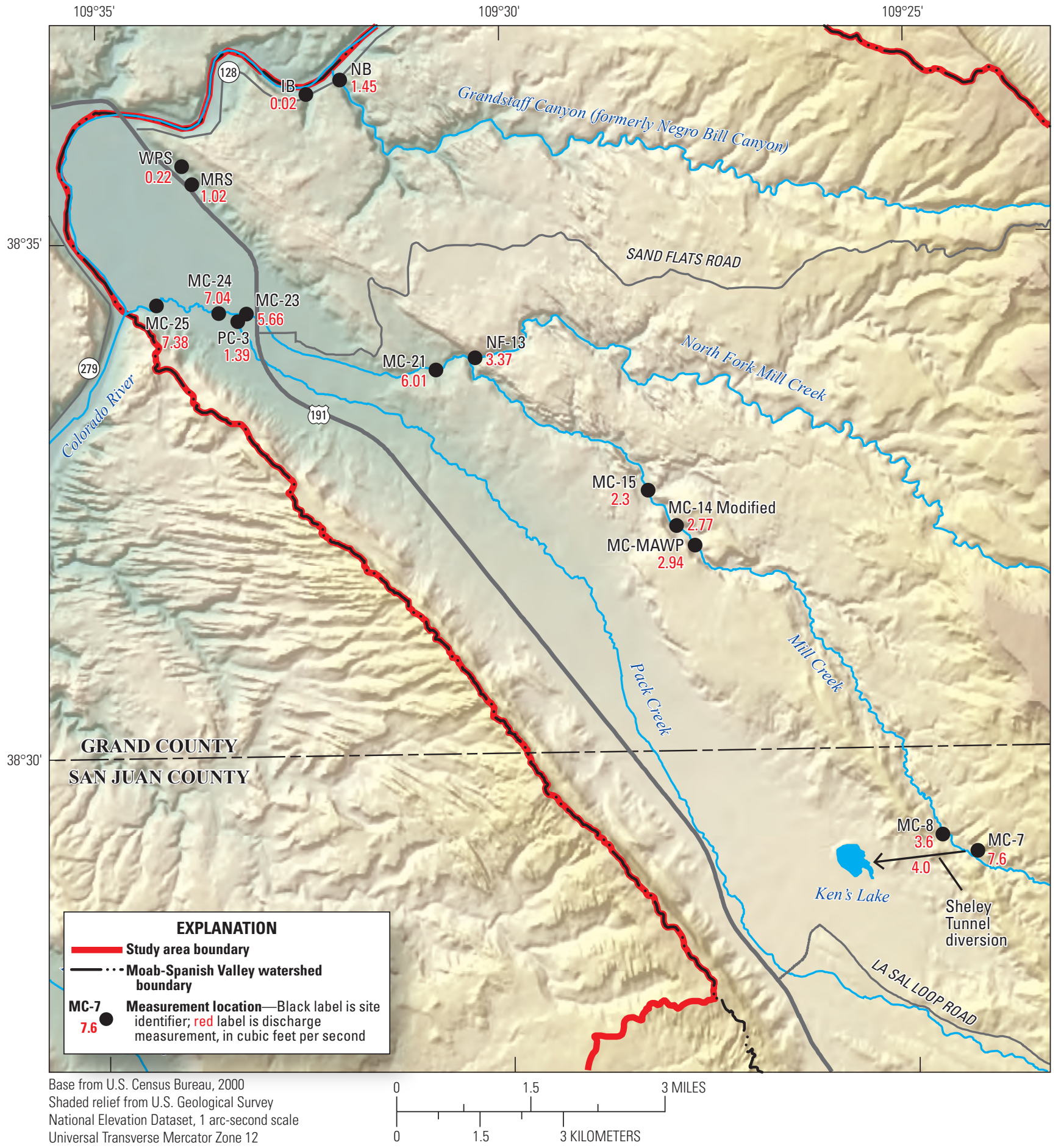

Universal Transverse Mercator Zone 12

Figure 25. Location of stream and spring discharge measurements made during fall 2016 in the Spanish Valley study area, Utah. 
Regarding other streams flowing directly to the Colorado River, discharge measurements on November 9, 2016, were $1.45 \pm 0.12 \mathrm{ft}^{3} / \mathrm{s}$ in the stream from Negro Bill Canyon and $0.02 \pm 0.001 \mathrm{ft}^{3} / \mathrm{s}$ in the stream from Ice Box Canyon (NB and IB, fig. 25). Measurements of springs flowing directly to the Colorado River included site MRS $\left(1.02 \pm 0.10 \mathrm{ft}^{3} / \mathrm{s}\right)$ and WPS $\left(0.22 \pm 0.01 \mathrm{ft}^{3} / \mathrm{s}\right)$, both measured on November 9 , 2016 (fig. 25).

Total measurable discharge from the Spanish Valley groundwater system during November 7-9, 2016, was estimated to be about $14.1 \mathrm{ft}^{3} / \mathrm{s}(10,200 \mathrm{acre}-\mathrm{ft} / \mathrm{yr})$. This included the diversion to Ken's Lake $\left(4.0 \mathrm{ft}^{3} / \mathrm{s}\right)$, flow from lower Mill Creek into the Colorado River $\left(7.4 \mathrm{ft}^{3} / \mathrm{s}\right)$, springs in lower Spanish Valley flowing directly to the Colorado River $\left(1.2 \mathrm{ft}^{3} / \mathrm{s}\right.$ ), and other streams (Negro Bill and Ice Box Canyons) flowing directly to the Colorado River $\left(1.5 \mathrm{ft}^{3} / \mathrm{s}\right)$.

\section{Summary of Base-Flow Groundwater Discharge Measurements}

Three years (2014-16) of measured base-flow groundwater discharge from the study area based on streamflow and discharge measurements from springs in lower Spanish Valley are summarized in table 12 and figure 26. This does not include any groundwater moving directly to the Colorado River as subsurface outflow. Total measured groundwater discharge for these 3 years of base-flow measurements ranged from 14.1 to $16.2 \mathrm{ft}^{3} / \mathrm{s}(10,200$ to $11,700 \mathrm{acre}-\mathrm{ft} / \mathrm{yr}$, tables 11 and 12).

\section{Springs and Well Withdrawals for Culinary Use}

Sources of culinary water managed by Moab City and GWSSA include springs and wells. Diversions from the springs and withdrawals from the wells are reported to the Utah Division of Water Rights water use website (available at https://waterrights.utah.gov/wateruse/WaterUseList.asp, accessed May 21, 2019). Total spring diversions and well withdrawals for culinary use reported by Moab City were 1,528, 2,057, and 2,251 acre-ft for 2014, 2015, and 2016, respectively. Total well withdrawals for culinary use reported by GWSSA were 908, 910, and 1,010 acre-ft for 2014, 2015, and 2016, respectively. The total annual amount of groundwater discharge to springs and well withdrawals for culinary use from 2014-16 ranged from 2,400 to 3,300 acre-ft (table 11 and fig. 26).

\section{Well Withdrawals for Irrigation}

Well withdrawals used for irrigation were quantified for the study area using data reported to the Utah Division of Water Rights (available at https://www.waterrights.utah.gov/ wateruse/WaterUseList.asp accessed May 21, 2019). This includes data from wells managed by GWSSA and Moab City. Discharge from private irrigators in the study area was not quantified because (1) private irrigators are not required
Table 12. Summary of total measured base-flow groundwater discharge (2014-16) in the Spanish Valley study area, Utah.

[Abbreviations: $\mathrm{ft}^{3} / \mathrm{s}$, cubic feet per second; acre-ft/yr, acre-feet per year; -, no data]

\begin{tabular}{|c|c|c|c|}
\hline \multirow[t]{2}{*}{ Site(s) } & \multicolumn{3}{|c|}{$\begin{array}{l}\text { Total measured base-flow } \\
\text { groundwater discharge } \\
\left(\mathrm{ft}^{3} / \mathrm{s}\right)\end{array}$} \\
\hline & 2014 & 2015 & 2016 \\
\hline Ken's Lake diversion & - & 4.5 & 4.0 \\
\hline Lower Mill Creek & 12.1 & 9.3 & 7.4 \\
\hline Springs in lower Spanish Valley & 0.8 & 0.9 & 1.2 \\
\hline Negro Bill and Ice Box Canyons & 1.8 & 1.5 & 1.5 \\
\hline Total $\left(\mathrm{ft}^{3} / \mathrm{s}\right)$ & 14.7 & 16.2 & 14.1 \\
\hline Total (acre-ft/yr), rounded & 10,600 & 11,700 & 10,200 \\
\hline
\end{tabular}

to meter or report their water use, and (2) a combination of both surface water and groundwater are used to irrigate crops within the study area.

Annual withdrawals for 2014-16 from the GWSSA and Moab City managed wells are summarized in table 13. In 2014, well withdrawals for irrigation from the GWSSA wells were 140 acre- $\mathrm{ft}$, and well withdrawals for irrigation from the Moab City wells were 110 acre-ft. In 2015, well withdrawals from the GWSSA wells were 60 acre-ft, and well withdrawals from the Moab City wells were 20 acre-ft. In 2016, well withdrawals from the GWSSA wells were 72 acre-ft, and well withdrawals from the Moab City well were 17 acre-ft. The total annual amount of groundwater discharge to well withdrawals for irrigation from 2014-16 ranged from 80 to 250 acre-ft (table 11 and fig. 26).

\section{Discharge as Subsurface Outflow to the Colorado River}

The Colorado River is the terminal groundwater discharge point for water within the Moab-Spanish Valley watershed, however, it is difficult to quantify the amount of groundwater discharging to the river. A traditional seepage study within the Colorado River to quantify the groundwater discharge does not work for the study area because (1) the river has a complex geometry, which can introduce large uncertainties in seepage measurements; (2) flows in the river are large and, therefore, uncertainties in the flow measurements would be large; the amount of groundwater discharging to the river would be far less than the uncertainty of the flow measurements (by several orders of magnitude); and (3) a seepage study would not be able to differentiate what is discharging into the river from the Moab-Spanish Valley watershed, and what is discharging from the area northwest of the river. Because of these limitations, other indirect methods of estimating groundwater discharge to the Colorado River using hydraulic gradient and aquifer property data were used in this study and previous studies. 


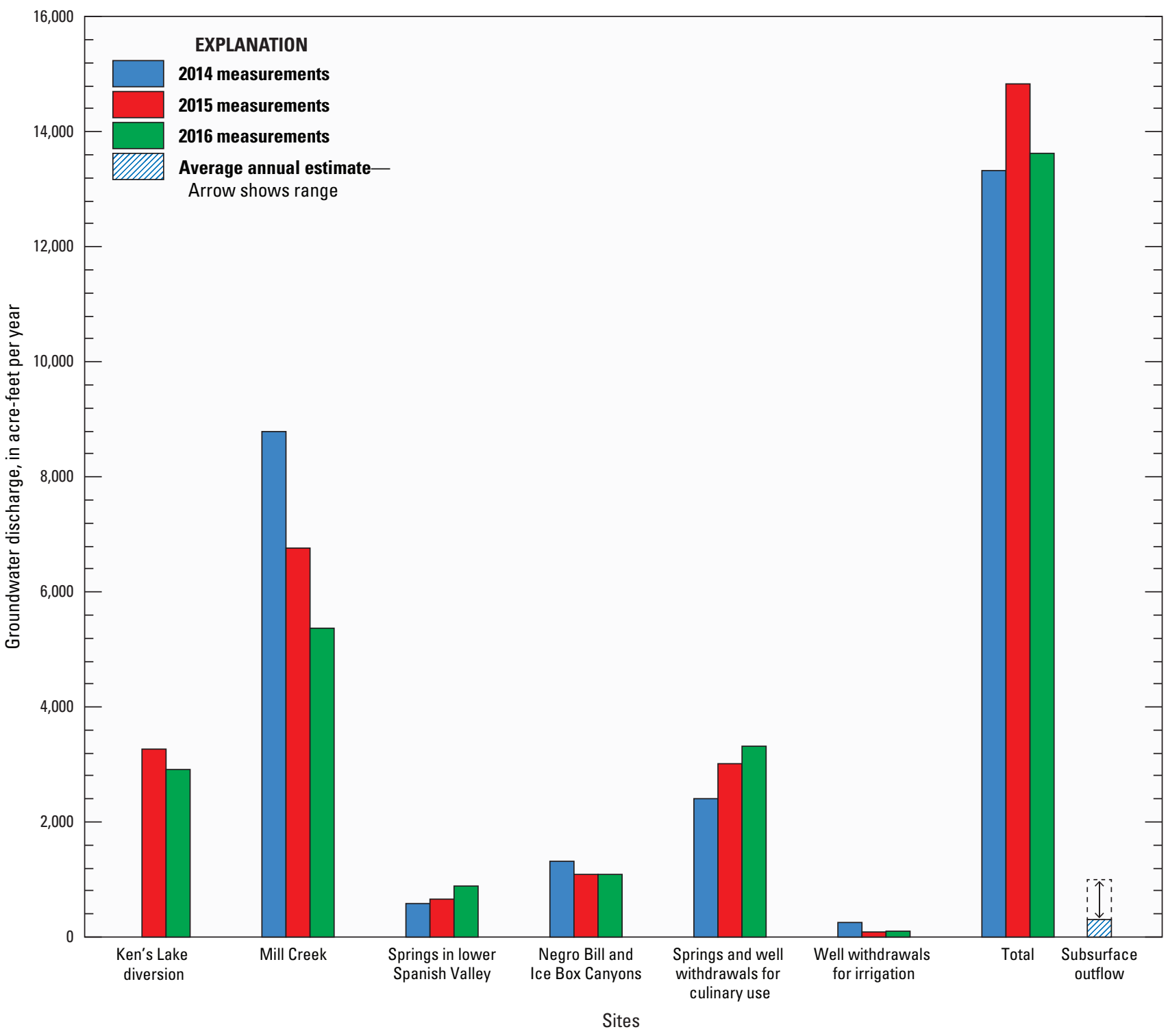

Figure 26. Groundwater discharge in the Spanish Valley study area, Utah.

Table 13. Summary of well withdrawals for irrigated crops in the Spanish Valley study area, Utah.

[All values in acre-feet. Data from https://www.waterrights.utah.gov/wateruse/ WaterUseList.asp, accessed May 21, 2019. Abbreviation: GWSSA, Grand Water and Sewer Service Agency]

\begin{tabular}{lccc}
\hline & $\mathbf{2 0 1 4}$ & $\mathbf{2 0 1 5}$ & $\mathbf{2 0 1 6}$ \\
\hline GWSSA irrigation withdrawals & 140 & 60 & 72 \\
Moab City irrigation withdrawals & 110 & 20 & 17 \\
\hline
\end{tabular}


Groundwater discharge from the GCGA to the Colorado River could not be estimated in the current study even by indirect methods because there is a lack of water-level and aquifer property data near the river needed to make these calculations. It is likely, however, that most of the discharge from the GCGA is occurring to other streams (such as Mill Creek) and springs, and that what is left to discharge to the Colorado River is assumed to be a negligible amount.

Groundwater discharge from the VFA to the Colorado River was estimated in the current study. Previous estimates of groundwater discharge from the VFA to the Colorado River at the lower end of Moab-Spanish Valley ranged between 110 and 8,000 acre-ft/yr (Sumsion, 1971; Gardner, 2004). The large difference between these estimates is mainly because of the differences of the saturated thicknesses of the VFA used in the Darcy-flux calculations of these estimates. Additionally, the transmissivity of the VFA was largely unknown in the Matheson Wetlands Preserve and near the Colorado River. To better constrain the estimate of groundwater discharge through subsurface outflow to the Colorado River from the VFA, a detailed analysis in the wetland and near the river, including geophysical surveys and new well installations, was conducted during this study and is discussed in the following sections.

\section{Geophysical Characterization of Shallow Groundwater Salinity}

A geophysical survey measuring electrical conductivity was conducted in the Matheson Wetlands during March 2015 to differentiate areas of potentially fresh shallow (less than $60 \mathrm{ft}$ ) groundwater discharging to the Colorado River and surrounding areas of shallow highly saline groundwater (brine; fig. 27). The results of this survey were used to help site several new observation wells installed specifically for evaluating subsurface outflow of shallow fresh groundwater to the Colorado River.

Electrical conductivity of earth materials is affected by various factors including mineralogy, porosity, water saturation, and fluid salinity. The presence of shallow highly saline groundwater beneath the wetland and adjacent to the Colorado River was expected to generate a bulk conductivity signature that is a factor of 10 or greater than fresh groundwater, making it an ideal target for electrically based geophysical methods. For this investigation, a handcarried frequency-domain electromagnetic (FDEM) tool was used to characterize the upper (approximate) $30 \mathrm{ft}$ of earth material and surface water. FDEM instruments measure subsurface apparent electrical conductivity utilizing timevarying electromagnetic fields to induce subsurface electrical eddy currents (Ward and Hohmann, 1988). This non-invasive approach enables the rapid mapping (walking speed) of depthspecific subsurface bulk conductivity where lower frequencies tend to evaluate deeper material. FDEM has been widely used in groundwater studies (for example, Johnson and others,
2002), including the mapping of landscape-scale groundwater/ surface water exchanges in the presence of shallow brine (for example, Ong and others, 2010).

The specific FDEM instrument used for this study is the GEM-2 (manufactured by Geophex, Inc., Raleigh, North Carolina), and was operated over seven frequencies ranging from 1,530 to 47,970 hertz (Hz). Prior to data collection, the instrument was powered on and set to transmit for approximately 15 minutes to allow the coils and internal electronics to equilibrate to the operating temperature. After system warm-up, a baseline reference station was occupied for at least 2 minutes with the instrument actively transmitting and receiving at the start and end of each field day. FDEM data were collected by walking along the ground surface with the unit held at waist level on land, and strapped directly to a plastic kayak on the river, all in vertical-dipole mode. Occupying the drift reference station before and after each survey permitted removal of FDEM instrument drift during data processing with the PrepEM software. A two-dimensional cross section of electrical conductivity was modeled for a line (A-A', figs. 27 and 28) along the road that parallels the river on the western edge of the wetland using the inversion software EM1DFM (Farquharson and others, 2003).

Directly coupled vertical electrical soundings (VES) also were collected at four locations for a deeper (approximately $25 \mathrm{~m}$ ) evaluation of subsurface conductivity to augment the FDEM data (fig. 27). Each VES measurement integrates approximately 11 soundings with 4 electrodes driven into the soil and spaced from 1 to $40 \mathrm{~m}$ apart in a linear Wenner array. Data were collected manually with a SuperSting electrical resistivity meter (Advanced Geosciences, Inc., Austin, Texas). The VES soundings were acquired at sites thought to be underlain by fresh, brackish, and (or) saline groundwater as determined from preliminary inspection of GEM-2 field data. The VES data were inverted to obtain "smooth" (11-layer) one-dimensional geoelectric models using Res1D1 (version 1.00.09, Constable and others, 1987; fig. 29).

The mean apparent conductivity across all FDEM frequencies indicated shallow brine (warmer colors, fig. 27) across much of the central and northern river bank and in the near-river wetland area. Data were negatively impacted (showing decreased mean apparent conductivity) by a thick unsaturated zone beneath a high dry berm near the northern end of line $\mathrm{A}-\mathrm{A}^{\prime}$, and by deep river water near shore during waterborne data collection along line B-B' (fig. 27). These data are symbolized as "excluded" on figures 27 and 28 . The waterborne and land-surface FDEM data indicate a zone of likely fresh shallow groundwater (cooler colors, fig. 27) along the Colorado River within approximately the southern onethird of the wetland, toward the outlet of Mill Creek.

Inverted conductivity data along line $\mathrm{A}-\mathrm{A}^{\prime}$ show a strong indication of brine within about $10 \mathrm{ft}$ of the ground surface (at the water table) for essentially the entirety of the line except for the southern section around VES points 3 and 4 (fig. 28). 


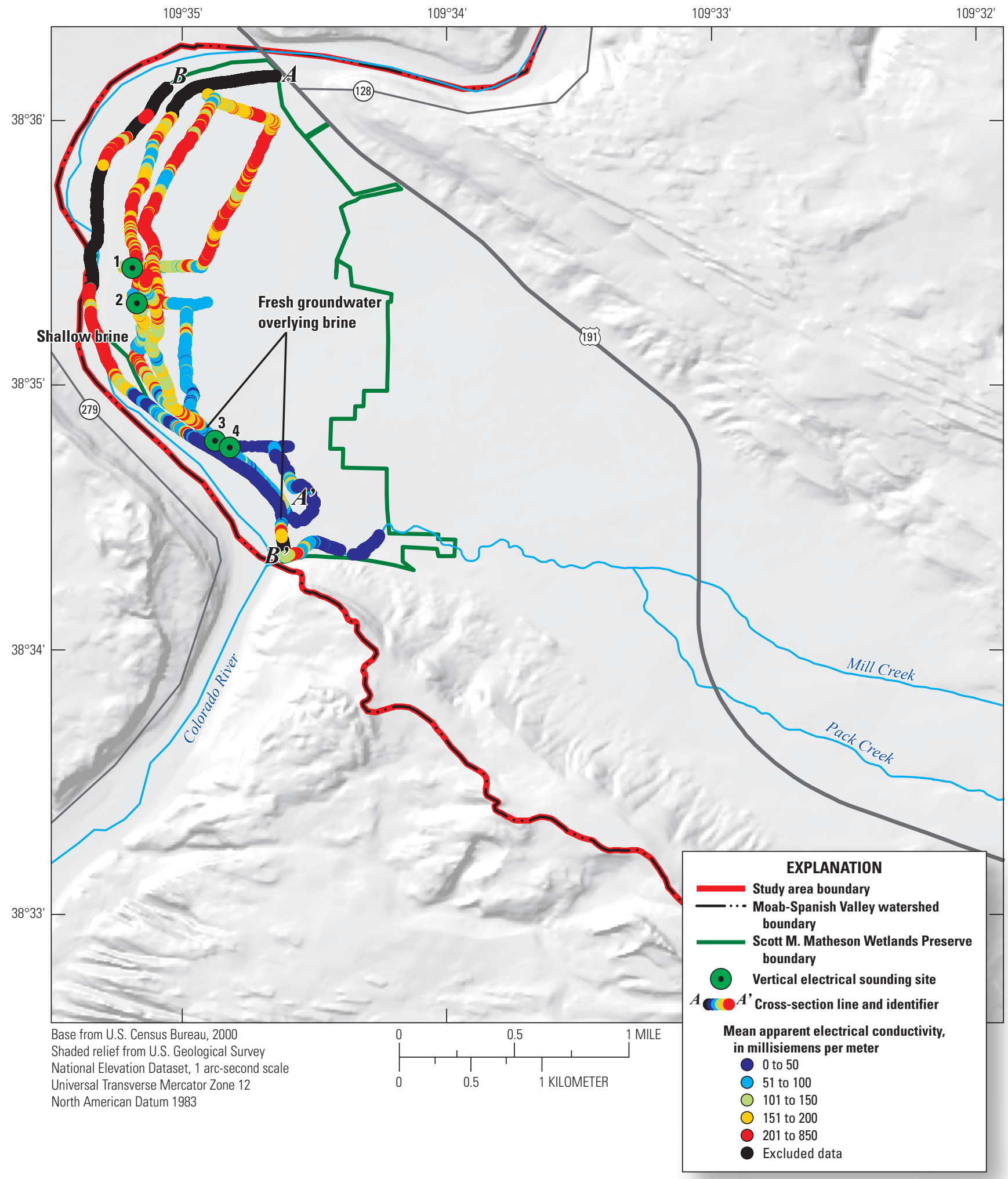

Figure 27. Mean apparent electrical conductivity obtained by frequency-domain electromagnetic survey and vertical electrical sounding points collected on and near the Colorado River in the Matheson Wetlands Preserve, Moab, Utah. 


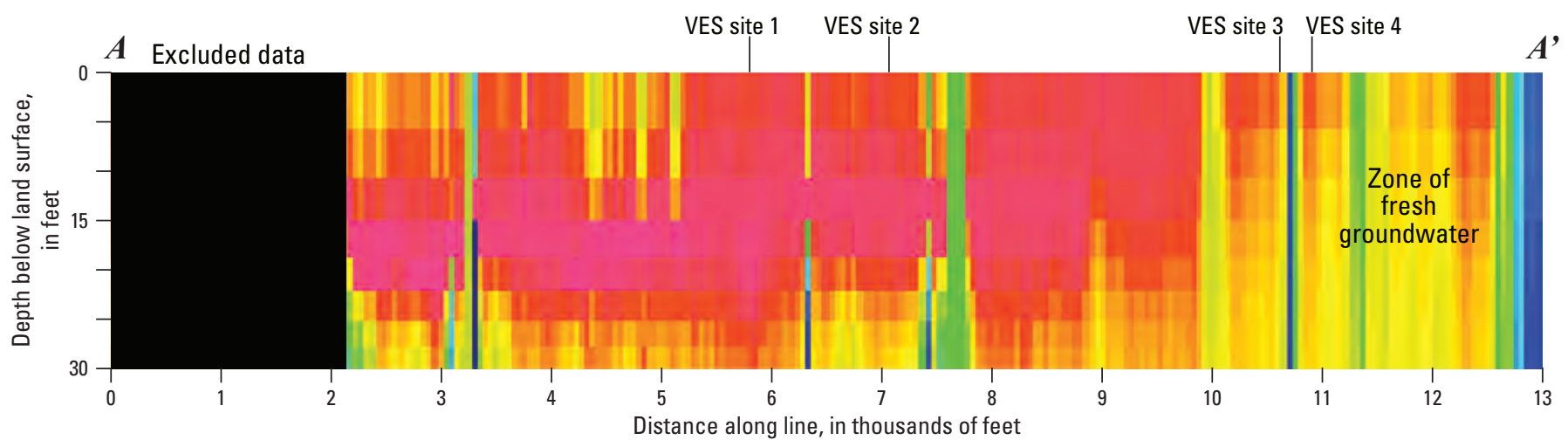

EXPLANATION

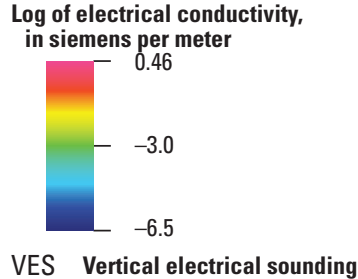

Figure 28. Log of electrical conductivity with depth and vertical sounding points along line A-A'. Warmer colors (pink and red) represent shallow brines, and cooler colors (yellow, green, and blue) represent the likely zone of fresh groundwater.

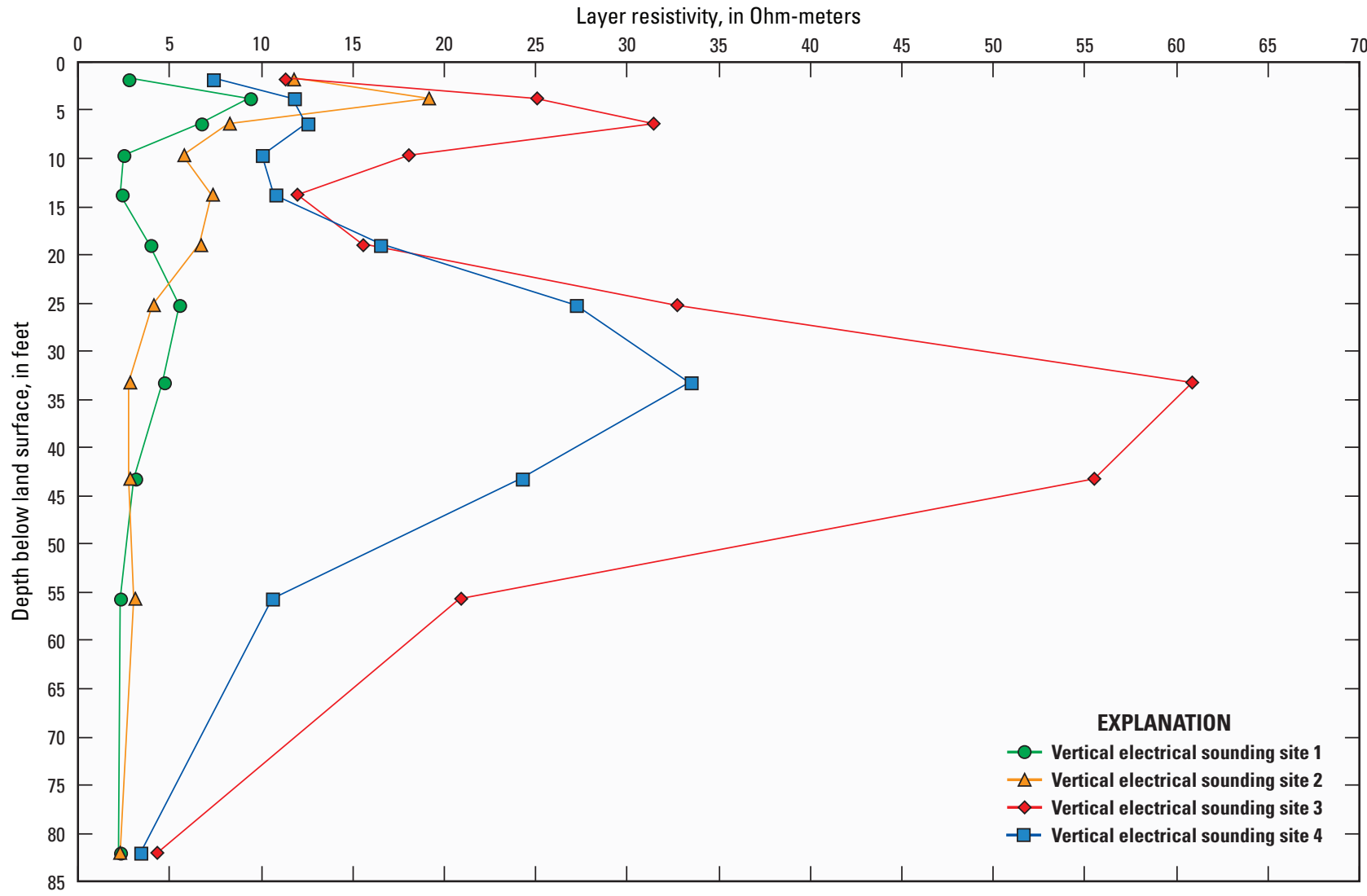

Figure 29. Results of modeled vertical electrical sounding data. The higher resistivity at sites 3 and 4 at approximately 5- to 60-feet depth compared to sites 1 and 2 indicates the presence of fresh groundwater near the Colorado River in the Matheson Wetlands Preserve, Moab, Utah. 
Geoelectrical models indicate all VES sounding locations are underlain by groundwater of elevated salinity, but the depth of this interface varies strongly between VES sites 1 and 2, and 3 and 4 (fig. 29). Saline groundwater extends to about $1 \mathrm{~m}(3.281 \mathrm{ft})$ below ground surface at VES sites 1 and 2, whereas a sequence of fresh groundwater as much as $55 \mathrm{ft}$ thick (between about 5 - $\mathrm{ft}$ and $60-\mathrm{ft}$ depth) overlies brackish groundwater at VES sites 3 and 4 . These results indicate that the only zone of fresher groundwater near the river is located through the area around VES sites 3 and 4, and southward toward Mill Creek.

\section{Drilling and Well Installation}

Results from all data collected during the geophysical survey led to siting the majority of new observation wells in the southern part of the wetland. Twelve wells were installed in the wetland, including eight single-completion (U12-U19) and two dual-completion (U20-U21 and U22-U23) wells (fig. 30). The wells were used for aquifer testing, geochemical sampling, and hydraulic head measurements. The wells were installed along a transect meant to approximate the trace through which a Darcy-flux would be calculated (fig. 30). Unfortunately, the central area between U16 and U19 was inaccessible with the drill rig due to the muddy nature of the wetland; however, the wells have good spatial coverage in the area near Mill Creek where the majority of fresh groundwater flow was thought to occur according to the geophysical characterization (fig. 27). The locations of the two well pairs (wells U20 and U21, and wells U22 and U23) were selected to verify the location and depth of the freshwater lens at its thickest point along the Colorado River, as indicated by the electrical resistivity survey (fig. 29).

Drilling and well installation was performed by RB\&G Engineering using a single-axle auger rig. The auger bit was 4 in. in outer diameter with a 1-in. flight, resulting in boreholes that have a diameter of approximately $6 \mathrm{in}$. Wells ranged in depth from 25 to $61 \mathrm{ft}$ (fig. 31). Each well was constructed with 2.5 -in. schedule 40 polyvinyl chloride (PVC) pipe with a 5-ft screened interval. Wells were completed with coarsegrained silica sand around the well screen, bentonite backfill, and $6 \mathrm{ft}$ of cement grout with either a steel or aluminum cap. Wells were developed using a Waterra (Mississauga, Ontario) Inertial Pump operated by a portable actuator until the water was visibly clear prior to aquifer testing with a Grundfos (Bjerringbro, Denmark) submersible pump.

The materials encountered during drilling were primarily sand and gravel (fig. 31). Although gravel did not typically rise to the surface while drilling (it was probably pushed into the sides of the borehole), it was known to be present by shaking and rattling of the drill rig. A split-spoon sample was taken during one such occurrence, and revealed pebbles with diameters up to 2 in. Wells were completed within highpermeability gravels wherever possible.

\section{Aquifer-Test Analysis}

Eleven aquifer tests were performed on the newly completed observation wells (nine single-well aquifer tests, including a repeat, and two dual-well aquifer tests). A Grundfos submersible pump was used to create drawdown, which was recorded every second on either a Hobo (Bourne, Massachusettes) or Troll (In-Situ, Fort Collins, Colorado) transducer. The 1-second data were later reduced to 1-minute data for analysis. Pumping rates were measured throughout the test using a calibrated 5-gallon bucket and stopwatch and ranged from approximately 0.3 to 5 gallons per minute (gal/min). The duration of pumping was approximately 3 hours, after which water levels were allowed to recover for at least 30 minutes or until they had returned to static level. For the dual aquifer tests at well pairs U20-U21, and U22-U23, the deeper wells of each pair (U20 and U22) were pumped while observations also were recorded in the shallower wells of each pair (U21 and U23).

Where possible, transmissivity was estimated using the Cooper-Jacob (1946) straight-line method for drawdown data and the Theis (1935) recovery method for recovery data. Additionally, transmissivity was estimated from specific capacity.

The Cooper-Jacob (1946) straight-line method is a graphical approach to evaluating aquifer properties from drawdown in a well or wells over time. From drawdown data, transmissivity was calculated as:

$$
T=\frac{2.3 Q}{4 \pi \Delta s}
$$

where

$T$ is the transmissivity, in $\mathrm{ft}^{2} / \mathrm{d}$;

$Q \quad$ is the pumping rate, in cubic feet per day $\left(\mathrm{ft}^{3} / \mathrm{d}\right)$; and

$\Delta s \quad$ is the change in drawdown, in $\mathrm{ft}$, corresponding to one-log cycle of time on a line fit to the late-time data on a semi-log plot of time against drawdown data.

Similarly, transmissivity was calculated from recovery data as:

$$
T=\frac{2.3 Q}{4 \pi \Delta s^{\prime}}
$$

where

$$
\begin{array}{cl}
T & \text { is the transmissivity, in } \mathrm{ft}^{2} / \mathrm{d} ; \\
Q & \text { is the pumping rate, in } \mathrm{ft}^{3} / \mathrm{d} \text {; and } \\
\Delta s^{\prime} & \text { is the change in recovery, in } \mathrm{ft} \text {, corresponding } \\
\text { to one-log cycle of time on a semi-log } \\
\text { plot of } t / t^{\prime} \text { against } \Delta s^{\prime}, \text { where } t \text { is the time } \\
\text { since pumping started, in days, and } t^{\prime} \text { is the } \\
\text { time since pumping stopped (Theis, 1935; } \\
\text { Brown and others, 1963), in days. }
\end{array}
$$




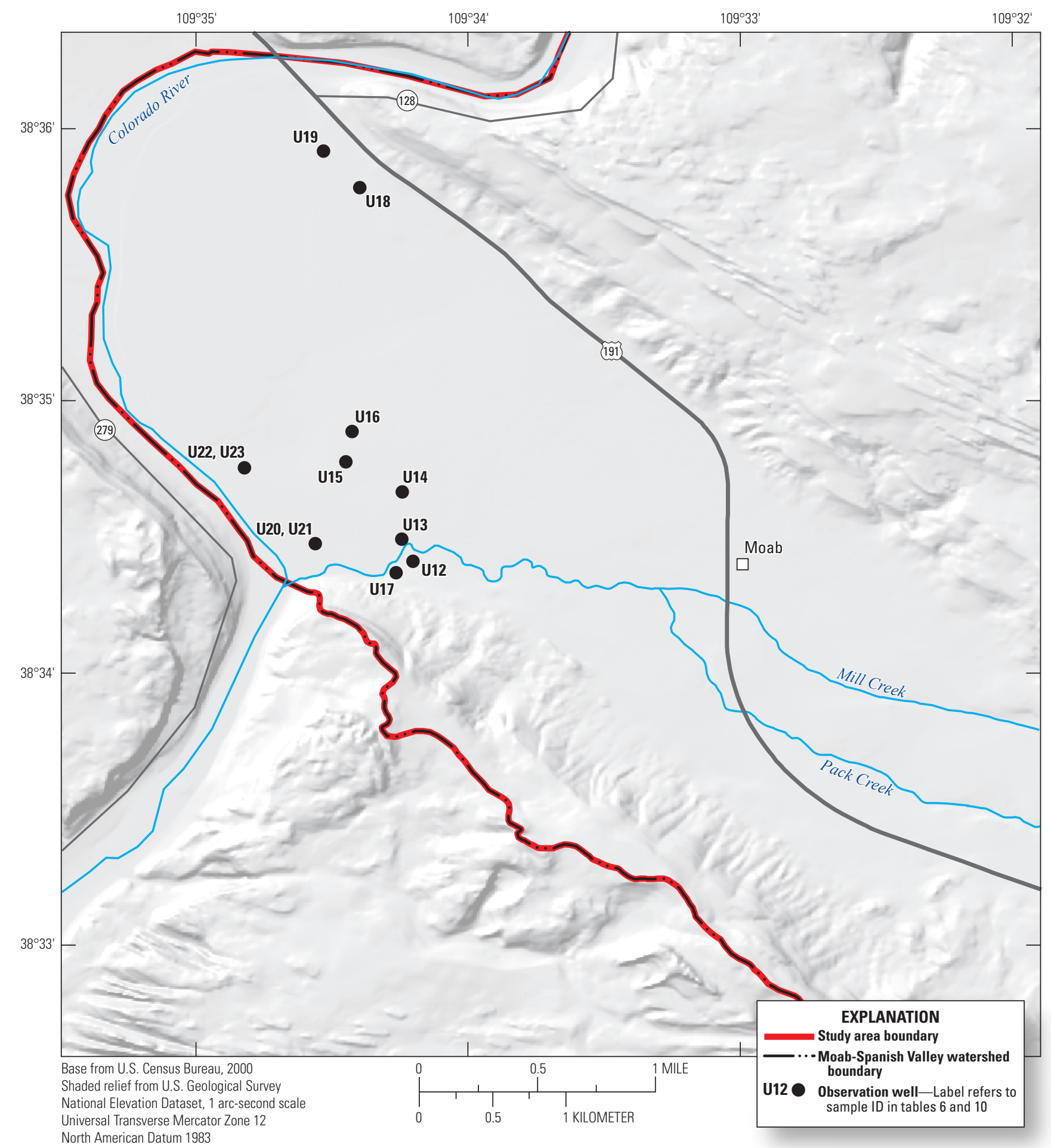

Figure 30. Locations of 12 new observation wells installed in the Matheson Wetlands Preserve, Spanish Valley study area, Utah. 


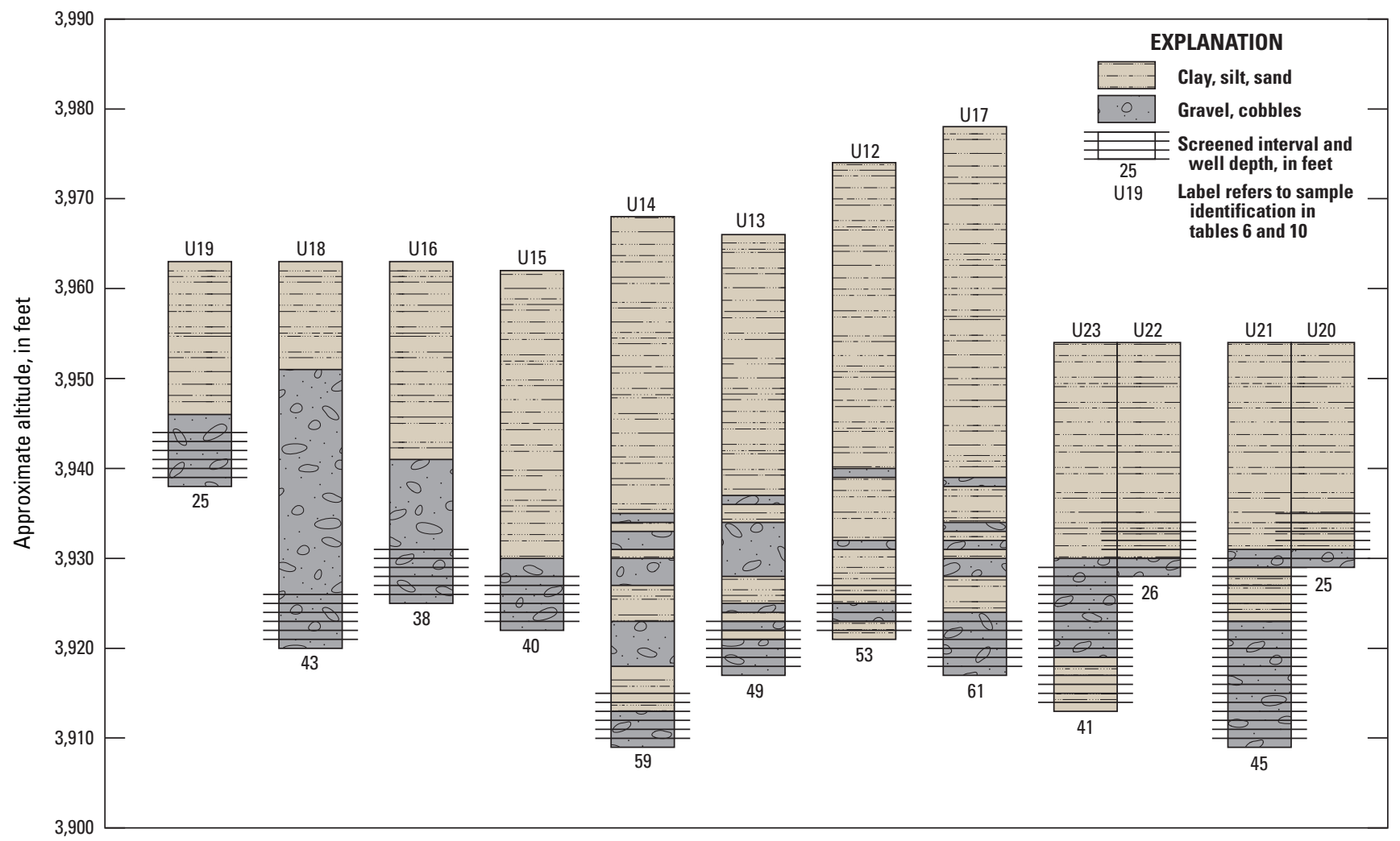

Figure 31. Lithologic logs for the new observation wells installed in the Matheson Wetlands Preserve, Spanish Valley study area, Utah.

The Cooper-Jacob method is an approximation of the Theis solution and, therefore, the assumptions remain that the aquifer is fully confined, of infinite extent, and uniform thickness; the well is fully penetrating; and the pumping rate is constant. The Cooper-Jacob approximation is valid for latetime data when pumping duration is sufficiently long, when:

$$
u=\frac{r^{2} S}{4 T t} \leq 0.01
$$

where

$$
\begin{array}{cl}
u & \text { is a dimensionless time parameter, } \\
r & \text { is the radius of the well, in } \mathrm{ft} \text {, for single- } \\
& \text { well tests, or the distance, in } \mathrm{ft} \text {, from the } \\
\text { pumping well to the observation well or } & \text { wells for multiple well tests; } \\
& \text { is the storativity, unitless (approximately } \\
\text { equal to specific yield (Sy) in an } \\
\text { unconfined aquifer and is assumed to } \\
\text { be } 0.3 \text { ); } \\
T \quad \text { is the transmissivity, in } \mathrm{ft}^{2} / \mathrm{d} \text {; and } \\
\text { is the time since pumping began (Cooper and } \\
\text { Jacob, 1946), in days. }
\end{array}
$$

Values of $u$ ranged from 0.0000008 to 0.008 , sufficiently small enough (less than 0.01 ) to justify the use of the Cooper-Jacob method.
Several assumptions of the Cooper-Jacob method were violated, namely, the aquifer was unconfined and the wells were not fully penetrating. A study by Halford and others (2006) that compared transmissivity estimates of single-well tests using Cooper-Jacob analysis to known values, however, found that more than 90 percent of the unconfined aquifer transmissivities were within a factor of 2 of the known values, and concluded that the interpretation of single-well tests with the Cooper-Jacob method remains more accurate than most alternatives.

Transmissivity was estimated from specific capacity by developing an empirical equation for the area, similar to Driscoll (1986), using the following equation from Theis (1935):

$$
T=\frac{Q}{4 \pi s_{w}} W(u)=\left[\frac{W(u)}{4 \pi}\right] \frac{Q}{s_{w}}
$$

where

$$
\begin{array}{cl}
T & \text { is the transmissivity, in } \mathrm{ft}^{2} / \mathrm{d} ; \\
Q / s_{w} & \begin{array}{l}
\text { is the specific capacity of the well (which } \\
\text { is the ratio of the pumping rate to the } \\
\text { drawdown), in } \mathrm{ft}^{2} / \mathrm{d} \text {; and }
\end{array} \\
W(u) \quad \text { is the well function (unitless). }
\end{array}
$$


The term $[W(u) / 4 \pi]$ was developed from transmissivity data produced from the other methods, resulting in the following empirical relation:

$$
T=10 \frac{Q}{S_{w}}
$$

Transmissivity estimated using the Cooper-Jacob straight-line method for drawdown data ranged from about 30 to $4,100 \mathrm{ft}^{2} / \mathrm{d}$ (table 14 and fig. 32). At two of the wells (U17 and U18), drawdown affected the pumping efficiency in such a way that water levels initially dropped significantly and then rose steadily for the remainder of the test; as a result, transmissivity could not be estimated from CooperJacob analysis of the drawdown data for these two wells. Transmissivity estimated from specific capacity ranged from about 80 to $6,200 \mathrm{ft}^{2} / \mathrm{d}$ (table 14 and fig. 32). Transmissivity estimated using the Theis recovery method ranged from about 60 to 5,900 $\mathrm{ft}^{2} / \mathrm{d}$ (table 14 and fig. 32). At well U12, the recovery data had too much noise and transmissivity could not be estimated using the Theis recovery method at this well.

Overall, average transmissivities at each aquifer test site using all available methods ranged from about 90 to $5,400 \mathrm{ft}^{2} / \mathrm{d}$, with a median of approximately $1,000 \mathrm{ft}^{2} / \mathrm{d}$ (table 14 and fig. 32). Standard deviation at each test site ranged from about 0 to $920 \mathrm{ft}^{2} / \mathrm{d}$.

\section{Estimates of Subsurface Outflow}

Two independent methods were used to estimate the amount of groundwater discharging to the Colorado River from subsurface flow through the wetlands: (1) the hydraulicgradient (or Darcy-flux) method, and (2) the age-gradient method. Both are described in the following sections.

\section{Hydraulic-Gradient (Darcy-Flux) Method}

Using Darcy's law alone, the cross-sectional area of flow is required to calculate discharge. Because the thickness of the aquifer is not well defined, flownet theory (which incorporates Darcy's law but does not require the cross-sectional area) is applied. A flownet is a two-dimensional graphical representation of groundwater flow, valid for steady-state conditions (fig. 33). A flownet is constructed of equipotential lines (water-level altitude contours), which are perpendicularly intersected by flowlines (or streamlines) for aquifers that have isotropic properties. Flowtubes are the regions between the flowlines. The flownet was constructed graphically following the rules of flownet theory (Freeze and Cherry, 1979).

Table 14. Summary of transmissivity results from aquifer tests in the Matheson Wetlands Preserve, Spanish Valley study area, Utah.

[Abbreviations: ID, identification; USGS, U.S. Geological Survey; $\mathrm{ft}^{2} / \mathrm{d}$, feet squared per day; —, no data]

\begin{tabular}{|c|c|c|c|c|c|c|}
\hline \multirow{3}{*}{ Well ID } & \multirow{3}{*}{ USGS site number } & \multicolumn{5}{|c|}{ Transmissivity (ft²/d) } \\
\hline & & \multicolumn{3}{|c|}{ Method } & \multirow[b]{2}{*}{ Average } & \multirow{2}{*}{$\begin{array}{l}\text { Standard } \\
\text { deviation }\end{array}$} \\
\hline & & $\begin{array}{l}\text { Cooper-Jacob } \\
\text { straight line }\end{array}$ & $\begin{array}{l}\text { Specific } \\
\text { capacity }\end{array}$ & $\begin{array}{c}\text { Theis } \\
\text { recovery }\end{array}$ & & \\
\hline U12 & 383424109341201 & 62 & 121 & - & 92 & 29 \\
\hline U13 & 383429109341501 & 922 & 1,317 & 1,537 & 1,258 & 254 \\
\hline U14 & 383440109341501 & 3,668 & 3,192 & 2,038 & 2,966 & 685 \\
\hline U15 & 383446109342701 & 1,743 & 1,319 & 2,178 & 1,747 & 351 \\
\hline U16 & 383453109342601 & 1,184 & 293 & 455 & 644 & 388 \\
\hline U17 & 383422109341601 & - & 83 & - & \multirow{2}{*}{188} & \multirow{2}{*}{107} \\
\hline U17 (repeat) & 383422109341601 & - & 145 & 335 & & \\
\hline U18 & 383547109342401 & - & 113 & 61 & 87 & 26 \\
\hline U19 & 383555109343201 & 270 & 632 & 1,874 & 925 & 687 \\
\hline U20 (pumped) & 383445109344902 & 34 & 306 & 644 & 328 & 249 \\
\hline U21 (observed) & 383445109344901 & 1,546 & - & 499 & 1,022 & 524 \\
\hline U22 (pumped) & 383428109343402 & 4,149 & 6,249 & 5,927 & 5,442 & 923 \\
\hline U23 (observed) & 383428109343401 & 4,149 & - & 4,149 & 4,149 & 0 \\
\hline
\end{tabular}




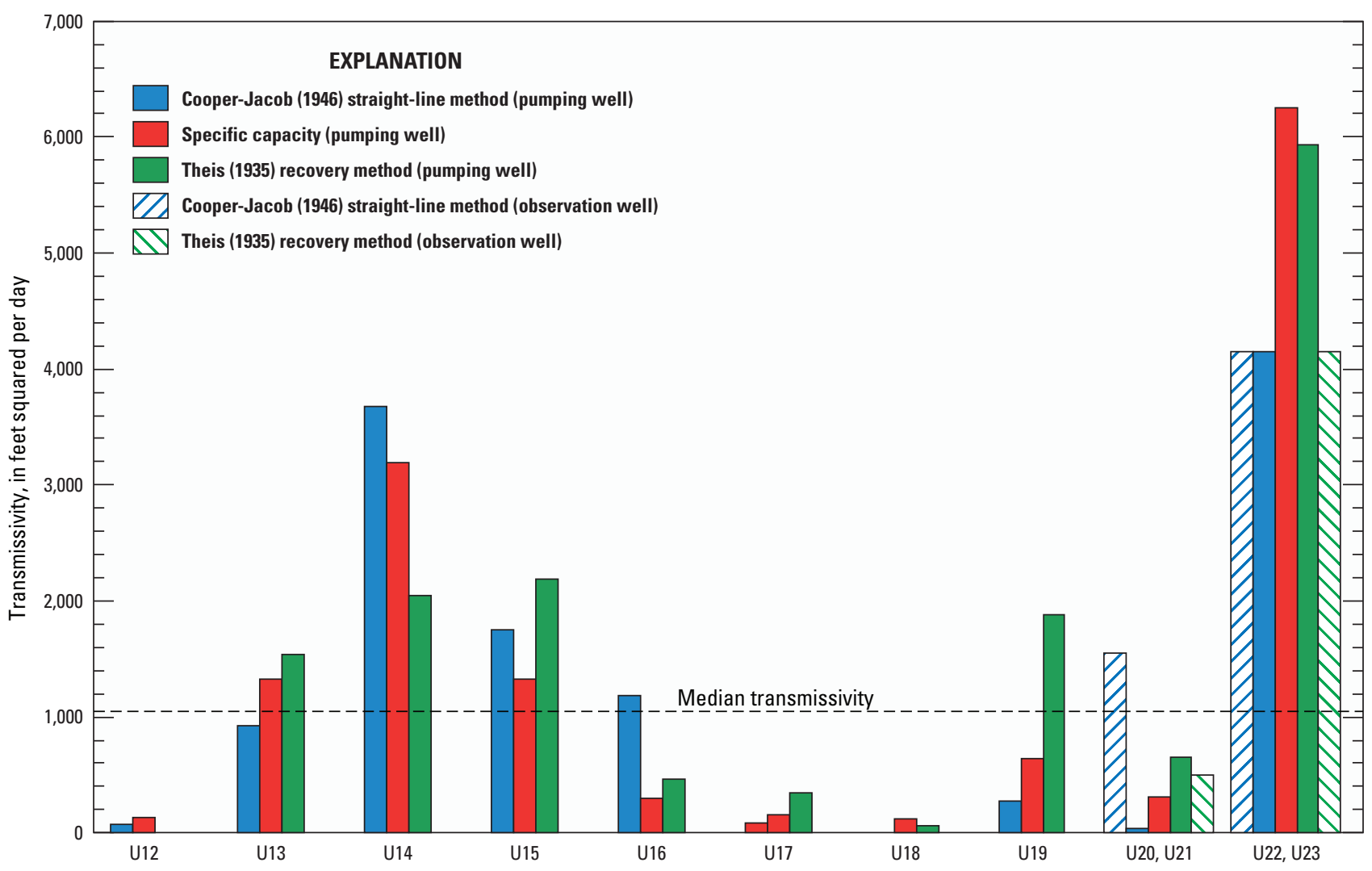

Figure 32. Transmissivity results from aquifer tests in the Matheson Wetlands Preserve, Spanish Valley study area, Utah.

According to flownet theory, the total discharge through a flownet is calculated by:

$$
Q=T \Delta H n_{\text {flowtubes }}
$$

where

$$
\begin{aligned}
& Q \text { is the total discharge through the flownet, } \\
& \text { in } \mathrm{ft}^{3} / \mathrm{d} ; \\
& T \text { is the transmissivity, in } \mathrm{ft}^{2} / \mathrm{d} ; \\
& \Delta H \text { is the water-level contour interval, in } \mathrm{ft} \text {; and } \\
& n_{\text {flowtubes }} \begin{array}{l}
\text { is the total number of flowtubes in } \\
\text { the flownet. }
\end{array}
\end{aligned}
$$

Using the median transmissivity $(T)$ of $1,000 \mathrm{ft}^{2} / \mathrm{d}$ from the aquifer tests, a water-level contour interval $(\Delta H)$ of $5 \mathrm{ft}$, and a flownet that generates eight flowtubes, the total discharge, or subsurface outflow to the Colorado River $(Q)$ is $40,000 \mathrm{ft}^{3} / \mathrm{d}$, or approximately 300 acre-ft/yr (table 11 and fig. 26).

\section{Age-Gradient Method}

Assuming piston flow, the apparent age difference between samples along the same flow path provides a direct measure of the average horizontal linear velocity between those sample sites, given by the equation:

$$
v=\frac{d}{\Delta T}
$$

where

$v \quad$ is the average horizontal linear velocity, in feet per year (ft/yr);

$d \quad$ is the distance along the flow path between sample sites, in $\mathrm{ft}$; and

$\Delta T \quad$ is the age difference between samples, in years.

Average linear velocity is related to specific discharge through porosity by:

$$
q=v n
$$

where
$q \quad$ is the specific discharge, in $\mathrm{ft} / \mathrm{yr}$;
$v$ is the average linear velocity, in $\mathrm{ft} / \mathrm{yr}$; and
$n \quad$ is the porosity, unitless. 


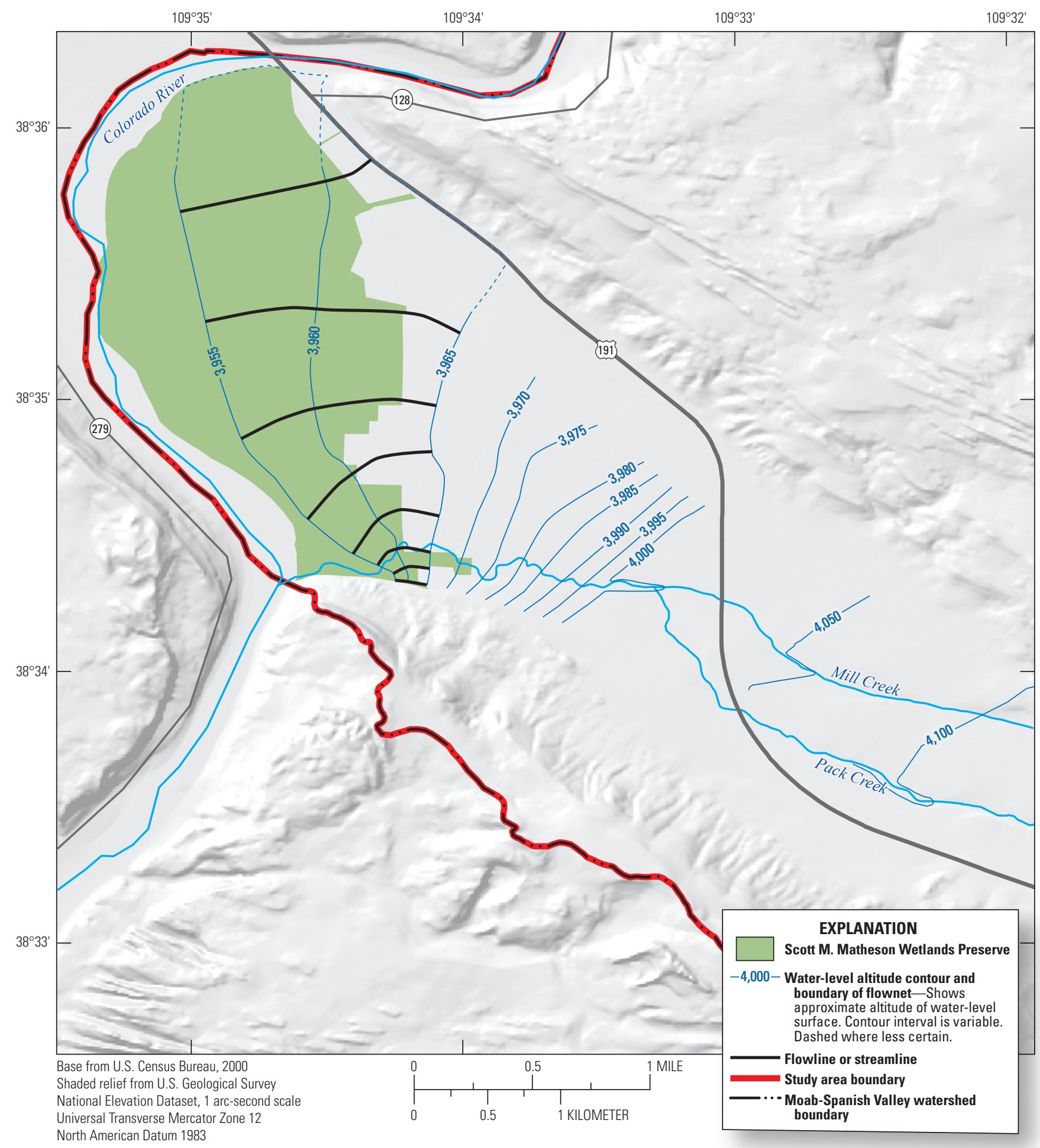

Figure 33. Flownet used to calculate discharge to the Colorado River through the Matheson Wetlands Preserve using the hydraulicgradient (Darcy-flux) method, Spanish Valley study area, Utah. 
The age difference between samples $(\Delta T)$ was determined using two "clusters" of samples, approximately $2 \mathrm{mi}$ apart (fig. 34). These samples were determined to be appropriately related because they lie along similar flow paths and have similar geochemistry. Using ${ }^{3} \mathrm{H} /{ }^{3} \mathrm{He}$ apparent ages, the age difference between the clusters was determined to be $30 \pm 14$ years. Using CFC-12 apparent ages, the age difference was determined to be $28 \pm 16$ years. The distance between the clusters was determined to be $9,000 \pm 1,500 \mathrm{ft}$. The error in the distance includes uncertainty introduced by spatial variations within a cluster of samples from which discharge was calculated.

Assuming a porosity $(n)$ of 0.3 , a typical value for polydisperse sands (Nimmo, 2004), the resulting specific discharge $(q)$ is $90 \pm 45 \mathrm{ft} / \mathrm{yr}$ using the ${ }^{3} \mathrm{H} /{ }^{3} \mathrm{He}$ apparent ages, and $96 \pm 48 \mathrm{ft} / \mathrm{yr}$ using the CFC-12 apparent ages. Assuming an aquifer width of $5,000 \mathrm{ft}$ and thickness of $100 \mathrm{ft}$, the resulting volumetric discharge estimates, or subsurface outflow to the Colorado River, are approximately 1,000 and 1,100 acre-ft/yr (table 11 and fig. 26), using the ${ }^{3} \mathrm{H} /{ }^{3} \mathrm{He}$ and CFC-12 apparent ages, respectively.

\section{Comparison to Previous Studies}

Although there have been several studies in MoabSpanish Valley since the study by Sumsion (1971), there have been no regional efforts to refine the major groundwater budget components within Moab-Spanish Valley since the 1970s. All subsequent studies that presented groundwater budgets (Eychaner, 1977; Kovacs, 2000; Lowe and others, 2007) used the budget, or a slightly modified version of the budget, and the conceptualization of flow presented in Sumsion (1971). In the current study, all components of discharge were measured or re-estimated, and using environmental tracers and other water chemistry data, sources of water to the groundwater aquifers and discharge areas in the study area were determined. There are two major differences in the conceptualization of flow in the study area and estimates of groundwater budget components between Sumsion's (1971) study and the current study. The first is the source of recharge to the VFA and the second is the estimate of subsurface outflow to the Colorado River.

The current study determined that no significant subsurface inflow from the GCGA to the VFA is occurring. This is in contrast to Sumsion's (1971) assumption that 14,000 acre-ft/yr of subsurface inflow enters the VFA from the GCGA. Although there may be some mixing of groundwater from the VFA and GCGA along the northeast margin of the valley (pl. 2), geochemical and environmental tracer data collected during the current study indicate that the primary source of recharge to the VFA is the infiltration of stream water and (or) subsurface groundwater inflow from the PCD. Furthermore, the water-level map (pl. 3) indicates that groundwater-flow directions in the VFA and GCGA generally parallel each other from the southeast to the northwest.

The 300 to 1,000 acre-ft/yr of subsurface outflow to the Colorado River estimated in the current study is much lower than Sumsion's (1971) estimate of 11,000 acre-ft/yr. Aquifer tests conducted during the current study indicate that transmissivities in the lower part of the valley are much lower than the transmissivity used by Sumsion in his Darcy-flux calculation of subsurface groundwater outflow from the valley. The total estimated discharge (and groundwater budget) from the Moab-Spanish Valley watershed (excluding Negro Bill and Ice Box Canyons) for the current study is about 13,000 to 15,000 acre-ft/yr; this is much lower than Sumsion's (1971) estimated groundwater budget of 22,000 acre-ft/yr for the same area. 


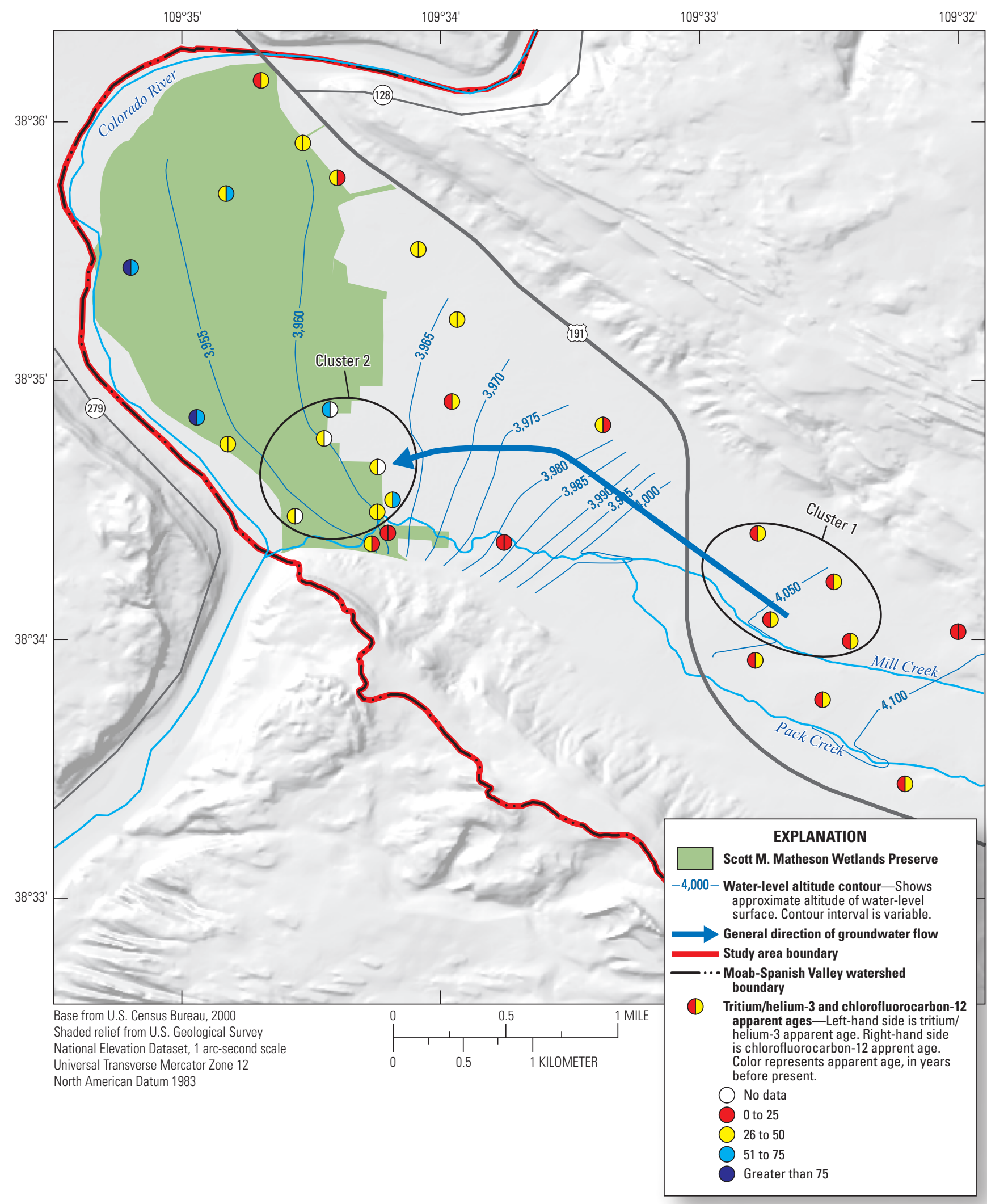

Figure 34. Tritium/helium-3 and chlorofluorocarbon-12 apparent ages from valley-fill aquifer samples and the sample clusters used to calculate discharge to the Colorado River through the Matheson Wetlands Preserve using the age-gradient method, Spanish Valley study area, Utah. 


\section{Summary}

The primary objectives of this study were to improve the understanding of the sources of recharge to, groundwater flow directions within, and discharge from both the valley-fill and Glen Canyon Group aquifers (VFA and GCGA) in Spanish Valley, Utah, and to quantify the groundwater budget of the combined VFA and GCGA. By use of various geochemical methods and classical hydrologic techniques, new insights into the groundwater-flow system were presented and the major findings are summarized here.

Based on both groundwater chemistry (stable isotopes, major ions, and noble gases) and environmental tracers in vadose-zone pore water of the Navajo Sandstone outcrop along Sand Flats Road, most recharge to the GCGA occurs high in the La Sal Mountains, and not on the sandstone outcrop area. The same groundwater chemistry evidence (stable isotopes, major ions, and noble gases) indicates that water originating in the Pack Creek drainage, rather than GCGA groundwater, is the primary source of recharge to the VFA. This is in contrast to previous studies, which assumed that the primary source of groundwater in the VFA comes from the GCGA. Groundwater recharge in the study area occurs mostly from infiltration of precipitation (in the form of snowmelt) at high altitudes. Additional recharge occurs from the infiltration of runoff along losing reaches of stream channels, or as unconsumed surface-water and groundwater irrigation. Average annual recharge to the Moab-Spanish Valley watershed part of the Spanish Valley study area was estimated to be between 9,550 and 30,000 acre-feet.

Groundwater within both the GCGA and VFA generally moves downgradient parallel to the topographic slope of the watershed towards the Colorado River. Groundwater discharge to streams and springs (measured during base flow conditions), reported discharge to springs and wells, and subsurface outflow estimates at the lower end of MoabSpanish Valley provide a more robust way to estimate the groundwater budget than evaluating recharge, which is highly uncertain. The primary discharge components in the study area from both aquifers are groundwater discharge to gaining stream reaches, groundwater discharge to springs, and well withdrawals. Based on 3 years of measurements (2014-16) and hydraulic-flux calculations at the lower end of MoabSpanish Valley, total groundwater discharge was estimated to be 14,000 to 16,000 acre-feet per year (acre-ft/yr) for the entire watershed, or 13,000 to 15,000 acre-ft/yr excluding Negro Bill and Ice Box Canyons (compared to previous estimates of 22,000 acre-ft/yr). The primary difference in the estimated groundwater discharge is this study's estimate of subsurface outflow to the Colorado River of 300 to 1,000 acre-ft/yr, compared to 11,000 acre-ft/yr estimated in previous studies. Because the study period (2014-16) experienced above average precipitation for 2 of the 3 years, the discharge estimates may be slightly higher than long-term average annual discharge from the groundwater system.

\section{References Cited}

Aeschbach-Hertig, W., Peeters, F., Beyerle, U., and Kipfer, R., 1999, Interpretation of dissolved atmospheric noble gases in natural waters: Water Resources Research, v. 35, no. 9, p. 2779-2792, accessed April 25, 2019, at https://doi.org/10.1029/1999WR900130.

Aeschbach-Hertig, W., Peeters, F., Beyerle, U., and Kipfer, R., 2000, Palaeotemperature reconstruction from noble gases in ground water taking into account equilibration with entrapped air: Nature, v. 405, p. 1040-1044, accessed April 25, 2019, at https://doi.org/10.1038/35016542.

Allison, G.B., 1988, A review of some of the physical, chemical, and isotopic techniques available for estimating groundwater recharge, in Simmers, I., ed., Estimation of natural groundwater recharge: Norwell, Mass., D. Riedel Publishers, p. 49-72, accessed May 17, 2019, at https://doi.org/10.1007/978-94-015-7780-9_4.

Allison, G.B., and Hughes, M.W., 1978, The use of environmental chloride and tritium to estimate total recharge to an unconfined aquifer: Australian Journal of Soil Resources, v. 16, no. 2, p. 181-195, accessed April 25, 2019, at https://doi.org/10.1071/SR9780181.

Allison, G.B., Gee, G.W., and Tyler, S.W., 1994, Vadose-zone techniques for estimating groundwater recharge in arid and semi-arid regions: Soil Science Society of America Journal, v. 58, no. 1, p. 6-14, accessed May 17, 2019, at https://doi.org/10.2136/sssaj1994.036159950058000100 $02 \mathrm{x}$.

Belcher, W.R., D'Agnese, F.A., and O'Brien, G.M., 2004, Introduction, chap. A of Belcher, W.R., ed., Death Valley regional ground-water flow system, Nevada and California-Hydrogeologic framework and transient ground-water flow model: U.S. Geological Survey Scientific Investigations Report 2004-5205, p. 7-19, accessed April 25, 2019, at https://doi.org/10.3133/sir20045205.

Blanchard, P.J., 1990, Ground-water conditions in the Grand County area, Utah, with emphasis on the Mill Creek-Spanish Valley area: State of Utah Department of Natural Resources Technical Publication no. 100, 69 p., 2 pls., accessed March 10, 2017, at https://www.waterrights.utah.gov/cgi-bin/docview. exe?Folder $=$ TP20-6-470\&Title $=$ Technical+Publicat ion +100 .

Busenberg, E., and L.N. Plummer, 2000, Dating young groundwater with sulfur hexafluoride: Natural and anthropogenic sources of sulfur hexafluoride: Water Resources Research, v. 36, no. 10, p. 3011-3030, accessed April 25, 2019, at https://doi.org/10.1029/2000WR900151. 
Clark, D.W., and Appel, C.L., 1985, Ground-water resources of northern Utah Valley, Utah: Utah Department of Natural Resources Technical Publication no. 80,115 p., accessed November 5, 2018, at https://waterrights.utah.gov/docSys/ v920/w920/w92000a5.pdf.

Clarke, W.B., Jenkins, W.J., and Top, Z., 1976, Determination of tritium by mass spectrometric measurement of ${ }^{3} \mathrm{He}$ : The International Journal of Applied Radiation and Isotopes, v. 27, no. 9, p. 515-522, accessed April 25, 2019, at https://doi.org/10.1016/0020-708X(76)90082-X.

Constable, S.C., Parker, R.L. and Constable, C.G., 1987, Occam's inversion-A practical algorithm for generating smooth models from electromagnetic sounding data: Geophysics, v. 52, p. 289-300, accessed April 25, 2019, at https://doi.org/10.1190/1.1442303.

Cook, P.G., Jolly, I.D., Leaney, F.W., Walker, G.R., Allan, G.L., Fifield, L.K. and Allison, G.B., 1994, Unsaturated zone tritium and chlorine-36 profiles from southern Australia: Their use as tracers of soil water movement: Water Resources Research, v. 30, no. 6, p. 1709-1719, accessed April 25, 2019, at https://doi.org/10.1029/94WR00161.

Cook, P.G., Plummer, L.N., Solomon, D.K., Busenberg, E., and Han, L.F., 2006, Effects and processes that can modify apparent CFC age, chap. 4 of Use of chlorofluorocarbons in hydrology - A guidebook: International Atomic Energy Agency, p. 31-58, accessed April 25, 2019, at http://www-pub.iaea.org/MTCD/publications/PDF/ Pub1238_web.pdf.

Cook, P.G., and Solomon, D.K., 1995, Transport of atmospheric trace gases to the water table: Implications for groundwater dating with chlorofluorocarbons and krypton 85: Water Resources Research, v. 31, no. 2, p. 263-270, accessed April 25, 2019, at https://doi.org/10.1029/94WR02232.

Cooper, H.H., and Jacob, C.E., 1946, A generalized graphical method for evaluating formation constants and summarizing well-field history: American Geophysical Union Transactions, v. 27, no. 4, p. 526-534, accessed April 25, 2019, at https://doi.org/10.1029/ TR027i004p00526.

Coplen, T.B., 1994, Reporting of stable hydrogen, carbon, and oxygen isotopic abundances: Pure and Applied Chemistry, v. 66, no. 2, p. 273-276, accessed April 25, 2019, at https://doi.org/10.1351/pac199466020273.

Craig, H., 1961a, Isotopic variations in meteoric waters: Science, v. 133 , no. 3,465, p. 1702-1703, accessed April 25, 2019, at https://doi.org/10.1126/science.133.3465.1702.
Craig, H., 1961b, Standard for reporting concentrations of deuterium and oxygen-18 in natural waters: Science, v. 133 , no. 3,467, p. 1833-1834, accessed April 25, 2019, at https://doi.org/10.1126/science.133.3467.1833.

Danielson, T.W., and Hood, J.W., 1984, Infiltration to the Navajo Sandstone in the lower Dirty Devil River basin, Utah, with emphasis on techniques used in its determination: U.S. Geological Survey Water-Resources Investigations Report 84-4154, 45 p., accessed April 25, 2019, at https://doi.org/10.3133/wri844154.

Dansgaard, W., 1964, Stable isotopes in precipitation: Tellus, v. 16, no. 4, p. 436-468, accessed April 25, 2019, at https://doi.org/10.3402/tellusa.v16i4.8993.

Davis, S.N., Whittemore, D.O., and Fabryka-Martin, J., 1998, Uses of chloride/bromide ratios in studies of potable water: Groundwater, v. 36, no. 2, p. 338-350, accessed April 25, 2019, at https://doi.org/10.1111/j.1745-6584.1998.tb01099.x.

Doelling, H.H., 2004, Geologic map of the La Sal 30’ $\times 60^{\prime}$ quadrangle, San Juan, Wayne, and Garfield Counties, Utah, and Montrose and San Miguel Counties, Colorado: Utah Geological Survey Map 205, 2 pls., scale 1:100,000, accessed March 10, 2017, at http://files.geology.utah.gov/ maps/geomap/30x60/pdf/m-205.pdf.

Doelling, H.H., Ross, M.L., and Mulvey, W.E., 2002, Geologic map of the Moab 7.5' quadrangle, Grand County, Utah: Utah Geological Survey Map 181, 2 pls., scale 1:24,000, accessed March 10, 2017, at http://files.geology.utah.gov/ maps/geomap/7_5/pdf/m-181.pdf.

Domenico, P.A., and Schwartz, F.W., 1998, Physical and chemical hydrogeology ( $2 \mathrm{~d}$ ed.): New York, John Wiley \& Sons, Inc, 506 p.

Driscoll, F.G., 1986, Groundwater and wells (2d ed.): St. Paul, Minnesota, Johnson Filtration Systems Inc., 1,089 p.

Eychaner, J.H., 1977, A digital model of groundwater flow in Spanish Valley, Grand and San Juan Counties, Utah: U.S. Geological Survey Open-File Report 77-760, 32 p., accessed April 25, 2019, at https://doi.org/10.3133/ofr77760.

Farquharson, C.G., Oldenburg, D.W., and Routh, P.S., 2003, Simultaneous 1D inversion of loop-loop electromagnetic data for magnetic susceptibility and electrical conductivity: Geophysics, v. 68, no. 6, p. 1857-1869, accessed April 25, 2019, at https://doi.org/10.1190/1.1635038.

Feltis, R.D., 1967, Ground-water conditions in Cedar Valley, Utah County, Utah: Utah Department of Natural Resources Technical Publication no. 16, 34 p., accessed May 17, 2019, at https://waterrights.utah.gov/docSys/v920/w920/ w920008e.pdf. 
Flint, A.L., and Flint, L.E., 2007, Application of the basin characterization model to estimate in-place recharge and runoff potential in the Basin and Range carbonate-rock aquifer system, White Pine County, Nevada, and adjacent areas in Nevada and Utah: U.S. Geological Survey Scientific Investigations Report 2007-5099, 20 p., accessed May 17, 2019, at https://pubs.usgs.gov/sir/2007/5099/pdf/sir20075099.pdf.

Flint, A.L., Flint, L.E., and Masbruch, M.D., 2011, Input, calibration, uncertainty, and limitations of the Basin Characterization Model, appendix 3 of Heilweil, V.M., and Brooks, L.E., eds., Conceptual model of the Great Basin carbonate and alluvial aquifer system: U.S. Geological Survey Scientific Investigations Report 2010-5193, p. 149-163, accessed April 25, 2019, at https://doi.org/10.3133/sir20105193.

Freethey, G.W., and Cordy, G.E., 1991, Geohydrology of Mesozoic rocks in the Upper Colorado River Basin in Arizona, Colorado, New Mexico, Utah, and Wyoming, excluding the San Juan Basin: U.S. Geological Survey Professional Paper 1411-C, 118 p., accessed May 17, 2019, at https://pubs.er.usgs.gov/publication/pp1411C.

Freeze, R.A., and Cherry, J.A., 1979, Groundwater: Englewood Cliffs, N.J., Prentice-Hall, 604 p.

Gardner, P.M., 2004, Environmental tracer investigation of groundwater conditions at the Scott M. Matheson Wetland Preserve near Moab, Utah: Salt Lake City, Utah, University of Utah, Master's Thesis, 160 p., accessed March 10, 2017, at http://cdmbuntu.lib.utah.edu/utils/getfile/collection/etd3/ id/1113/filename/1114.pdf.

Gardner, P.M., and Heilweil, V.M., 2014, A multiple-tracer approach to understanding regional groundwater flow in the Snake Valley area of the eastern Great Basin, USA: Applied Geochemistry, v. 45, p. 33-49, accessed April 25, 2019, at https://doi.org/10.1016/j.apgeochem.2014.02.010.

Gardner, P., and Solomon, D.K., 2009, An advanced passive diffusion sampler for the determination of dissolved gas concentrations: Water Resources Research, v. 45, no. 6, accessed April 25, 2019, at https://doi.org/10.1029/2008WR007399.

Geldon, A.L., 2003, Hydrologic properties and groundwater flow systems of the Paleozoic rocks in the Upper Colorado River Basin in Arizona, Colorado, New Mexico, Utah, and Wyoming, excluding the San Juan Basin: U.S. Geological Survey Professional Paper 1411-B, 153 p., accessed May 17, 2019, at https://pubs.er.usgs.gov/publication/pp1411B.
Halford, K.J., Weight, W.D., and Schreiber, R.P., 2006, Interpretation of transmissivity estimates from single-well pumping aquifer tests: Groundwater, v. 44, no. 3, p. 467-471, accessed April 25, 2019, at https://doi.org/10.1111/j.1745-6584.2005.00151.x.

Han, L.F., and Plummer, L.N, 2016, A review of single-sample-based models and other approaches for radiocarbon dating of dissolved inorganic carbon in groundwater: Earth-Science Reviews, v. 152, p. 119-142, accessed April 25, 2019, at https://doi.org/10.1016/j.earscirev.2015.11.004.

Han, L.F., Plummer, L.N., and Aggarwal, P., 2012, A graphical method to evaluate predominant geochemical processes occurring in groundwater systems for radiocarbon dating: Chemical Geology, v. 318-319, p. 88-112, accessed April 25, 2019, at https://doi.org/10.1016/j.chemgeo.2012.05.004.

Harnish, J., and Eisenhauer, A., 1998, Natural $\mathrm{CF}_{4}$ and $\mathrm{SF}_{6}$ on Earth: Geophysical Research Letters, v. 25, no. 13, p. 2401-2404, accessed April 25, 2019, at https://doi.org/10.1029/98GL01779.

Heilweil, V.M., Freethey, G.W., Stolp, B.J., Wilkowske, C.D., and Wilberg, D.E., 2000, Geohydrology and numerical simulation of groundwater flow in the central Virgin River basin of Iron and Washington Counties, Utah: Utah Department of Natural Resources Technical Publication 116, 139 p., accessed April 25, 2019, at https://pubs.er.usgs.gov/publication/70179116.

Heilweil, V.M., and McKinney, T.S., 2007, Net-infiltration map of the Navajo Sandstone outcrop area in western Washington County, Utah, U.S. Geological Survey Scientific Investigations Map 2988, 2 pl., accessed April 25, 2019, at https://doi.org/10.3133/sim2988.

Heilweil, V.M., McKinney, T.S., Zhdanov, M.S., and Watt, D.E., 2007, Controls on the variability of net infiltration to desert sandstone: Water Resources Research, v. 43, no. 7, W07431, accessed April 25, 2019, at https://doi.org/10.1029/2006WR005113.

Heilweil, V.M., and Solomon, D.K., 2004, Millimeter- to kilometer-scale variations in vadose-zone bedrock solutes: implications for estimating recharge in arid settings, in Hogan, J.F., Phillips, F.M., and Scanlon, B.R., eds., Groundwater recharge in a desert environment: The southwestern United States: Washington, D.C., Water Science and Applications Series, v. 9, American Geophysical Union, p. 49-67, accessed May 17, 2019, at https://agupubs.onlinelibrary.wiley.com/ doi/10.1029/009WSA04. 
Heilweil, V.M., Solomon, D.K., and Gardner, P.M., 2006, Borehole environmental tracers for evaluating net infiltration and recharge through desert bedrock: Vadose Zone Journal, v. 5, no. 1, p. 98-120, accessed April 26, 2019, at https://doi.org/10.2136/vzj2005.0002.

Hevesi, J.A., Flint, A.L., and Flint, L.E., 2003, Simulation of net infiltration and potential recharge using a distributedparameter watershed model of the Death Valley region, Nevada and California: U.S. Geological Survey Water Resources Investigations Report, 03-4090, 161 p., accessed May 17, 2019, at https://pubs.usgs.gov/wri/wri034090/.

Jobin, D.A., 1962, Relation of the transmissive character of the sedimentary rocks of the Colorado Plateau to the distribution of uranium deposits: U.S. Geological Survey Bulletin 1124, 151 p., accessed April 26, 2019, at https://doi.org/10.3133/b1124.

Johnson, C.D., Dawson, C.B., Belaval, M., and Lane, J.W., Jr., 2002, An integrated surface-geophysical investigation of the University of Connecticut landfill, Storrs, Connecticut, 2000: U.S. Geological Survey Water-Resources Investigations Report 2002-4008, 39 p., accessed April 26, 2019, at https://doi.org/10.3133/wri024008.

Jurgens, B.C., Böhlke, J.K., and Eberts, S.M., 2012, TracerLPM (Version 1): An Excel ${ }^{\circledR}$ workbook for interpreting groundwater age distributions from environmental tracer data: U.S. Geological Survey Techniques and Methods Report 4-F3, 60 p., accessed March 10, 2017, at https://doi.org/10.3133/tm4F3.

Kalin, R.M., 2000, Radiocarbon dating of groundwater systems, chap. 4 of Cook, P.G., and Herczeg A.L., eds., Environmental tracers in subsurface hydrology: Boston, Kluwer Academic Publishers, p. 111-144, accessed April 26, 2019, at https://doi.org/10.1007/978-1-4615-4557-6_4.

Kendall, C., and Coplen, T.B., 2001, Distribution of oxygen-18 and deuterium in river waters across the United States: Hydrological Processes, v. 15, no. 7, p. 1363-1393, accessed April 26, 2019, at https://doi.org/10.1002/hyp.217.

Kimball, B.A., 1992, Geochemical indicators used to determine source of saline water in Mesozoic aquifers, Montezuma Canyon area, Utah, in Subitzky, S., ed., Selected papers in the hydrologic sciences, 1988-1992: U.S. Geological Survey Water-Supply Paper 2340, p. 89-106, accessed April 26, 2019, at https://doi.org/10.3133/wsp2340.
Kipfer, R., Aeschbach-Hertig, W., Peeters, F., and Stute, M., 2002, Noble gases in lakes and ground waters, in Porcelli, D., Ballentine, C.J., and Wieler, R., eds., Reviews in mineralogy and geochemistry, v. 47: Chantilly, Virginia, Mineralogical Society of America, p. 615-700, accessed April 26, 2019, at https://doi.org/10.2138/rmg.2002.47.14.

Koh, D.C., Plummer, L.N., Busenberg, E., and Kim, Y., 2007, Evidence for terrigenic $\mathrm{SF}_{6}$ in groundwater from basaltic aquifers, Jeju Island, Korea: Implications for groundwater dating: Journal of Hydrology, v. 339, nos. 1-2, p. 93-104, accessed April 26, 2019, at https://doi.org/10.1016/j.jhydrol.2007.03.011.

Kovacs, T.R., 2000, Groundwater availability in Moab, Spanish Valley, Utah: Provo, Utah, Brigham Young University, Master's Thesis, 29 p., accessed March 10, 2017, at http:/www.riversimulator.org/Resources/farcountry/Hydrogeology/ GroundwaterAvailibilitySpanishValleyKovacsDowns2001. pdf.

Land, L., and Huff, G.F., 2009, Multi-tracer investigation of groundwater residence time in a karstic aquifer-Bitter Lakes National Wildlife Refuge, New Mexico, USA: Hydrogeology Journal, v. 18 , no. 2, p. 455-472, accessed April 26, 2019, at https://doi.org/10.1007/s10040-009-0522-3.

Lowe, M., Wallace, J., Kirby. S.M., and Bishop, C.E., 2007, The hydrogeology of Moab-Spanish Valley, Grand and San Juan Counties, Utah, with emphasis on maps for water-resource management and land-use planning: Utah Geological Survey Special Study 120, 123 p., accessed March 10, 2017, at http://ugspub.nr.utah.gov/publications/ special_studies/SS-120.pdf.

Manning, A.H., 2009, Ground-water temperature, noble gas, and carbon isotope data from the Española Basin, New Mexico: U.S. Geological Survey Scientific Investigations Report 2008-5200, 69 p., accessed April 26, 2019, at https://doi.org/10.3133/sir20085200.

Manning, A.H., 2011, Mountain-block recharge, present and past, in the eastern Española Basin, New Mexico, USA: Hydrogeology Journal, v. 19, no. 2, p. 379-397, accessed April 26, 2019, at https://doi.org/10.1007/s10040-010-0696-8.

Manning, A.H., and Solomon, D.K., 2003, Using noble gases to investigate mountainfront recharge: Journal of Hydrology, v. 275, nos. 3-4, p. 194-207, accessed April 26, 2019, at https://doi.org/10.1016/S0022-1694(03)00043-X. 
Masbruch, M.D., Chapman, D.S., and Solomon, D.K., 2012, Air, ground, and groundwater recharge temperatures in an alpine setting, Brighton Basin, Utah: Water Resources Research, v. 48, no. 10, accessed April 26, 2019, at https://doi.org/10.1029/2012WR012100.

Masbruch, M.D., Heilweil, V.M., Buto, S.G., Brooks, L.E., Susong, D.D., Flint, A.L., Flint, L.E., and Gardner, P.M., 2011, Estimated groundwater budgets, chap. D of Heilweil, V.M., and Brooks, L.E., eds., Conceptual model of the Great Basin carbonate and alluvial aquifer system: U.S. Geological Survey Scientific Investigations Report 2010-5193, p. 73-125, accessed April 26, 2019, at https://doi.org/10.3133/sir20105193.

Mazor, E., and Bosch, A., 1992, Helium as a semi-quantitative tool for groundwater dating in the range of $10^{4}$ to $10^{8}$ years, in Isotopes of noble gases as tracers in environmental studies: Proceedings of a consultants meeting on isotopes of noble gases as tracers in environmental studies organized by the International Atomic Energy Agency, Vienna, May 29 to June 2, 1989, Vienna, International Atomic Energy Agency, p. 163-178, accessed May 17, 2019, at https://inis.iaea.org/ search/search.aspx?orig_q=RN:23057715.

McCoy, J., Johnston, K., Kopp, S., Borup, B., and Willison, J., 2001, Using ArcGIS ${ }^{\mathrm{TM}}$ Spatial Analyst: Redlands, California, Environmental Systems Research Institute, 232 p., accessed May 17, 2019, at http://downloads2.esri.com/support/documentation/ao_/ Using_ArcGIS_Spatial_Analyst.pdf.

Michel, R.L., 1989, Tritium deposition over the continental United States, 1953-1983, in Delleur, J.W., ed., Atmospheric deposition: United Kingdom, International Association of Hydrological Sciences Publication, no. 179, p. 109-115, accessed May 17, 2019, at http://hydrologie.org/redbooks/a179/iahs_179_0109.pdf.

Naftz, D.L., Peterman, Z.E., and Spangler, L.E., 1997, Using $\delta^{87} \mathrm{Sr}$ values to identify sources of salinity to a freshwater aquifer, Greater Aneth Oil Field, Utah, USA: Chemical Geology, v. 141, nos. 3-4, p. 195-209, accessed April 26, 2019, at https://doi.org/10.1016/S0009-2541(97)00063-6.

National Atmospheric Deposition Program, 2016, Total deposition 2015 annual map summary: Champaign, Illinois, University of Illinois at Urbana-Champaign, Illinois State Water Survey, NADP Data Report 2016-02, 20 p., accessed May 17, 2019, at http://nadp.slh.wisc.edu/committees/tdep/ reports/TDEPreport15_Final.pdf.

National Center for Earth Resources Observation and Science, 1999, National Elevation Dataset: U.S. Geological Survey, accessed April 2005, at http://ned.usgs.gov/.
Nelson, N.C., 2017, Quantifying groundwater discharge from the valley-fill aquifer in Moab-Spanish Valley near Moab, Utah: Salt Lake City, Utah, University of Utah, Master's Thesis, $79 \mathrm{p}$.

Ong, J.B., Lane, J.W., Jr., Zlotnik, V.A., Halihan, T., and White, E.A., 2010, Combined use of frequency-domain electromagnetic and electrical resistivity surveys to delineate near-lake groundwater flow in the semi-arid Nebraska Sand Hills, USA, Hydrogeology Journal, v. 18, no. 6, p. 1539-1545, accessed April 26, 2019, at https://doi.org/10.1007/s10040-010-0617-x.

Plummer, L.N., and Busenberg, E., 2000, Chlorofluorocarbons, chap. 15 of Cook, P.G., and Herczeg A.L., eds., Environmental tracers in subsurface hydrology: Boston, Mass., Kluwer Academic Publishers, p. 441-478.

Rush, F.E., Whitfield, M.S., and Hart, I.M., 1982, Regional hydrology of the Green River-Moab area, northwestern Paradox Basin, Utah: U.S. Geological Survey OpenFile Report 82-107, 86 p., accessed April 26, 2019, at https://doi.org/10.3133/ofr82107.

San Juan, C.A., Belcher, W.R., Laczniak, R.J., and Putnam, H.M., 2004, Hydrologic components for model development, chap. C of Belcher, W.R., ed., Death Valley regional ground-water flow system, Nevada and California-Hydrogeologic framework and transient ground-water flow model: U.S. Geological Survey Scientific Investigations Report 2004-5205, p. 103-136, accessed April 26, 2019, at https://doi.org/10.3133/sir20045205.

Sanford, W.E., Shropshire, R.G., and Solomon, D.K., 1996, Dissolved gas tracers in groundwater-Simplified injection, sampling, and analysis: Water Resources Research, v. 32, no. 6, p. 1635-1642, accessed April 26, 2019, at https://doi.org/10.1029/96WR00599.

Solomon, D.K., 2000, ${ }^{4} \mathrm{He}$ in groundwater, chap. 14 of Cook, P.G., and Herczeg A.L., eds., Environmental tracers in subsurface hydrology: Boston, Mass., Kluwer Academic Publishers, p. 425-440.

Solomon, D.K., and Cook, P.G., 2000, ${ }^{3} \mathrm{H}$ and ${ }^{3} \mathrm{He}$, chap. 13 of Cook, P.G., and Herczeg A.L., eds., Environmental tracers in subsurface hydrology: Boston, Mass., Kluwer Academic Publishers, p. 397-424.

Spatial Climate Analysis Service, 2004, Parameter-Elevation Regressions on Independent Slopes Model (PRISM): Oregon State University, accessed August 29, 2007, at http://prism.oregonstate.edu/. 
Steiger, J.I., and Susong, D.D., 1997, Recharge areas and quality of ground water for the Glen Canyon and valley-fill aquifers, Spanish Valley area, Grand and San Juan Counties, Utah: U.S. Geological Survey WaterResources Investigations Report 97-4206, 2 pls., accessed April 26, 2019, at https://doi.org/10.3133/wri974206.

Stolp, B.J., 1994, Hydrology and potential for groundwater development in southeastern Tooele Valley and adjacent areas in the Oquirrh Mountains, Tooele County, Utah: Utah Department of Natural Resources Technical Publication no. 107, 67 p., accessed November 5, 2018, at https://www.waterrights.utah.gov/cgi-bin/docview. exe?Folder $=$ TP20-6-561\&Title $=$ Technical + Publicat ion +107 .

Stonestrom, D.A., Prudic, D.E., Laczniak, R.J., Akstin, K.C., Boyd, R.A., and Henkelman, K.K., 2003, Estimates of deep percolation beneath native vegetation, irrigated fields, and the Amargosa River channel, Amargosa Desert, Nye County, Nevada: U.S. Geological Survey OpenFile Report 2003-104, 83 p., accessed April 26, 2019, at https://doi.org/10.3133/ofr03104.

Stute, M., and Schlosser, P., 2000, Atmospheric noble gases, chap. 11 of Cook, P.G., Herczeg, A.L., eds., Environmental tracers in subsurface hydrology: Boston, Mass., Kluwer Academic Publishers, p. 349-377.

Sumsion, C.T., 1971, Geology and water resources of the Spanish Valley area, Grand and San Juan Counties, Utah: State of Utah Department of Natural Resources Technical Publication no. 32, 45 p., 3 pls., accessed March 10, 2017, at https://www.waterrights.utah.gov/cgi-bin/docview. exe?Folder=TP20-4-690\&Title=Technical + Publication +32 .

Susong, D.D., 1995, Water budget and simulation of one-dimensional unsaturated flow for a floodand sprinkler-irrigated field near Milford, Utah: U.S. Geological Survey Water-Resources Investigations Report 95-4072, 32 p., accessed April 26, 2019, at https://doi.org/10.3133/wri954072.

Tarboton, D.G., 1997, A new method for the determination of flow directions and upslope areas in grid digital elevation models: Water Resources Research, v. 33, no. 2, p. 309-319, accessed April 26, 2019, at https://doi.org/10.1029/96WR03137.
Theis, C.V., 1935, The relation between the lowering of the piezometric surface and the rate and duration of discharge of a well using ground-water storage: Eos, Transactions American Gophysical Union, v. 16, no. 2, p. 519-524, accessed April 26, 2019, at https://doi.org/10.1029/TR016i002p00519.

U.S. Census Bureau, 2010, 2010 Census Summary File 1, accessed March 10, 2017, at https://factfinder.census.gov/ faces/nav/jsf/pages/index.xhtml.

U.S. Department of Agriculture, Natural Resources Conservation Service, 2018, Web soil survey: accessed May 24, 2018, at https://websoilsurvey.nrcs.usda.gov.

U.S. Environmental Protection Agency, 2018, 2018 edition of the drinking water standards and health advisories tables, accessed July 22, 2019, at https://www.epa.gov/sites/ production/files/2018-03/documents/dwtable2018.pdf.

Ward, S.H., and Hohmann, G.W., 1988, Electromagnetic theory for geophysical applications, in Nabighian, M.N., ed., Electromagnetic methods in applied geophysics: Tulsa, Oklahoma, Society of Exploration Geophysicists, p. 131-312.

Welch, A.H., and Preissler, A.M., 1986, Aqueous geochemistry of the Bradys Hot Springs geothermal area Churchill County Nevada, in Subitzky, S. ed., Selected papers in the hydrologic sciences: U.S. Geological Survey WaterSupply Paper 2290, p. 17-36, accessed April 26, 2019, at https://doi.org/10.3133/wsp2290.

Wilde, F.D., and Radtke, D.B., 1998, Field measurements: U.S. Geological Survey Techniques of Water-Resources Investigations, book 9, chap. A6, variously paged, accessed April 26, 2019, at https://water.usgs.gov/owq/FieldManual/ Chapter6/Ch6_contents.html.

Wood, W.W., and Sanford, W.E., 1995, Chemical and isotopic methods for quantifying ground-water recharge in a regional, semi-arid environment: Groundwater, v. 33, no. 3, p. 458-468, accessed April 26, 2019, at https://doi.org/10.1111/j.1745-6584.1995.tb00302.x. 


\section{Appendix 1. Data Tables}

Table 1-1. Selected attributes of groundwater, spring, and surface-water sites sampled in the Spanish Valley study area, Utah.

[Sample ID: identifier used in tables and figures in the report. Horizontal coordinate information is referenced to the North American Datum of 1983 (NAD83). Abbreviations: ID, identification; U.S. Geological Survey; SP, spring; GW, groundwater (well); ST, stream; N/A, not applicable; —, no data]

\begin{tabular}{|c|c|c|c|c|c|c|c|}
\hline $\begin{array}{l}\text { Sample } \\
\text { ID }\end{array}$ & USGS site ID & USGS site name & $\begin{array}{l}\text { Site } \\
\text { type }\end{array}$ & $\begin{array}{l}\text { Latitude } \\
\text { (decimal } \\
\text { degrees) }\end{array}$ & $\begin{array}{l}\text { Longitude } \\
\text { (decimal } \\
\text { degrees) }\end{array}$ & $\begin{array}{c}\text { Altitude of land } \\
\text { surface or gage } \\
\text { (feet) }\end{array}$ & $\begin{array}{l}\text { Well } \\
\text { depth } \\
\text { (feet) }\end{array}$ \\
\hline 1 & 383545109335701 & (D-25-21)26dca-S1 & SP & 38.59580556 & -109.5658056 & $4,057.00$ & N/A \\
\hline 2 & 383238109302501 & (D-26-22)17add- 1 & GW & 38.5438611 & -109.5076111 & $4,360.00$ & - \\
\hline 3 & 383148109292201 & (D-26-22)22bda-S1 & SP & 38.52991667 & -109.4894167 & $4,484.00$ & N/A \\
\hline 4 & 383224109284701 & (D-26-22)15daa- 2 & GW & 38.54002778 & -109.4806111 & $4,673.00$ & 300 \\
\hline 6 & 383149109284601 & (D-26-22)22aad-S1 & SP & 38.53044444 & -109.4802222 & $4,571.00$ & N/A \\
\hline 7 & 383312109322701 & (D-26-22) 7ccb-S1 & SP & 38.55344444 & -109.5408611 & $4,209.00$ & N/A \\
\hline 8 & 383312109263501 & (D-26-22)12dad-S1 & SP & 38.5534722 & -109.4430278 & $4,907.00$ & N/A \\
\hline 9 & 383457109245401 & (D-25-23)31dcb-S1 & SP & 38.582 & -109.4155556 & $5,897.00$ & N/A \\
\hline 13 & 382849109255901 & (D-27-23) 6cad- 1 & GW & 38.48025 & -109.4331667 & $5,023.00$ & 365 \\
\hline 14 & 383026109200301 & (D-26-23)25ddb-S1 & SP & 38.5072222 & -109.3340278 & $7,909.00$ & N/A \\
\hline 15 & 383308109224601 & (D-26-23)10cda- 1 & GW & 38.5522222 & -109.3793056 & $6,981.00$ & 1,030 \\
\hline 16 & 382621109214001 & (D-27-23)23cab- 1 Pack Creek Well No. 1 & GW & 38.4393889 & -109.358778 & $6,104.00$ & 84 \\
\hline 17 & 382929109272101 & $(\mathrm{D}-26-22) 36 \mathrm{ccd}-1$ & GW & 38.49141667 & -109.4557222 & $4,823.00$ & 284 \\
\hline 18 & 383024109283801 & $(\mathrm{D}-26-22) 26 \mathrm{ccc}-2$ & GW & 38.50655556 & -109.4772778 & $4,683.00$ & 284 \\
\hline 19 & 383537109303001 & (D-25-22)32abb-S1 & SP & 38.59351667 & -109.5084694 & $4,323.00$ & N/A \\
\hline 20 & 382959109182501 & $\begin{array}{l}\text { MILL CREEK AT LA SAL MOUNTAIN } \\
\text { LOOP ROAD BRIDGE }\end{array}$ & ST & 38.49981389 & -109.3069583 & $7,669.00$ & N/A \\
\hline $\mathrm{U} 3$ & 383514109335601 & (D-25-21)35adc- 1 & GW & 38.58725 & -109.5656111 & $3,972.54$ & 80 \\
\hline U4 & 383432109341101 & (D-26-21) 2acb- 1 & GW & 38.5756111 & -109.5697778 & $3,970.81$ & 68 \\
\hline U5 & 383454109335701 & (D-25-21)35dca- 4 & GW & 38.58194444 & -109.5659444 & $3,979.36$ & 50 \\
\hline U6 & 383422109334501 & (D-26-21) 2add- 1 & GW & 38.57288889 & -109.5625833 & $3,988.77$ & 93 \\
\hline U7 & 383345109323101 & (D-26-22) 7bbc- 1 & GW & 38.5627222 & -109.5420556 & $4,103.07$ & 119 \\
\hline U8 & 383413109322801 & (D-26-22) 6cbb- 4 & GW & 38.57027778 & -109.5411111 & $4,080.00$ & 52 \\
\hline U9 & 383326109321201 & (D-26-22) 7cab- 3 & GW & 38.55727778 & -109.5366944 & $4,154.79$ & 80 \\
\hline U10 & 383424109324601 & (D-26-21) 1adc- 1 & GW & 38.5733333 & -109.5461111 & $4,046.00$ & 300 \\
\hline U11 & 383405109324201 & (D-26-21) 1 ddb- 1 & GW & 38.56788889 & -109.5453889 & $4,066.12$ & 28 \\
\hline U12 & 383424109341201 & (D-26-21) 2acc- 1 & GW & 38.5734722 & -109.5700556 & $3,967.78$ & 53 \\
\hline U13 & 383429109341501 & (D-26-21) 2bda- 1 & GW & 38.5748333 & -109.57075 & $3,965.72$ & 49 \\
\hline U14 & 383440109341501 & (D-26-21) 2baa- 1 & GW & 38.57775 & -109.5707222 & $3,965.46$ & 59 \\
\hline
\end{tabular}


Table 1-1. Selected attributes of groundwater, spring, and surface-water sites sampled in the Spanish Valley study area, Utah.-Continued

[Sample ID: identifier used in tables and figures in the report. Horizontal coordinate information is referenced to the North American Datum of 1983 (NAD83). Abbreviations: ID, identification; U.S. Geological Survey; SP, spring; GW, groundwater (well); ST, stream; N/A, not applicable; - , no data]

\begin{tabular}{|c|c|c|c|c|c|c|c|}
\hline $\begin{array}{l}\text { Sample } \\
\text { ID }\end{array}$ & USGS site ID & USGS site name & $\begin{array}{l}\text { Site } \\
\text { type }\end{array}$ & $\begin{array}{l}\text { Latitude } \\
\text { (decimal } \\
\text { degrees) }\end{array}$ & $\begin{array}{l}\text { Longitude } \\
\text { (decimal } \\
\text { degrees) }\end{array}$ & $\begin{array}{l}\text { Altitude of land } \\
\text { surface or gage } \\
\text { (feet) }\end{array}$ & $\begin{array}{l}\text { Well } \\
\text { depth } \\
\text { (feet) }\end{array}$ \\
\hline U15 & 383446109342701 & (D-25-21)35cdc- 1 & GW & 38.5795833 & -109.5741667 & $3,962.00$ & 40 \\
\hline U16 & 383453109342601 & (D-25-21)35cdb- 1 & GW & 38.58141667 & -109.5738056 & $3,962.87$ & 38 \\
\hline U17 & 383422109341601 & (D-26-21) 2bdd- 1 & GW & 38.57277778 & -109.5711111 & $3,967.04$ & 61 \\
\hline U18 & 383547109342401 & (D-25-21)26cdb- 1 & GW & 38.59638889 & -109.5733333 & $3,962.10$ & 43 \\
\hline U19 & 383555109343201 & (D-25-21)26cbd- 1 & GW & 38.5986111 & -109.5755556 & $3,964.07$ & 25 \\
\hline U20 & 383445109344902 & (D-26-21) 3aL1- 2 & GW & 38.57919444 & -109.5803889 & $3,965.04$ & 25 \\
\hline U22 & 383428109343402 & (D-26-21) 2bca- 2 & GW & 38.5745833 & -109.5760556 & $3,963.63$ & 26 \\
\hline U24 & 383530109340501 & (D-25-21)35abc- 2 & $\mathrm{GW}$ & 38.59175 & -109.5681111 & $3,975.82$ & 45 \\
\hline U25 & 383359109322501 & (D-26-22) 6ccd- 2 & GW & 38.5665 & -109.54025 & $4,101.06$ & 68 \\
\hline U26 & 383359109315701 & (D-26-22) 6dcc- 1 & GW & 38.56627778 & -109.5325278 & $4,173.98$ & - \\
\hline U27 & 383609109344101 & (D-25-21)26bcc- 1 & GW & 38.60263889 & -109.5782778 & $3,972.55$ & 74 \\
\hline $\mathrm{U} 28$ & 383543109344901 & (D-25-21)27ddd- 1 & GW & 38.5952222 & -109.5805833 & $3,965.81$ & 53.6 \\
\hline U29 & 383526109351101 & (D-25-21)34abc- 1 & GW & 38.5905833 & -109.5866944 & $3,965.93$ & 56 \\
\hline U30 & 383451109345601 & (D-25-21)34ddc- 1 & GW & 38.5809722 & -109.5824722 & $3,963.08$ & 32 \\
\hline U31 & 383451109345602 & (D-25-21)34ddc- 2 & GW & 38.5809722 & -109.5824722 & $3,963.08$ & 48.1 \\
\hline U32 & 383451109345603 & (D-25-21)34ddc- 3 & GW & 38.5809722 & -109.5824722 & $3,963.08$ & 100.6 \\
\hline- & 09183500 & $\begin{array}{l}\text { MILL CREEK AT SHELEY TUNNEL, } \\
\text { NEAR MOAB, UT }\end{array}$ & ST & 38.4830403 & -109.4040043 & $5,504.00$ & N/A \\
\hline- & 09183600 & $\begin{array}{l}\text { MILL CREEK BELOW SHELEY } \\
\text { TUNNEL, NEAR MOAB, UT }\end{array}$ & ST & 38.48571796 & -109.4111044 & $5,345.00$ & N/A \\
\hline- & 382928109271401 & $\begin{array}{l}\text { PACK CREEK, TANK AT WEST ALLEN } \\
\text { STREET }\end{array}$ & ST & 38.49108889 & -109.4539806 & $4,837.00$ & N/A \\
\hline- & 383159109274001 & $\begin{array}{l}\text { MILL CREEK NR MOAB AREA } \\
\text { WATERSHED PARTNERSHIP SITE }\end{array}$ & ST & 38.53316389 & -109.4611444 & $4,731.00$ & N/A \\
\hline- & 383232109281501 & $\begin{array}{l}\text { MILL CREEK ABOVE SPRING } \\
\text { CANYON CREEK }\end{array}$ & ST & 38.5422111 & -109.4707 & $4,627.00$ & N/A \\
\hline- & 383240109281801 & $\begin{array}{l}\text { SPRING CANYON CREEK ABV MILL } \\
\text { CREEK IN HIDDEN VAL }\end{array}$ & ST & 38.5445 & -109.4715611 & $4,606.00$ & N/A \\
\hline- & 383347109302401 & $\begin{array}{l}\text { MILL CREEK ABOVE NORTH FORK } \\
\text { NEAR MOAB, UT }\end{array}$ & ST & 38.56308889 & -109.5067 & $4,282.00$ & N/A \\
\hline- & 383351109302101 & $\begin{array}{l}\text { NORTH FORK MILL CREEK NEAR } \\
\text { MOAB, UT }\end{array}$ & ST & 38.56414167 & -109.5058028 & $4,293.00$ & N/A \\
\hline- & 383418109331001 & Mill Creek above Pack Creek & ST & 38.57177778 & -109.5528333 & $4,010.00$ & $\mathrm{~N} / \mathrm{A}$ \\
\hline- & 383419109333101 & $\begin{array}{l}\text { MILL CREEK BL PACK CREEK AT } \\
\text { MOAB, UT }\end{array}$ & ST & 38.57194444 & -109.5586111 & $4,010.00$ & N/A \\
\hline- & 383424109341701 & $\begin{array}{l}\text { MILL CREEK AT MATHESON } \\
\text { WETLANDS NR MOAB, UT }\end{array}$ & ST & 38.5733333 & -109.5713889 & $3,960.00$ & N/A \\
\hline- & 383424109343201 & $\begin{array}{l}\text { MILL CREEK ABOVE CONFLUENCE } \\
\text { WITH COLORADO RIVER }\end{array}$ & ST & 38.5733333 & -109.5754444 & $3,963.00$ & N/A \\
\hline- & 383626109322401 & $\begin{array}{l}\text { UNNAMED CANYON SW OF NEGRO } \\
\text { BILL CANYON }\end{array}$ & ST & 38.60716667 & -109.5398611 & $3,975.00$ & N/A \\
\hline - & 383634109315901 & Negro Bill Canyon abv Colorado River & ST & 38.60938889 & -109.5329444 & $3,974.00$ & N/A \\
\hline
\end{tabular}


Table 1-2. Selected attributes of wells and water levels used in constructing the water-level surface map for the Spanish Valley study area, Utah.

[Data is from the U.S. Geological Survey's National Water Information System (NWIS) database. Horizontal coordinate information is referenced to the North American Datum of 1983 (NAD 83). Abbreviations: USGS, U.S. Geological Survey; —, no data]

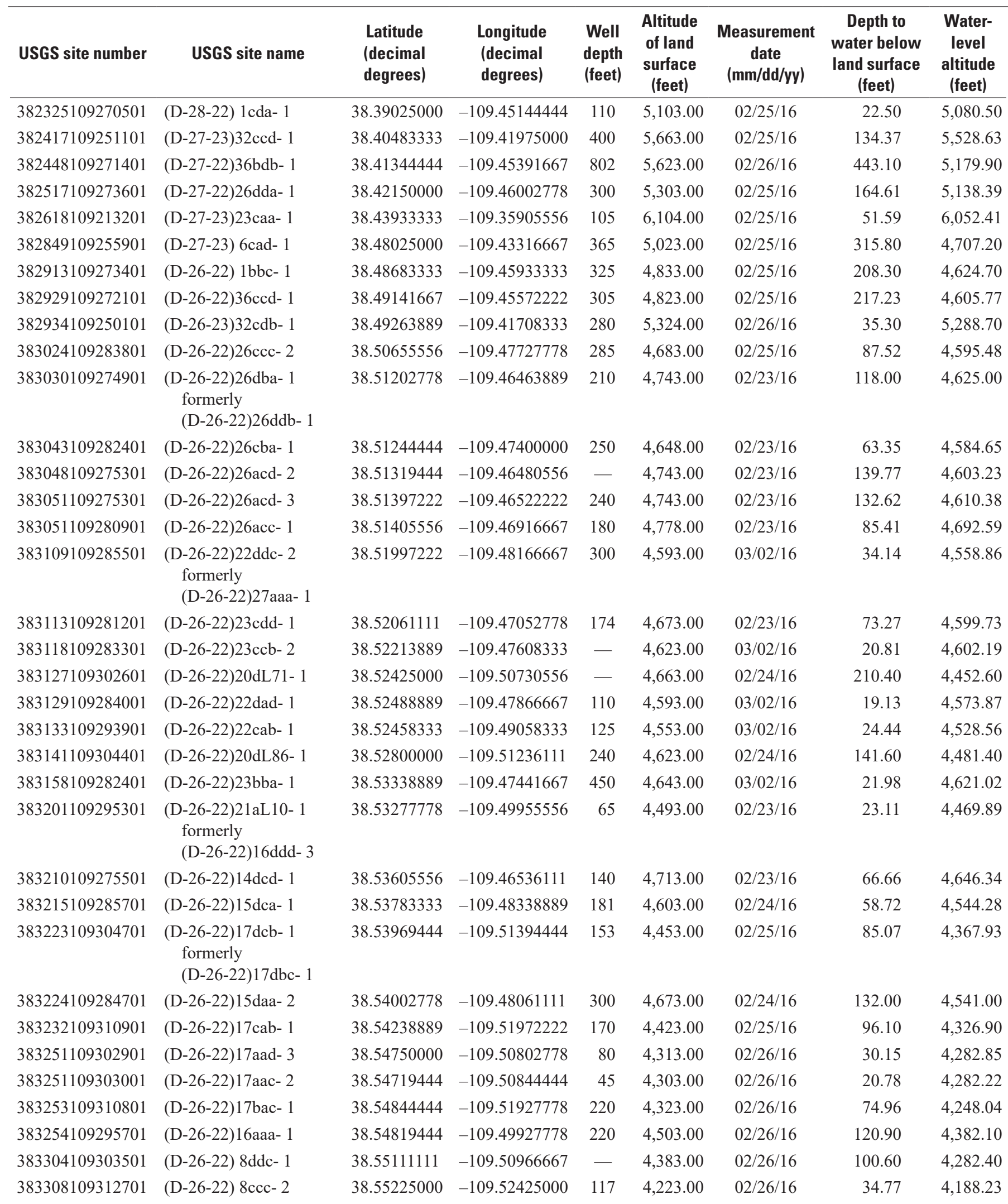


Table 1-2. Selected attributes of wells and water levels used in constructing the water-level surface map for the Spanish Valley study area, Utah.-Continued

[Data is from the U.S. Geological Survey's National Water Information System (NWIS) database. Horizontal coordinate information is referenced to the North American Datum of 1983 (NAD 83). Abbreviations: USGS, U.S. Geological Survey; -, no data]

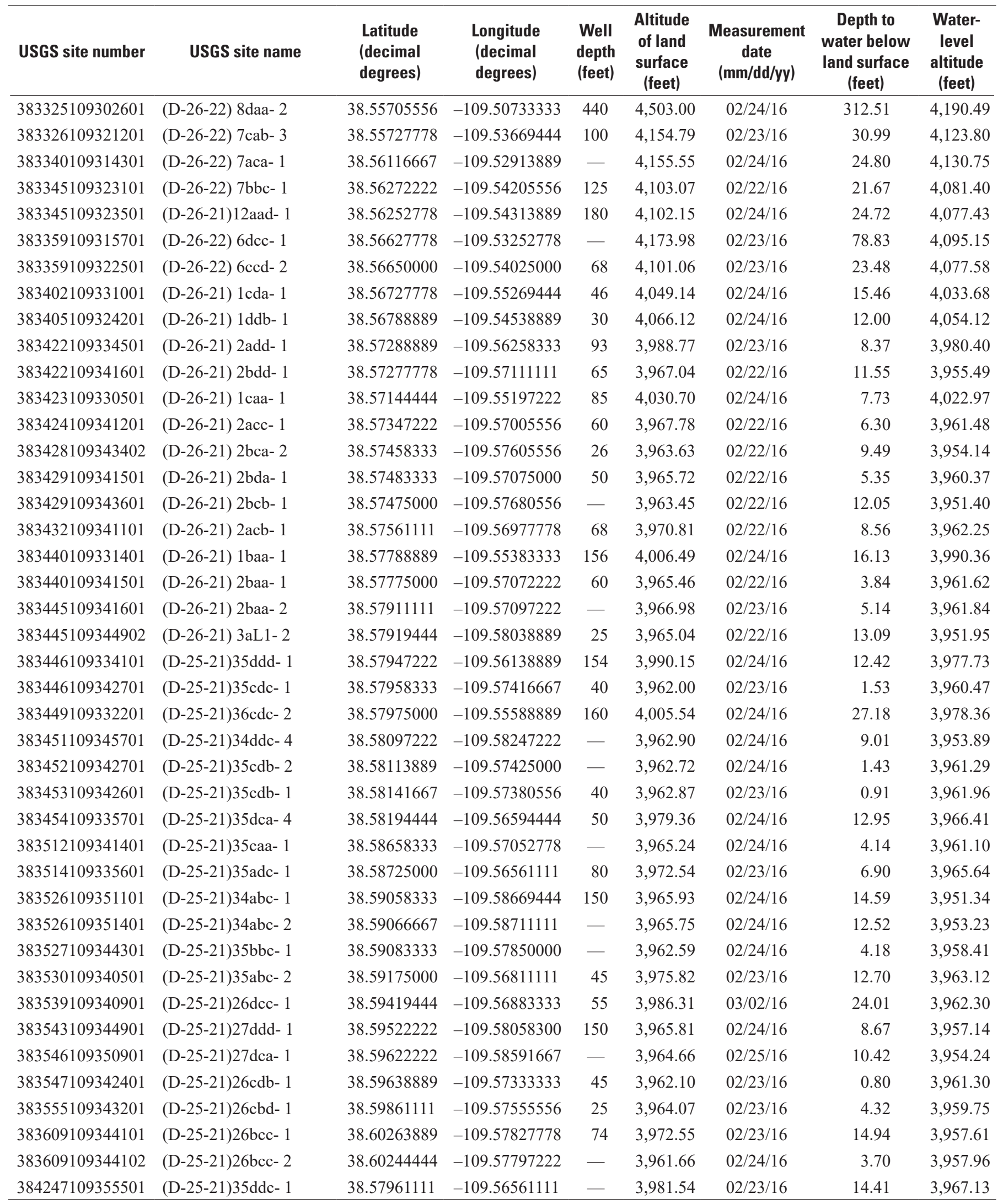


For more information concerning the research in this report, contact the Director, Utah Water Science Center

U.S. Geological Survey

2329 Orton Circle

Salt Lake City, Utah 84119

https://ut.water.usgs.gov

Publishing support provided by the U.S. Geological Survey Science Publishing Network, Sacramento Publishing Service Center 


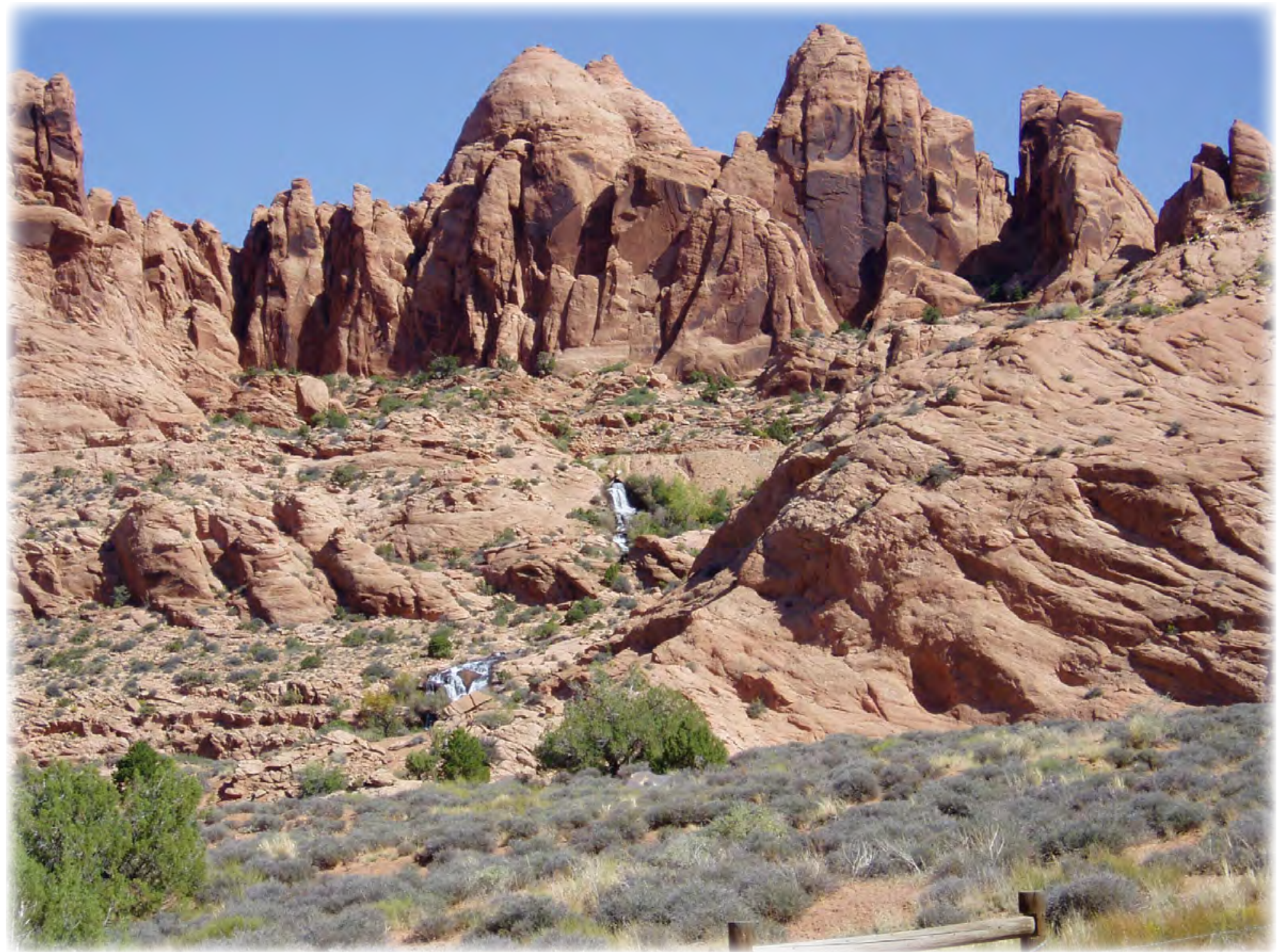

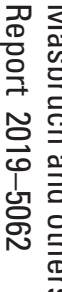

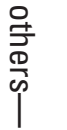

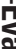

핳. 